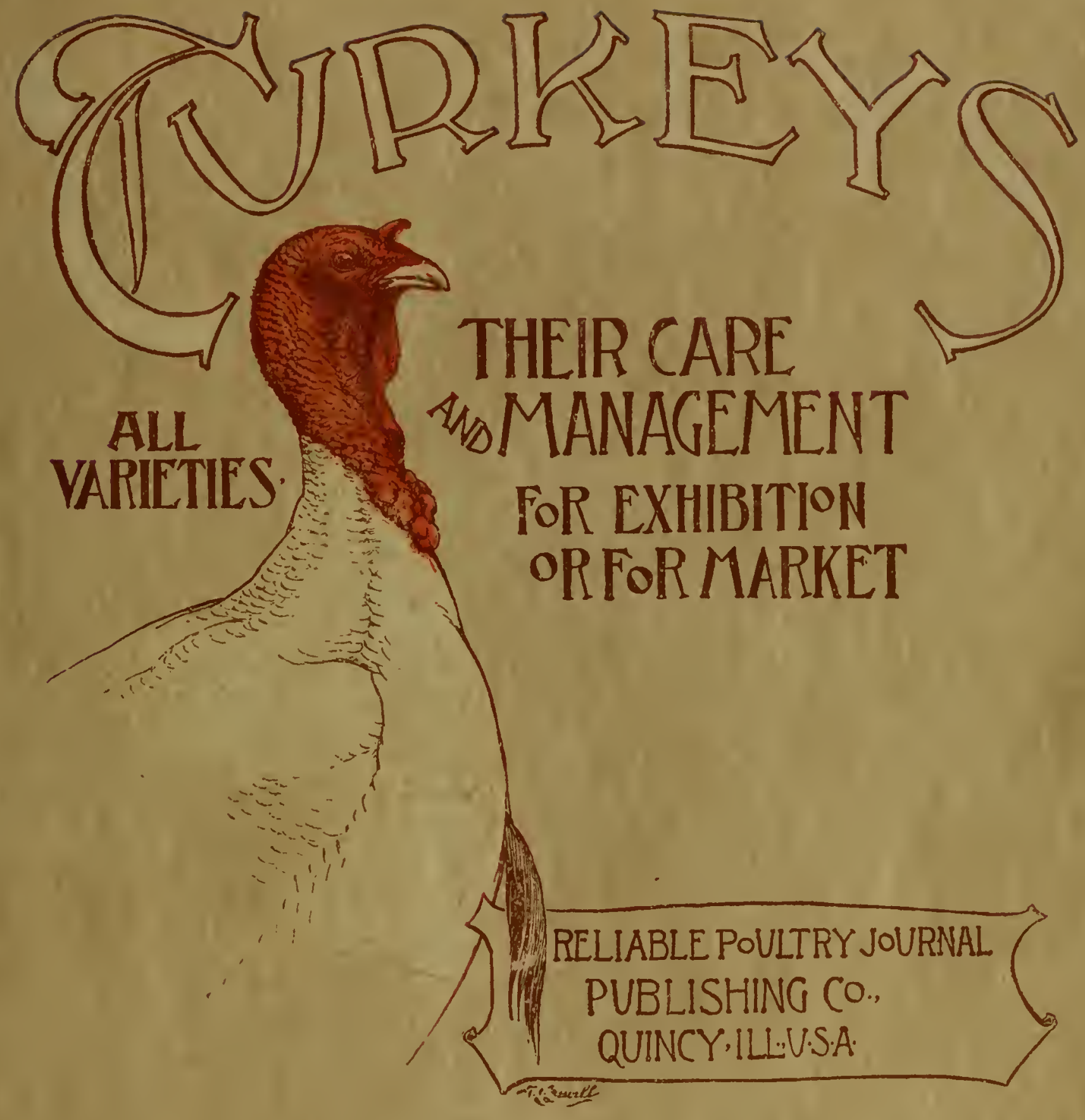





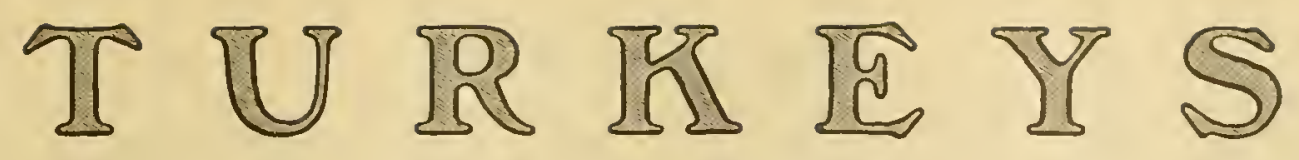

ALL VARIETIES

\section{Their Care and Management}

Mating, Rearing, Exhibiting and Judg̊ing Turkeys * Explanation of Score-Card Judging, with Complete Instructions

A Collection of the Experiences of Best Known Successful Turkey Breeders, Exhibitors and Judges 


\section{"A turkey boiled \\ Is a turkey' spoiled, A turkey roast \\ Is a nation's boast, \\ But for turkey braized \\ The Lord be praised."}

(C) 1.425134 ? 


\section{INTRODUCTORY}

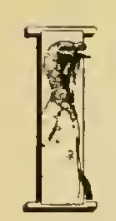

F THE American peuple have one fowl of which they are especially prond, it is the turkey.

One of our correspondents writes: "A Christmas without a Christmas tree, a Fourth of July withont firecrackers, would be on a par with a Thanksgiving without a turkey.

On November 21, 1620, the Mayflower with one hundred and two Pilgriuns cast anchor off Cape Cod. The first six months of their first year which was spent on the ocean edge of the wilderness, were fnll of hardships and dangers, many deaths occnrred and the small company was greatly reduced. Luclily the Indians proved to be friendly and tanght them how to plant maize, which they planted well, and in spite of the hardships of the first six months they considered the year comparatirely successful. William Bradford, their second Governor, on accuunt of this success proclaimed a seasou of 'thanlssgiving. It is supposed that this ilea was taken from the old English eustom of observing the harvest festival. The records show that the Governor sent four men out fowling and they brought in wild turkeys and partridges in abundance. From that day to the present time this holiday has been observed each autumn and the turkey has been the bird that graced the feast.

Although the turkey is classed with the domesticated fowls, it retains to a certain extent, the instinets of its wild ancestors and persons who are going to raise turkeys should bear this in mind.

Evel since their discorery in this conntry they seem to have been kept in a sol't of a domesticated state. The Cortez expedition into Mexico in 1518 or 1519 , found them in a state of domestication. The Pilgrims reported that some of the Indians had them partly domesticated, yet after all these years the bronze rariety especially, retains to a certain extent its wilı instincts and will do much better if allowed to roam. They may be kept enclosed dnring a certain period, say dnring the breeding season, but they will not do as well if kept continually confined.

The farm is the natural home for the turkey, and one that has a woodland on it is all the better, as it gives the tnrkeys : chance to indulge in some of their wild traits; it forms a natural breeding spot and furnishes food that is particularly palatable to their taste.

\section{BLEEDING TURKEYS}

Turkey breeders, as a class, have not given the stndy to turkey cnlture that breeders have to other branches of poultry culture, but they will almost without exception, tell you, "Do not in-breed." In-breeding or linebreeding should not be undertaken except by the breeders who liare the time and inclination to do a lot of hard work, for the love of it.

Tnrkeys in their wild state generally mated in pairs and during the breeding season it was a case of the "survival of the fittest." The survivor had his choice of the flock and proudly walked away with his mate. Cases have been recorded where a large, wild tom would fight and kill another tom and take uuto him the new mate, while his first mate was sitting. It is owing to this rule that we hare such a fine bird today. When man tries to confine and in-breed this great bird of the forest, nature steps in and says, "no."

Breeders hare had this pretty well drilled into their minds, many of them to their sorrow, conseqnently it is by continual outcrossing or the adding of new blood, that the vigor, health and size of the flock are preserved. Many prominent breeders line-breed to a certain extent; that is, they keep within one particular strain as much as possible, but they have to introduce outside blood every few years.

In mating domestic flocks one male can be given as many as eighteen or twenty females, but generally eight to twelve is the limit. Many breeders are glad to introduce wild bluod into their flock in order to get increased size and vigor. 'The bronze turkey's especially, have been bred so long and are so similar to the wild, that they breed very true to type and color, consequently do not need to be in-bred or line-bred as do some of our manufactured or irtificial breeds of poultry. They were already made when we first got them and man has been unable to improve upon natme; they are in fact the real descendants of the wild turkey.

Wild turkeys are hecoming very scarce and domestic turkeys are becoming tamer and less inclined to roam, becanse of the fact that wild tnrkey blood is harder to get and is not so generally introdnced as it was a few years ago. The wild spots in our conntry are becoming smaller every year; even the eattle of the western ranges have been deprived of their unlimited range which has been eut up into farms.

"Necessity is the mother of invention," still as the wild turliey blood becomes extiuct, the domesticated ones will hecome more and more contented to stay within the bomndaries of the home farm, and with the progress that is being made at the Agricultural Colleges in studying turkey diseases, we shall no doubt in a few years be able to raise turkeys in the little orchard back of the farm house. The old tom whose ancestors used to roam for miles and miles in search of conquest, will be content to settle down with his flock and the old hen will be indnced to sit in the hen bouse or box as contented as any old liddy.

\section{TIIE CARE OF TURKEYS}

As long as there is any wild instinct left in them we believe that the tnrkey industry will be benefitted by cultivating that trait as long as possible. It is natural for turkeys to roost outside. Let them do it. At one time we built a large turkey shed with good high roosts, etc. We fed them inside at night and slint them in, but the first time the door was open, up in the big oak tree they would fly, face the storm, draw their heads in like turtles and sleep all night, happy and contented no matter how cold and stormy it was.

They 1 ell ns that young poults should be kept confined until the dew is off the grass, and it is good advice. They will not stand dampness and no doubt many young poults were lost from this canse when in their wild state. Timbered lands where there is not much underbrush, make an ideal place for raising young poults. The turkey lien has a good chance to keep them dry and there is no wet grass to wet and chill them. Then, too, there is plenty and a rariety of nature's food for them and they are not as subject to bowel trouble as where they are liept confined and liable to be orer-fed. Lice will not bother them as much, for they have plenty of chance to dust themselves in the cool earth of the woodlands, neither will lice multiply as fast in the open as where the birds are kept confined.

It seems to be the general opinion that turkeys are hard to raise and perhaps they are, but if we will study 
nature and be benefitted by the lessons she teaches and accept the advice of others who hare learned their lesson $\pi \cdot e l l$, we ought to succeed. We used to think that artificial incubation was a failnre and it was, to a certain extcnt, until we studied the old hen and her methods and profited by what we observed, so today we ean hatch and raise chickens just as well, if not better, by artificial means as by nature"s methods.

lieep a hen and her brood in a coop for a weel or two and when released she seems to have accepted that as her permanent abode and will not go far away. Not so with the turkey. Confine her and then let her out with her brood and she will try to see how fal away she can get.

Young poults seem rery weak and it is well to keep them confined at night and until the grass is dry in the morning, as is advised in several of the following articles. The place to raise them in preference to all others is a woodland or some pasture where the grass is short and insects are plenty.

The breeding turkeys should not be too fat but should be put in good condition by being given free range all day and being fed their evening meal at home, which will induce them to come in at night. Some breeders at this time confine them in a large enclosure and keep them there until the hens have laid the next morning. These matters are all covered in the many articles throughout this book so we need not go into details. Turkey meat is the cheapest that can be raised on the farm and every farm should have its flock of turkeys.

In addition to being a cheap thing to raise, think of the many insects they destroy and turn into cash. Many a farmer's wife buys her fall and winter outfits, from bonnet to boots, witn the money she gets for the small flock of turkeys she gave a start and then let raise themselves.

\section{TIIE IBRONZE TURKEY}

The bronze variety is without doubt the most popular variety we have. They were recognized in our first Standard, known as the "Lockwood" Standard, which was published in 1871. The wording of the different Standards as they were revised from time to time, has been changed to keep the requirements abreast of the improvements made in breeding them. As has been said before, they are direct descendants from the wild birds and are frequently crossed with the wild in order to get more size and vigor. They are also the largest variety we have. IVe have handled or rather tried to handle one that weighed 62 pounds. He was the largest one we ever saw, but it is no uncommon thing to see specimens in our winter shows weighing 40 to 50 pounds.

In spite of the fact that exhibition specimens are very large and fine to look at, they sometimes get so large that they are useless as brecders and markets do not want such a large bird. The weights prescribed by the American Poultry Association in their Standard of Perfection, are believed to be the best for all-round purposes and it is well to stay pretty close to these weights for best results.

\section{STAYDARD VARIETIKS}

There are seren varieties of turkeys, that is seren varieties that are recognized by the American Poultry Association, as follows:-The Bronze, Narragansett, Buff, White Holland, Blaek, Slate and Eourbon Red.

The Bronzc variety is described at length in the article on "Juclging and Mating." Their principal defects are explained, also how much they should be cut in scoring.

The Blacks, Buffs, Slates and Narragansetts were admitted to the Stanciard in 1874 and are described in Mr. McClare's article, "Turkeys and 'Their Management." The White Holland variety was admitted to the Standard in 1878 and is also described in Mr. McClave's article.

'The Bourbon lieds, the new Standard variety just admitted to the Standard, originated, accordiug to the most reliable authority, in Bourbon County, Kentucky, and are brought up from what in the early days was called the wild Yellow Turkey. We have heard tourists of today, tell of seeing a yellow turkey in a wild state in Yellowstone Park. Standard weights for the Bourbons are as follows:-

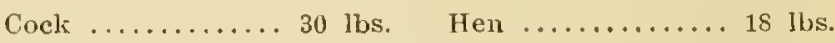
Cockerel ........22 lbs. Pullet.......... 14 lbs.

The neck and back color should be brownish red; the tail, white; the wingbows, deep, brownish red and the primaries and secondaries should be white. The breast and body should be deep, brownish red and the fluff, brownish red. The thighs are the same as the fluff, and the shanks and toes should be reddish pink.

\section{THE WIITE IIOLIANDS}

Next to the Bronze, in popularity, come the White Holland. For many years it was difficult to get the Whites up to Standard weight, but of late years breeders have been making some great improvements, and today we see specimens in our show-rooms that will. weigh 40 pounds. There is some complaint heard these days about getting the weight of this variety too high and it seems to be well founded. The Whites have won public favor by being a medium weight fowl and that is what the marketmen demand. We should dislike very much to see the Whites get too large and lose the prestige they have been gaining.

\section{THE NARRAGANSETTS}

Probably the Narragansett closely follows the White, as far as public favor is concerned. They have made some rapid strides toward the front, during the past few years, especially in parts of the New England States.

\section{CONCLLSION}

Our export trade has grown to such proportions that the home markets have felt it and the past two or three years have caused breeders to notice that the turkey crop was getting shorter each year.

Missouri, Fientucliy and Texas are probably the greatest turliey producing states. Eastern Canada also raises many turlieys, but we need more of them.

Rhode Island and the adjacent territory used to be one of the greatest turliey laising sections of this country. The dread disease known as blackhead, has practjcally wiped ont the industry in that section, in spite of the grcat efforts that liave been made to stop the disease. The State Agricultural College at Kingston, R. I., has heen making exhaustive experiments in combating blackhitur and other turkey diseases and their bulletins can be had upon application.

We trust as you read the following pages written by well-Jnown and successfuI breeders and study the cluarts d:awn by Mr. Framklane L. Sewell (the best thing of their kind ever drawn) that you will gain confidence and fecl capable of making a success of raising the ling of fovls. the birel that is so near to nature, that is liked by ereybody and whose lestiny is a Thanksgiring feast. 


\section{HOW THE TURKEY GOT ITS NAME}

Our Domestic Varieties of Turkeys are Descended from the Wild Turkey of North America-Three Varieties of Wild TurkeysGrowth of the Word Turkey-The Introduction of Turkey into Europe-First Sent to the Old World by Cortez

\section{1). E. HALE}

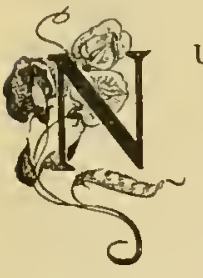

UMLEIOUS writers in the past hare endearored to trace the origin of onr national bird aud to learn the derivation of its name. They have agreed on many points and differed on miany.

For the historic information contained in the following article, we are pleased to give eredit to the gentlemen who, have charge of the Reference Department in the Luffalo, X. Y., Public Library, who very courteously assisted the writer in his search for authentic information in regard to turkeys.

There is little doubt that our domestic varieties of turkeys are all descended from the wild turliey of North America. Llow and when they were developed forms an interesting study.

Lewis Wright, the great English writer and authority, in his book "Ihe New llook of Poultry," says in speaking of their originating in America: "I'his is no question now; and the obstinate incrednlity of some naturalists respecting the fact is one of the most curious phenomena in the history of science."

Americans generally believe our grand bronze turkey is the lineal descendant of the northern wild turkey. Why

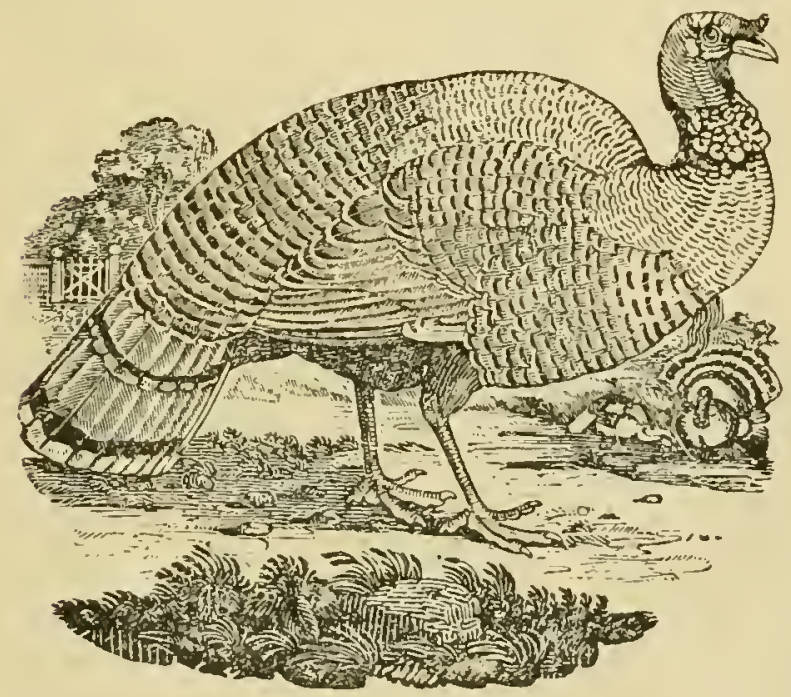
A reproduction of the male wild turkey as shown in "Burnham's
New Honltry Book." published in 1877 . "rhis picture certainly" resembles the peacck to a great extent, and it is nut surprising

northern? In orcler to make it clear let us explain that there are, or were, three varieties of wild turkey's. Those found in Ilonduras and Central Imerica were known as "M. Ocellata," and were distinguisleel by the absence of the breast-tuft. They also had a different carnnculation and a mued brighter plunage. Those found in the southern states and Mexico were linown to the naturalists as "M. Mexicana," while thuse of the northern states and
Canada were known as "Mleleagris Americana." These latter were darker and more bronze in color.

Some naturalists think that the brighter plumage of the southern birds was caused by the warmer climate where a larger assoltment of food was to be had, orving to climatic conditions.

The northern wild turkey being more bronze in color and also more robust, owing to climatic and food condi-

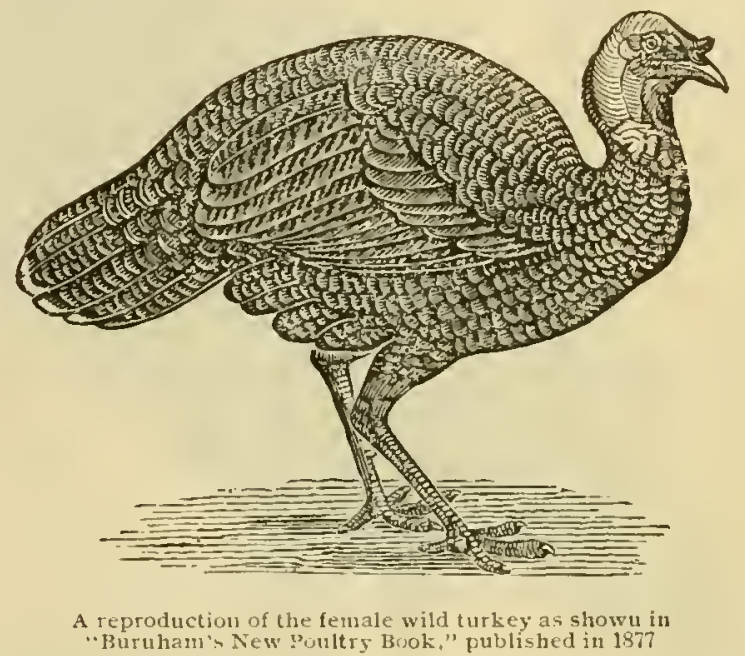

tions, it is quite reasonable to presume that it is from this variety that we have ou elegant bronze turkey of todlay.

It is hard to say when turkeys were first domesticated. The fir'st settlers who landed on our shores found that some of the Indians had them in a sort of domesticated condition. We will go back farther than that, although these same domesticated turlieys may have been the progenitors of our bronze turkey.

\section{THEU: WTLOHT"THS IXTO ELROPE}

Let $\mathrm{ns}$ see whence the name came and in loing so we will be able to tell of their introduction into Europe.

lir. Wright in his book mentioned abore, says: "As no one ever supposed that these birds came from Turkey, or anywhere except Forth America, not one single old writer can be quoted tor any such mistake. 'The origin of the name is a very curious question. Some have suggested that it cane from a supposed resemblance of the reel carunculations to the old 'lurkish costume of a red fez coming down to the ears, with a clark flowing robe beneath. Inother guess is that the word is corrupted from truquoise, supposed to be applied to that bluish carmenlation abont the heal. Others point out that the name of 'A 'l'urk' is often applied in popular' langnage to any one remarkible for domineering and pompous disposition or appearunce and thus it became attached to the turley cock, and gralually modifierl." 
We personally are inclined to agree with Mr. E. Richardson who in the book entitled, "Turkeys and How to Grow "Them" salys that the name was derived from the Ilebrew worl "Tukki," meaning peacock.

Prescott in his "Conquest of Mexico," explains how Cortez was sent on his royage of discovery and conquest, and that he was to send to his emperor one-fifth of all the spoils taken, etc. We quote Mr. Richardson as follows:

"The introduction of the bird into Enrope naturally followed, and not lung after, for in July, 1519, Cortez dis-

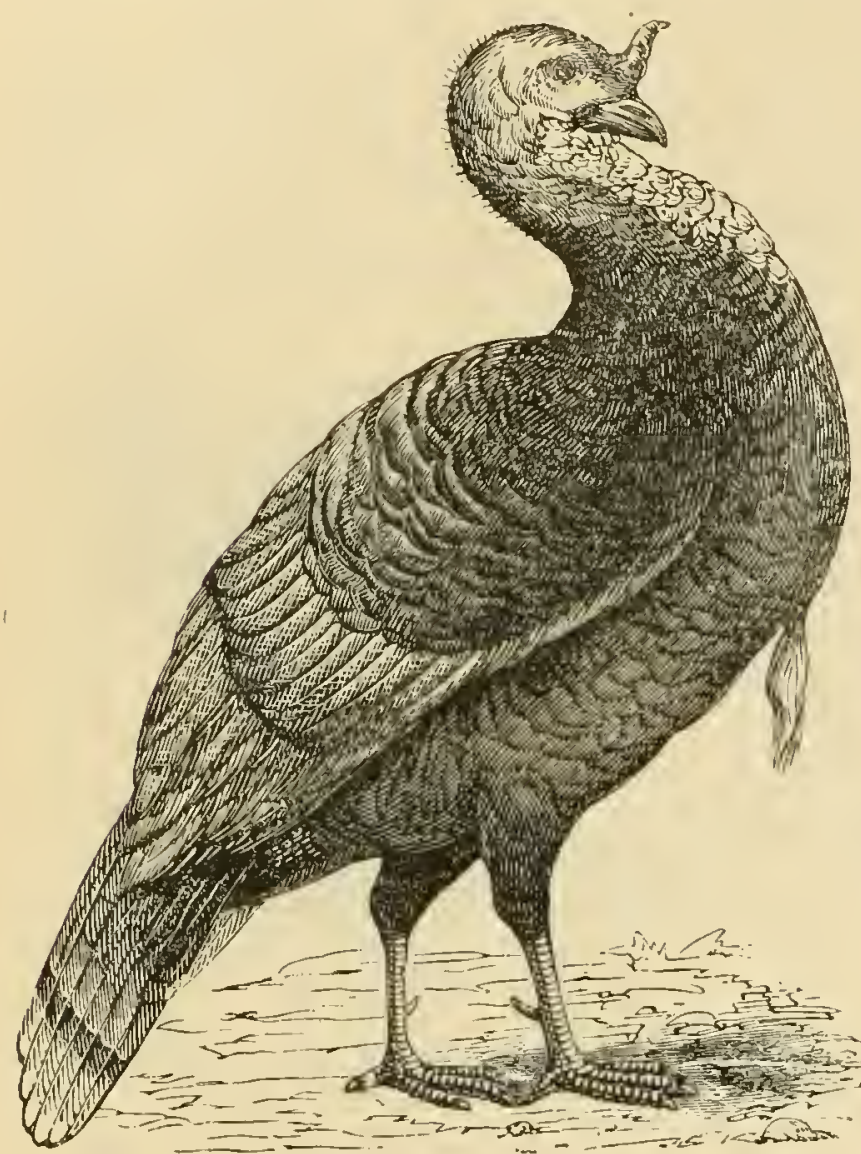

Mammoth Bronze Turkey, reproduced from "Burnham's New Poultry Book," published in 1877 .This shows the type of turkey that has been crossed with the wild turkey, which cross has been

patched 'his first letter' to his emperor, Charles the Fifth, with a collection of fabries, minerals and other products of the new world, and it is not to be supposed that the turkey was omitted, especially as it was so easily obtaincd. History tells us that the turkey was first brought to Encland in 1524, tive years aftel Cortez sent specimens to Spain.

(Note:-This introduction into England is 17 years earlier than is claimed by Mr. MeGrew in "Bailey's Cyelopedia of Agricultnre," which gives 1541 as the date.-D. E. H.)

At first it was only in the hands of the rich, as natnrally would be the ease, but in course of time became accessible to the poor as well. So mueh then as to the origiz of the bird itself, in which is shown how it is a native of Mexico, and was introduced into Europe by the expedition of Cortez to the new world, and called by his followers the 'Imeriean' or 'Nlexican' peacock from its habit of strutting.

"Strange, then. how the bird eame to be called turkey, a word in no way similar to the Anglo-saxon pawa, the German foul, the French paon or the Latiu pavo, all names similar to one another and derived from the Latin, the bird (peacoels) having been bronght from the east by the lomans. Ihe mystery then is how, in view of all these facts, the name "turkey" came to be applied to this bird. It is obvious that we must look to some other language for a solution to the problem. Going to the far oft hume of the pencock, we find in the Tamil language of India, a word 'toka'-peacock, the primitive meaning of whieh refers to a train or trailing skirt. This worl adopted into the Hebrew language becomes 'tukki' and by a slight change of the genius of the English language becomes what we are looking for, 'turkey.'

"But it is asked, "How came it through the Hebrew?" Let it be said. then, that at the time of the expedition of Cortez to Mexico the despised and perseented Jews were very numerous in Spain and engaged, as they usually are, by their natuml aciaptability for gaiu, in merchandising. Their acntemess led them to deal in foreign bilds, curiosities and rarities, by which they reaped large profits, as these things wcre only purchased by the rich. Naturally, then, they saw iu this new importation an opportunity for gan, which they scized, and as they used their own language as much as possible, it was not long before the Hebrew name for peacock became well known. Doubtless they designated it as the 'American' peacock, for it was well known whence it came.

"'Thus it would be constantly heard in the marliet plices, while the more scientific name of 'pavo' wonld only be heard among the educated few, and so by force of numbers the name was used and anglicized into turkey.

"Furthermore, the name was formerly spelled 'turky,' as when Corbet, Bishop of Oxford. writes to louckingham:

"Like very poore or counterfeit poore man, who, to preserve their turky or their hen, do offer up themselves.'

In tracing the word to the Hebrew, the rules governing ef ymologies have heen eomplier with, since nere we have preserved the radicals ' $T$ and $k$, whieh fact only tends to prove the origin of the word, according to the views berein set forth."

After investigating the authorities available, we are inclined to believe that $\mathrm{Mr}$. Richardson is right in regard to the origin of the word and also about the introduction of the turkey into Europe.

It is cuuite reasonable to presume that the Mexican or sonthern turkey was the first introduced thronghont Europe. Later, when the pilgrims settled here and found that the Indians were domesticating them and that they were numerous in the woods, they were no doubt used as a bild of feast, owing to their size and numbers.

"Holy Days and Holiday's" by Deems, says in regard to Thanksgiving:

"When after the ingathering of the first harvest in a new world, Gor. Bradford sent four men ont to shoot wild fowl that the infant colony "might after a more special manner rejoice together, he little dreamed to what that pious act would grow."

It was not until the Revolutionary War that the feast became national and after 1784 it was only occasionally observed, except in New England.

Henry Austin in "Holy Days and Holidays" writes, in speaking of the four huiters mentioned: "They killed nany wilt turleys which the women in dressing probably stuffed with beechnuts, and they brought home woodpigeons and partrirges in abundance."

As the climatic conditions of the north gave the wild turkeys of that section their bronzy color and hardy eonstitution and as it is a fact that the Indians were domesticating these turkeys when the country was discorered and that our ancestors were progressive, we believe it is safe to conclude that our bronze turkey of today is descended from the "Mleagris Americana." 


\title{
TURKEYS AND THEIR MANAGEMENT
}

\author{
Origin-Description of All Standard Varieties-Breeding-Feeding-When to Market-Turkeys Pay the Greatest Profit
}

CHAS. NGCLAYE, 1909. AMERICA'S PREMIER TURIEY JUDGE

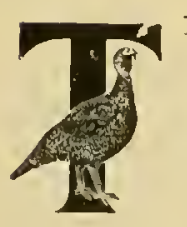

IIE origin of the domestic turkey is in a sense almost unknown. Turkeys have been bred as a domestic fowl for hundreds of years in the United States and Europe. Turkeys as a fowl or bird may be divider into four classes, as follows: The Wild American turkey of the United States and Canada: the Mexican turliey of Mexico, Central America, and the northern portion of South America; the Occllata variety of Honduras, and the last. but not least, our Standard varieties of domestic turkeys.

\section{STANDARD VAIIETIEN}

The American Standard of Perfection recognizes seren pure or Standard rarieties as follows:-The Bronze, Black, White IJolland, Narragansett, Buff, Bourbon Red and Slate. Fronze are the largest and most numerous of all our domestic varieties and are purely American, having been a cross of the American Wild and the common domestic turkey brought from Europe.

\section{THE JRONYE TURKE)}

The cross has produced the largest and hardiest turkey known. The well bred Bronze of today rivals the famous American Wild Turkey in brilliant color of plumage and beauty. The Standard weights of Bronze are as follows:-adult gobblers 36 pounds, adult hens 20 pounds, young gobblers 25 pounds, pullets 16 pounds; howerer, these weiglits arc far exceeded by some specimens found in our large poultry shows.

At the last New York show held in Madison Square Garden last December the writer found several adult males weighing over 40 pounds each, and hens as high as 30 poumds, making a single pair, weighing above $\tau_{0}$ pounds. These are extra weights and are valuable for show purposes, but as a rule do not make the best breeders. For general purposes and in the breeding flock I prefer a medium sized Bronze. A young gobbler weighing in breeding condition 25 pounds and pul]ets 15 to 17 pounds, or hens 17 to 20 pounds, make the best breeders.

It is desirable always to mate not akin if possible, which insures a much stronger chick or poult. The gobbler whether old or young should be large in bone and frame, deep in body, with deep, round, full brcast, head of good size, and eye alert, with bold expression.

The leg and shans should be, large and straight, with mutlines of all sections in perfect harmony. The hen should in every way conform in outlines to that of the male, excent in size.

In color the entire plumage of the male sliould be a rich, brilliant, golden bronze, for neck, back, breast and surface of wings. Wing flights when spread are black with white barring across each feather, the more regular the better.

The tail is black, evenly marked, transiersely, with parallel lines of brown, and each feather ending with wide edging of white. Red or rusty tips are very objectionable.

The color of the hen is similar to the male, except an edging of white or gray on each feather of the breast, body, wings and back.

As layers the Bronze surpasses all other rarieties, and if not allowed to sit, will lay from three $t o$ four clutches of eggs of from 13 to 18 in a cluteh.

\section{THE IBLACK TLRKEY}

One of the most promising varieties, the Blacks, are being bred in large numbers in some sections at the

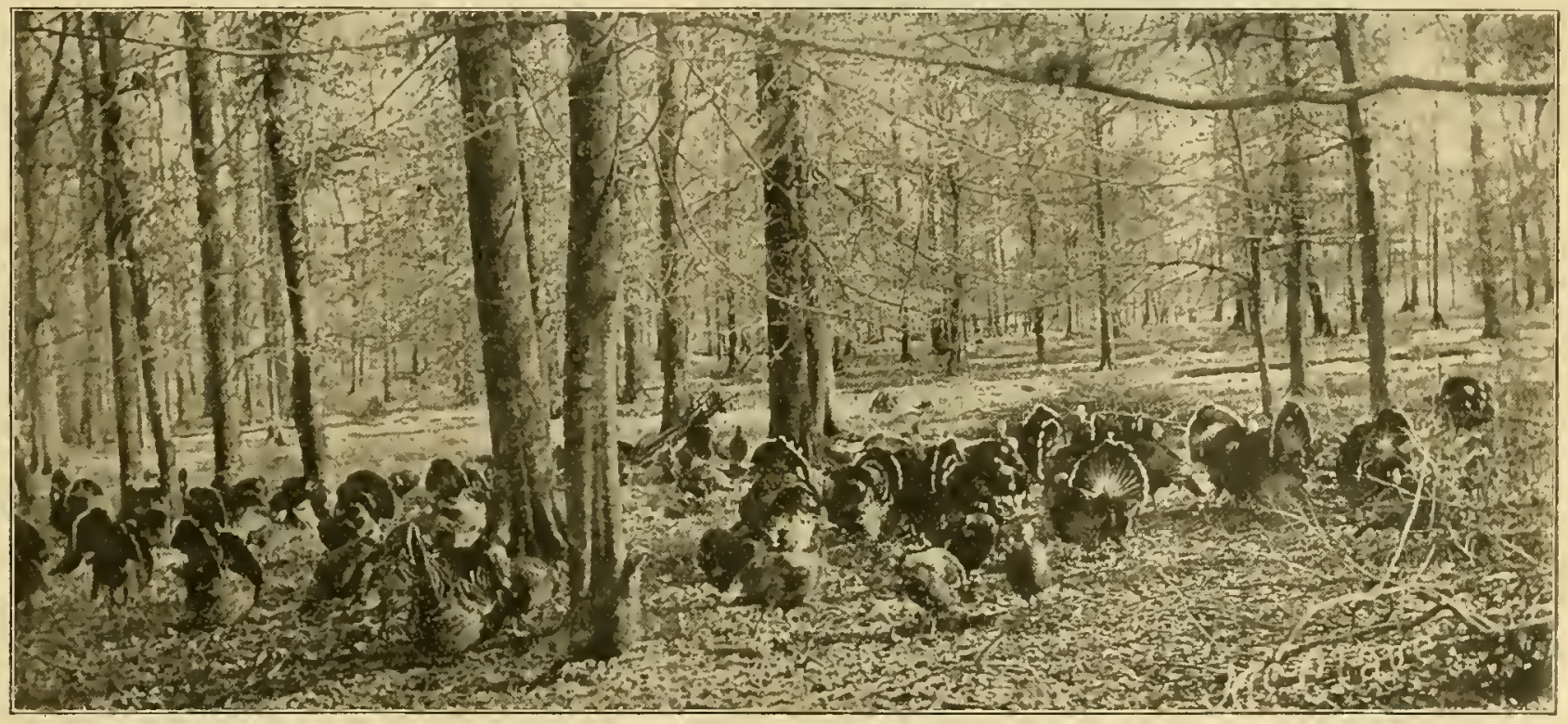

Bronze Turkeys on the Farm of Mr. Chas, McClave. 
present time. The modern Black turkey is nearly equa] to the Bronze in size. The old style Blacks were not only inferior in size, but poor in quality; however, by careful breeding and handling and with an infusion of new blood, they have been greatly improved in size and

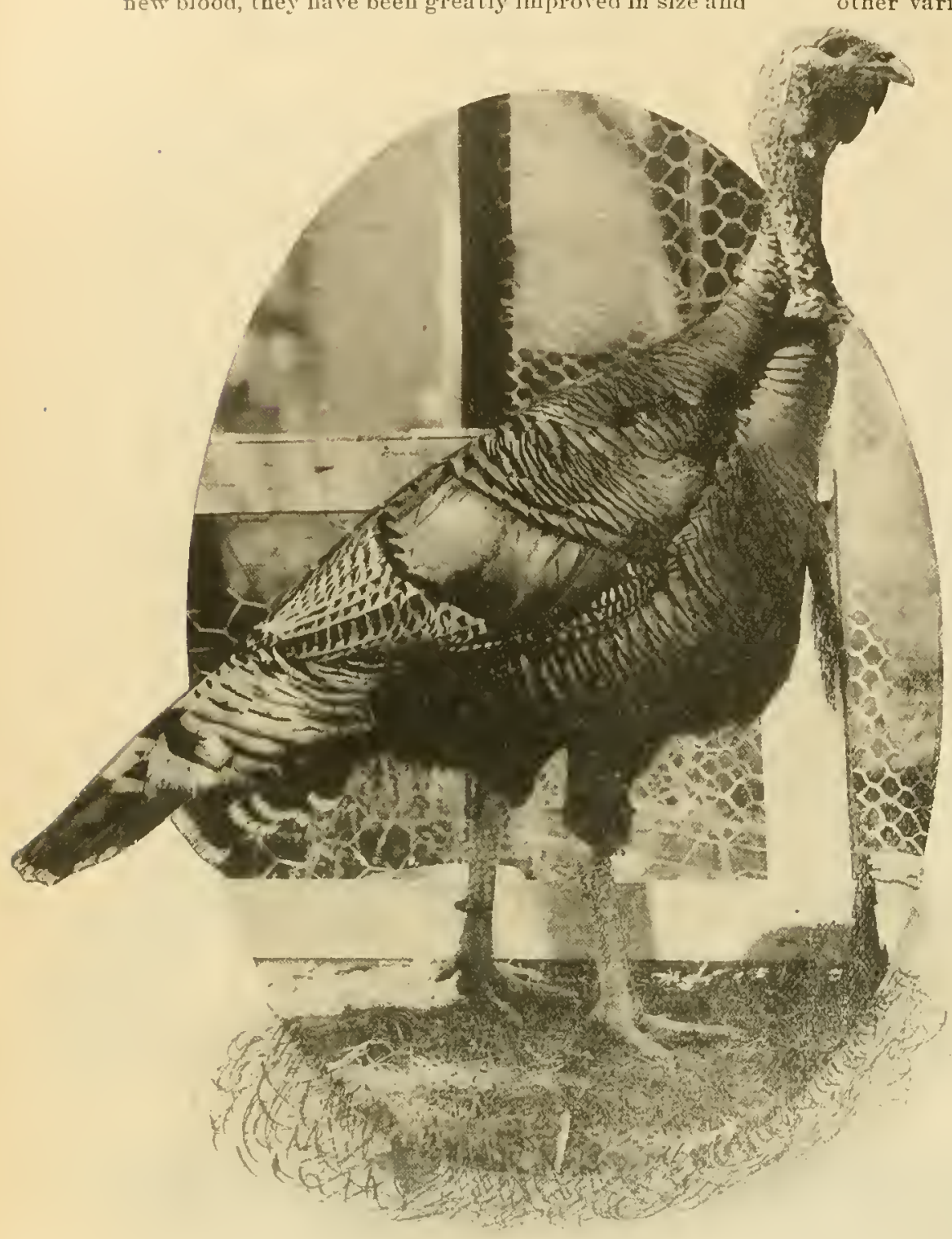

A Fine Specimen of the Mammoth IBronge Turkey ippear at maturity. Good strains of Blacks are strictly hardy, their eggs hatch well, and they are fully as good laycrs as the Bronze or White. They are very clocile in their habits and are not inclined to ramble as much as other varieties. The young grow lapirly from the start, and at selling time always command the top of the marliet.

The head and beak should be long and broad and of good sluape; eyes bright hazel; neck of medium length and well curved; back broad, of good length and highest in the center and curved the shape of an egg. The breast should be broad, deep and full; body of good length and round in outline; wings of good length and snugly folded against the sides; tail of medium length and when folded comparatively small. Thighs, shanks and toes should be of good leugth with strong bone and perfectly straight.

The Black Turkeys are also an American production; however, the Norfolk or Black Turkey has been bred in England for more than two centuries. Thirty years ago the Blacks were, as a class, small in size but by the judicious infusion of Rronze blood they hare greatly improved in size and nearly rival the Bronze in this respect.

When the good qualities of the Black Turliey become better known we predict that they will rival their Bronze and White cousins in popula rity.

\section{WHITE IIOLLAND TURKEYS}

The White Holland is also a native of America. They are a sport of the Bronze or dark varieties.and were also rated as a small turkey until within the past twenty years.

Iiy careful breeding and the introduction of new blood from larger varieties, they have been greatly improved in size. They are the most domestic in their habits of any variety and not inclined to roam; are the best of layers; a fine lable fowl, and in the past few years a great demand has developed for their feath. ers. Narket turkey buyers and dressers ali over the country are urging farmers and growers to breed White Holland turkeys on this account.

\section{TIE NALRATANEETT TURKEL}

general make up. To attain their present weights and general characteristics there is no question whaterer but more or less Bronze blood has been judiciously used.

From a market standpoint there is no question but the Blacks will dress jellower and even plumper than any other Standard rariety. The Standard weights of Black turkeys are: Cocks, twenty-seren pounds; hens, eighteen pounds; cockerels, eighteen pounds and pullets, twelve pounds. At the present time these weights are entirely too low except ou hens. We liave no trouble at Christmas time in having pullets from fourteen to fifteen pounds, coclierels twenty to twenty-four pouuds and cock birds thirty or over. The Standard requires males and females to be lustrous black throughout, but it is a difficult matter to secure young birds with solid colored plumage, as more or less feather's in wings will invariably be tipped with white. This will usually dis-
The Narlagansett turkeys are a large variety nearly rivaling the Bronze in size, and are a native of New England, having derired their name from the Indian tribe, also Narragansett Bay on the east coast of Rhode Island.

They are bred largely throughout New England and the Itlantic coast and are becoming more popular in the west. As a market variety they rauk well with the other large kinds.

In color they are different than any other kind, the ground color being black, each feather ending with steel sray, edged with black, giving the entire plumage a nrayish effect. See illust'ation page 9. 'l'he male and female are the same in color except the female is a shade the lighter. 
THE BUTES

Bnff turkeys are one of the older varieties; however, they have never been popular and in some localities are practically unknown; are of medium size and rarely ever attain Standard weights. Very few specimens have ever been produced that are really buff in color, as they usually are of a chestnut or reddish sliade of color with white flights. They are fairly good layers and good specimens inature early.

\section{THE SLATE VARILT}

Slate turkeys are a medium size turkey and sports from other Standard varieties, are slate or blue in color and many times will produce black and white specimens from the same flock. They are only bred in small numbers, therefore have never been popular. Some very grood ones were shown at the New York show last December, especially the first old cock bird. They are fairly good layers, and shonld receive more attention from turkey growers.

\section{THE BREEDLNG STOCK}

In selecting the breeding stock, no matter. what variety, they should be well matured, strong, vigorous, and lealthy. Yearling and two year old hems will lay larger eggs and produce stronger poults than eggs laid by pullets.

Always use a gobbler not akin to the hens, which insures strong poults. Avoid large or overgrown specimens as breeders. 'It is not necessary to have more than one male to six to ten hens under ordinary conditions. If more than one male is used with the flock, keep one yarded, changing them from two to fire times a week.

During the laying season if two or more males run with the flock they are constantly fighting and destroying each other's work. Past experience has taught that the breeding stock thrive better with free range of the farm; however, if provided with il large yard or orchard, they can be kept confined during laying time.

In most localities this is almost a necessity on aecount of crows robbing the turkey nest.

\section{WHAT TO FELI}

To insure good health, the breeding stock must be provided with a rariety of grain, grit and charcoal. As a conditioner and health preserver, charcoal has no equal for the turkey family. When turkeys hare free access to charcoal very few will become sick or ailing.

The writer has found oats to be the best all arouud grain for turkeys, especially during breeding time. A small amount of corn and wheat call also be fed to good advantage. Orer-fat specimens are as a rule very poor breeders. Turkeys require a considerable amount of water and should always have a liberal supply.

Where the breeders have the range of the farm they require very little grain food after they commence to lay. Many farmers hitch the first laying of turkey eggs under chicken hens and the turkeys sit and hatch the second clutcl.

While some make a success by this method, many more make a failure, as roung poults do not thrive with chicken hens, for two principal reasons, namely, proper food, and lice. In their watural state the roung poults live almost entirely on insect food, which is not ind cannot be provided where brooded with the chicken hen, therefore we are feebly trying to make them thrive on food entirely foreign to nature.

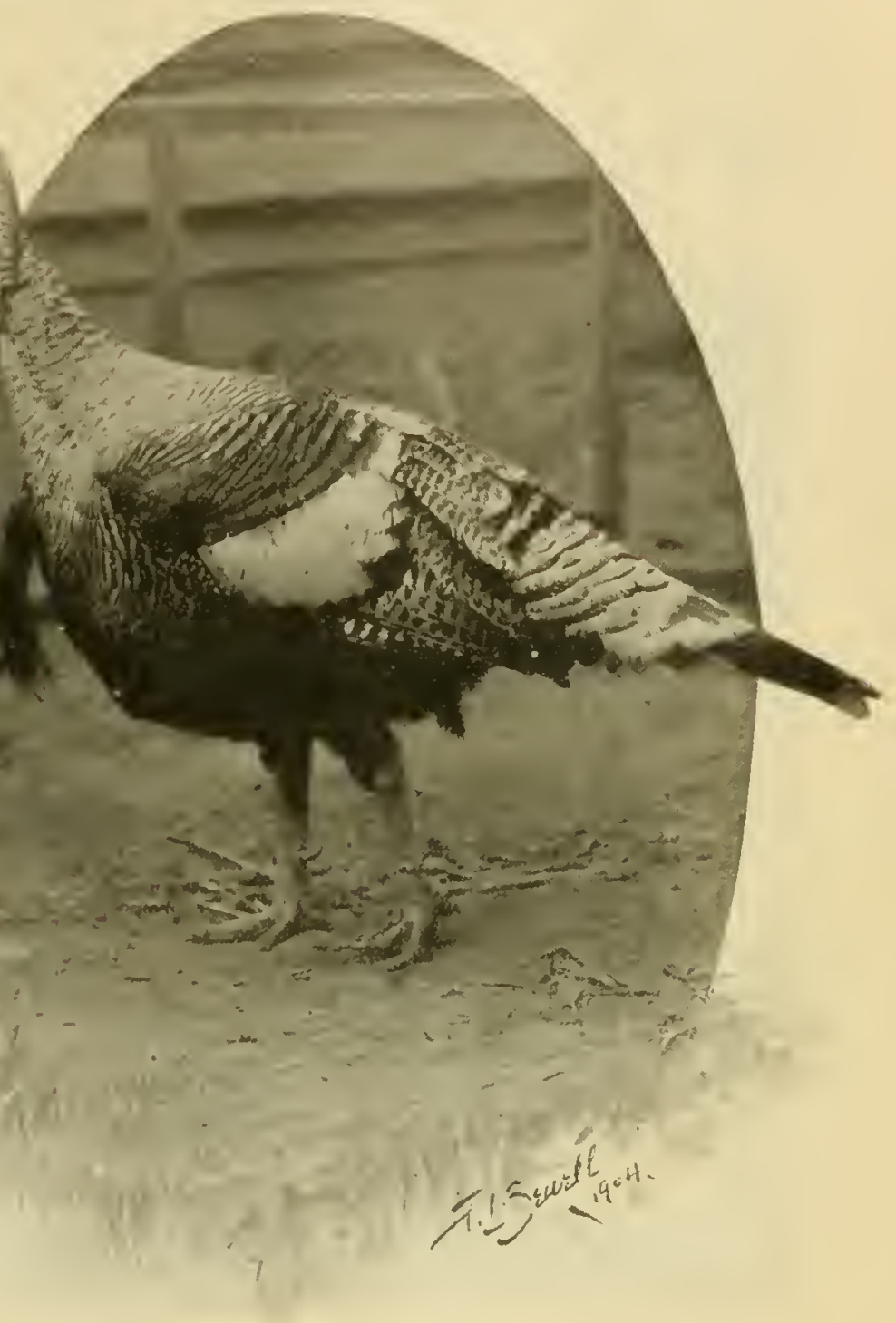

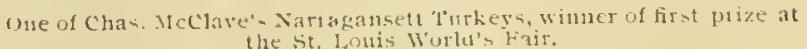

Every chicken hen will trausmit enough lice to the young poults to injure them to a greater or less extent. 'The writcr strongly recommends the hatching of all turkey eggs by the turkey hen, which is the only uatural mother. If you must hateh with ehicken liens, use plenty of insect powder before the eggs hatch.

After the poults hatch, isolate-them from the flock of chickens to a dry sunny place and after thirty hours old give a ration of hard boilerl eggs and bread crumbs. When a few days old add cracked com and wheat, cottage cheese, and in fact a little of ererything they will eat.

Inimal matter should be supplied for young poults, whicls can be provider in the form of ground meat scraps, beef liver cooked and chopped fine. This must be fed at least every other clay and in a small quantity at a time. lieep a liberal sinply of fresh water and granulated charcoal before them at all times. Never allow their coops or riuns to become wet or filthy. If possible move the lun crery two days to a fresh ground. 
as in a natural state they rarely evel remain in the same place more than one night.

Ifter they are fomx weeks old, turn them loose to lange over the farm, and still supply them with wheat and corn until grasshoppers become plentiful. I beliere a flock of 25 to 50 turlieys ranging over a farm are a lenefit to any farmer because of the thousands of insects and worms which they devour daily. All these insects and worms destroy a large amount of grain and grass every rear, on every farm. On our own farm turkeys have been kept for near 30 years and in numbers from seren to four hundred and fifty head, and during

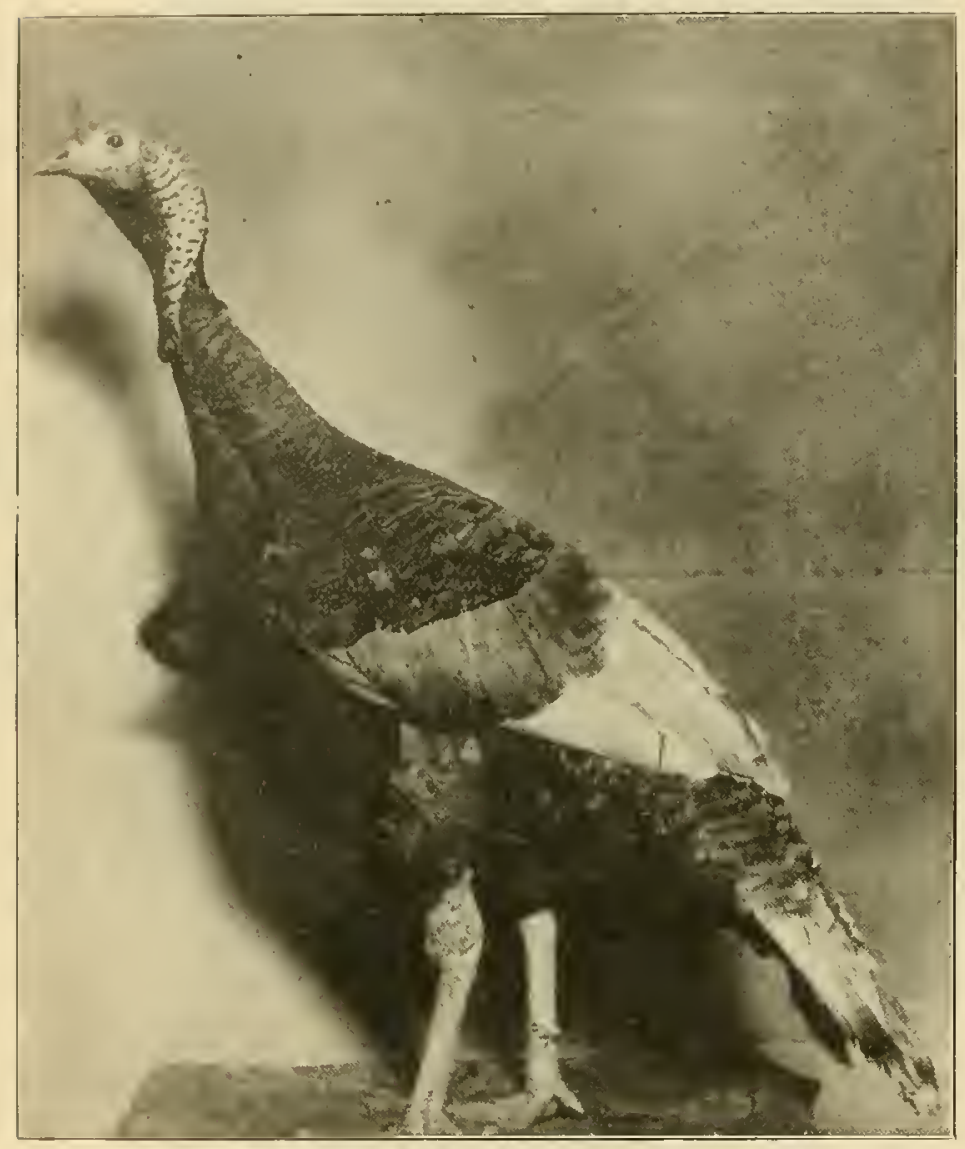

Buff Turkey Gock

A specimen of this rare variety of the turkey family which won first prize at many State Fairs in the hands of its owner, Mr. A. J. Ziemer.

lhat time they have larely evel iestroyed wheat, oats or corn when in the shock. 'T'his cannot be sail of other joultry, as chiekens, geese and ducks will destroy growjug and shoeked grain should they have access to the sา111?.

\section{WHEN TU MIRKET}

Past experience has taught that to keep your turlieys liealliy, lieep them husy and on the move. The busy turliey is the healthy turliey. Always encourage them tor come near the buildings to roost, by a liberal supply of grain at right. During October inerease their grain rations and by November give them all they will eat. Oats and corn equal parts are the best for this 1murpose. Many farmers get excited and rush their turlieys off for the Thanksgiving market regardless of flesli, and it is safe to say that fully 90 per cent of the turkeys marketed for Thanksgiving are thin in flesh and not fit to go, while on the other hand if fed until Christ- mas they command the same price per pound and sain in weight from 20 to 25 per cent.

I have heard farmers with a flock of $30 \mathrm{or}^{\circ} 40$ head wt turkeys say they eould not afford to feed them longer than Torember $15 \mathrm{th} o \mathrm{l}^{\circ}$ 20th. when they were offered 15 cents per pouncl, live weight, while at the same time they were feeding a bunch of hogs at fom cents per pound ant really maling themselves believe the hogs were maling them money. After feeding both for many years I frmly believe that a pound of turkey meat can he made cluring Oetober and Norember just as cheap as a pound of pork, and there is a noticeable difference between four cents a pound for one and fifteen "ents per pumal for the other. In pronf of this statement. I have not owned or ferl a hrig on my home farm for three years, but have feal as many as tho turkeys at one time.

Une day recently Clereland market quoted logs at $\$ 6.50$ per hmulyed and turkeys at $\$ 20$ per hundred. Tlese comparisons are made simply to show the difference in value of the two farm eonnouties; however they aro mot made to discournge the grower of hogs on the farm. 1 ani safe in saying that not more than one farmer in teu the siate over. grows any turlieys, therefore it can easily be seen that fully fire times as many turkeys could be grown and maxleted as are prorlueed at the present time.

Fully 90 per cent of the farmers in ohio who du raise turkeys, sell too elose and retain too few for hreeders for the coming year. Many will only reserve a gobbler and two small hens. when fom or eight would prove large money for them.

\section{TIRKEYS THE BEST PROFIT I'AYEIS}

As an illustration of what can be and has been done with a few turkeys, will state, that one of my neighbors a few years ago purchased a trio of young Bronze Turkeys for $\$ 9.00$, and with the use of some chicken liens to hateh the first eggs, he raised 63 liead of young turlieys. and in Norember he sold the entire lut to at buyer at market rates for an even $\$ 100$, and the purchaser fook them at the farm with no time or expense lost for the grower in delivering. 'These same turlieys were later retailed ont for breeders for more than double the $\$ 100.00$.

At this date (March 4th) good breeding turekeys can hardy be found at any price. On February $25 \mathrm{l}_{2}$ to test this matter I sent letters to thirteen Bronze turjey breeders and all wre adrertisers at this writing in leading agricultural journals. When replies were receired, only six of the thirteen had a turkey left to sell, the others were sold out. The six that had a few to sell, which were mostly ]ate hatched, were quoted from $\$ 5.00$ to $\$ 20.00$ each, with the positive injunction to order at once, for they conld not guarantee to holl even fire days. This shows conclusively that the demand far exceeds the supply in Bronze 'Turkeys, or in fact any other variety for breeders.

I believe no branch of the ponltry business on the farm offers so much opportunity, considering the investment, to make a few dollars as the breeding of turkeys. No housing in winter is necessary as they prefer to roost in the trees about the place, or on the ridge of some building on the farm. 


\title{
STANDARD-BRED BRONZE TURKEYS
}

\author{
An Illustrated, Detailed Deseription of What The Standard of Perfection Requires in Bronzz Turkeys, Male and \\ Female-Instructions on Judging by Score Card
}

\section{E. HALE, WITH SPECIA, CHARTS BY MR FRANKLANE L. SEWELL}

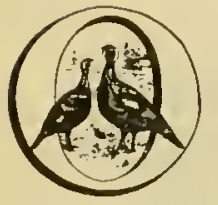

UR national experimental stations have done some gool work in investigating several of the very troublesome and fatal turkey diseases and many exeellent articles are written each season by our most prominent breeders, on breeding, care and management of turkeys, so that turkey culture today is not such a hazadous mudertaking as it was a few years ago. The turkey is a]so becoming more popular as an exlibition fowl and many fine exhibits are seen at our annual poultry shows throughout the country. While there are presented in this book many excellent articles relating to turkeys and turkcy culture, we realize that many of our readers will wish to exhibit some of their choice specimens and for that reason this artiele has been prepared. We shall try to show how a turkey is scored and why the cuts are made. By the word "cut" we mean the amount deducted from the number of points allotted each pexfect section.

For the benefit of those who are just starting to raise turkeys and who perhaps hare never exhibited poultry of any kint, we will say that in scoring a turkey we work on the basis that a perfect specimen is valued at 100 points, a certain number being allowed to each section, so many for shape and so many for color. The judge examines eael section, first for shape, thel for eolor, and dednets whatever amonut he thinks is lacking from perfeetion.

I'ietures usually speak plainer than words, henee in order to give a clearer idea of the correct markings of each seetion, we have had the cliarts which appear in connection with this article, prepared by Artist Sewell. These ehalts showing the feathers as they appear in the different seetions of the fowl, we believe will give the amateur a elear understanding of the plumage and a feeling of confidenee in selecting bis show speeimens and breeders that he could obtain in no other way unless he visited shows and studied the living birds under the directions of a competent judge or breeder, or visited a suceessful breeder's yards, eitlier course being frequently ont of the question. We present a chart of a male and female Iironze tnrkey which will be referred to as Figs. 1 and 3 in our deseription.

There is always something to be learned so we trust that every reader, both the experienced turkey exhibitor and the amateur, will derive some benefit from it.

Of course, we must take as our gnide, the Standard of Perfection. We shall try to give in a clear, concise manner our interpretation of its meaning as applied to Rironze turkeys.

\section{SYMMETRY}

Symmetry is the first section that appears under the Scile of l'oints. There is probably no section that has been so much abused, or so little understood as this one. It is no wonder that it was redueed to four points when it had heretofore been valued at eight points. Judges pay too little attention to this important seetion and do not study it enough to get a clear understanding of its true meaning. The Standard lefines it as, "Perfection of pro- portion; the harmony of all the parts or sections of a fowl, viewed as a whole, with regard to the standard type of the breed it represents."

The latter part of that definition is what should be kept in mind at all times; i.e., "viewed as a whole, with regard to the standard type of the breed it represents." It has been described as "Typical Carriagre" which caused more or less disputing. The following illustration may help our readers to an understanding of the term. Notice a company of picked soldiers coming down the street, they mareh in perfect time, with shoulders baek, chests out and heads erect, the symmetry of each one and of the whole borly is nnquestioned. But notice the same men in quarters. They are the same men with the same clothes but they are relaxed, they lounge about with shoulders droped-symetry is laeking.

In order to present your turkeys to best aclvantage to both the judge and the public, each one should be cooped separately, and the coop should be large enough so tnat it can turn around and stand naturally without having the tail broken and twisted and the head forced into an unnatural, uneomfortable position. Insist that your turkeys be cooped singly.

\section{TIIE MULE TLRKEY}

Now let us study the symmetry of the male for a moment. He should be large in frame and deep in body. with a broad, full, well rounded breast, which raries in prominence aecolding to the variety and which gives the fowl a stately, majestic appearance. The head should be of good size, long, bruad and carunculated, while the eye should have an alert, bold expression; the legs and shanks shonld be large, strong and straight and the different sections shonld larmonize one with the other.

We must remember that we are scoring these turlieys according to the latest Standard of Perfeetion whieh groes into effeet July first, 1910.

Symmetry is now worth but four points; it was formerly worth eight. In lonking at Fig. 1 we see a perfect specinen or one as near perfect as can be depieted by the greatest poultry artist. We find eaeh part harmonizing with the other and each part or section perfeet in itself. Were we judging a living speeimen that showed the perfection of every part or section and all parts harmonizing as they do in Fig. 1, we could not eut anything for symmetry. But, were the tail too long and earried too high, we should cut one-half point, if the breast were immature or flat and the neck apparently too long, giving the fowl a lanky, ungainly appearance, we should eut a half point, if the bird were too narrow across the breast and back when riewed from in front and above, we shonld eut one-half point. An ontline drawing does not gise the true idea of symmetry because breadth and thickness are to be considered as much as the profile or outline. In $155 s$ the Ameriean Poultry Association roted to have the Standard of Perfeetion illustrated by profile or outline dravings. An attempt was made at that time to hare these take the place of symmetry. The first Stanclards of that year were illustrated with outline drawings but were soon abolished as us satisfaetory. 
Remember in judging symmetry that it is "the harmony of all the parts or sections of a fowl, riewed as a whole.

\section{WEIGIIT UF IBUN\%E TERKES:}

Weight is the next section under the scale of points and it is valued at 15 points. This section is of a good deal of importance whether the breeder intends to exhibit his fowls or whether he is raising them merely for commercial purposes. The Standard weights for Bronze turkeys are:

Adult cock ....... 36 lbs. Cockerel ........ 25 lbs. Yearling cock .... 33 lbs. Hen .......... 20 lbs.

$$
\text { Fullet ............. } 16 \text { 1bs. }
$$

In scoring tnrlieys the Stantard instruetions are to cut 2 points for every pound less than Standard weight, using one-fourth pound as the minimum.

For example, if àn adult cock weighs thirty-five and one-fourth pounds it would be cut one and one-half points (See Fig. 1.). Any one can easily see that a tnrkey which is not np to weight and is handicapped by a eut of one and one-half, will stand a poor chance of winning in close competition.

'l'hough many of the Bronze turkey breeders are exhibiting specimens weighing nearly fifty pounds and have been trying to get the Standard weights raised, it was not deemed adrisable by the last revision committee.

The market demands a turkey even below Standarel weight and they sell at a higher" price than the exceptionally large ones. While the large specimen makes a fine exhibition bird, there is such a thing as getting them so large as to be useless as breeders; there is little eall for them on the market except for use in large hotels, and they use them merely as "soupers."

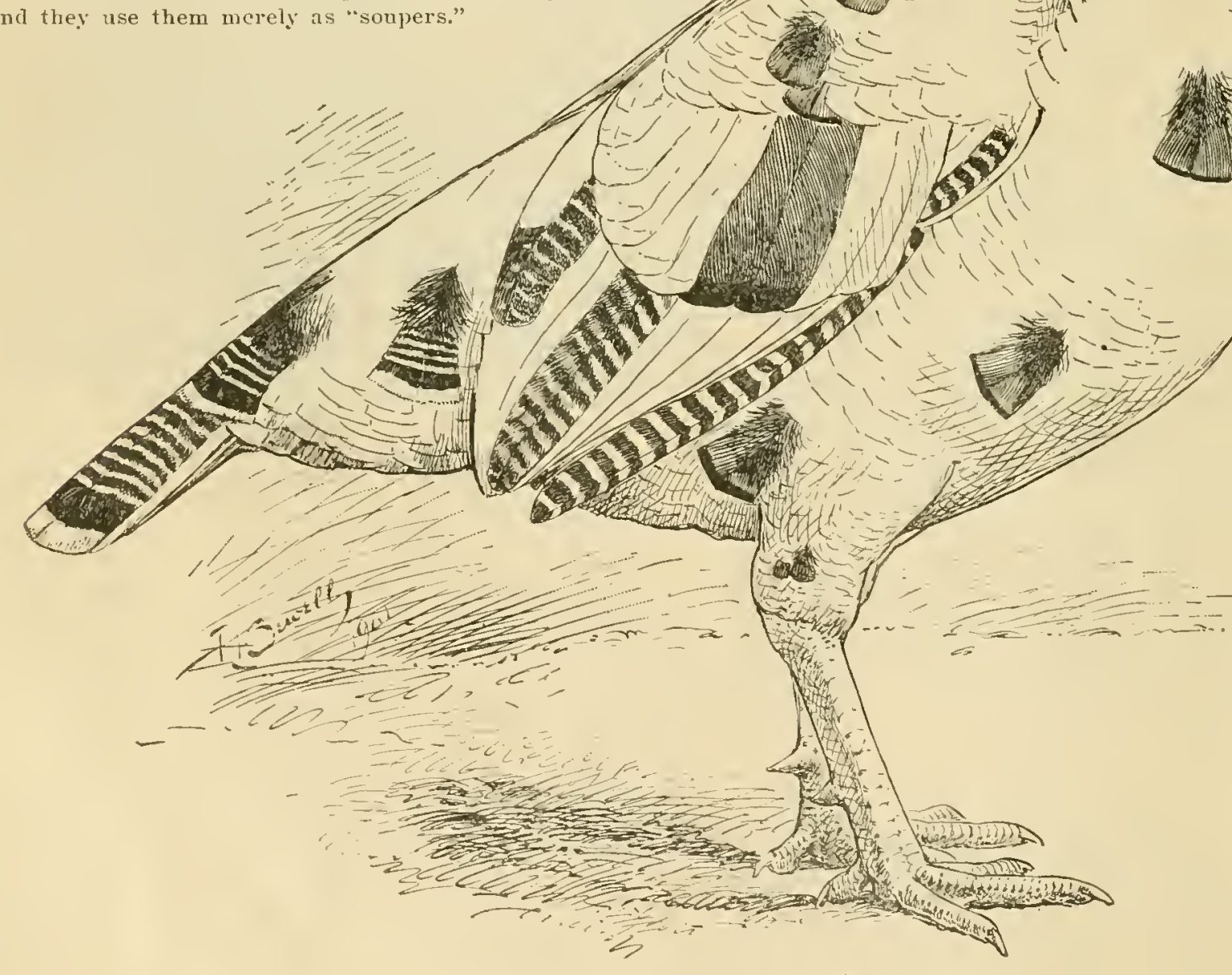

Ifleal or Standard Brouze Turkey Male

\section{(ONI)ITION}

This section is valued at four points, and refers not alone to the health of the specinen, but also to the condition of jis plumage. Of course a bird should not be shown uniess it is in grod health, and its plumage should receive careful attention. Turkeys should be handled with great care when getting them ready to send to a show, as they arc naturally of a wild disposition and broken wing and tail feathers and mnssed and crumpled plumage due to rough handling and lack of room are things that handicap a specimen and it will I fowl showing signs of disease such is roup, cholera, ete., should be debarred from competition. 'lhese diseases are contagious and the judge should see that any such specimens are rewoved from the show room to save other birds from being infected. If a bird shows signs of a

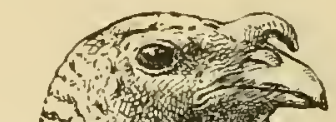
tin (i)

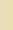

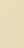
be cut for such defeets. 
cold or canker it should be cut at least onehalf point. It it is rough and dirty from careless handling it should be cut one-half point; if the bird is cut and bleeding from fighting or other injury the cut should be from onc-half to one. Specimens which are dirty and show that no eare luas becn giren them should be cut onc-half to one point.

\section{$11 \mathrm{EAD}$}

The head is valued at fire points, just the same as in the old Standard, and is usually good, both in shape and color. The Standard says that in shape the head should be: "Long, broad, caruuculated," and in color should be: "Rich red, changeable to bluish white." This section is generally good and it is rery seldom that we find a specimen that has to be cut and if we.do, it is usually for being a little too short or having as it is commonly called, a bulict head. If such a head is found it should be cut one-half to one point. If the beak is too long or straight or injured, a cut of one-balf is generally sufficient.

The eyes are included in the head section and should be "broad, clear," and dark brown in color. They were formerly linown as hazel eyes but the last revision committee seemed to think that "lark brown" was the better description.

\section{TIROAT ANI) WATTLES}

This scetion is valued at five points as of old, and is usually passed without a eut or discount, especially as far as color is concerned. 'l'he Stanclard calls for "Heavily carunculated." Once in a great while we see a specimen that is rather smooth in this section and it should be cut one-half to one, but such cases are very few.

\section{THE NECK}

The neck section is ralued at six points and is divided three for color and three for shape. In shape it should be long and curre backward toward the tail. In color it should be "Light, rich, brilliant bronze." Please note that it must be brilliant and show a bronze sheen and that the Standard says it must be "light." The bronze shading is not as deep on the neck as it is in some other sections and so it has a lighter appearance. It is very seldom that a neck bas to be cut; perhaps once in. awhile one will be found that is a little too long and straight, but not often. The color occasionally shades off to a brown on the back of the neck and if jt does cut one-half to one.

\section{THE BACK}

The back retains the same raluation as in the old Standard, ten points, but is divided differently as shape is now valued at four points and color at six points, while formerly it was dividad evenly, five for each. This section in a turkey, as in any other variety of fowl is of g:eilt importance, for without a well balanced back the specimen is of little value as a bleeder. In shape it shonld be broad and somewliat curred, rising from the neck and descending in a graceful curve to the tail. The color "from neck to midale of back, should be a light, rich, brilliant bronze, each feather terminating in a ni.row, black band extending across the end. From middir of back to.tail corerts, black, each feather having a brilliant bronze band extending across it, near the end."

We have heard some breeder's object that the Standarr does not give some definite length of back. This would be a pretty hard thing to do. In order to come up to Standard weight and still have a nicely proportioned and well balanced body, withont appearing too flat, the back would have to be of good length and we might be safe in describing it as "rather long." We must remem- ber that the shape value of this scction has been reduced one point and is now only ralued at five points. If the back is too straight, failing to show the curre above referred to. the cut should be from one-half to one and one-half. If the curre is too prominent, giving the bird

\section{Fig. A}

\section{POULTRY ASSOCIATION}

January 10, 1910 - Date

Official Score Card American Poultry Association

Exhibitor Samuel Smith

Breed Bronze Turkey Sex Cock

Entry 1 No. Band $100 \quad$ Weight $3+\frac{1}{3}$
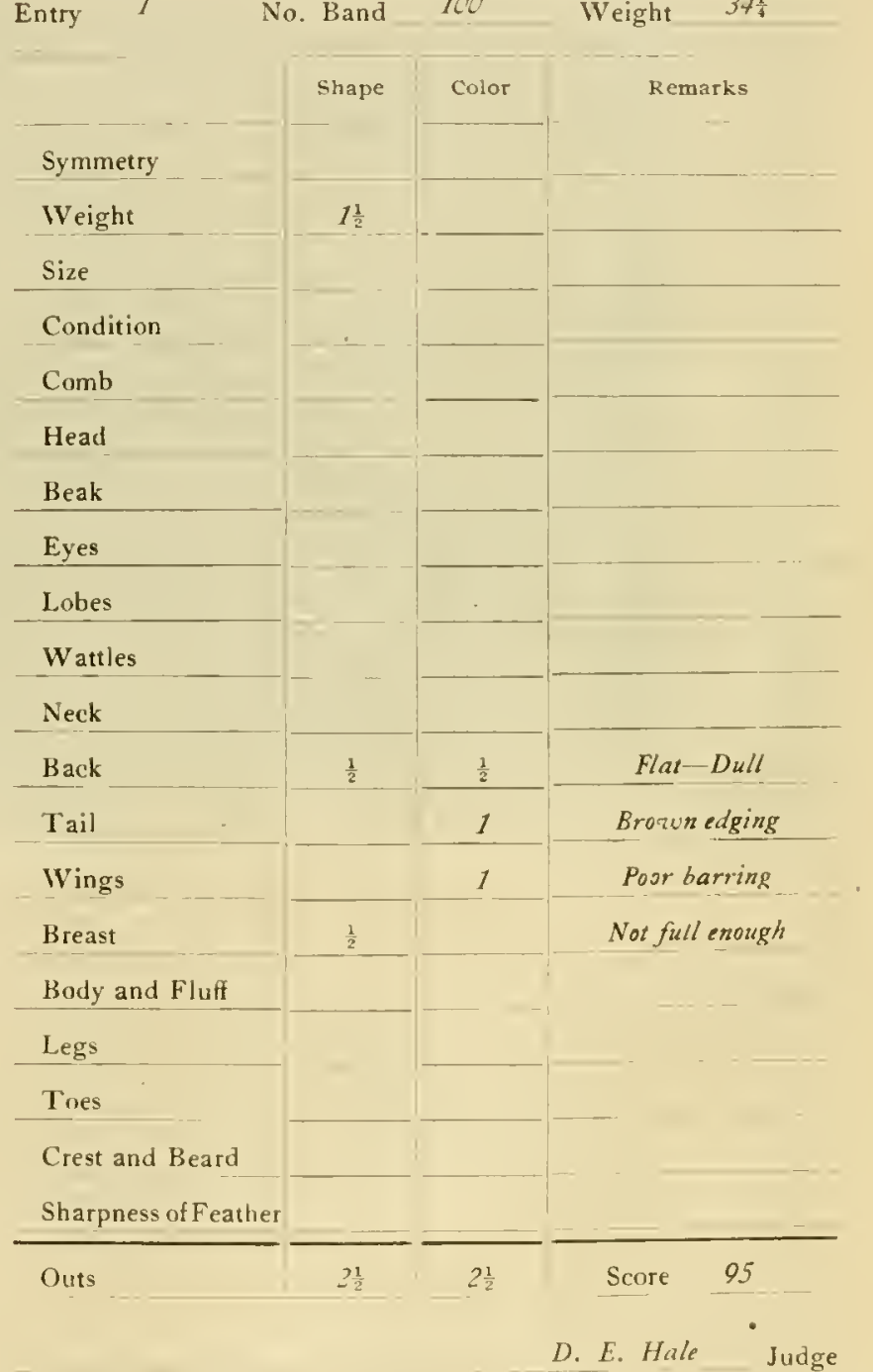

F. L. Bradford Secretary

Reproduction of Score Card, Showing Sample "Cuta" for Defects

the appesrance of having a humped back, the cut should be the same. If the back is deformed or crooked, the specimen will be thrown out of competition.

In color, if the fenthers lack the narrow black bands across the ends, the cut should be one-half to one. In the males especially a shading of brown will sometimes 
appear in this section. It generally is a narrow edgng just inside the black. When this is found it should be cut from one to two points.

\section{THE TAL}

The tail is another importint section and one in which the color defects are as prominent as in any section of the bird. It is now valued at twelve points, divided four for shape and eight for color, while formerly it was worth but ten points, divided four for shape and six for color. The valuations are the same as for wing and both are important color sections. The Standard merely says that tail should be "rather long." It should also be well spread, for a pinched tail on a turkey would. look as bad as on any other fowl. By studying Fig. 1 you upon exanining Fig. 1 that part of the tail is covered by the corert feathers. In judging the specimen the judge examines well down toward the roots of the feathers for sometimes they are found to be solid black under the corerts. Should this be the case the section should be cut one-halî to one and one-half points. Sometimes broad bands or bars of pure white will be found at the base of these feathers. Some breeders claim that this is caused by trying to breed too wide a band of white on the tail corerts and on the ends of the tail feathers. Too much "white blond" erops out at the base of the tail, and it will sometimes show at the base of the wing primaries.

Where we find these white bars at the base of the fealliers, the cut should be one-half to one. Where the barring is irregular on the tail proper the eut is one-half

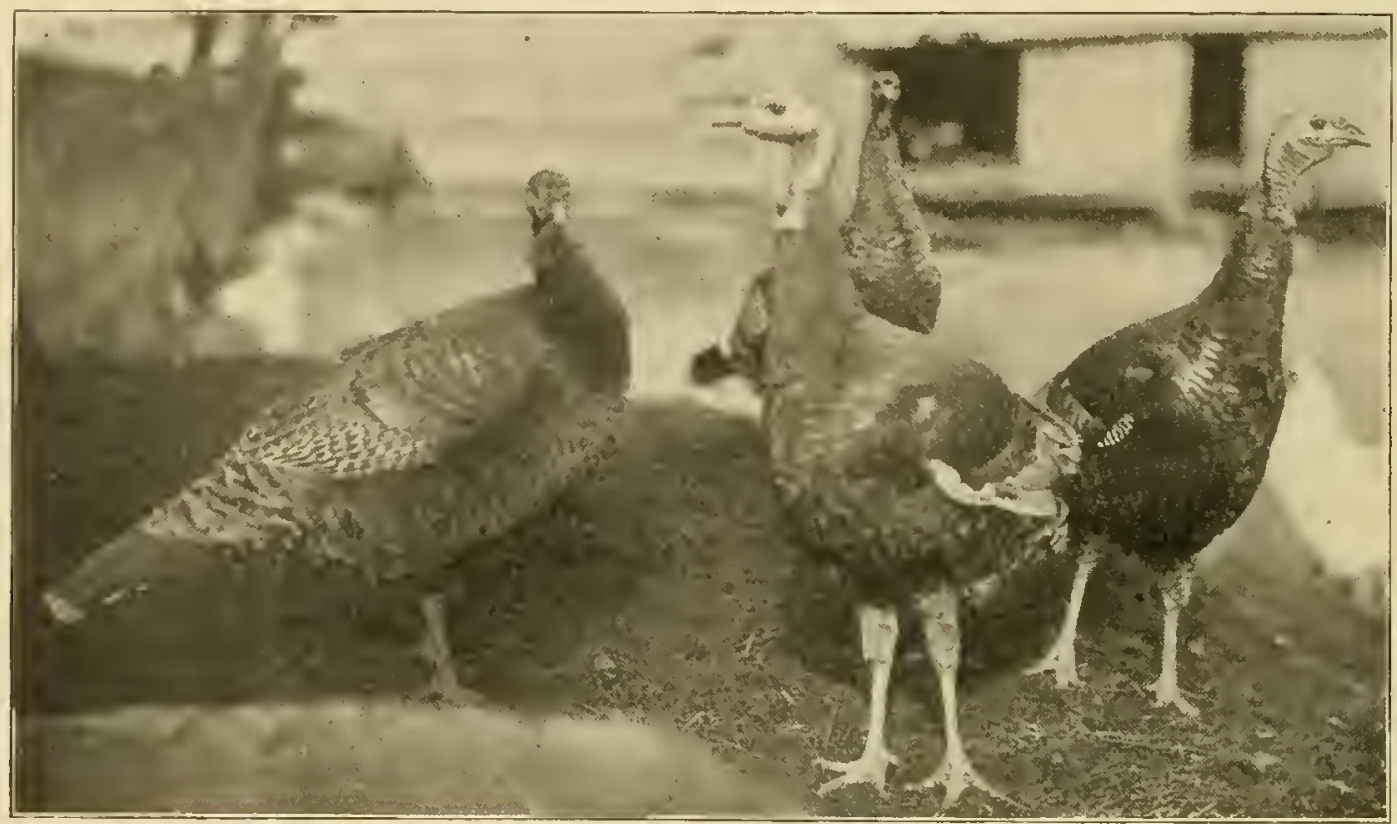

The Pride of the Farm

will get a good idea of the malkings which the Standard describes as "Dull black, each feather evenly and distinctly marked transversely with parallel lines of brown, each feather having a wide black band, extending across it near the end (the more bronze on this band the better) and terninating in a wide edging of white. Coverts. dull black, each feather evenly and distinctly marked transversely with parallel lines of brown, eacli feather having a wide black and bronze band extending across it near the end and terminating in a wide edging of white, the fewer larger coverts extending well out on the tail haring a little bronze on them. The more distinct the whole plumage throughont the better.

The black band near the end of the feather shonld be a sharp distinct black having a slade of bronze, and the white band at the tip should be a clean, distinct white and not a gray. When these two bands are sharp and distinct as they are on a well bred bronze turliey male. no prettier contrast ean be found on any bird. Shonld the white band be more of a gray than a white, it should be cut from one-half to one. The corerts should be transversely marked or barred with brown, ending in a wide black or bronze band, extending across the feather, with an edging of white.

While the ground color of the tail feathers is black, they should be well barred the full length. Yon will note to one and one-half. Where the white outside lacing is mixed with gray or brown the cut is one-half to one and three-fomths. Where the coverts fail to show a clear elging, the cut is one-half to one and one-half; if mixed with brown or dirty gray, the cnt is one-half to one and three-fourths. A tail that shows a decided edging of brown or red should be severely discounted in the show room and the bird should not be used at all in the breeding pen, for it is indicative of an outcross with the wild] turkey, and is not, in color, a pure bronze.

Fig. B on page 29 showing the outspread tail of a bird owned and bred by Mr. T. J. Bell, shows what excellent white edging is being bred.

This half tone does not do justice to the bird's penciling or barring, for it was much plainer and more distinct than in this picture.

\section{THE WINGS}

T'he wing section is another important one especially as regards color. It, too, has been raised in valnation, being now valued at twelve points divided, four for shape and eight for color, while formerly it was ralued at ten points divided four for shape and six for color.

It is sellom that we see a perfect wing. We wish again to call your attention to Fig. 1 and to ask you to study the markings of the wings. The Standard sava: 
"Bows, light, rich brilliant bronze, ending in a narrow band of black; prinaries ench feather evenly and distinctly barred straight across, with parallel bars of black and white througlout the length of the feather; secondaries, dull black, evenly and regularly barled across with. parallel bars of white, (the more distinct the better) the color changing to a bronzc brown as the middle of the back is approached and the white bars become less distinct: an edging of brown in secondaries being very objectionable; coverts a beautiful rich bronze forming a beatiful. broad. bronze band across the wings when folded: feathers terminate in a wide black band, forming irregular showing zignag tracings across the wing, the cut is one-hali to one and one-half. It the barring appears only on one sicte of the quill, the other sicle showing black or at mixed up muldy color, the cut should be onehalf to two. If the secondaries show a slight tracing or edging of white or brown, the cut shonld be one-half to wne, but if this edging is prominent enough to mar the beaty of the wing, the cut is one to two and one-half. If the coserts fail in the black band at the end of feather, rausing what would be termerl an unfinisherl wing, the cut is one to two.

In order to illustrate what good wing barring is, we

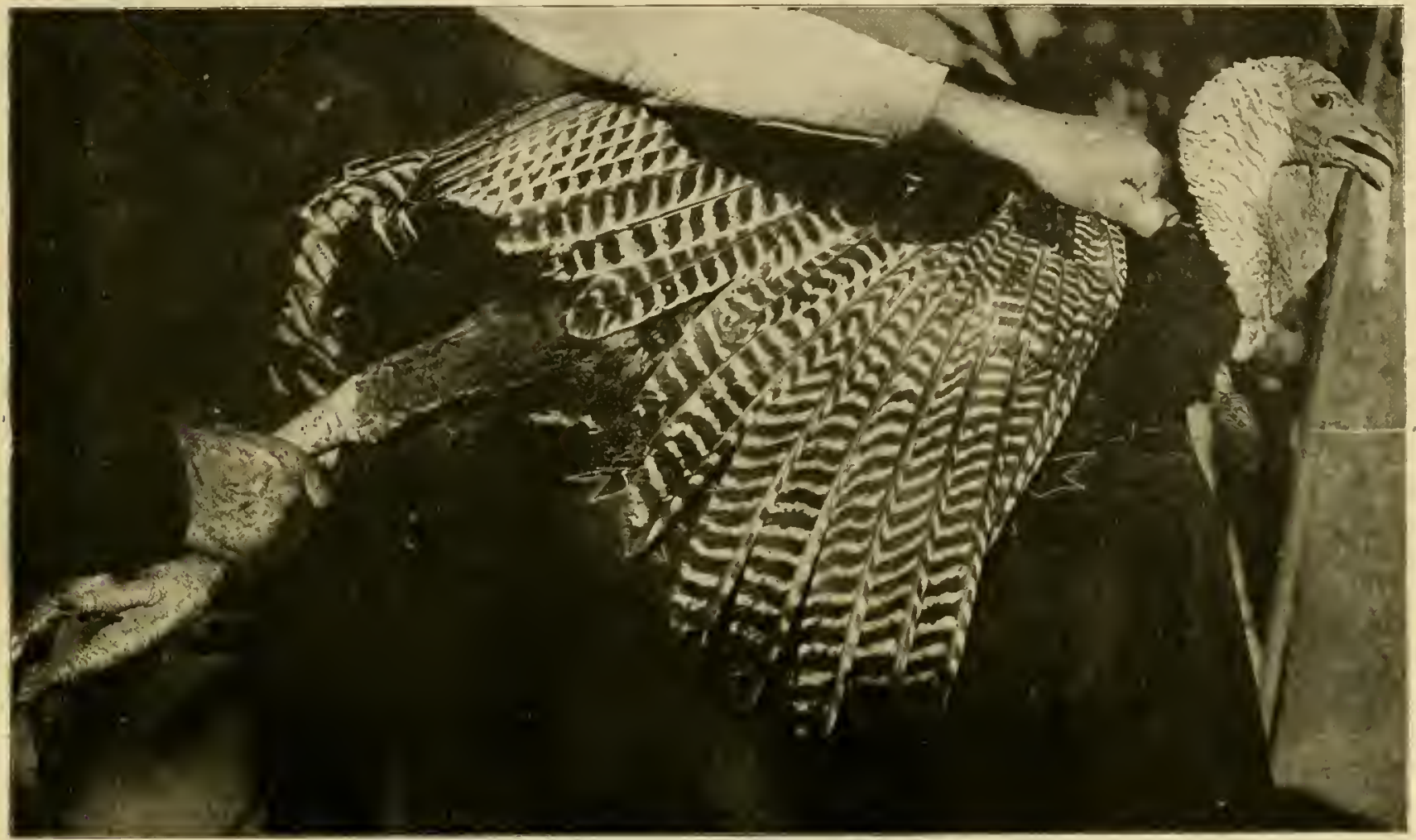

Fig. 2. Reproduced from photograph, showing Standard Barring on Wing of Bronze Turkey Male.

a glossy, ribbon-like mark, which separates them from primaries and secondaries. The Hight coverts are barred similar to primaries."

Note carefully the tracing of bronze on the wing bow. Up ncar the top the feathers are solid black, but as they approach the wing bar the bronze edging deepens, giving the wing when viewed in the sunlight the color of burnished bronze. It night be well to go a little farther and say that the last bar on the primaries and seconclaries slrould end with black. We should also remember that the barring should extend to the end of the feathers. We quite often find a specimen that is unusually good in color, especially in primaries and secondaries, execpt that near the end of the feathers the barring will stop and the last two inches will be solid black. When the wing of the male is perfect in color, except this black, mate with him females that show more white than black in their flights, and should you have one that has a wing with the last bar white, instead of black, she will be all the more raluable as a breeder.

In scoring the wing of either male or female, when this black aplears at the and of the feather, the cnt should be one to one and one-half. If the barring is call your attention to the half tone picture Fig. 2 on this page.

Note the sharp, distinct barring, also that it extends well back on the secondaries.

While the tips of the fight fenthers show as being black, we are reliably informed that this was the fault of the photographer and not of the bird, for they were well barred to the tips.

\section{THE BIRLANT}

The valuation of the breast section has been raised one point by the last revision committee and is now ralued at eleven points being divided, six for shape and five for color, shape valuation having been raised one point.

From a conmercial point of riew this is as it should be, for there is no part of the turkey that is more popular at onr national Thanksgiving feast than this section, unless perhaps, it is the well-known "drum stick."

This section is seldom passed withont a cut as it is very liable to be undereloped or a little too flat, unless the specimcu happens to be an old tom and fully dereloped. In shape it should be "Broad, deep, full and well 
rounded." In color it slould be "Light, rich, brilliant bronze; feathers on lower part of breast approaching the body, terminate in a black band extending across the end."

If the breast is too narrow or too flat the cut should be one-liaif to one and one-half. If it is too shallow or not deep ellough througli from the shoulder to point of hreast bone, the cut should be one-half to two. If the color fails in the narrow edge of the black, giving the surface a dull, clend sort of color, the cut should be onebalf to one and one-half. Should any of the feathers on the breast slow an outsicle edging of white the cut is one-half to onc and one-half.

\section{BOW ANI) FL(WE}

This section, the same as breast, has been raised one point and given a valuation of eleven points, being divided, shape six, color fire, shape getting the added point. The Standard description for shape of body is very clear, viz; "Long, deep tlrrough the middle, finely rounded." The color is given as "Body, black, beautifully sladed with bronze, but not so decided or so rich as breast. F'luff, black, each feather having a wide, brilliant, bronze band, extending across it near the end and terminating in a narrow edging of white." If the body is too short or too narrow, the eut should be one-half to two; if flat, failing to show a nicely rounded outline, the ent slould be one-half to one; if not fleep enough from back to base, the cut should be one-half to one and onehalf. If the keel is crooked, the cut should be one-half to one.

We should not adrise the amaten to breed birds with a crooked breast bone. While we read a great cleal about them being caused by the birds roosting too young and by being kept on a board floor and sereral other things, we are convinced that it is bred in them the same as any other deformity and we certainly should not use one for breeding if it conld be avoided.

The color of the body is usually pretty good; once in awhile we find one that loses its bronze and has a dull brown look and these slould be cut one-half to one. Sometimes gray tips are found, which should be cut from one-half to one and one-half. See that the forl has plenty of length back of the legs. If not well balanced and the bird has the appearance of liaving too much weight in front of the legs the cut should be one-balf to one.

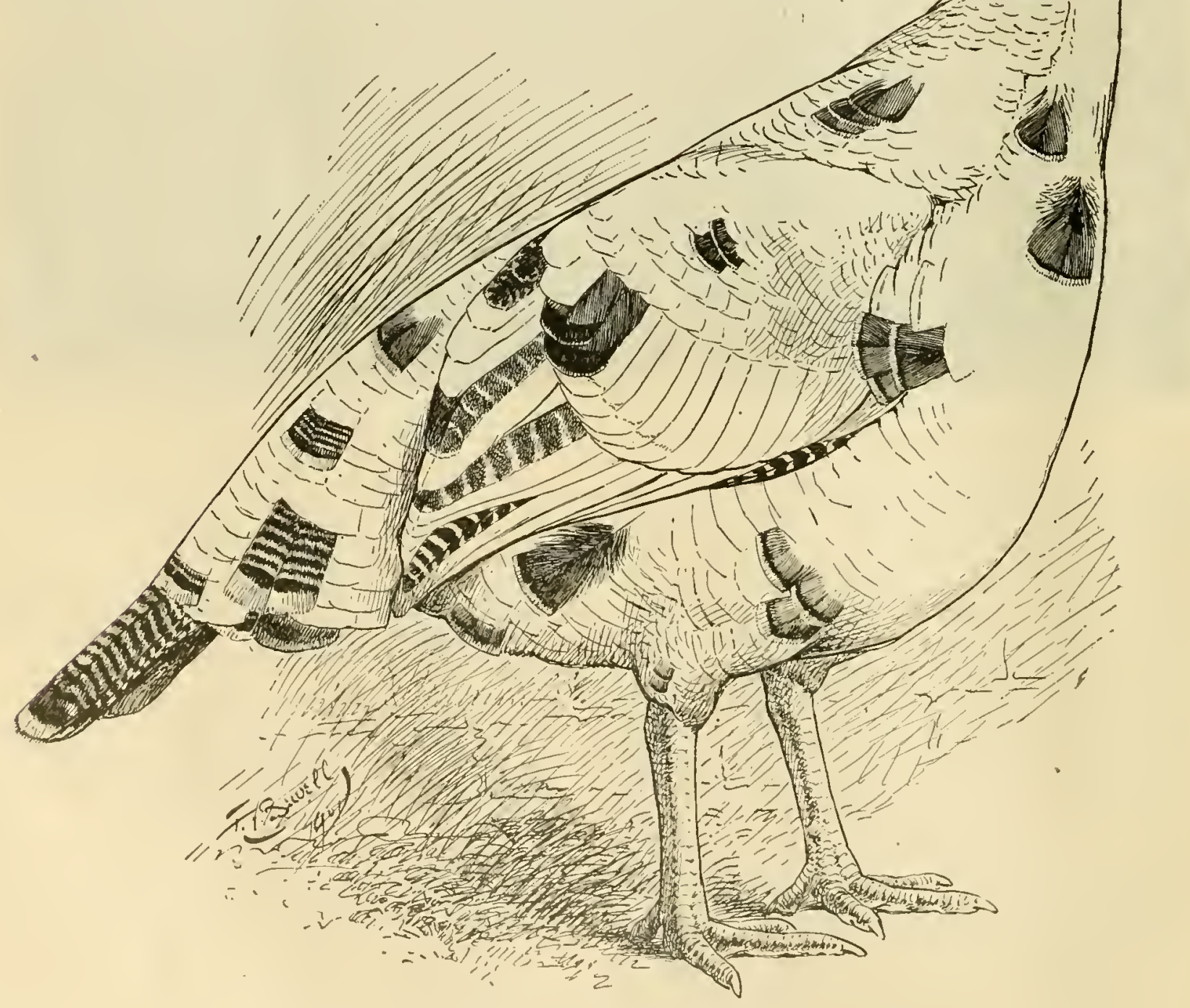




\section{LEGS AND TOES}

This section retains the same valuation that it had in the old Standard, but is dirided, three for shape and two for color. They should be, "Thighs, long, stout; shanks, large, long, strong. Toes straight, strong." Fig. 1 gives you an excellent idea of what a good turkey leg should be. Here we have a thigh that is of good length, and stont, the kind that carries lots of meat and muscle. The thighs should be the same as the breast, only less brilliant in shade. The shanks should be pinlish, in old birds, and in young birds will be dark, approaching black. They should stand well apart, giving the specimen a broad, massive appearance when rieved fron: in front.

'The twes should be straight and well spread. The legs should be as described by the Standard, of fair length so as to hold the specimen well up, but not so lon: as to make him look leggy or lanky.

If the legs are too fine in bone making the bird look fominine, the ent should be one-haif to one; if too short or too long, the cut should be one-lialf to one and onehalf; if too close together or knock-kneed, the cut should be one to two. Crooked toes should be cut one-half each. If the legs are faded, dirty or scaly they should be cut one-half to one and one-half; if oft-color they should be eut one-half to one and one-half.

\section{THE BRONZE TLRKEY INEMALE}

In Fig 3 is shown one of the best turkey drawings ever produced by any artist. Erery breeder that has inspected this chart conceded it to be the outline of an ideal female. Although $\mathrm{Mr}$. Sewell drew this picture several years ago, we have nerer seen any that could take its place.

It is not necessary to go into a detailed sectional description of the female, for she is similar throughout to the male, except being finer in bone and not so coarse looking. In regard to color the Standard says; "Plumage similar to that of the male, except edging of white on feathers of back, wing-lows, breast and body, which edging should be narrow in front, gradually widening as it approaches the rear. Beak, eyes, throat, wattles and shanks and toes sane as male."

A conmon defect in the female is a brown color that shows on the outer edge of white lacing on the feathers of the back and breast. When this is found it should be cut from one-half to one and one-half. The back of the neck is inore apt to show this than any other section and it occurs oftener in the female than in the male. We do not, of course expect as brilliant or bright a bronze in the female as in the male. Breeders by carefully mating together each year the best of the flock are improving the feniale to such an extent that it will not be surprising in time to find the same brilliant bromze on wings and tail coverts that we do on our best exhibition males.

If the amateur will study well the charts shown herewith, also how each section is valued and how the common defects are cut, he ought to be able to pick out his best exhibition specimens and be better qualified to select his brceders. 


\title{
TURKEYS - THEIR CARE AND MANAGEMENT
}

\author{
An American Wild Fowl that in Domestication has Been Brought to an Advanced Standard of Excellence and Serves \\ Highly Practical Purposes-Standard Requirements of Different Sections-Mating to Produce \\ Exhibition Specimens-General Advice on Care of Flock
}

\section{S. B. JOHNSTON}

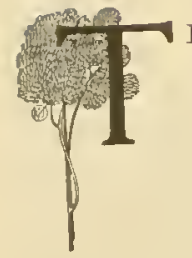

HERE are a number of turkeys bred in this part of the state, so that we are generally well acqnainted with the different varieties, althongh our work has been confined to the Bronze variety. There are six varieties besides the Bronze in the standard, namely the Narragansett, Bufi, Bourbon Red, Black, Slate and White Holland. Then there is a white sport from the Bronze that is nearly as large as that variety and that has more desirable featnres than the White Holland, which is the smallest variety in the Standard. The White Holland is a good bird, but is too small and will not bring the marketman as profitable returns as the Bronze or Narragansett. I believe fewer people raise the Black 'Turkey than any other variety, as it is not liked by shippers on account of black pin feathers. Bronze, White Holland or Buff Tnrkeys are easier dressed and pin feathers are not erident.

The Bronze Turkey is the largest of all varieties. It matures quickly and by the holiday season will attain its fnll weight. It is docile and easily kept at home. It is said by some that the Bronze Turkey is not easily kept at home, but I have found that turkeys of any variety not having proper care will stray away. In hardiness and vigor there is no rariety that can surpass the Bronze when properly bred. The wild turkey is so near in color to the Bronze that by earefully introducing new blood by wild hens the breeder can get hardiness and vigor un: equaled. Turkeys that are hatched in April, Mlay and June will begin laying the latter part of Narch or the first of April the next year. I believe that all varieties of turkeys in the same latitnde begin laying about the same time. In this latitude they begin about the first of April more generally than in March. There seems to be always a good demand for turkeys of all varieties. It takes the Bronze variety about three years to get its full weight-in other words, to get its heariest weight, while most other varieties attain their full weight by the second year. There are more Bronze Turkeys raised than all other varieties combined, which fact is proof enough that the Bronze has more good qualities than any other variety.

\section{RANGE AND HOUSING}

Tnrkeys do not do well in small and crowded quarters. They can be raised to some extent on a small range, bnt such specimens generally are stunted in size and of poor color, just as is any other stock that is ill-kept. When the turkey was first fonnd it ran wild in the forest, hence the love of range is ahout its first instinct and it will attain nearer perfection in size and color when it has freedom. Some writers advocate the housing of turkeys, but in my experience I have not fonnd this best. I hare learned that a turkey hen can take care of its yonng better that either a domestic hen or myself, as the turkey mother seems to understand the little poults' chirping and knows what they need. I have tried raising turkeys in coops and pens, keeping them close to the house, but with poor success. When the season is not too severe, turkeys can be given the run of the place, and if they have good quarters in which to roost at night, under bushes or something of that lind, and are looked after dnring the day for a few weeks, they will not need much food, bnt will do better and grow faster than those kept close to the honse and fed from five to six times a day. Tnrkey's raised in this way are less trouble, have better plumage and are more vigorons, and in the fall when the corn is being gathered they can be toled to the house to roost. Turkeys kept close to the house and not extra well fed will stray off, hence the advantage is all with the one who raises his turkeys away from the house.

I have found that a roost built close to the ground is of great advantage to young birds that are growing fast, as it often happens that promising youngsters are injured in flying from high roosts. I beliere that a shed open to the sonth and closed to the north, east and west is of great adrantage in severe weather in keeping tnrkeys dry and free from drafts. Snch a shed makes a good feeding place when there is snow or mnd, and would make a good roosting place if the tnrkeys could be induced to roost in it. The great trouble is to keep them from roosting on top of the shed, but this can be prevented by rnnning a two-foot wire netting around the top. I should not attempt to raise turkeys on one or two acres of ground, but with proper care a forty-acre farm will give ample forage for five hundred birds. In these days it is a large flock that contains more than one hundred turkeys.' They do best when divided into flocks of abont fifty.

\section{- MATINI BLON\%E TURKEYS FOR PRIZE WINNERS}

If I were asked the most essential point for breeders. I should say first of all vigor, then size, then fine markings of plumage. The fancier must consider size, becanse nine out of every ten want size first. It is not the rule, however, that the biggest turkeys are the highest scorers, no matter how well they may be bred. To improve size, weight and markings, select the finest marked tom of good big bone, with typical carriage, strong and vigorous, and mate him with the largest hens possible, no matter if they are not so well marked. Then the next season reverse the order and if you are so fortunate as to get well marked birds of both sexes, mate them in the following manner: For the females, select tall, rangy birds, with long, deep bodies, broad backs, and full rounded breasts, with as big bones, feet and legs as possible. In color, the head and wattles shonld be a rich red, but nnder different circumstances the head is changeable to bluish white. The plumage of the neck and breast should be a rich, lustrous bronze, the breast and back in front of wings showing a narrow lacing or edging of gray. The back is somewhat darker in color, as it shows a narrow black band across the feathers as they near the lesser tail coverts, these ending in a white or gray edging. The primaries and secondaries of the 
wing feathers must be as near Standard as possible. I take it for granted that every breeder has the Standard, for it is the book of autlonity, and sets forth clearly the disqualifications. I would say, however, that the wlite or gray bars should be about three-sixteenths of an inch in width with the black or brown bars about three-eighths of an inch. 'They should be even and straight across the feathers. The tail should be long and black, with pencilings of light brown aeross the feathers, the featliers ending in a broad, black band with an edging of dull white coming right up to tlie black. The feet and legs sliould be darl;, approaching black. This is of less importance in the females than in the male.

The tom has more influence on shape and color of offspring than has the female. lle slould be as near perfection in carriage and color of plumage as it is possible to get. He should be of medium size and of good vigor. In $\mathrm{my}$ opinion, the Standard makes a mistake in calling for larger hirds, as this detracts from their profit as egg-produeers. A good vigorous tom will mate with eighteen or twenty hens. Is to the best age for breeding fowls, I use a twoyear-old male and female one year old, or vice versa. Yearling turkey hens will lay more eggs than an older hen, but the two-year-old lien's eggs will hatch stronger noults. Hens are profitable as a general thing until they are four years old. I have kept some good layers until they were six years old. As a rule turkeys are not profitable after they are four years old. Three to four-year-old tom turkeys usually beeome cross and irritable and are dangerons to have about where there are children.

I have the best suceess with pullets from sixteen to twenty pounds, and old hens from eighteen to twentythree pounds. They lay more fertile eggs than larger hens, are nore active and healthy and make better mothers. Turkey hens do not all commence laying at onee, and generally by the time the first layers want to sit the last ones to lay are ready to begin. Turkey hens should be earefully fed at the laying season if fed at all, as they will pick up on the range nearly all the food they need. If allowed to get too fat they will not lay until late. It is a good plan to feed meat two or three times during the month before you want them to lay, as it will hare a tendeney to make the eggs more fertile. Turkey eggs as a general thing are sure to hatch. I have had hens lay as many as four clutches of eggs in a season. Turkey eggs will hatch in twenty-eight days, but with medium sized turkeys it usually requires twenty-nine days, and eggs from very large hens frequently run orer to thirty days. I have an eight-foot fence around about two acres on my home place that I use for the laying turkeys in the spring. I use boxes and barrels turned on the side for nests.

\section{AT IIATCHING TINE}

One should be rery careful in setting turkey hens, as they are of a wild nature. It is best to try a hen, if one has valuable eggs, by giving her a few nest eggs for a day or so, then at night taking the nest eggs out and putting the good eggs in. Be careful to have the bottom of the nest firm and solid, so that the eggs will not roll about. Hare the nest so formed that it fits the shape of the hen. In this way the eggs will all be the same distance from the hen's body and receive the same amount of heat. Sprinkle the eggs at sitting time and two or three times during hatching time with Lambert's Death to Lice, or some other good insecticide. If your hen is genile you might take the poults out of the nest as they hatch. This leaves more room for those that are to hatch. If the hen is inelined to be irritable, it is best to leave her alone, as sle may get excited and trample on the poults. I have successfully used incubators for hatching turkey eggs, but wlien it comes to putting the poults in the brooders it is another matter. It is all right to hateh them in an incubator if one has hens to which he ean give the young poults to be raised. I never feed my voung turkeys until they are twenty-four to thirty-six hours old. 'They are first giren grit, then some oatmeal or groats. I use very little soft food. When giving soft food it is best to mix it with sweet milk and give only what they will eat up at one meal, as turkeys should never have sour food. Give table scraps and any green food you may have. Cottage cheese is a good food for poults and is particularly good with eut onion tops, salted and peppered to taste. Oat groats are highly reeommended as a dry food for poults. Give millet seed, kaffir eorn, wheat and then eracked corn. Feed these grains alternatingly.

\section{AT MARKETING TIME}

I have fonnd that winter feeding differs from summer feeding, as in cold weather poultry needs corn on account of its heating and fat-producing qualities. Turkeys on the range in walm weather do not require much corn. If one has a large range the turkey crop is almost clear profit. Turkeys intended for market should not be fed heavily until within about two weeks of selling time, when they should be giren all the corn they will eat, with a ehange of food as often as possible so that they will not tire of the corn before they are fat. Make corn their main foocl.

The average price for turkeys on the market is eight eents per pound. When stockmen get five cents per poind for hogs and cattle they make a good profit. It does not take anything like the amount of food to produce turkey meat that it does to produce cattle or hogs, and it is very seldom that the turkey grower gets less than eight cents per pound. On the other hand, it is seldon that the cattle grower gets more than four cents per pound for his beef or pork. When turkeys are properly "aised they are a benefit to the crop instead of a waste, as they destroy numerous insects. In California turkeys are rented out to men who have vineyards, who turn the turkeys loose among the vines to destroy insects. Turkeys do not require to be fed on a grain ration until withir. a few weeks of marlieting time, as they get their living from the gleanings of the field. In this way they get a large frame, which the grower can fatten when selling time conies. Turkeys should be fed away from other poultry. Sandy or gravelly land is the most suitable for turkey raising. Low, swampy land is not desirable, as it creates rheumatism, to say nothing of the filth. 


\title{
SUCCESSFUL TURKEY RAISING
}

\author{
With the Minimum of Labor-Laying House for Turkeys-Hatching the Poults-Housing Turkeys with Poults-Feeding \\ Young Turkeys-Roosts for the Young Birds-Shipping Crates for Pairs, Trios and Pens
}

\author{
MRS. M. L. SINGLETON
}

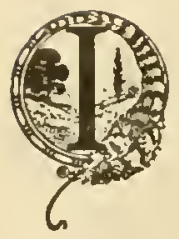

AM AWLRE that no two breeders manage their turkeys exactly alike, in fact, there are no iron-clad rules in turkey raising. Our surroundings differ so from those of others, that it is useless to formulate rules that would we impossible for them to follow, but there is one safe rule for beginners. No matter wliat your envixonments may be, start with the very best stock you are able to buy. If you hare money encugh to buy a good pair only, do not spend it for a trio or pen. If you can spare the money for firstclass birds, of course a trio or pen is desirable. To the thoroughly equipped breeders who have years of experience behind them, my methods will appear crude, doubtless. It is not for the breeder of experience that this article is written, but for those whose advantages are not great and who must struggle perlaps for years to gain the knowledge that will make them successful turkey raisers.

I learned several years ago that I had neither the time nor strength to follow the hens around and hunt their eggs in fence corners and hedge rows. so I had a laying house built for them. It is not a very elaborate affair, but it accommodates them very comfortably. A week or two before I think it tinje for them to hunt nests, I have them driven every morning into this house. In this way they become accustomed to going in and usually by the time they begin to lay they will go without being driven. When the turkeys lay from twenty-five to thirty egg:s, I set them under domestic hens, putting nine or ten under each hen. We find that there will be as Inany poults as one turkey hen ought to carry. of course you have to use a great many domestic hens where there are many turkey eggs to hatch, but it pays, I think, as they hatch so much better for me than do the turkeys. I do not set the first turkeys that get broody, but break them up and let them lay a second clutch. By the time the first turkey eggs have been incubated two or three weeks, the last hens will probably be getting broody.

\section{SETTING TIE TLRKEY IIEN}

In the meantine, I arrange my turkey nests, which are empty barrels, as I consider them among the very best nests. I saw out two or three of the stares about half the length of the barrel, that is, just below the middle hoop. I stand the barrel in the corner of one of my poultry houses with the open end up, because 1 think setting the eggs on the ground causes bad results. By naking the nest on the closed end of the barrel the eggs do not come in direct contact witl the damp ground, and they are yet near enough to obtain sufficient moisture Tack an old piece of carpet or gunny sack on the barıel over the opening and another over the top. Put in a lot of new straw and shape it into a solid, but rather shallow nest, and it is ready for the turkey. In the evening 1 remove her from her old nest and putting her gently in the barrel, drop the eurtain over the opening. I have previously put a few chicken eggs in the nest so if she is restless and inclined to stand up at first, there will be no harm done. The second day 1 raise the curtain and put food and water near the barrel, but if she does not come off, I let her alone for a day longer, and if she still refuses to come off, I lift her out. After she has eaten, I see that she goes back on the nest. When she has become accustomed to it, I lift the curtain up so that she can come out into the poultry yard and dust and pick around, alway's being careful to see that she goes back ou the nest. I arrange a number of these nests in the different houses to accommodate the different broods that come off. $\Lambda$ day or two before the little ones are due to hatch, I remove the egrs from one of the ehiclien hens, putting them under the turkey hen. When the little poults appear she is just as proud of them as though she had done all the work of incubating. As the little poults get dry and strong, I remove them to a flannel lined basket in the house. When erening comes, if the turkey is a very gentle mother, I carry them back and let them remain with her, as the warmth from her body strengthens them, but if she is a foolish old hen, I wrap the basket warnly and keep them in the house. When they are all dry and strong enough, I remove the mother turkey and her little ones to their future home. It is this home I wisl to tell you about most particularly.

\section{HOLSING TILE TURKEYS AND POULTS}

1 do not remember to lave read an article on turkey raising in which the writer dicl not suggest that a nicc, shady orchard was a desirable place for turkey coops. Now I admit an orchard is all right, provided it is located where you ean run out and look after the young turkeys at all times, but when one has all the work of a large house on one's shoulcler's and cannot get any help that is worthy the name, then I say most emphatically, don't. Here at Elonhurst is a large, shady yard at the west side of a building which has a porch almost the full length of the dining room and kitchen. A door opens out of each of these rooms on the porch. At the end of the porch is the pantry, which has a window in the west side, so if $\mathbf{I}$ am in either the dining room or kitchen, I can step out on the porch and see my turkeys, but if $I$ am in the pantiy, I can look through the window and see them, for it is in this side yard under the elm trees that my turkey coops arc placed. "Turkey coops in the yard!" I hear some housekeeper exclain. Ies, for my turkey coops are very lscat affairs and do not detract very much from the beauty and neatness of our yard. The coops are renewed each year, that is, I turn the last year's turkey coops over to the chickens and get new ones, because for some reason my turliey's always thrive better in new coops. 'I'hese coops cost only twenty-five cents each and a little work, for they are dry goods boxes sawed slanting, so that they are only about half as high at the back as they are in front. There are boards nailed on to extend over the front and rear. The lower boards are taken off the front of the coop and battens nailed on for t]e door, which slips back in place and is fastened with a wooken button which is just above the door. About six inches above the door another board is removed and scleen wire nailed on to rentilate the coop.

\section{FEED]NG AND CARING FOR POLLTS}

Now we lase the turkcy hen and her brood in a nice new conp under the eln trees where just enougl sunlight 
fitter's through to keep the ground dry, and not enough to hurt the teuderest poult. 'The next thing is to feed then. For the first day or two I give them nothing but light bread soalied in new milk, and pressed as dry as possible, with plenty of black pepper sprinkled over it. After that I feed them almost entirely on egr corn bread soalied in sweet milli, in which is mised raw egg. Right here I want to say, thele is nothing better for young turlieys than raw eggs. I learned several years ago that they are fin superior to boilerl eggs. I know that curd

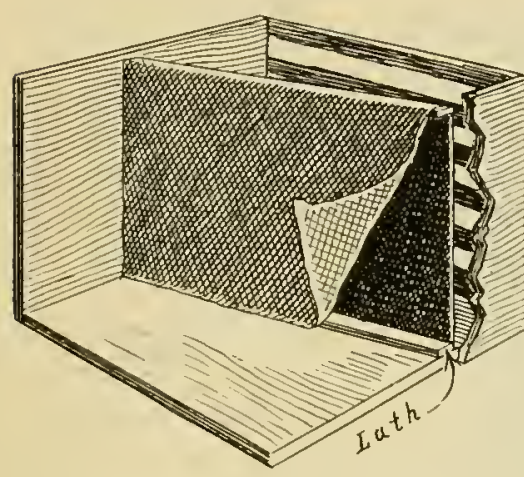

Fig. 1. Coop for two turkeys, showing lath at top, over which the cloth partition hangs, and the lath at bottom to which it is tacked. or clabber cheese is highly recommended by a great many persons, but I have found it a very injurious food for poults. I have beliered this for several years, but nerertheless, I commenced to feed sparingly last spring, and in less than two weeks I Iost five or six poults, and in every case but one I found the curd packed in the entrails. The other case was enlargement of the gall blarlrer, caused from indigestion.

Before putting the lien and her hrood in the coop, I coser the bottom with hay or straw, otherwise there is danger of the hen injuring herself from slipping on the boards. I once had a valuable turkey almost ruin herself in this way. 'The young ones, however, get injured much more easily on the straw. I leep the mother and turks in the coop for a day or two, unless the weather is very mild, and then I stake them out in an open place in front of the coops. T'his is done by tying a stout twine, such as fleece or wool is tied with at shearing time, to a short stake and driving the stake eren with the top of the ground. I ineasure the twine so that it will not be long enough to wrap arouud any tree or shrub, but near enough to the coop so that she can go in, but not around it. The string I tie on the leg, just above the foot. The hen will work and pull at the string for awhile, but she soon becomes accustomed to it, and when I take her out to tie her each morning she seems perfectly satisfied. This way has a great many advantages to me over the old way of putting them in a pen in the orchard. In the first place, the hen cannot kill the poults by jumping in and out. Secondly, they are right in sight, where I can gire them my personal attention at all times. Third, if a rain comes up, I run out, untie the hen and put her inside the coop. The young ones rush up for the food I give them and I put as many in with each hen as I think she onght to have, because you see I have several of these families in the yard and one mother is the same as another to them. By the time the rain comes, the hens with their broods are all safely housed, for it only takes a few minutes to attend to all of them. Fourth, by the time I give them their liberty, which is not till the poults are three or four weelss old, they have become accustomed to their roosting place, and the flocks are usually rumning together. The hens nerer separate, but all come in at night, bringing the whole drove with them. It is very seldom that they fail to come up, but if they do, I go after them and drive them up, because if they form the liabit of staying out, it is alnost impossible to breal 1)en. When they outgrow their coops and show signs of wanting to fly up to roost, I drive them into the turkey house, which is well ventilated, where $I$ have roosts made about two feet from the ground. I do this for fear of sudden rains in the night, for I an not strong enough to get up and carry turkeys in ont of the wet. I used to do such things in the past when my coops were kept under a shady tree in the orchard, but I realized that it was only a question of time when I should be compelled to give up the business entirely, or keep the turkeys where they could have my personal attention at all times.

When they are a few weeks old I feed them any small grain that I have, but the principal food is corn chops rampened just sufficiently to cause tlue fine part to adhere to the coarse. As they get older and until they are sold, they are fed almost entirely on corn. They must be well supplied with grit and oyster shells. When I first commenced to raise turkeys in such close quarters, I was told by all my neighbors that I would stunt them so that they would never recover from it, but as I raise the heaviest turkeys that have ever been raised in this part of the country, iny friends have quit talking.

I have been asked what preparation I give my turkeys for the show room, and my answer is, none whatever. From the time they are four or five weeks old until they are shipped to customers, they have the range of a onehundred-and-sixty-acre farm, and as soon as they are old enough to withstand the hard rains at night, they are made to roost outside in the open air. If during the winter we have deep snows, and protracted cold spells, we drive them into the barn and allow, them to roost there until the weather moderates. Nlanaged this way, there is no danger of them contracting colds and roup when being shipped a long distance.

\section{SHIPPNG CRATE FOR TURLEN}

Seeing the forlorn and bedraggled condition of turkeys shipped in pairs and trios to our station, made me wonder if the turkeys I shipped to customers looked the same when they arrived at their destination, and $I$ determined to devise some means of preventing them from picking each other and breaking their feathers while on the journey. The crate $I$ use is my own invention, as I have merer seen one anything like it, and while it is a very simple affair, it answers the purfose admirably. I use narrow clothlined crates for shipping turkeys,

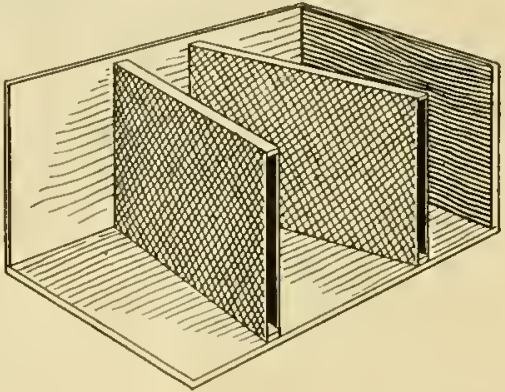

Fig. 2. Showing coop for trio, with cloth partitions in place. making the crate for a pair just a little wider than for a single bird, and for a trio a little wider than for a pair. Any style of crate will do, but the ends should be upright pieces so as to have something to nail partitions to. In maling a coop for a pair, after the frame is made and before it is lined, nail on two laths lengthwise of the crate, one the width of a lath below the top, the other against the bottom. Nail then firmly to the upright piece at either end. These laths are just slanting enough to show the space at one end to be about twice the width of the other. When you hare the laths firmly in place, take a piece of your lining twice the depth of the crate, drop it over the top lath, tacking it firmly to the floor on each sicle of the bottom lath. Now you have a good, firm 
partition, one that will sway gently with the motion of the birds, but keep them apart as effectualiy as a stone wall. If you wish to ship a male and female, have the space on one side of the partition a little wider than the other sidc, as the male is always broader across the back. Make it just wide enough for them to rise up and sit down comfortably. When putting them in the crate, place the tom with head toward the wide space at one end and the head of the hen toward the wide space at the other end, haring their heads at opposite ends. There is no danger of figliting, and the space being wider at one end and narrowing down at the other, there is no chance for them to turn around, which I have seen them do in a narrow crate that is the same width. In shipping a trio, follow the same general directions, having the wide end of the wide compartment and the narrow ends of the side compartments at one end of the coop, and at the other end, the narrow end of the center compartment and the wide ends of the side compartments. Have the middle space somewhat larger than the side spaces and place the tom in it, with a hen on either side. I beliere the same plan could be followed in shipping a pen, making the erate wider and adding two more partitions. The crate must not be lined until the partitions are put in, because there is no room to nail.

No matter low you raise or ship your turlieys, be honest in your dealings with your customers. In corresponding with them, describe your birds honestly, sending a tail, wing and covert feather. If your birds are well marked, the custonier can tell it by the feathers, but they liave to depend on you for correct weight, shape, etc. Remember always, the golden rule and judicious advertising are the only safe rules to follow in poultry culture. If you do not sell all your birds this year or next, you will some tinie, and if you do, you will not be ashamed to look your customers in the face if you should meet them.

\title{
BREEDING MAMMOTH BRONZE TURKEYS
}

\author{
Selecting the Breeders-Setting the Eggs- What to Feed at Different Stages of Growth-Remedies for the Dreaded Blackhead or Cholera- \\ Hints on Turkey Rearing from One Whose Experience Covers More than a Quarter of a Century
}

\section{JAMES E. I.OHD}

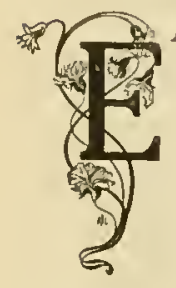

ARLY in the spring of my eleventh year my father sent me to an adjoining farm on which our family was to locate in a few weeks, my duty being to stay with the turkeys, to watch for their nests and to gather. their eggs. If my memory serves me well, this was my first responsible share in the management of the flock.

The March winds vere fierce and cold, but with undiminished interest I resumed the task each morning. The flock was made up of practically all the breeds and crosses known at that time and their wild natures were in strong contrast with our stock of today. I remember following one of those cunning creatures for the greater part of a day, but she finally eluded me by taking wing and alighting in a woods nearly half a mile away.

Two years later I was sent to a distant school. I recall distinctly the heartache I experienced in parting with "Old Yellow," a gentle house turkey that was all my own. The frequent allusions to this old bird in $m y$ correspondence with my mother attest my fondness for this part of farm life, which though interrupted from time to time, has becn resumed as often with all the ardor of those days.

Raising fancy stock was not very general then and showing was not even thought of, but our turkeys were sent to market in prime condition, were neatly dressed and sold at a premium even at that early date.

Improvement in blood was first suggested to the writer twenty ycars ago when he receired a present of a number of beautiful Bronze Turkeys from a friend in Vermont. They formed the nucleus of our present flock.

The old tom became a wonder in intelligence and he was taught several tricks. At picking one's pocket he was an adept. While showing off one day he stumbled and his neck was broken.

From time to time the best blood obtainable was secured, with the result that our birds were sought by ex- libitors and many prizes were won at leading fairs. Then we decided to show our birds, with results so gratifying that since 1902 the greater part of our stock has been sold to fanciers and breeders.

\section{SELICTION OI" BREEDING STOCK}

IIuch may be written on the selection of stock for breeding. Somewhere I hare read that it is easier to breed a turkey up to the requirements of the Standard than any other variety of poultry. I am not prepared to say whether this statement is true or not, but of one thing I am positive. Nerer yet has there been a perfect specimen of Bronze Turkey taken from the show room, and so long as this is true none of us needs to be less earnest in his efforts.

It has been our practice to keep as near the Standard as possible, size being the first requirement, shape next and color last. The defects in the female we try to overcone with the male, wlich must be good in all sections.

Fanciers should bear in mind the fact that the larger part of our turkeys goes to flocks bred for the market, and that in order to furnish satisfactory breeders we must aim to have birds of large size and those that mature early. To produce this result, select females of large frame and mate them with a cockerel, the largest and best of the breed that one can afford.

Lately pullets are coming more into faror. They lay earljer and lay a greater number of eggs than hens, make quite as good mothers and are less wily.

It is also desirable to have the broods off reasonably early. A few days give the early poults a long lead over their later fellows, which is as great an advantage to the market man as to the fancier.

Bear in mind that the male is one-lialf the flock, therefore do mot stop at a few dollars for a tom that suits. An undersized tom from a standard-bred fowl is to be preferred to one overgrown where the quality of his ancestors is mnknown.

The matured toms are often too heary and unless 
one can give then closer attention than is customary, the heus will be injured by them. It is a safe plan to keep sucli old toms apart from the flock, except when they can be watcher. They are a necessity in standard flocks, but it requiles a great anount of patience and perseverance to be successful with these extremely large siles.

It is a safe rule to place one tom with ten to fifteen hens. It sometimes happens that a raluable tom is not inclined to mate. This difficulty may be orercome by securing anothel one, preferably smaller. When the two meet in the flock, jealousy will open the eyes of the old bird to his duty.

For many reasons the hens should be induced to lay near lrome. Ours are so domestic that it is not unusual for them to nest in the buildings and often one is found in the hay loft. Collect the eggs each day, place them in a cool room and turn them every day or two until wanted for setting. The hen should then have a thorough dusting with some good lice powcler. As a heavy turliey hen is liable to break the eggs, it is better to liatch them under common liens. I'ut a few china eggs under the turkey until such time as the poults arrive, then slip one or two of the little ones under her orer night and by morning she will be in a mood to mother the whole brood. 13y another day they will be ready to be taken to the field, at which time they should be carefully dusted. We have found one application sufficient for the season, but it may be necessary sometimes to apply the powder several

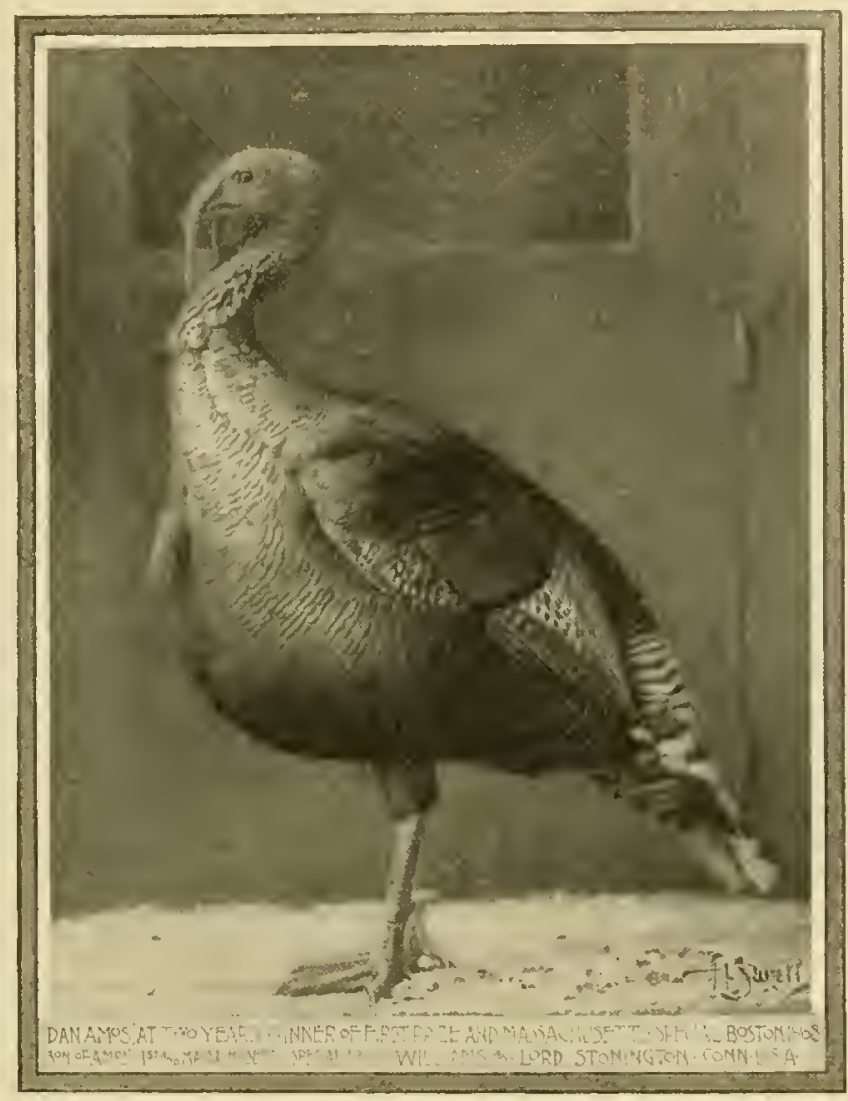

\section{Bronze Turkey Cock}

Mr. F. I. Sewell, the artist who photographed this bird, wrote of it: "Judges and breeders at the Boston show admired Dan Amos not for his unusual weight of forty-six pounds but because his great size was modeled into such a beantiful form and ou acco 1 t t of his majestic carriage and fine
color. Those who are nsed to studying the exceptionally fine turkeys each year at Boston show know that those winnings represent the best in the Hast." times. At any rate, use it as often as required, becanse poults cannot thrive where lice abound.

I slatted coop three feet square and two feet high placed where the grass is short and pulled gently to fresh ground each day serves as a home from two to four weeks. Occasionally a hen will not take kindly to being confined and in her efforts to free herself will injure if not kill her young. We know of no better way than to let her go and rear them as instinct teaches her.
During pleasant weather two feeds a day are vheat, bran and corn chops with a sprinkling of chopped nion tops. cabbage or lettuce, dampened with milk or water. Fine sharp grit is put where they may get it at easure and it is very essential.

Malie an iron-clad rule nerer to overfeed during the first two montlis. If you do, liver trouble will be the result and it will prove fatal to most of those that are affected. Mlout the fifth weel cracked corn. whole whent, luarley or other small grains may be included in their diet to advantage. but the mash described above constitutes the main ration throughout the season, supplemented later by crushed ears of corn scattercd about the rards. Mangels and cabbage malie the best green foods for winter and they are greatly relished.

It may be well to say right here that Indian corn is the chief food on most of the turkey growing farms during the fattening period preceding Thanksgiring and continuing up to the holiclays. The superiority of the lihode Island turkey in our large markets is due to its plump condition and pale colored flesh-results of being fattened on the native white flint corn -and its neat appearance the result of being carefully dry picked. New Jondon County probably furnislues half the so-called Rhode Island turkeys and from one of the many flocks there the choice bird for the president is usually selected.

\section{(ARE OF TURKETS}

Early roosting on perches should be disconraged for the reason that the tender breast bone is liable to become ill shaped and the marliet value reduced.

The best roosts are those that are low and nearly on the level, otherwise there will be continual strife for the higliest perch.

Turkeys are healthier in the open air. On rare occasions one may be blown from the roost during a cold snow storm and perish, but we have yet to learn of any being frozen while clinging to the perch. 


\title{
TURKEYS ON FISHERS ISLAND
}

\author{
Turkey Raising Profitable-They are Not Difficult to Breed Under Proper Conditions-Wide Range Essential- \\ Half-wild Turkeys-Selecting Breeding Stock-Hatching and Raising Poults-Profits
}

\section{E. II. W. FERGUSON}

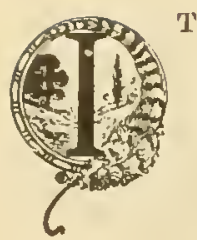

T ALWAIS gives us great pleasure to write anything pertaining to Bronze turkeys, and especially to our turkeys, for our work with with them has been productive of much satisfaction, not to speak of a very consider. able profit.

While we shall make this article chiefly a history of efforts in turkey breeding, rearing and exhibiting and a brief treatise upon our methods, we realize that all turkey raisers have not the same environment and will endeavor to write in such a manner as will be interesting and instruetive to every breeder wherever he may be and by whatever conditions surrounded.

It seems to be an established fact that turkey raising in this country, particularly in the east, is on the decline; where years ago a flock numbering one or two hundred was a profitable adjunct on the majority of country farms, now these birds are found but rarely and then in flocks of a dozen or less, tolerated rather than fostered. The cause is hardly apparent; the thickening settlements have not yet encroached upon the solitude of many a back-lying farm where green pastures and sheltering woodlands offer ready for use, the best possible food and shelter. True, they may damage to some extent the growing crops, but they will render services much more valuable than what they destroy, in the wholesale destruetion of bugs and insects which threaten the farmer on every hand and which they incessantly pursue as the principal article of their diet.

We are sometimes told that turkeys are difficult to raise and lack a strong constitution, but common sense, backed by our actual experience, tells us that such is not the case. In fact if they be allowed to indulge their natural desire for a wide range and outdoor life the year round, and are properly bred, anything but strength and hardiness in their make-up, would seem well-nigh impossible. But where such cases exist it seems to us that the cause must be found in the absence of one or another of these conditions.

We believe that a wide range is rery essential and that although turkeys can be reared and kept in an enclosure of moderate area, a much less percentage will reach the highest development in size, shape or color. With this condition provided and a lack of vigor prevailing an inherent reakness nunst be present in the blood of the parent stock. This may be traceable to indiscriminate inbreeding or unwise mating. In no other domesticated fowl does deterioration so closely follow careless breeding, and for a farmer to breed the same small flock year after year with no further attention than is required to select the largest and fattest for his Thanksgiving dinner, is to invite fajlure by the most expeditious course

Mistakes in adding new blond may prove equally demoralizing; in fact, we can cite cases that have come within our otrn observation where a breeder has sadly depreciated the value of his stock by adding a bird which, apparently strong and healthy in itself. had an inherited wenkness caused by poor breeding. We speak of these matters not to discourage the prospective breeder or the disheartened farmer, but to emphasize the advisabilitv of close adherence to the methods that have proved successful and the ralue of a careful study of the principles involred.

Some years ago we managed to secure at heavy expense a flock of genuine wild turkeys, which, although purchased for the purpose of crossing with our Bronze to make a better foraging market bird, have prored to be of inestimable value for infusing new vigor into rundown flocks, and we sell every year a large number of toms for this purpose. The half-wild make a market fowl par excellence; they are rapid growers, carrying a considerable amount of fine-grained meat, and support themselres almost entirely throughont the year by foraging. When crosser on the pure Bronze as a strengthening agent, reducing the wild blood to one-fourth, the increased stamina is the only apparent effect.

\section{SELECTING BREEDING STOCK}

The selection of breeding stock with us begins as soon as the young turks are given their first food in the fall, say the first of October, when any bird that gives particular evidence of lusty good health and sturdy growth becomes an object of especial interest to be carefully watched as it matures and finally selected for use if it has constantly maintained its robust health; but it is discarded if the slightest evidence of wealness has been detected.

The final selection is marle usually in January when the stock is at its best. We have found that one male to every twelve females is about the right proportion, and we advise that at least two males be allowed to run in the same flock in view of the fact that occasionally a hen will refuse to mate with a certain tom, but can readily agree with another, and also to safeguard against loss should one of the males be, or at any time become, wholly or partially impotent. When one recollects that the female is served by the male only once in a season, the wisdom of this plan is obvious. But care must be taken to use toms that have been accustomed to each other's society and that agree, else it will be necessary to confine one each day while the othcr runs with the hens, changing them every night.

We endeavor to get our breeders in a condition of medium flesh, as a fat bird never gives satisfactory results. For this furpose we consider oats to be the best food, and it is fed exclusively so long as food is required during the breeding season.

When we began with turkeys we did all manner of things supposed to contribute to their welfare, but we have gradually giren up trying to do what they are better able to do themselves, until now we leave them pretty much to their own derices and find the results far more gratifying.

\section{THE TLRKEY AND IIER POLLTS}

Occasionally it happens that two or three hens are found laying in the sauc nest, a proceeding which is nsually discorered by the slightly different color of the eggs. In this erent we remove all eggs as laid, substituting a couple of clina eggs or duck eggs to guard 
against a change of nest. When one hen begins to sit we give her a full quota (fifteen to eighteen eggs) and confine the other heus for a few days, after which they will begin laying again in another nest. If, however, the discovery is made after incubation lias begun, we prefer to let them sit together unless we can ascertain unobserred that there is but one sitting of eggs. And we will here state that we always try to make our visits at a time when the hen is absent, otherwise she may become worried and give up her nest. When the hatch is complete, we provide a little nourishment for the young turks in the form of stale bread moistened in milk; this will assist them to gain strength until they are well on their feet, after which time they get their food from the earth and air. Occasionally we find one weaker than the others, by reason of slowness in hatching, which is unable to leare the nest with its mates; such a one we care for until it is strong. enough to go with the hen. After they are all able to hustle about, we put poults and hen out in the low bush with which the island is plentifully supplied, and pay no further attention to them until well into the autumn, when we begin to get them together for the fall feeding.

As they grow and develop through the late summer and early fall they gradually form into several large flocks, which wander about together under the guidance of the old toms, each flocli having its own roosting place, generally at least a mile from that of any other. In October they are found to be in excellent condition and require but little feeding to fit them for the Thanksgiving market. At this time they are very suspicious of any one who tries to approach them, but soon become reconciled to the presence of the feeder and will surge around him with such force as to endanger his footing. Corn is the only food giren at this season, and as killing time approaches we feed them all they will eat.

The greater part of the market stock is devoted to the Thanksgiving trade and is shipped to private families all over the country; but there is always a certain number that are not fit at that time and which are reserved for the Christmas season. By furnishing each year a very fancy grade we find ready sale for all we have to dispose of for table use at a considerable adrance upon the highest market quotation. These are carefully picked and drawn, the heads, shanks and last joint of wing being remored, and are then packed in clean boxes, in which they are shipped direct to the residence of the consumer.

December usually ushers in the adrance orders for breeding and exhibition birds, in which we always do a large and satisfactory business. Having so large a number to select from (all of which are selected specimens from the hundreds that we raise), we find little difficulty in filling the most exacting order, and it is seldom that we receive a complaint.

Although our business in turkey eggs for hatching was very satisfactory, we decided to discontinue their sale three years ago and have had no cause to regret our decision. We find it far more profitable to set every egg ourselres and sell the stock instead. In shipping the birds we know that the purchaser will get full value for his money, while in selling eggs too much depends upon various conditions.

\section{PREPARING FOR EXHIIBITION}

Our method of preparing turkeys for the show room is simple indeed. It consists wholly in taming the bird and getting it accustomed to being handled. Our turkeys coming from a range of over five thousand acres are as fit as only a free, wild life can make them, full of rich, red blood, which sustains their vigor and spirits tllrough the longest trip and the tedious. weakening confinement of the exhibition hall. They have a hard, smooth and wonderfully brilliant plumage, together with tlat robust derelopment and noble carriage that is never found in a. turkey raised in confinement.

We select the birds that we are going to show about two weeks in adrance of the time when they are to be exhibited, and always take up more than we expect to show to insure laving our full cntry in case one or more

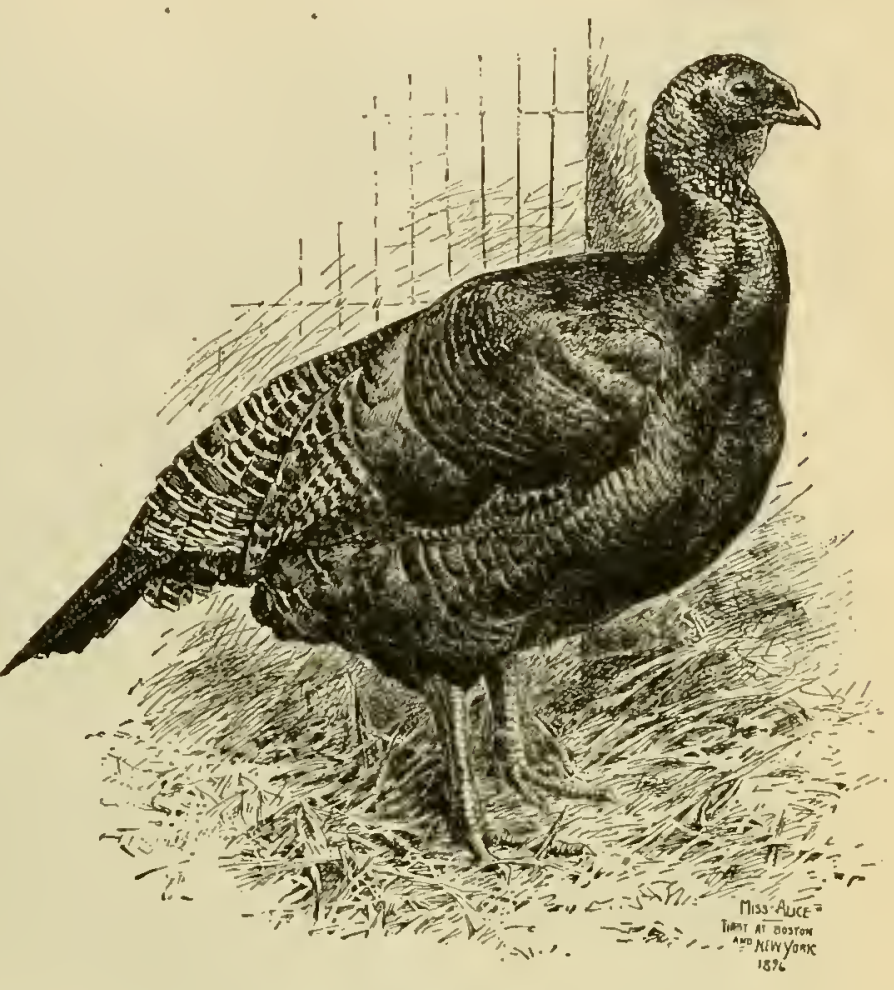

"Misa Alico"

A Bronze Turkey Hen, that traveled two thousand miles to shows and nere. was defeated. Owned by E. M. \& W. Ferguson.

of the birds becomes damaged in plumage or otherwise. These are handled with the utmost care, as it is very easy for a struggling bird to break a number of wing flights or to strip feathers from its thigh, where a careless handler is almost sure to get his grip.

\section{PROFTTS}

To any one who has read the foregoing paragraphs it must be evident that turkey raising as it is managed here -aud we know of no reason why our methods and success can not be duplicated in almost any locality-is much more profitable than any other farm crop that the farm can produce. Any one who is apt at figures can easily figure out the possible profit to be derired in his own locality, which will be gorerned by the cost of food, the area of the range available, and the price that can be obtained for the product.

We would say in concluding that as many questions will doubtless arise in the minct of the reader which have not been clearly answered in this article, we shall be glad to see them at our farm. where we shall always be pleased to explain every detail of the business and where we can give far better instruction verbally with the birds and their home to illustrate our worrs. 


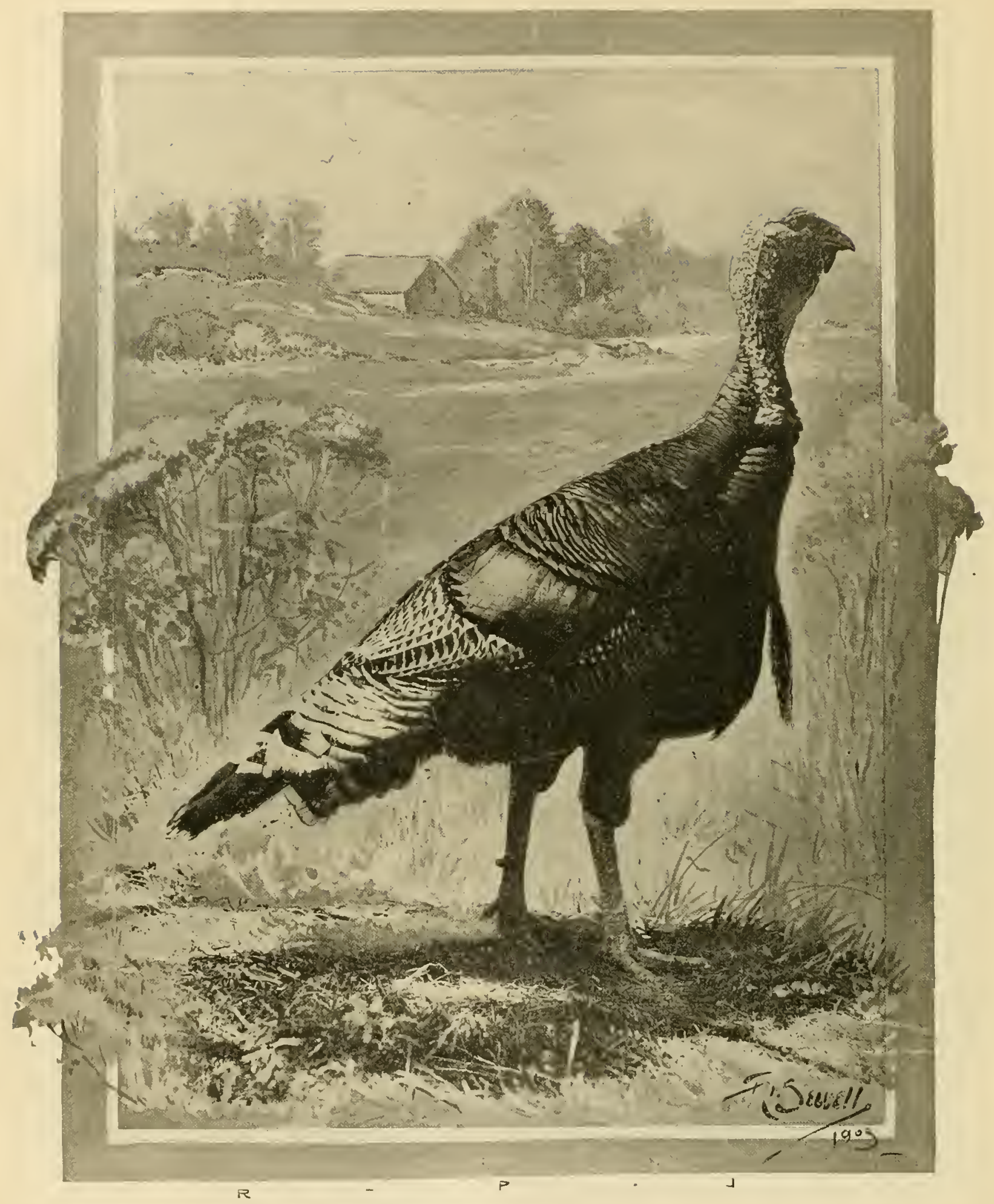

A Typical Forty-Pound Bronze Turkey Cock

The above splendid specimen of Bronze 'Turkey was Second Gobler at Madison Square Garden, New York Sbow, exhihited by Mr. George W. Salsbury. Forty-pound Bronze males are not rare at the leading shows; however niales that are so much ahove standard waight rarely possess such rounded form in all sections. "The great fault in most large poultry is coarseness, the mediun-sized birds of the breed as a rule being nearest the ideal form. We present the atove as one of the most symmetrical males shown above 40 pounds. and where show quality is sought.-F. L. SEWELL. 


\section{CARE AND MANAGEMENT OF TURKEYS}

Raising Bronze Turkeys in Canada-Best Soil for Turkeys-Inbreeding and Line Breeding-Shape, Color, MarkingsRoosting Houses Used with Success-Young Hens as Breeders-Setting the Hen-Care of

the Young-Diseases-Catching and Weighing-Selling Stock

W. J. BFLL

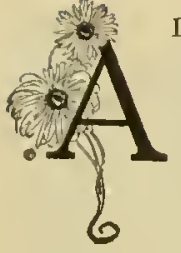

LTHOLGH I am aware that turkeys are raised successfully on all kinds of soils and in nearly all locations, I believe that sandy land or clay with an abundance of gravel is a better place than heary clay soil, espe cially if the latter is not well drained. On two of my turkey farms the soil is grarelly: clay and there is running water all days of the year and from those farms have come my largest turlieys.

When I nored to my present farm in 1893 , which has no sand or gravel in its composition. I noticed the poults a day or two after they were moved out on the ground from the nest commenced to look sickly. I could not imagine what was the matter, as they were free from lice and their treatment was the same as previously given on the home farm. Ju watching them going around I noticerl they were pirking it small substances. I immediately procured some fine aravel for them, and an improvement was notice"able in about a day's time. This shows what is gained by close obserration and also that the dying of poults is caused-not by the food given, which is usually the cause assigned -but through overlooking what may seem unimportant matters. I consider a fifty-acre range necessary for even a small flock.

\section{BREEDING SHOH STOCK}

Some writers say that to mate Bronze turkeys you have only to "discard all specimens disqualified by the Standard." After thirteen years spent in breeding these birds I must say I disagree with them, for I have found the selection of the largest specimens and inbreeding the w to certain extent will increase the size instead of decreasing it, but when carried too far inbreeding will impair the vitality and produce deformities. Therefore, to pioperly mate these birds is, I claim, as much of a problem as mating any of the Standard breeds of fowl. I wish the reader to remember that $I$ am referring to the production of Bronze turkeys for breeding and show purposes.
In regard to the slape of the male $I$ like one that stands well up. By lhis I nean one that, carries his breast high, the same to be moderately full and well rounded. I have $\lrcorner \circ$ use for the bird that carries his breast and body in a straight line parallel with the ground. Fig. 1 is my idea of a good shaped bird, either for the breeding yard or show room, except that the feathers on the rear part of the back were raised a little when the photograph was taken. Select a bird with good. heavy bones, and see that the toes are straight.

\section{COl.O1:}

When you examine the different birds in the show room you will find on breast and neck almost as many shades as birds. There is the green bronze, the black bronze, a dulı brown bronze and a yellow bronze. The latter is $\mathrm{my}$ preference, and what I think is called for in the Standard, although plenty of judges favor the black bronze color. The body and back will be darker, with bronze reflections. The legs sliould be pink.

In the wings and tail are where the faults appear. Spread the wing and look for solid black feathers in the primaries, irregular harring in both primaries and secondaries and also a white edge along the bottom of each feather in the latter. They are barl faults. Fig. 2 is a good wing. The tail, which includes tail corerts, is seldom perfect; in fact, I hare nerer seen one. The black bars near the end of the tail corerts (I mean the row of feathers lying $f$ a $r$ thest out of the tail proper) are generally missing, and two center

feathers of the tail proper
Feathers on rear of hack were shightly raised by the bird's excitement at having his picture taken. always have the white tip, the black bar and the brown barring more or less mixed. I have noticed the latter peculiarity in the wild partridge. Spread the tail coverts apart and look at the bottom of the tail proper and in a great many cases you will find white barring the same as on the wing. This is another serious fault. Some breeders are satisfied with a tail which is all speckled with black'and brown so long as it has the black band near the tip and a white tip. Now I am satisfied that 
a featler regularly barred with brown and black, with the broad black band and dull white or gray tip, is the proper color. Fig. 3 is as good in color of tail as I have seen.

I cio not refer to all the shape or color sections, but only to those which are usually faulty or in rlispute. The abore will give yum my idea of a good male to head a pen, except on one point, and that one in my estimation is the most important, viz., you slonld insist on having a Iine-bred bird. If you use a bird produced from two strains entirely different in build and in a great many sections in color as well, what can you expect? My advice is to have a good male sired by good males of one liue of breeding.

What I liave said in regard to shape of male will apply to the females also. The Standard says of the female. "'The entire plumage is similar to that of the male, but the colors are not so irilliant or clearly defined, and the edging of the feathers dull white or gray." Now some brecders say that hens sliould liave a gray edge to breast and back featiers, and I must admit that the great majority of hens are marlied that way; still the meaning I take from the "colur of the female" section in the Standard is that they should have the same color as the male, and I claim that the females in all our shows are scored too high. It is not impossible to produce them, for I have produced quite a few and find a great demand for them.

Young hens in my experience have proved the most satisfactory breeders. The old hens in a great many cases (and young hens sometimes) will lay soft shelled and misformed eggs in spite of all I can do. I have starred them; have had an abunlance of old mortar and lime before them; have given them free range and every. thing I could think of, but I cannot stop them entirely. I consider it the only fault the Bronze turkeys have. Usunily I mate seven or eight hens with one male, but I think more than that number would still give satisfactory results. Any shed or building not too warm will do for a

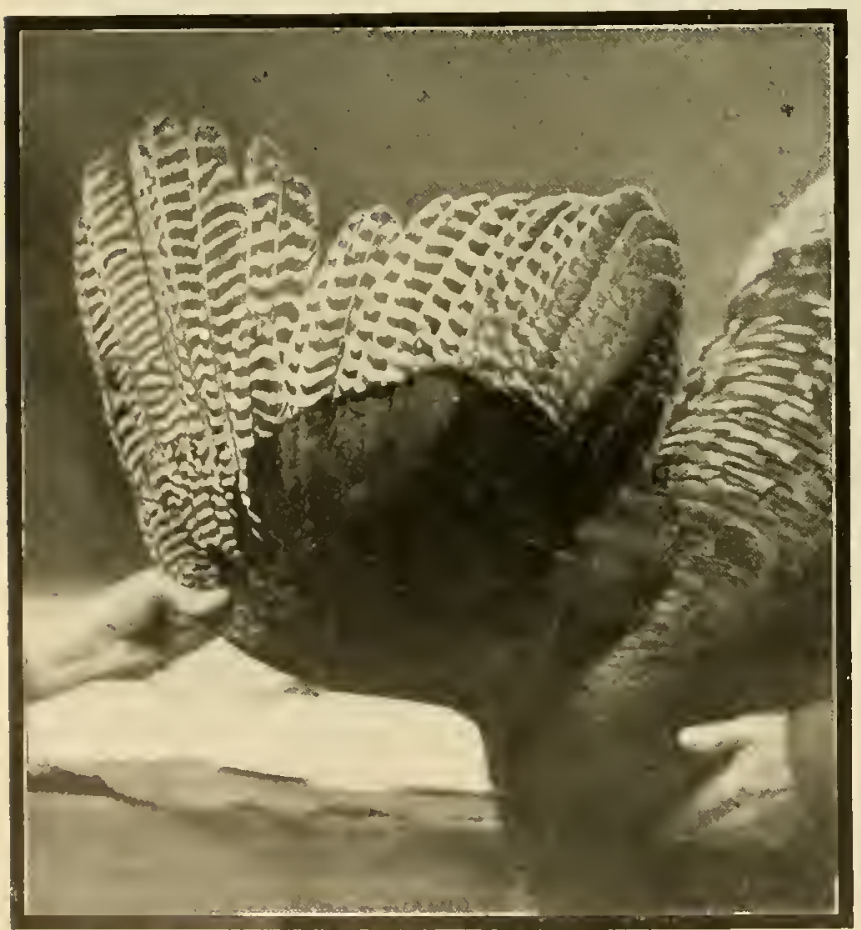

Fig. 2-A. Ten years ago this was considered an exceptionally goud wing roosting place for breeding stock. 'l'hey' should be given free range during the daytime in all weather. I woulk advise feeding the male pretty well, but the liens only lightly.

\section{SETTLEG THE IIEN}

At this stage it is a good plan to have nests prepared, as I have noticed hens looking up nests a month in adrance of laying. Have them roomy. so the hen can turn and come off withont brealing the eggs, and place them

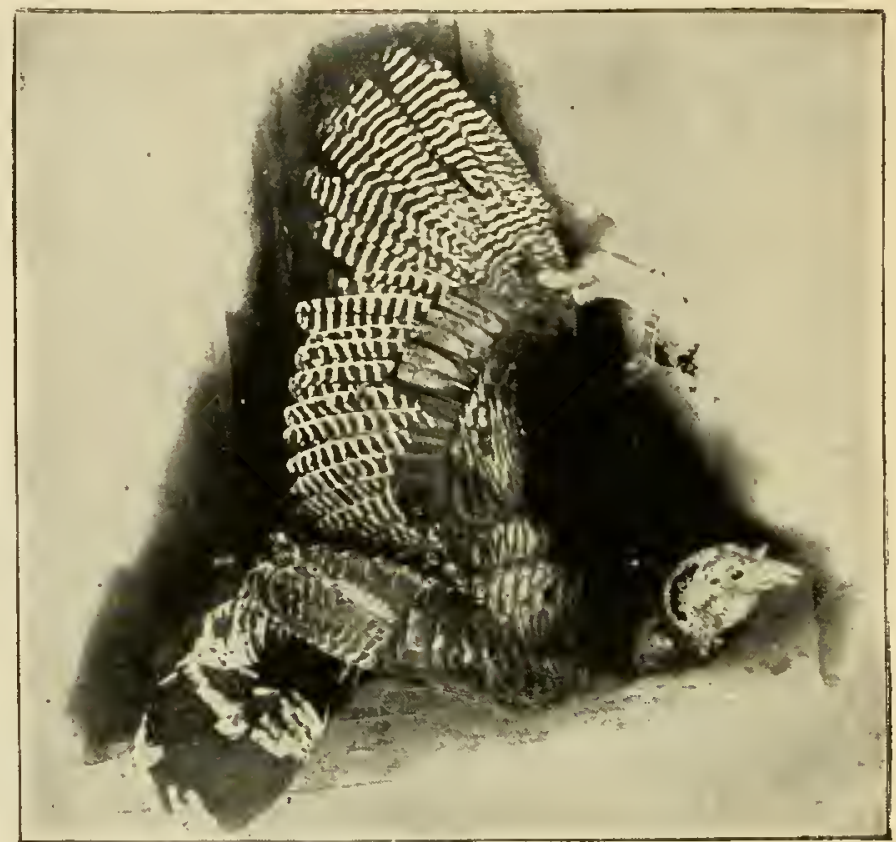

Fig. 2-B. The wing of a present day Bronze Turkey. Shows the improvement in markings made in the past decade. Bred and Owned by Mr. W. J. Bell.

in all the corners and secluded places that you can find. By doing this early I save myself the trouble to a great extent of hunting the turkey nests. It is a good plan to watch which hen lays in a certain nest, and mark the eggs as you gather them, placing them in bran in a cool room until the turkey wants to sit. Then dust the nest weII with insect powder and give them to her-about serenteen eggs if she lays that many. Some advocate piacing the first laying under domestic hens and forcing the turliey to Jay a second lot, but here in northerm Ontario the late July hatches are seldom a success. About two days before the eggs are due to hatch dust the hen and uest well with insect powder. I consider this one of the most important things to do, as a young turkey cannot stand a dose of lice the first thing.

\section{CARE OF TIIF YOUNG}

When you bring the young from the nest mark them on the web of the foot with a small poultry punch. If markerl when about tiventy-four hours old they seidom bleed and the lole never grows together. By doing this and keeping the hens' eggs separate you can ascertain which hen is producing the best birds. I now come to a period in which my treatment of turkeys radically differs from other successful breeders, but I have had very few casualties under this system and so I intend to continue following it, and, further, I can laise them by this system just as easily as clickens. About twelre hours after the last poult is hatched I take them to a larger boxturkey and all. I feed them bread soaked in milk. 'They 
will not eat mueh at first, but by sticking a little of it around the sides of the box and working it on your hand among them, they get started. I keep them in this box from one to two days, depending on the weather, and get them taught to eat off $\mathrm{my}$ hand. Then I change them to an $\Lambda$-shaped coop with no bottom, and a lath front, and gradually I substitute shorts for the bread in their food.

I feed them their shorts entirely out of my hands until they are sold. I am very often told by my customers that they are surprised at the tameness of $\mathrm{my}$ turkeys. Another advantage gained by feeling out of your hand is that there is no food left on the ground to sour-a fruitful source of bowel trouble.

Up till fire weeks of age I feed five times per day and cut dandelion leares fine and mix with the shorts nearly every meal. I occasionally cut onion tops instead of the dandelions. Give plenty of milk-any kind-to drink, and keep fresh water before them all the time. Something which should never be negleeted is to more the coop the breadth of itself every clay. In mixing the shorts it is important to have them quite damp, but not sticky. There is one fine grade of shorts it is impossible to mix properly. I am aware some claim that feeding fire times per day will kill the poults, but they surely have not tried feeding shorts and mill. Shorts digest very fast and I believe is a preventive of bowel trouble. At any rate I hare found it a very slow-lijling process.

At about five weeks old I give the hen her liberty and let them lave free runge of the farm and roost on the fences or buildings until fall. I only feed twice per day during the summer-shorts mixed with inilk in the morning and clean wheat at night. If grasshoppers are plentifui they will oft-tines refuse the wheat. but with me they nerer refuse the shorts.

\section{HOLSING}

When I first started 1 found great difficulty in gretting them to roost in a shed at night during winter. I wonld spend over an hour leeping then from goung on the

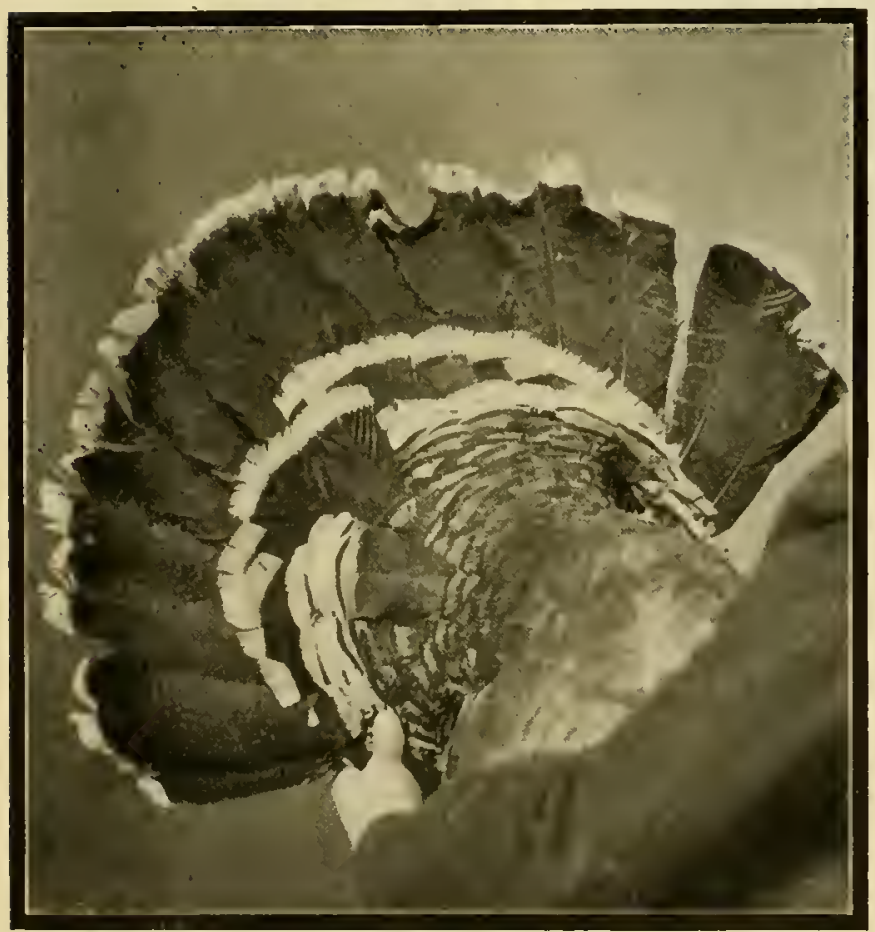

Fig. 3-A. A tail considered fair ten years ago. Bred and Owued by Mr. W. J. Bell. fences and buildings, so I thought of a plan which has worked satisfactorily erer since. I built a lear-to on the south side of my farm barn. Twelrc feet irom the barn and parallel thereto four posts were placed twelve feet apart and seren feet abore ground. On these were placed a four by four-ineh scantling. Then to the side of the

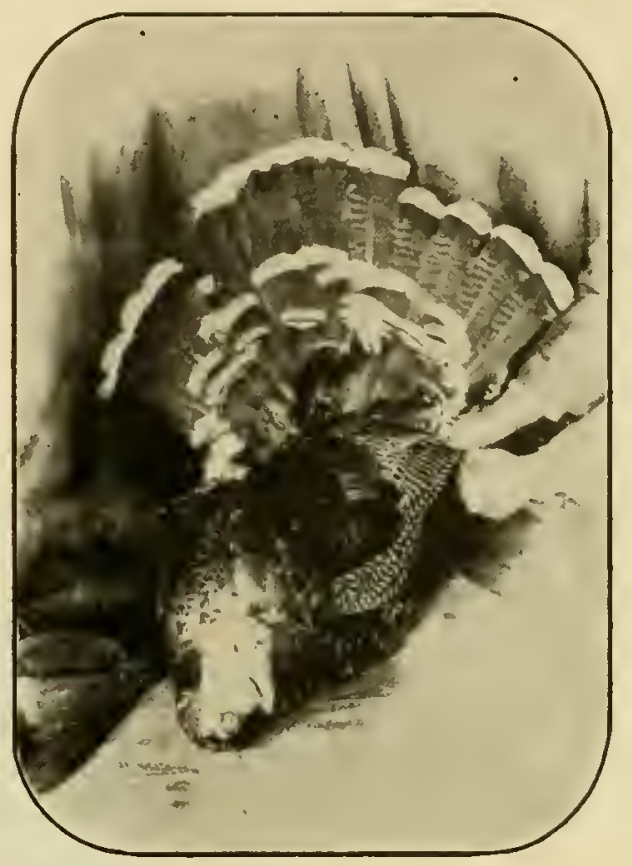

Fig. 3-B. A Mudern Hronze Turkey Tail, This tail shows the improvement made in standard marking during the past ten years. Bred and
Owned by $M r$. W. J. Bell."

barn, twelve feet from the ground, another scantling was spiked, and on these were placed the rafters. The two ends were then boarded up elose and also the front, except what was required for doors and windows.

Now the rafters were not cut close to the building, but extended orer about four feet. Straight under the points of rafters I placed four short posts twelve feet apart and two feet above gromul and boarded this two feet up solic. From these boards to the point of rafters was strung poultry netting. One and a half feet from the ground and against the two-foot boarding was nailed a $V$-shaped trough the entire length, thirty-six feet, and a door placed on the end of this "run." The inside or house proper can be divided into two or three compartments as required, with roosts, and a large slicling door and a window for each compartment. I advoeate placing the roosts on a level and about four feet from the ground. All I have to do now is to place food in the trough, drive the turkeys into the "run," leave the sliding doors open and they have plenty of light to sce their food and are compelled to roost inside. Then, again, if the weather is warm the windows ean be raised and the sliding doors leit open all night, and if cold all can be elosed. Figs. 4 and 5 will give an idea of this building. Of course the rafters are boarded orer and shingled.

\section{DISEASES}

I shall touch very lightly on this part of the subjeet. I have had rery few turlieys die from disease. It one time I housed them in a building much too small, and they contracted roup. I tried doctoring, but found it was not a success, and now use all $m y$ energies in prerenting disease. 1 firmly believe if you let your birds have free range in daytime, feed at regular intervals and 
keep them free from lice you will have no more trouble tlisn in raising any other line of live stock. My greatest troulbles have been soft shelled eggs and foxes.

\section{CATCHING AND WEHGHIN:}

While our Provincial show was judged by score card and all birds were weighed, I was generally asked by competitors to catch their turlkeys and place them on the scales, as [ could handle the birds more easily than any other. In eatehing a turkey, if on the ground, I stand on left side, place my right arm over its back and grab both legs. Lift by placing left hand under the brcast. It may try to break loose for a second or two, lut hold steady, and it will give up. If the bird is on a perch, grab by both legs from behind-right hand for right leg and left liand for left leg-and draw quickly from the perch so its breast or wings will not strike it; then hold steadily while it flaps, afterwards it will remain quiet if held by the legs. In placing on the scales hold its feet toward you with the right hand and breast. with the left. Lay it on its right side and pull its riglnt wing down towards its breast as much as possible when withdrawing your left hand. Nake your movements gradual and quiet and you will have rery little trouble. It is almost impossible to get their weight while standing on their feet. In weighing as abore if small counter scales are used it is adrisable to place a box of the same size as the scales and about one foot

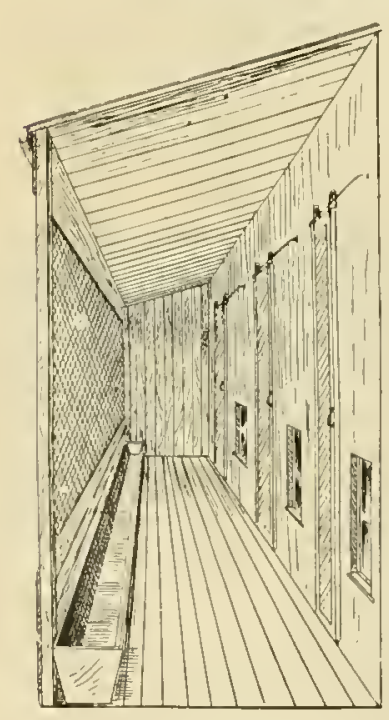

Fis. 5.

Runway in Turkey House. Showing Feeding 'Trough and Wire Netting. higher under the scales, as the head and tail of the turleys will droop a little on each side and having the box nnder the scales prevents them touching the flool.

\section{SELLING STOCK}

It would require a whole book to treat this subject properly, as it includes advertising and making coops. I think the best advice I cam give is to be perfectly honest and truthful. I have found more persons lie about the weights of their turkeys than about any other one thing in this world. I have bought turkeys at different times to be a certain weight and in almost every case have found them five to ten pounds short. I am aware that turkeys will lose about two pounds in transit, no matter how short the distance, but seldom nore. Then again yon will notice prominent breelers using euts that hase been in existence for vears, as if said cuts were from photographs of their stock. A case of this kind which amused me and caused me not to trust a leading breeder with my order was to find a cut on his envelope and underneath laheled "S-3rd, 1st prize cockerel at C- - 1899," and right in front of the cut in small type was "F. L. Sewell, 1597," which showed that the cnt was made before the bird it was supposed to represent was hatched. 


\title{
HATCHING AND REARING BRONZE TURKEYS
}

\author{
A Successful Breeder of Mammoth Bronze Turkeys Gives Valuable Acivice for the Beginner with Turkeys-Importance \\ of Properly Conditioned Breeding Stock-Management of Layers and Care of Eggs-Housing, Feeding and Rearing
}

\section{RAIPII S. MOSELY}

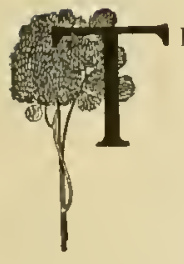

IIIS article being composed particularly for the benefit of the beginner, or amateur. who is starting in or who las 1 ronlule in raising turkeys, I will try to write sn anyone can understand how I have raiserl llammoth Bronzc 'I'urkeys, year after year, and what I have found the most jractical way to latch and rear them.

How often one liears people say that turkeys are hard to hatch and raise. It is a settled fact that turkeys cannot be raised under the same conditions as most chickens are, as we know that the turkey is not domesticated the same as a chicken, but we do know that if turkeys are given range and a place to thrive, with good, sensible care, they become as easy to raise as chickens.

Before saying anything about the hatching of eggs, let us consider the breeding stock that produces the eggs. The question arises, "Are you sure your stock is in the best condition to breed from?" The best condition means that they shonld be well matured, vigorous and free from diseases. As the breeders are the foundation of your flock of young turkeys, this coming year, you should note carefully this important point, as those who breed from the late hatched, or scrubs, are as a rule, the ones to complain that turkeys are hard to raise.

FERTILITY OF EGGS

Some a mateurs say "My turkey egg's don't hateh well. What is the trouble? I feed them all they want to eat and give them the best of care." There are quite a few reasons for eggs being infertile; some, on account of the turkeys not being healthy, others, because the stock is confined in too small a yard, but the principal reason is because the turkeys are too fat, not having been reduced in flesh during the winter after they were selected from the flock that was fattened for marliet.

\section{MANAGEMENT OF LAYERS AND CARL OF TIE EGR}

My breeders are fed oats and Canadian peas, once a day, during the winter and spring, and about a month before I think they will lay, I begin to feed some ground bone, once or twice a week.

The ground bone tends to make them lay earlier, and makes the eggrs more fertile, especially if there is no green food to be obtained in the fields.

About two weeks before they commence to lay, 1 place some salt barrels on their sides, along rail fences near hrush heaps, a little way from the house, and put some stinw and leaves in each, with a nest egg. By making nests in this manner, I have no truuble in keeping the turkeys from running to the other end of the farm, therely losing a part of the eggs.

I gather the eggs every day, marking upon each egg the date and name of hen laying same. Py doing this, 1 know how ofl each egg is, and can keep the pedigree of each turkey when hatched. As quickly as the eggs are seculerl, they are put in a room where the temperature ranges from 50 to 60 degrees and turned once in one or two days, until I want them to set.

\section{SETTLNA AND UATCHING}

Those who have observed carefully, know that generally when the first turkey commences to sit, the last one of the flock begins to lay, and to lieep the first turkeys laying. I break them up and make them lay a second litter.

When the turkeys are half through laying (about twenty days from the time the first egg is laid) I gather all the eggs laid up to that time and set them under chicken hens, giving eight or nine to each hen, according to her disposition and size. The nest is made one foot high and fifteen inches square on the sides. In one side there is an opening for the hen to enter. A frame of muslin is hinged on the top for a corer, rentilation and convenience.

The nest material is a sod about fourteen inches square and two or three inches thick, and to make the nest concare, the bottom of the sod is scraped a little in the middle, then a thin layer of straw is placed on top. The sod makes the best nest, as it gives the eggs the right amount of moisture, to give the best results. Is previously stated, I set my turkey eggs under hens, so I can get more eggs from the turkeys, and because there will be no disturbance from foxes, sliunks, ete. Two or three times the sitting hens are dusted with insect powder until I an sure there are no lice left to disturb the poults. Enough gentle sitting turkey hens are kept in reserve to take care of the poults when hatched.

When the eggs are about to hatch (about twentyseven days) I give a few of them to each turkey to hatch, so that she will own the young poults. I have had iurkeys. that, after sitting only three days, became the best of mothers. I leare the poults in the nest, fixing 
the opening so they cannot drop out and get ehilled. At the expiration of forty-eight or fifty hours, I look the poults over carefully and if I find any of them with the yolk sack not absorbed and digested, I leave them in the nest, taking out the rest and giving twenty poults to each turkey in their respective coops or houses.

\section{HOLSES, FEED, KEARING, ETC.}

There are two ways of rearing turkeys, one by putting the joung turks out with their mothers at the other end of the farm and letting then shift for themselves until fall, while another (and better for me) is partial confinement when young, giving them free range when older; feeding once or twice a day to induce them to come home. The latter way produces larger boned turkeys, and insures more freedoun from foxes, ete.

Iy turkey houses for the young poults are 10 by 20 feet, divicled by partitions into three apartments. The sonth end of the louse has four windows, and the east side two. The four windows in the south are kept open except when it storms they are eovered by muslin curtains. When forty-eight hours old I give the first feed of fine chick grit, eharcoal and water. The grit gives the poults teeth for the next feed and starts the maehinery going; seeond feeding is stale bread soaked in sweet mills squeezed dry, part of a hard boiled egg and enough powdered charcoal to give the food a darkish color, Feed this every two or three hours for three days. Once a day feecling green food, such as onion tops, lettuce or dandelion leaves, chopped; grit and fresh water is kept constantly before them. It is very important that they do not bave all they will eat at eaeh meal, as their systems eannot stand the strain of continual gorging-it causes liver trouble or diarrhoea, when about four to six weelis old. When three days old I let the hens and poults out in the middle of the day, if pleasant; after a week they are able to stay out all day, and they are then fed three times a day on bread, eggs and charcoal, nntil two weeks of age, when the eg'g is left out and wheat fed at night until three weeks of age. After this they are gradually worked on to johnny cake and eurds in the morning and wheat at night. The johnny eake is composed of two parts white uniddlings, one part corn meal, one part ground oats, a little pure beef seraps, mixed with skim or sweet milk, and baked until thoroughly done. When fed take as much eake as will be required at one feeding, mixing with one-third milk eurds giving them only what they will eat up quielsy. I continue this feed for one mouth, after that feed oats, peas and skin milk to give growth. By this method of feeding have raised young toms that would weigh $371 / 2$ pounds at eight months of age being just in ordinary breeding condition.

\section{LICE}

Young poults should be looked after very often and see that iice are destroyed with good insect powder. Look sharp for they are hard to see. Lice will kill a poult in a very slort time.

\section{INDIGESTION OR WIITE DIARTIIOEA}

It is generally eaused by over-feeding, letting them out when the grass is wet, thereby getting chilled, filthy drinking water, or irregular feeding. I have found powdered eharcoal, mixed in with the feed an excellent remedy for this, at the same time keeping them dry. Sweet milk sealded in whieh a little nutmeg is grated is also a grood remedy.
SUMMART OF SUCCESSEUL TLRKEY RAISING
1. Breed only from vigorous, well matured stoek.
2. lieep stock in healthy condition.
3. Do not let poults rum in wet grass.
4. Do not over-feed or starve young poults.
5. Make war on the lice.
6. Prevent disease by disinfection.
7. Use your best judgment and common sense.
8. Give plenty of range. The turkey is naturally a wild bird and will not thrive in confinement.

\section{SOME PRACTICAL HINTS}

\section{O. E. SKINNER}

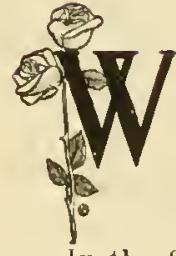

HILE I have not had as much experience in raising turkeys as a good many others, I hare liad continued experience with them for orer thirty years, but my remarks on the turliey will be from a practical standpoint and I slabll leave the faneier's portion to some expert judge.

In the first place, everybody knows that turlkey eggs, as a rule, hatch well, but the rock that wreeks all hopes is the art of raising them after they are hatched. One of the most successful turliey raisers I ever knew handled lier young turkeys about as follows: She never let them out while there was the least partiele of danger of getting their plumage damp, even if she had to eonfine them a. whole day. I was there once after a heavy rain and she hat then elosely confined in a small box. I made the remark. "You will surely kill every one of them eonfining then in such a place." But upon visiting her a few months later slie still had every turkey that had hatched. I believe this is the great seeret in turkey raising-keep them absolntely dry and free from lice and nature will do tlie rest.
Another neiglibor who is just abont as sucessful handles his the same way, only he uses turkey hens for mothers. He follows the same plan about keeping them from getting their plumage damp when young. He has domestic hens sitting on the eggs, but he lieeps giving them at night to the turkey hens until they have some twenty-firc or thirty each.

\section{WELA SILAPED MIRDS COMMAND A PREMIITI}

'The ery nowadays is for as large turkeys as possible. This is all right provided you retain the full breast and good shape generally. If you will obserse the daily market reports, you will notice that the quotations say that serawny turkeys (poor shape) are either not wanted or will be taken only at a big diseount. So after al] it is the shape that sells the turkey rather than the overgrown size. I liave always made it a point to breed for full hreast and good shape more than for oversize.

As to feed, I do not believe it euts much figure if the other sanitary conditions, noted abore, are elosely followed. Plenty of sluarp grit I believe necessary for best results, however. 


\title{
POINTS ON TURKEY BREEDING
}

\author{
Loss of Vitality in Turkeys and Lack of . Fertility in Eggs-Injured Females-Food for the Young-Danger from Lice-Their Causes- \\ Care of the Layers and Sitters-Indigestion and Diarrhoea-Preparation for Masket-The Poults- \\ Feeding the Breeding Stock-Advantages of Roosting Outside
}

\section{J. I. CRA NGLE}

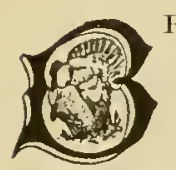

RONZE turkeys are more raised than any other variety, for sereral reasons. First, they are the largest; second, they are hardy and well adapted to this climate; third, they are good laycrs and the best of mothers; fourth, they are most satisfactory for marketing, being full-breasted and possessing the desired color of flesh. They will lay eighteen to forty eggs a season under proper care.

Generally it is considered that one male will mate with six to ten females. I have used one male for twentyfive hens, but I do not think it well to risk using only one male with your entire flock (especially if you have more than eight or ten females) for the following reason: A female nsually allows the male to tread once. If from any cause the male did not effect proper connection, the eggs wonld not be fertile and the best part of the season would be lost because the first litter is considered the best.

The hen after connection selects a spot for her nest and a few days after it is made. This is usually done by scratching up the earth so as to make a hollow place to keep the eggs from rolling out. A great deal of the risk of males not fertilizing the eggs could be avoided in the following way: Use two toms alternately every day, but under no consideration allow both toms to run with the females at the same time. Ir you do you will, as a rule, have bad luck, as the males will fight and at times hurt themselves, also the females.

The lack of fertility in eggs and vigor in young poults is one of the main reasons for the decline in turkey breeding in the eastern states, and perhaps all over the United States. In many of the eastern states, where a few years ago hundreds of tons of turkeys were raised, they now have to import mostly from western states, to meet the demand, as it seems almost impossible to raise them. I think the main canse is in-breeding. 'There are many farmers who in the past have not thought it necessary to obtain new blood, and who thought they could save a few dollars by borrowing a tom from a neighbor, jn this way using the same blood year after year. This has been done for so many years that the vitality has been about bred out. For the past few years turkey breeders no doubt have seen their folly, because many of them are now looking months ahead for a good male. The vitality had gotten so low that it ereated disease, and I am sure that many of the turkey diseases with which we have to contend have been caused by lowering the vitality of the turkey. I believe there is no other variety of birds in which the rital forces decrease so rapidly by in-breeding as in the turkey.

I think it possible under proper management to raise turkeys in every state in the Lnion, and I beliere if farmers in general will be more careful about in-breeding and will see that they have the proper kind of males to breed from, snch as will introduce new, strong, hardy blood into their stock, they will be able to raise turkeys as they have in years gone by. To people who are having tronble in raising turkeys I advise using a half wild male if they have large range. It is almost impossible to get a pure wild ton in this country, although you may hap- pen to run on one by accident. About all the people who claim to have wild turkeys have nothing but half-breeds, yet with a half wild tom you can get enough new blood to make the offspring very much stronger, and this will be noticeable the first season.

\section{THE LAXING AND HATCHING SEASON}

After the turkey commences to lay, in many sections of the conntry, the nights are cold and in many places the thermometer goes down to the freezing point. When hens are laying and you are afraid of frost, the eggs should be gathered every evening and marked with the date. Then they should be placed in a pan or basket in common wheat bran with the big end of the eggs down, as by so doing you will keep the air cell in good condition. Put them in a cellar or any cool place and turn them every day. It is not best to turn them completely over; turn them only part way orer each day. It is safe to keep them ten or twelve days, but I would not advise keeping them any longer than possible, as they are liable to get stale, in which case not so many of them would hatch. When the eggs are removed from the nest a glass egg should always be put in. If you do not put glass or wooden eggs in the nest the hen will probably leave her nest and lay elsewhere.

A good mother will cover her eggs when she leaves her nest; usually this is done with dry grass or leaves, so that in looking for a turkey nest it is always necessary to be careful, as otherwise one might step on it. An ordinary hen will cover eighteen eggs. If she lays more than that number, take the extra ones and put them under a common hen, setting this hen and the turkey at the same time. If you have a good hatch and get out more than eighteen, leave a few of the poults with the common hen. The turkey hen can brood eighteen poults with safety. Above all things, see that there are no lice on the hen when she hatches, as the poults are very tender when hatched and if the hen has lice the poults will have them on their hodies within a few hours. When you transfer poults from common hens to turkey hens dust them well with a good powder, as you want to be sure there are no lice on them.

It takes twenty-eight to twenty-nine days to hatch turkey eggs. If the turkey does not leave her nest at that time do not disturb her for at least twenty-four hours, because oftentimes a few of the eggs are slow in hatching and she stays on the nest several hours after they are hatched for the poults to gain strength. It is always well to take a piece of stale bread moistened with milk and put it near the nest, near enough for the turkey hen to reach it. If the poults are hungry, they will also eat. This food is rery important because if the hen is hungry she may leave her nest before she should, looking for food. We must remember she leaves her nest only three or four times in twenty-eight days. If she does not appear inclined to move to get the food, do not disturb her, as it is a very easy matter to find out whether she has hatched any young, for as a rule, broken egg shells will be seen near the nest. At the expiration of thirty days, if you see no signs of the young turkeys, it will be well to-investigate the matter $\mathrm{by}$ raising the turkey off 
the llest and ascertaining whether the egg's a re fertile or not, If they should prove to be infertile, shnt up the female for fon or five days in a coop large enough for lier to gret a little exercise. Give her food and water and a place to dust herself and in three or four weeks she will lay again.

One of the best places in which to let the hen turkey run with poults is a field where the grass is short. Is a rule, a pasture is very good; woodland is also suitable. lieep them out of long grass and grain fields when there is a heary dew or it is rainy, until after the grain and hay are harested, because the wet regetation is bad for the young poults. It chills aud sets them back in their growth and often is fatal. Fon will always find the largest and finest turkeys where they have free range. Is a rule, turkeys will wander some distance from home duling the day, but will come back to their lome every night. Under proper management you can place turkeys anymere you wish on the farm, and by teaching them to roost in one particular platce, they will come to regard this as their home, and will know no other; you will always find them wherever they have been taught to roost. This can be done by watehing them a few nights in succession and driving them to the place where you wish shell, it will be porous, 1 have known many germs to die on this aecount.

\section{DISEASEN AND INJURED STOCK}

Lnder no consideration breed from a diseased turkey. It is much safer to lill a sick turkey than to let her among your flock of healthy bircls.

When the males mate with the females and they are extra heavy and clumsy, it is well to see that the male does not tear the female ol hurt her back. I rery good way to prevent this is to file down the toe nails of the male. I have seen them many tnmes slip off of the female and rip open the hips or sicle. It is very easy to discover an injured female by lier actions, more especially the next day, as she will be lame and her wings will droop. It is best to catch her at once and examine the wound, as generally they can be saved by sewing up the tear. This is not a rery difficult matter. Let one person hold the turkey and another do the sewing. Full all the feathers from the edges of the wound, and with warm water moisten them so they will stay back while you are putting in the slitebes. Fefore sewing, the round should be washed thoroughly with castile soap, using a small, suft sponge; then talie a long, fine needle and with white

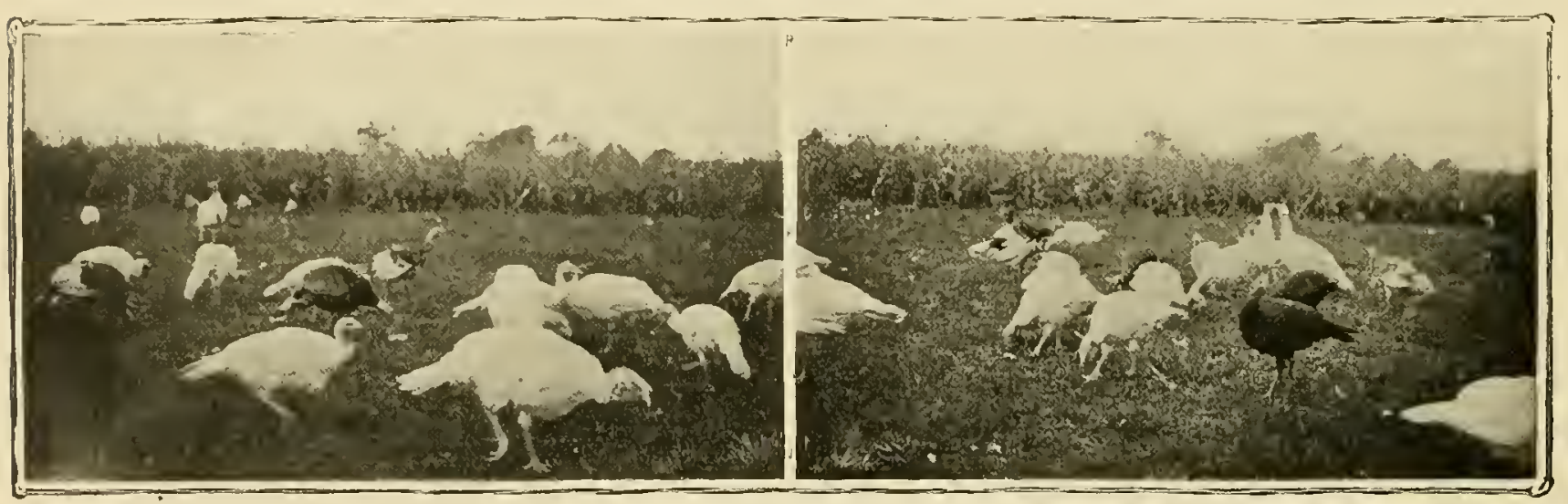

A Mixed Flock

them to stay. Just before dark they will gro up in the trees or on a roost that has been put up, for them. With the right kind of breeding stock turkeys at Thanksgiving time should weigh about as follows: Toms, sixteen to twenty pounds; hens, twelve to fourteen pounds, 1 hare dressed at six months old, turkeys weighing twenty-four pounds, but they are rare.

\section{FEEDINA THE IBREEDING STOCK}

There are two things which have to be done in order to have success in breeding. One of them is to get the right kind of breeding stock, and the other is to feed them properyy. These are the two main things. The proper way to feed breeding stock is to be careful not to overfeed them. After your breeders are selected, feed almost entirely on oats (scalded). I find they do better on wilts than on ay other food. For a change, feed whole corn alout twice per week, and at no time feed more than they will eat clean. Where turkeys have a barnyard to scratch in, you will have to be eareful not to get them orer-tat, and as a rule, it is only necessary to feed them at night. 1 good accompaniment to the food for 1urkeys is eharcoal ground coarse. Put it in a box where they can find it. They also need shells-oyster shells are the best. On a farm they can ordinarily find all the grit that is necessary for them to have. If the hen tnrkey has not puongh lime to properly supply the ego silk thread draw the edges of the skin aromul the wound so that the parts meet as they were. Commence at one end of the wound and gradually draw the edges of the skin together over the wound as you stitch, until the tear is all closed up. Nany times 1 have taken as many as fifty stitches in one wound. Bathe the wound with witch hazel every day for four or five days. It is well to keep the hen in a small pen or coop for three or four days where there is quiet, and where you can eateh her without running. If you gave her free range she might tear out the stitches. The period of confinement depends entirely on the size and nature of the wound, but as a rule, after three or four days sle can be liberated with the rest of the floek.

\section{FOOD FOR YUUNG TULEYS}

As a rule, many young turkeys are killed by overfeeding. On large farms where the hen turkey and her poults have plenty of range, it is best to feed them only twice each day, onee in the morning and again at night. Young turkeys can live on insects and many little grasses which they relish. Fou will always find that food they get in the fields will keep them in hetter condition than anything you can give them. During the berry season, especially, when wild strawherries are ripe, it is a pleasure to wateh the little turkeys pick and eat them. In seasons when there is a good supply of grass- 
hoppers, the turkeys will live almost entirely on them. When young turkeys have to be fed the best food I know of is stale bread, but be sure the bread is not sour. By stale bread I mean wheat bread three to ten days old. Muisten the bread with sweet milk, but do not get it too moist. I usually press out all the milk that I ean with my liands. Clabbered milk is also goorl tor young tme lieys. Put it in a dish on the ground where they ean get at it easily. During the warmest weather of summer it is best to keep all turkeys. young or old, on the hungry sicke, for if you do not, there is great clanger of their hav ing bowel trouble.

I have told you how to eare lor turkeys on a large range. If tou are on a limited range, or for any reason you have to keep your birds confined, I mean young poults, take three hoards twelve or fourteen inches wide and ten $M$ twelre feet long and make a triangular pen. In this pen put the ofk inkey and her poults. Do not tonfine the hen. She will jump out and in orer the buards ancl will not leave her poults. It is best to leare the poults in this pen for fifteen to eighteen days, and then let them range with their mother, Nany persons think it is necessary to put the hen turkey in a coop to keep her neal her young, but this is not the rase. as the mother will stay with the poults; you could hardly drire her away. When the young poults are eonfined in a pen as aluve described, it is neeessary while so young to feed them four times a day with stale bread moistened with milk. If the weather is rainy and wet, it is sometimes well to use red pepper ennugh to make the bread quite warm. If any of your poults are drooping it will tone then up. Clabbered milk is also good for them Should pou find that the young turkeys are drooping and do not seem to piek $m$, the rery first thing to look for is lice. If your poults nave lice or ticks they will not do well, and it is almost impossible to raise them. You wili find at times a large blue tick on turkess and turkey ponl1s; they are on the meck and head only. If yon shonld find any ticlis on your poults, pick them off, then use clear lard on the head and neck. It will kill the nits that woukl hateh if you did not nse some preventive. For the two other rarieties of lice, use any rood insect powder, but always be careful that none gets in their eyes. Hen turkeys generally keep free from lice if they ean find any place to dust themselves, but some a re very lazy and? if these hens have poults they will be sure to be infested with lice, too. In looking for lice it is best to examine the little wings, as generally you will find them at the base of quills, also around vent. For the terrible ticks, which are almost sure death, look npon the neek. push back the feathers carefully until you reach the top of the heal. You can easily see them, as they are good sized, and the older ones are dark blue in eolor, usually full of blood. If you keep your ponlts free from lice you will have overcome almost all danger of loss.

Stale bread moistened in milk should be fed to the poults for three or four weeks, then gradually get them to eat whent and fine cracked corn. This grain should be scalled, as it will then assist digestion, but do not feed it until it has thoroughly cooled. Indigestion is very prevalent among turkeys, both young and full grown.

If rour poults slould have diarlioea from any eause, one feed of boiled riee will usually stop the trouble. Another common but sure relief is to give them red pepper, say one tablespoonful. Mix it with about two tablespoonfuls of wheat middlings, then moisten it with water, but do not wet it enough to make it sticky. Cut it up in about four to six prots and roll the parts into pill shape, put them in an oven and bake them hard. It is well to have a few always on hand, as after baking they will keep for a long time in a dry place. If I have a turkey, either old or young, with a bad ease of diarrhoea, I give one pill three times a day until the cloppings are improved. Then gire a tablespoonful of castol oil if the turkey is full grwwn, or a teaspoonful to a young poult. It is very seldom that 1 camot stopl a case of diarrhoea with this treatment.

\section{F. 11, FEEDIN:}

I commence to feed all turkeys the first of October to get them ready for 'Thanksgiving, as we all linow there is more demand for turkeys at that time than at any other. They should be fed norning and night, but never more than thes will eat within a few minutes. Most of the truble we have in the fall is caused ly orerfeeding. At the time you commence to teed for fattening use common sense and feed lightly for the first ten days, gradually increasing the food. The principal food from October to January first should be corn, not eracked, and the older the corn the better, as new corn will eause bowel trouble. I have seen large flocks of turkeys knoclied out hy feeding new eorn. If you gret their bowels ont ol order, it takes weeks to get them in gond condition again. Is a rule, most of your turkeys will be fat and in good eondition to dress at Thanksgiving. There way be a few late hatched broods that will be improsed if carried orer to Christmas.

Many people adrocate putting tur'keys in a closed pen to fatten. I have giveu this method a good trial many times and under all conditions and find it a failure. Let them have all the range they want. The results will be better and yom will aroid the sicloness they will have if you confine them. Many persous do not understand why their turkejs are not so fat as they shonld be, but almost invariably rou will find that they have fed them in confincment and the turkeys could not stand it, especially for a period of several weelss. They get off their feed and will not eat. In the fall when the weather is cold, turkeys will not range far from the farm buildings. They will eat their morning food, then roan around after a little grit to help, them digest it and then lie down in a warm place out of the wind. Drive all the turkeys you wish to kill in a harn or shed so as to contine them twenty-foul hours before killing with no food of any kind. To look well when ilessed, their crops must be entirely free from food.

\section{TIE BLNT ROOSTINA I'LACE FOR TURKLYS}

Many persons who keepl turlieys think they need shelter in the way of a building. That idea is entirely wong. The hest possible way of keeping turkeys in good health is to have them roost away from buildings, in trees if you liare them. Iry rousting in trees they will not he in draughis, as they would be if allowed to roost in sheds or huildings. I have known turkeys to roost in trees with the thermometer fifteen to twenty degrees below zero, and be much healthier than turkeys that were inside a building. A turliey can stand auy weather we have in the Lnited States if they are roosting in trees that are partly sheltered from the wind. I hare seen turlieys in trees during a snow and rain stortu with the wind blowing sixty miles an hour, and they did not appear to mind it in the least.

1 great improviment has been made in the size of turkeys, especially Bronze, in the past twenty years. The ordinary turliey of some years ago, as bred by the average farmer, would weigh alomit as follows: Toms, twenty ponuls; hens, eigint to ten pounds. Today Fronze turkeys will weigh: 'Toms, thinty-five to forty-two ponncls: hens, eighteen to twenty-five pounds. This shows what proper mating will ilo. 


\section{IN NATURE'S WAY}

Selecting Breeders-Introducing New Blccd-Raising Brecters-Avoid Crossirg, tut J dicicusly Inbreed-Poults in Nature's WayRange-Food-Housing-Difficult Sections to Breed Correctly

\section{B. F, ULREY}

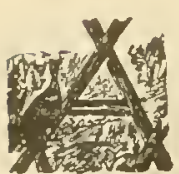

S I BREED only the Bronze variety of turkeys, and a limited number of them for exhibition and breeding purposes, and as I have had no experience with any other variety and never sell on the market, except the culls of my flock, I cannot give you much information on raising turkeys for market. However, if I were to breed turkeys for market purposes, I should employ the same methods as I do in breeding exhibition fowls, except that I should not discard a good bird if it were faulty in color. Mrost farmers, I notice, sell all of the early hatched turkeys on the market because they will bring more money and they retain the late hatched and immature ponlts for breeding purposes.

The consequence is, they do not raise many next season, because the breeding stock has no vigor and the poults no strength when hatched.

I have bred Bronze turkeys for ten years and my method of raising them is entirely different from that employed by anyone with whom I have talked, or from the methods of poultry writers which I find printed in the poultry journals from time to time. In the first place, I keep about fifteen females in each flock, seven hens and eight puliets, headed by an adult tom, assisted by a cock. erel, and $I$ always have fertile eggs. The Bronze turkey commences to lay when she is about ten months old and she will lay from twenty to twentyfive eggs before she offers to sit, then if confined for about a week or ten days she will commence to lay again and will lay from twelve to sixteen more eggs before she becomes hroody. Most hens lay two clutches in a season, though I have known some hens to lay all summer, and $I$ have one hen that laid ninety-seven eggs from $\Lambda$ pril first to September tenth. In selecting my breeding stock I take females as near Standard weight and color as possible, having large frames and bones and such as are not too fat. These are mated with toms that are a little above Standard weight, the cockerel weighing from twenty-eight to thirty pounds at ten months old, the yearling cocks from thirty-five to thirty-seven pounds, the adult from thirty-eight to fortytwo pounds. I am particular to have males of the best color and shape I can get. I find that the female gives us size, while the male governs the plumage. In changing males and breeding for exhibition purposes, I always try to get a tom that is extra fine in the sections in which my females are defective. The best way to introduce new blood is to pnrchase a female from some successful breeder and mate her with the tom that heads your own flock. Sare her eggs and mark her poults, and if they prove good, yon can use them successfully. On the other hand, if you buy a tom of another strain (the male counts more than half of the flock) to mate with your hens, and such mating results in poor hirds, you have lost the seasou. I often see advertisements in poultry journals in which breeders offer stock for sale produced from twenty-seven to thirty-one pound hens and forty to fortyseven-pound toms. Such claims are intended to catch amateurs, for any breeder of experience knows that a hen that weighs twenty-seven pounds never lays fertile eggs, and a tom that weighs forty-seven pounds never fertilizes an egg.

\section{HATCHING AND RAISING POULTS}

I allow the hens to have their own way about their nests, although I place barrels on their sides along hedges and in secluded places in the orchard and fence corners, in each putting a small quantity of straw. The hens generally nest in the barrels and $I$ remove the eggs every day until the hen is heady to sit. I then give her seventeen eggs and at the same time put ten eggs under a domestic hen to hatch. All the poults are given to the turkey hen to raise, as I find that a turkey knows more abont taking care of ponlts than $I$ do. I give her a good feed of corn and a drink of water and then let her go where she likes. If there is a meadow or pasture within three-quarters of a mile, that is where she will go. I have one hen that hatched sixteen poults and I gave her nine more hatched by a domestic hen and she raised twentytwo of them. I have never seen a fence that will confine turkeys unless one wing is clipped, then a four-foot netting with a barbed wire above will keep them confined, but I do not wish to confine my turkeys except occasionally for a short time. Once in a while I have a hen that wanders too far from home to build her nest. I have an orchard covering about two acres which is inclosed with netting and barbed wire and in which I keep my Silver Laced Wyandottes during the breeding season. I bring the wandering turkey home, clip her wing and put her in the pen described until she lays out her clutch. If a hen and her brood get to running away and going to a neighbors', I put them in the chicken yard for about ten days, after which $I$ have no further trouble with them. I look after the hers with poults on bad days when I cannot work in the fields. If I find any weak poults I examine them for lice, and if $I$ find any lice $I$ give the poults a good dusting with insect powder. If the weather is dry, the poults find enough dust in which to wallow to keep down the lice, but if it is wet weather you must look ont for lice. I am satisfied that nine-tenths of the poults that die are fed to death or are killed by lice. 


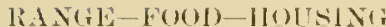

I give my turlieys unlimited range and feed nothing until July 15 th, tlien I drive them home every night and give them a little corm. In about a week they will come home at night for food and to roost and I have no further trouble with then until I am rcady to sell or show. Some writers claim that wet weatlier and heary dews are fatal to poults. If such were the case I should not have a poult today, as the past season was the wettest we have had in several years. Still I have more poults now than I ever raised before in one season. I have never had but two sick turkeys during the years I have been iu the business. One of these was crop-bound. I poured about a pint of warm milk down her throat and kneaded her erop with my fingers for about ten minutes, then gave her a tablespoonful of castor oil and she was all right the next day. The other was a three-year-old tom which dropped not eat a half bushel of corn a day during the week I fed them.

Never discard a good bird because it is getting old. I hare known hens to be first-class breeders when seven years old. 'The best tom I ever owned, both as a breeder and an exhibition bird, I sold when he was three years old because I thought he was getting too old for a breeder. The person to whom I sald him used him two seasons and he proved a successful breeder. Then this man sold him, thinking he was too old for breeding or showing, but his new master thought differently and showed him at Madison Square Garden, New York, that winter when he was five years old, and won the blue ribbon. Old "Champion" has a record of eighteen first prizes. He weighed thirty-five pounds as a yearling, forty pounds as a two-year-old and forty-three pounds when four years old. He was the sire of the first prize

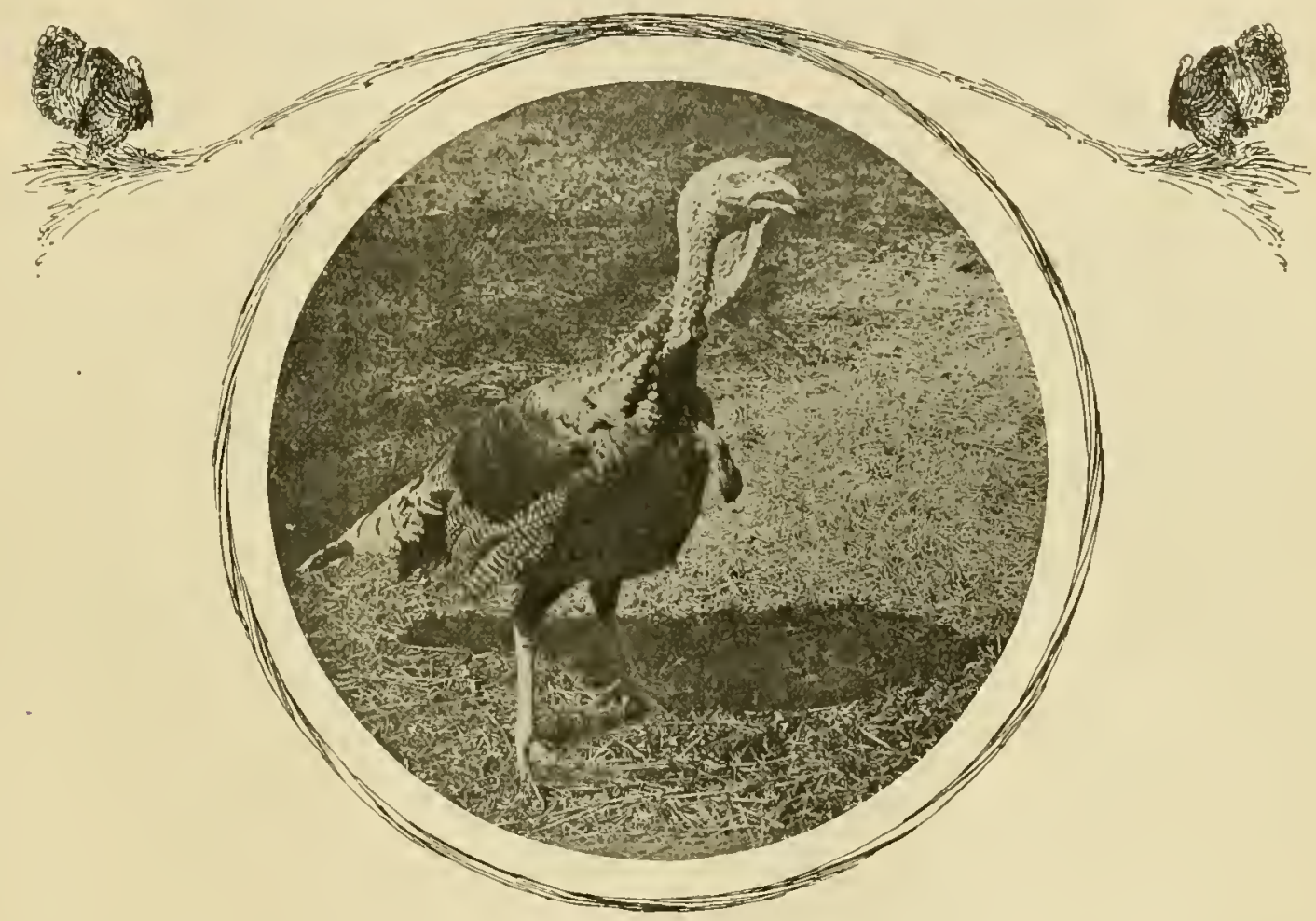

Chatupion Jr. One of B. F. Ulrey's Chicado Cup Winners. Score 97 Points, by B. N. Pierce

off the roost dead. I commence feeding my turkeys all they will eat about November first and continue feeding until about February first, then I let them hustle for their living and they will be in good breeding condition.

I never house turkeys, as the trees and fences are the natural roosting places for turkeys and $I$ think that the nearer they are raised as nature does the better' the results. Turkeys cannot be raised successfully without plenty of range, as they must have exercise and a variety of food, which they cannot obtain except on an extensive range. If you will examine the crop of a poult after September first that has liad plenty of range, you will find grasshoppers, bugs and worms, together with several varieties of weed and grass seeds, but very little grain. Some persons claim that a turkey will eat more than a hog. I had a chance to test the matter last winter when I had sixty-five turkeys on hand and there came a severe snow storm which prevented the flock from getting anything to eat except what I fed them. The sixty-five did cock and second prize hen at Chicago, January, 1900, and to my knowledge, was the sire of eleven turkeys that scored 97 points or better.

\section{ATARTING TUE LUSINESS}

If I were to start in the business of raising turkeys, having the experience $I$ now have, $I$ should purchase three or four of the best females $I$ could find that were near Standard weight and as nearly perfect in color as I couId find. I should also buy their sire if he had proved to be a good one and should mate them to him. If I could not get the sire, I should get a cockerel from the same mating that the females were from and should mate him to the females. Then I should save the eggs from the best hen, mark her poults and save a tom from her to mate with my flock the next season. The pullets I should take to another farm and mate to a tom from the home flock. In that way I could line-breed and not in-breed too closely. When I saw there was need of new blood, I 
should purchase a femalt from the breeder of whom l purchased my original stock, and in that way I wonld keep the same strain, but my birds would not be near enough related to affect their health and rigor. Is surely as you introduce a new strain in your flock, you will lose both shape and eolor and it will take at least three years of eareful mating to get luack where you were when you made the cross.

I find that the breast and back are the most diffieult seetions to breed eorrectly in regard to shape. Is a rule, the back is too narrow and too short. We want our birds broad aeross the shoulders with a long back and full round brenst, lather long legs and large feet. In color we have the most diffienlty with the wings, tail and baek. The Standard says in regard to eolor of wings: "Primaries - Fenely feather evenly and distinetly barred aeross, with parallel bars of black and white exteuding the entire length of the feather:" Of the coln of the tail it says: "Dull black-each feather exenly and distinctly marked transversely with parallel lines of brown, each feather having a wide blaek band extending across it near the end (the more bronze on this band the better) and terminating in a wide erlging of white." Now I find if we get a clear white barring in the wings we are sure to get white barring in the main tail feathers, which is a serious defect. In fact. I shonid not keep a bird for a breeder that had white barring in its tail. I also find that if we get a clear white elging on the tail and tail euverts we do not get a rich bronze on the baek and tail eorerts, and if we get a good bronze where the Standard demands it, we are sure to get smutty white on the end of the tail and smoky white on tail coverts.

\title{
TURKEYS RAISED WITHOUT HOUSING
}

\author{
Confining and Housing 7urkeys - Turkey Eggs-Care of Pouls-Feeding Corn-Diseases-How to Begin
}

\section{B. F. IISIOP}

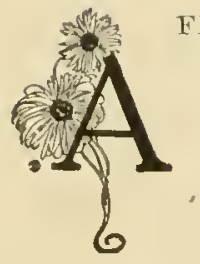

FEW years ago when we finally concluded to try turkey raising, we had already decided that the Bronze was the variety which suited us best, and we bought a trio in the fall in order to be ready for business the following spring. We had no exprience, so we began to read uj, on the subject and to question oul neighbors about their methods uf caring for the young. We found that most of the neighbors allowed the lurkey hens to do all the work. and when winter camc, if there was a large llock of turlieys the farmer's wife elaimed all the credit. but if the turikey hens failed to raise large families. they had all the blame. At first we raised the poults with domestic hens and later decicled to try the turlseys, but found the old ones so unruly that we again gave the punlts to the domestic hens. The worked according to rules, kept the coops well scrubbed, ete, and we succeerled fairly well, raising as large a percentage of poults as we have ever raised since, but the work we did that year, if applied to some other ealling, womld have ubtained us far more money, and we concluled if raising turkeys required so much work we had better quit the business. The time we wasted doetoring eolds that season would have discouraged most amatemss. We were af 'aid these colds might derelop into roup, and so labored most patiently. We wish to say that we do not believe turkeys ever have loup as ehickens do. We think the birds become debilitated from injudicious treatment from the time they are hatched. and when autumn comes the birds take cold, which develops into ehromie catarrh. We do not believe it is contagious, but a flock will be more or less affected. as all the birts are exposed to the same canses. It is hare to eure such colds, for if a man does not know how to provent his fiock from taking eold he is laadly likely to know how to eure them. There may he flocks that have the roup, but we hare nerer seen any, though we have seen birds whose owners thought they had roup, but which we beliered to be suffering from a severe eold.

This year not one of our turleys has a cold, although this is the senson for it, and we think we understand why they lane escaped. In the first place. we elnanged the bloorl, as we believe inbreeding produces weak stock, although one does not neerl to make too great a change.
We do not think the turkeys are as liable to be off in color as ehickens al'e, and so we have no hesitaney in putting a fine tom at the head of our flock without tracing his pedigree. I tom will do a large part in elevating a flock, but he annot do it all, beeause much denends on the females. The male, so our experience teaclies us. las mueh to do with the size, with the length of the lones, markings of the tail and wings, and also the shape of the body, hut if the females are too small ami poor. $y^{\circ}$ marked, one camot expect anything tirst-class from such a mating. I large pereentage of judges are icry particular about the markings of the tails and wings of turkeys, so one has to look after these sections. Some judges are very particular about ha:ing a good bronze. althongh shape, size, cte., wil] help one ont, but the best judges want a bronze, not a black or brown. Many breeders eannot, see bronze in any but their own bircls, but when the birds are all together in a show room, a person, if he has an eye for beauty, can select the bronze birrls, and so ean the jullere-which is one good point for comparison jurlging.

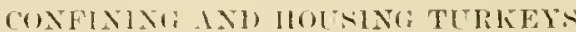

We do not think turlieys can be raised in large floeks without a large range, although we have never tried rasing them in continement. I turkey is naturally a forager and in roaming abont procures its proper food. Even if a person las solved the food problem (we do not think we liave) and confines his turkeys, intending to feed them, le wombl prerent them from taking the proper "hereise which they require as much as they do food. if they are to attain the greatest possible size and rigor. We fund that the lack of size and rigor is to be seen in poults raised by domestic hens. We lave been asked if it is best to house turkeys. We have never housed them ourselves. 'lhey lave always roosterl at night in the trees and lived aromd the buildings during the day, but we intend to try housing them sometime because from what we have learned we think it would be a good plan. Wro sinall use sheds open to the south, with trees for protection on the open side. We have a grove that is a great protection to our flocks, but we think they need more. Whom a birl stands around on a colu, li]eak day, all fr:iтn up and then goes to sleep on a naked limb, with 
the wind blowing a blizzard around him all night, we cannot see that it is of any benefit to him. He has the same surt of budy that other stock has and if he has no shelter to keep him warm, his food has to do it. Plenty of fresh air does not mean that birds must be out of shelter. We do not think that over seventy-five turkeys in one flock will do well and we prefer fifty or less. It does not matter how early turlieys are hatehed. The hens in this climate will not commence to lay much before the first of April. and the later hatched will lay about as soon as the early ones, unless very late hatcherl.

\section{IN REG.IRD TO TITREYS}

We ro not lieep the young birds for breeders becanse they are not matured enough. Ireeders should be at least ten $n$ eleven nonths olk, the older and more mature the fowl is, the better the breeder. We may not get so many egrgs from the females, hut we get better ones. The one draw-baek to two-yenr-old turkeys and older is that we let them get too fat in this torn country during the winter. We have never been able to seeure such large clutches of egas as some claim. We get an arerage of twelve in the first ruteh and alwut ten in the second. Somo hens will lay more, and some will lay three clutebes, but they a le less in number and we nerer count much on them, for the hens usually hide their nests and we seldom bother about them. Oecasionally a hen will lay a large number of eggs, in faet, will lay all snmmer, but snch eggs are sordom fertile. We have mated fifteen females with one tom with good results, and we do not helieve there was any larger percentage of infertile eggs than when we materl a tom with two females. Turkey eggs are usually fertile if the hens are not too fat The put onr hens on "starration rations," as we call it. when

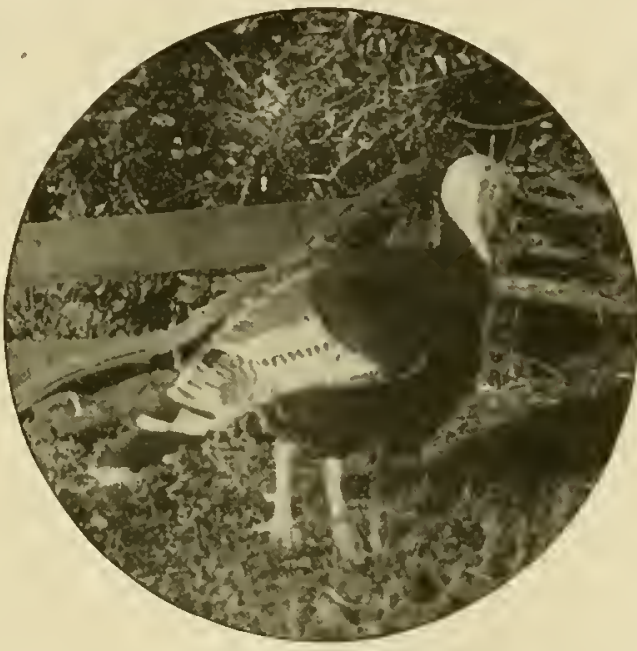

First Prize Youn Tom

Chicago and Indiana State Fair. Bred and Owned by F. B. Hislop
CAliti (1) TOULTS

We used to keep the poults and the mother hen penned up for about ten days or two weeks, feeding the roung turkes three or fonr times a day on boiler eggs, dandelions, curd and brearl soaked with milli. They did very well, but we think now it wa a mistalien kindness. for we lost a larger yer cent of the young in the fall. We think that with all our care we invariably overferl, but they dicl not show the effeets until fall. Now we make a practice of keeping the hen and poults penned up four or five days, feeding very sparingly on boiled eggs, dandelions or any green plant, sich as onions or lettuce, ant a little breat, We have disearded curds altogether as we think it is too nulch work for the benefit, in fact, we have almost comcluded that it is a detriment to the furkeys, for when we fed it we were bothered by the fowls having worns more than we are now. This season we went to very little trouble to feed them after the hen was set at liberty. If it were convenient we fed them twice or three times a day, but if not, we looked after them at erening to see where they roosted, and fed them, giving then some lind of cooker food, ontmeal, and bran. ansl later a mash composed of equal parts of corn meal. middlings and hran. with a little meat meal, hune and renetian red. The food we gave them was so little that we dicl not consider it necessary. and as they grew older they did not hare use for it, lut we still fed them in order to keep them tame and teach them that ther had a home. Nerertheless, we frequently harl to drive them home. A turliey on a fal'm range will take cure of her floek and raise them strong and vigorous with very little foud from the house.

There is much ado abont young poults being killed by danp weather and by being out in the dew. $3 y$ the time a turkey hatehes in this climate it is not likely to be nearing the breeding season. It that time we feed mostly oats, meat aud regetables. Turkey eggrs incubate in twentr-eight days, and when the weather is very warm a day or so less time is required, but we do not remember ever luving one sit orer twenty-eight days. Turkey hens seldom hide their nests for the first chutch. In the second they male the attempt, but we wateh them and if they want to go too far away we drive them nearer home and thus gret then to commence laying in a nest more conrenient to us. We gather the eggs and keep them in a corl place, placing them on the small end, and if we should keep them long. we turn them, but as a rule, we do mot keep them long enough to take that trouble, fro if we do not set them ourselves, our customers are waiting for them. We have generally had better success in putting eggs under clomestic hens, but we do not let them raise the poults. We always have a turkey hen waiting to take them. If a turkey hen has been sitting two weeks, or eren less, she will take the young if they are put under her when a few honrs old. We have trier putting pipped eggs under the turkey, but too many of them grt mashed, so this year we waited until the poults were a few hours old. If a turliey chooses to sit in the proper place, we put egos uncler her and set a domestic hen at the same time, but give all the poults to the turlkey, very coll. and unless the groum is so low that the land is flowled, there is little danger from rains. This has been a rery wet summer in our locality, and we had hens out in heary rains when the ponlts were but a few days old and we clid not lose a poult nor did the young get wet. We have a large orehard and grove that furnishes a great leal of protection, but often the hen sat out as far from the trees as she could get, not to entirely leave the orchart, still there were no poults drowned. We think move regularly, as they cannot hunt for their food. We hare lost more young by having the old hen go into a coop with a palt of the flock, the other part being left out and drowning, than we ever did when the lien was ont with the flock. After the frosts kill the bugs, grasshoppers, etc., the turkeys require more food, and we feed them morning and night a small ration, increasing it as the food in the meadows and pastures decreases. In the morning we feed a mash with the same ingredients that we fed to the poults while young, with the addition of charcoal and oil meal in small quantities. We also give them cracked bone and grit, all they will eat of the latter, and at night eonse eraeked eorn and soaked oats. Now if the young poults are not fed to death, so to speak, there will be little, if any, indigestion, and if a case now and then appears lessen the food, and in individual cases during such wet spells that the poults need to be fed 
give the fowl a full tablespoonful of castor oil with from fire to ten drops of turpentine in it. If one dose is not enough, give two or three, or even more, one dose a day, and search for lice. We have invariably noticed that the debilitated fowl always becomes lousy and generally has worms, as these pests invariably follow indigestion.

\section{FEEDING CORN}

Do not begin too soon to feed corn. Last year we fed our chickens considerable cracked corn in the outside scratching pens. Onr turlieys soon learned this and were on hand by three or four o'clock, if they had not hung around all day waiting for evening, and they got a large share of the corn. As a consequence, we lost a lot of fine birds from indigestion. We could not cure it, as we did not remore the cause. We wanted fat chickens and we paid for them with our best turkeys, but we learned our lesson. lieep your turkeys going out on the range as long as possible. Drive them away in the morning if they will not go. When the weather becomes cold and the proper time for fattening comes, then feed corn and heary grain. We would never fatten the birds intended for breeders if the purchasers did not demand heavy weights, as fat is a detriment to the birds. We cannot blame the purchasers, as this is about the only way they can.be sure of getting a large fowl and so they call for actual weights; but the tall, rangy, well-shaped, long, coarse-legged turkey, even if he does look slim in the fall, is the one that will be a large bird. Our first turkeys purchased were low, blocky birds, and they were almost as heavy in the late fall as they ever got. We thought them fine at first, but it did not take us long to change our minds, so that the next autumn we purchased a trio of birds from a well-known breeder. When they came the fowls were but a pound or two heavier than our old stock, but they were long legged, awkward, green looking birds, and we were plcased with them, for we could see into what they rould derelop and we were not disappointed. Since then we have known better what to purchase. Turkey raising is like a great many other things. One can read a great deal about it, but the actual experience is necessary. Nore than that, it can never all be learned, nor does one person possess more knowledge than all other turkey raisers combined. The longer one is in the business the less conceited he beconres if he has any success.

\section{MARKETING TURKLS'}

In catching poults or old turlieys, one must catch them by the legs, holding them just below the hocks with the legs together, laying the birds across the arm if you wish to carry them, or on something else if you do not. The cost of feediug a turkey on a farm does not amount to more than 50 cents per head, eren with all the extras a breeder needs, and the farmer's wife who lets the turkey do the raising is out so little one cannot estimate it. We purchase food for all our poultry together, using as we need it, and consequently when the time to balance comes we simply count up our expenses and income from all our flocks and look for the gain or income. When turkeys are raised for market, the heary ones will pay the most profit fattened and sold for Thanksgiving and Christmas, but the younger and lighter weights that are not in as good condition as they will be later, can be marketed any time during the winter, as the turliey market does not fluctuate so very much for good stock. We have lad dressers of poultry tell us that the Bronze turkeys were the finest they handled, but we do not believe they command a higher price than other varieties, all conditions being equal. Good dressed turkeys bring from eleven to twelve and one-half cents a pound in Chi- cago. Exery breeder should dress his own fowls, as it will pay him in all instances. Have the fowls fat and do the work nicely and you are sure of the top price.

\section{LICE WN TLRKES}

Wie have not touched the lice question in regard to young poults. We are not much in favor of greasing, except in using a little lard on the old heu when first taken from the nest and on the tops of the poults' heads as a preventive of head lice. We dust the old hen two or three times while she is sitting, and thoroughly when we givc her the poults, then watch the young and as soon as we see lice on then, dust them with good insect powder, aroiding the white, as it makes them look shabby. We do considerable dusting, once a week for a few linonths, but oftcner if the lice compel us to. Dust the old hen, too, for when the lice are destroyed in this way at the begin!ning your trouble is orer. We catch the young by laving a box trap. Feed them in a bunch and when they commence to eat set the trap over them, the top of ue box being laths witn a little trap door in it so we can take the poults out one by one, dust them and let then go. In this way none are missed. It is not so easy to catch the old bird. Occasionally she escapes a dusting. but we manage to get her often enough to prevent trouble. We seldom have a sick poult, so we never experienced pulling wing feathers. Our trouble heretofore has been, as we said, in the full, and ve think we can steer clear of that better than we have.

\section{DISLASES OF TURKEYS AND RANGE}

In our experience the diseases of turkeys are brought about by impaircd digestion. If one can build up the constitution and remove the causes of the trouble one can cure many of them, but when the constitution has become thoroughly broken down you might as well use the ax and stop the misery. Do not be too hasty, however, as many of them may be cured and marketed. Colds are not necessarily fatal, nor is rheumatism, although the latter is worse, but when a turkey gets the black head he is often dead before one gets a chance to doctor him, so the best way is to begin right and aroid such trouble. A large flock is more difficult to landle than a small one. We do not aim to raise over seventy-five in our home flock, as the range is not good on the prairies and the pastures are too small. We all know that a large cattle pasture is an ideal range, but they are not to be found in a locality like ours, where land is high and it is all under cultivation, busides one's neighbors do not like to see another man's turlieys in their oat fields or corn fields in the fail, although it is a well established fact that turkeys eat mole injurious insects than they do grain and they are a benefit rather than a detriment, but you can not malie many farmers helieve it, and it is useless to try. We are trying to console our neighbors by compensating them in some way for the imagined damage, but with all that the yellow cur puts in his appearance occasionally and chews up a fine bird. It is not all clear sailing in the turliey business, and as we are located, if it were not for the pleasure we take in seeing a fine flock of the mammoth beauties, we should quit the business.

We do not think swampy ground would be a good lilec for turkeys, especially during a wet season.

There las been a great deal said in regard to the size of the Bronze. Many think the present Standard weights are high enough and we have heard of judges cutting birds (toms) for being too heary, same as too light. Now this surely is carrying matters too far, as size is one of the main features in a turkey (or any domestic bird that is cut when under Standard weight for that matter) as long as we retain shape and plumage. We have never 
struck such a judge in our exhibiting, and when we do, there will surely be a noise. Hen turkeys may be too large and masculine to be good breeders, but even they can be from two to four pounds over standard weight when in good flesh and yet be very desirable breeders. As for an adult cock, we don't think 40 pounds would be too heavy for Standard weight, and birls that reach 45 or 46 pounds are just as good breeders as those of Standard weight.

One cannot expect to retain size in his Hock if he does not stick to large males for breeders. In occasional use of a small cock with large females may be necessary to secure some desirable feature that the breeder is more in need of than size, but the latter has bothered us more than any other point, as our customers are always looking for the big bircls, even at a sacrifice of other qualities; especially is this true of the marliet breeders. We fanciers are always looking for the birds that win the blue ribbons at our shows, but nevertheless we eannot affor? to let the market qualities go unnoticed, as all out birds after all are bred for the common market in the end. One thing the prospective purchasers, old breeders as well as amateurs must learn, is that weight does not always mean size. For instance, two turkey cockerels una each weight 25 honest pounds, but one may be a large bird and the other small. The birds may both be scored and taken on an average. There is very little difference as far as the score card speaks, but compare the two. (bive :asiy be worth wice what the other is to a breeder that wants size as well as other points.

A score card show will not do justice to Bronze Turkeys, and the breeders of our most popular birds, the large, fine ones that are in demand all orer America, know this; if they don't, they will soon learn it.

The kind of turliey judges we want are those that consult the Standard for plumage, shape and size, but for the latter we want a man that can see size without putting the bird on a scale and weighing it, as the scale has to conside. the fat along with the bone and muscle. Nor does it tell you how much of each there is in the bird considered. The Standard has no other way of fixing the size, save by weights. The rest is in the hands of the judge, and he is supposed to know the meaning of size.

\section{live THE MLTELII}

Were we to start in the turkey business, linowing what we do now, we should buy the best breeders we could find that were fur sale at a price we could stand and would not be afraid of a few dollars if we could afford it. We should build a shed for them, and if we did not have some lind of a grove we think we could ill aflord not to build. We should start with the Bronze, for considering all we know of other breeds, we still like them best, and think that we can make the most money out of them. The market man prefers them for their size and the fancier for their beauty. Judging from the numbers shown "in our exhibitions, they' are the most popular variety.

A word to purchasers-when you wish to buy, first select a reliable breeder and if you want breeding birds fou can easily purchase them at a reasonable figure, but if you want show birds for breeders (which are the best) do not expect them at common breeding stock prices, for no man's whole Hock is composed of show birds, even if many of his old breeding stock were once show birds. If the breeder tells you that his birds were never beaten in the show, immediately learn where the birds were exhibited, whether in a loeal show or in a show like Chicago, New York or Boston. No person has made a clean sweep at many large shows unless the competition was very small indeed.

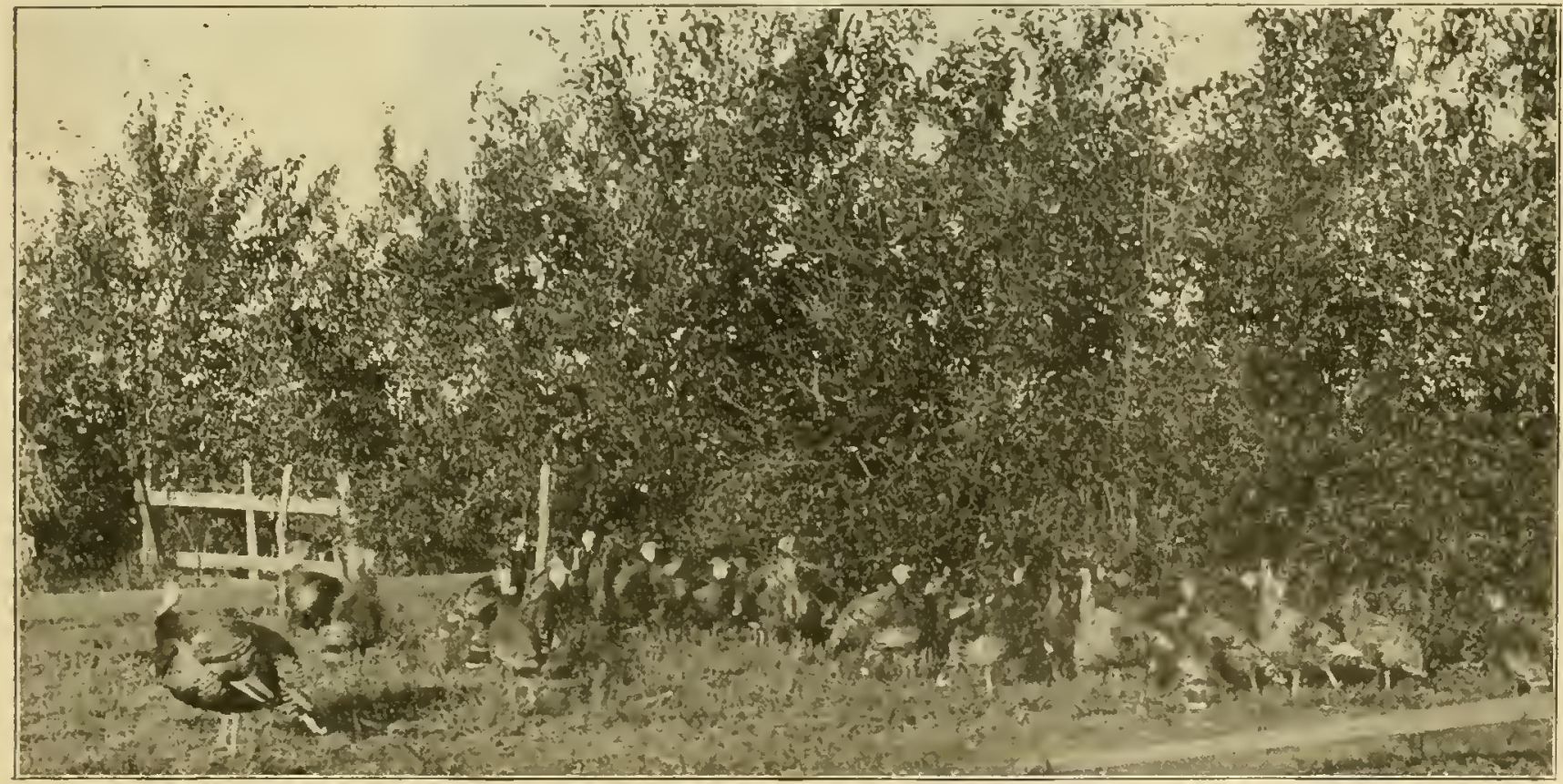




\title{
MATING STANDARD-BRED BRONZE TURKEYS
}

\author{
Desirable Qualities in the Males and Females-Number of Females in Pen-Evil Effecls of In-Breeding
}

\section{J. T. THOMUSON}

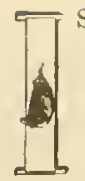
THERE any lind of live stock on the farm that is more beantiful to look on, or more profitable to raise, than Nammoth Bronze turkeys as they are bred today? 1 believe that you will answer in the negative, for they bring more per pound than other live stoek and their flesh costs no more; in fact. 1 do not believe it eosts as much to raise them. 'Fhey are great rangers and they obtain most of their liring from foods that you would not otherwise realize on. Males weighing from forty to fifty pounds each. females of twenty pounds or more, that are beautifully and delicately marked, and with that rich bromze color and proud earriage, are certainly admired by everyone.

History tells us that in the winter of $1620-$ about a year after General Bralford and the pilgrims landed on our eastern coast. and after having endured hardships that only the strongest and brarest could survise, they set aside a day to offer thanlis to Him for bringing them through such diseouraging tinjes-on their first Thanlssgiving, tle pilgrims ate wikl turliey, in preference to the meat of the ells, the deer, the bear or any of the other wild animals that were plentiful. While that is nearly three centuries ago, 1 am glad to know that from that time to the present the tlesh of the turkey has been more honored than any other fowl that we raise.

The Nolth Ameriean forests being their native home, they were, nevertleless, raised in many parts of Europe within three

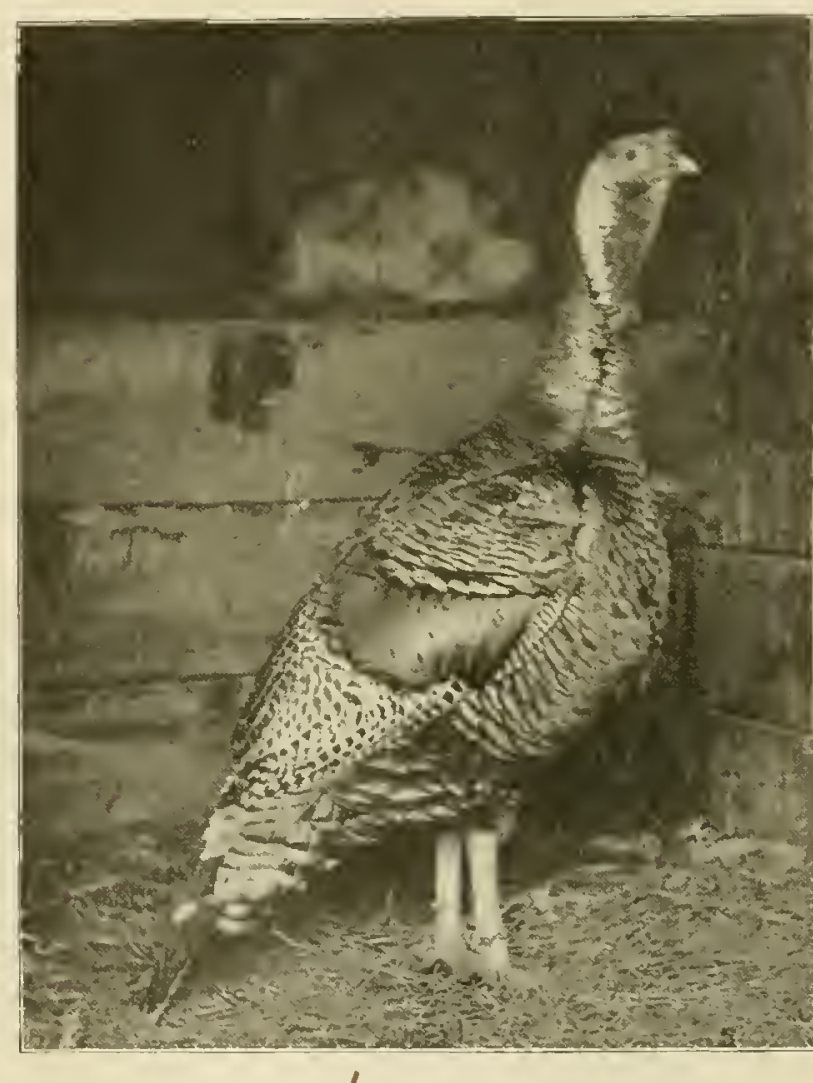

Exlubition Mammoth Bronze Turkey Tom Bred and owned by J. T. Thompson that we have won at the leading poultry shows, eertainly proses that our eftorts hare not been in rain.

\section{ILTING: T'TRKEY}

lil mating turlieys select those that have large, broad heads, long necks aud bodies, big feet, and as well liealls. long nerks and bodies, hig feet, and are as well as well marked as rom can get them. at the same time, never discount a porr? marked hen if she is of good size and shape. for if the tom is well narked, he will, to a sweat degree, orerome this defeet. 'l'he same is true with a poorly marked tom mated with well marked hens.

Never breed from a short turker, for while they fatten more quickly and look larger than the ramgy nue of the same age. it is the latter when fully matured that makes the big ones-the kind that we all want.

If rour turkeys are large, but not as well marked as they should be. $o r$ perhaps they are a little off in color. and yon have a strong entored tom that is somewhat small in size, it is all right to use him once to breed out such defects. However. you eannot afford to continue to breed from suall males. for the size of your stock will certainly decrease. Is the breeder who mises for market purposes demands size, and since the Standard ents more on size than anything else, it is evident that it is the main consideration.

\section{NIMUER OF GEMALEN IN PEN}

Never mate more than twelre hens with one tom. iears after they were diseorered here. This proves that the people of the old worid like those of America. were not long in discovering the fine flavor of this royal fowl.

\section{IBREEI FOR EXHIHITION QI DLITIES ANU SIZE}

When we began raising Mammoth Bronze turkeys rears ago, our ohject was to breed them for exhibition qualities as well as for great size. We believed that in order to make the greatest sucess of the turliry business, and to realize the most money from it that we nust combint the exhibition and utility qualities. For the past seven years, our toms have weighed as yearling birds from forty to forty-five poumls, and our hens of similar age, twenty pounds or more. The high honors
In my: upinion eight is the right number for the average male. I hav known of ases where good results were ohtained hy mating twenty and twenty-five liens with one tom, lut such eases are exceptions and not the rule. Yever let two males rm in the same yard. If you have too many hens for one tom, and do not wish to mate two varls, you cin arrange it ly having one of the males in the yard and keeping the other pemed up for three or four days. 'The birds should then be ehanged, and the one that was in the vard slondd be eonfined and the other placed in the pell.

Yever breed from the same tom more than two rears. It is letter to change every year, for there is nothing 
that will decrease the vitality of your stock more rapidly than elose inbreeding. In buying a trio or pen of turlieys, demand that the male is mot relater to the females. We have two flocks, each on a separate farm, and in filling the orders of our cnstomes we always select the tom from one floek and the hens from the other. We thereby start onr "ustomers on the right road to smeeess by furnishing them with good, vigorous stock that is not related.

Many breeders, in selling off their stock in the fall, clispose of their largest turkeysbecause they bring more money and keep the late hatched specimens to breed from, thinking that by spring they will be sufficiently old and large enough for breeders. This is a mistake. Ion cannot raise large, vigorous turkeys from small, late hatched birds. By all means keep your earliest hatched turlieys for the next year's breeders.

Some breeders adrocate mating an old tom with pullets, but I prefer mating the pullets with a good, young tom, as an old mate is sure to injure and probably kill some of them.

If you have unly a few turkeys by no nueans rard them, for they will dn much better when they are given the entire range of the furm. During the laying season

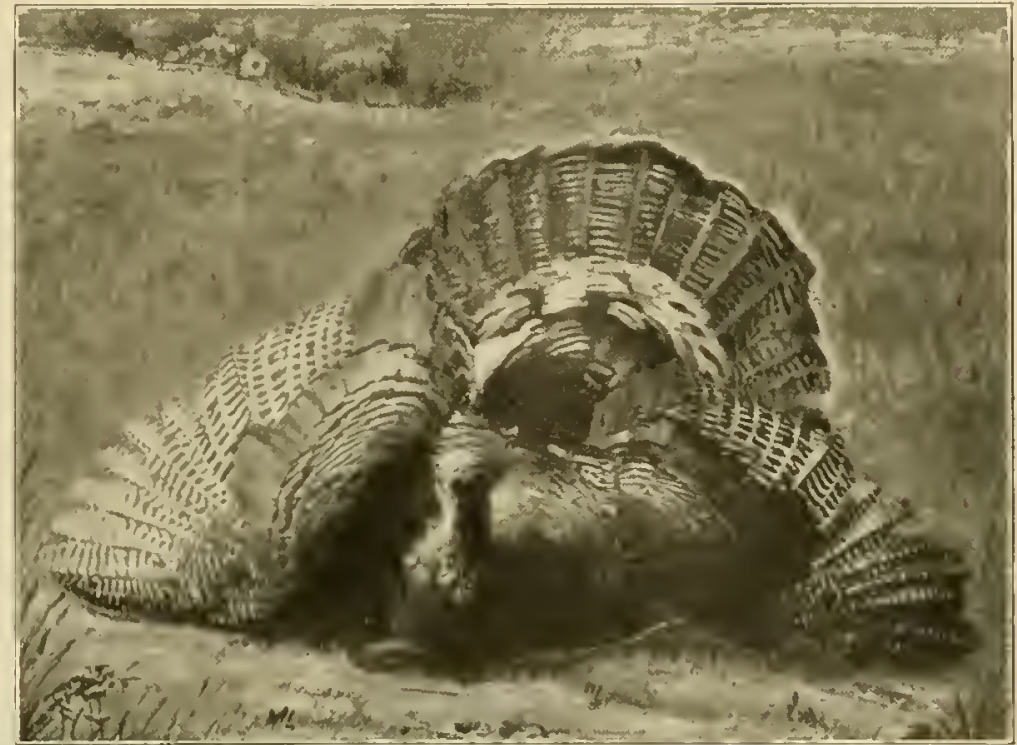

One of J. T. Thompson's Turkey Toms with Tail and Wings Spread to Show their Markings

it is sometimes clificult to find theil nests when they have so much range. but if you will pen four hens until the aftermoon, they will go straight to their nests.

\title{
THE FARMER'S BEST FRIEND
}

\author{
The Mammoth Bronze Turkey So Proclaimed by One Who Formerly Would Not Allow a Turkey on His Farm-Turkeys as Pest \\ Destroyers-Selection of Breeders-Hatching and Raising Poults
}

\section{MIS. J. M. RANDOLPH}

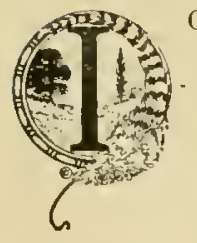

CONSIDEl the most important thing in turkey ralising is groud, healthy hreeting stuck. In selecting a tom I look for good marking's on wings and tail, a long body, large leegs ant feet and as the standarl requires heavy weight. as large a birl as I can get that meets these requirements, although in my own judgment it thiry-two puund tom is large enough. I think most ald turkey breeders will agree with me that there was a great mistake made in demanding such heary weight toms. As I believe the poults get size from the hens and markings from the tom, I select the heps with regard to size first, but wilu markings as good as I can get on large hens.

About the middle of February or when the hens begin to call-a sound familia to all turkey breeders-and show signs of mating, I remove them to a roung orehard enclosed with poultry netting, and clip the right wing of each hen, int I never clip the tom's wing, as lie will not give trouble ly trying to fly out as a hen will do if her wing is uot clipped.

In this yard they have plenty of range, blue grass and clover and $I$ never let them ont until the breeding season is over. I believe erery breeder should have an enclosed rard or park for turkeys. MInch as I shonld dislike to give up raising turkeys, I would do so hefore I wonk go back to the oll way of letting them have the run of the farm. I canot forget long, weary, oftimes fruitless searches I have had trying to find their nests, only, perhaps, to have them move again in a few days.
We have a great many osage orange hedges in this part of the country and these hergess seem to be a farorite place for tmikeys to hide their nests. I have had them follow the hedge more than a mik ant then make their nests. Iheing in an enelosnre nut only ensures your getting all their eggs, but they ean be gathered often and thus avoid having then chill during the early spring months.

\section{TURKEY NESTS}

Turlieys in this locality usually begin to lay the latter part of March. Ifter confining them to the park I take some evergreen houghs and lean them against the ponltry netting which adjoins a herlge fence un one side of the park, thus making a sechuded place for them to nest. I do not leave a very large opening, but let them ercep in, anc they think they are hiding their nests. ['sually I keep about twenty-two heus and most of them will lay their first clutch of eggs in two of these nests, but later on when the grass grows knee high they will steal their nests and sometimes elude me for sereral days or a week, but by that time it is warm cnough so that the eggs will not ehill.

\section{IIATCHINI TIIE POULTS}

Athough turkey hens seem to be expressly designed to take care of theil oflspring and know how to do this part of their work to perfection, I have not found them to be as good sitter's as domestic hens. For several years I have not waited nntil I had a turkey want to sit, but as sonn as I have enongh eggs for several sittings I place 
them under domestic hens. About two weeks before they are due to hatch 1 put some hen egrs under a broody turkey hen and when the turkey eggs begin to hateh I placed one or two eggs under the turkey and she would own them without any trouble.

Last spring I kept breaking my turkey hens from sitting in order to keep them laying and so at one time some turkeys were to hatch in a few days and there was no turkey mother for them. About that time I had another turkey want to sit, so 1 gave her, withunt moving her from the nest, two or three small Barred Rock chickens to see if she would own them, placing them under her jnst at dusk. Next moming she was horering them and was rery prond of her suldenly aequired family. so the next night I mored her to a building and gave her eighteen little turkeys, of which she seemed just as prond as if she had sat four weeks. This was a new idea to me, but 1 thought why not use that plan altogether and thus keep the turkey hens laying. 1 did so the balance of the season with eiglat or nine turkeys, giving them moods when they had sat only a few days and in some instances only over niglit. Iust one hen out of this number refused to own ant care for lier bruod, the otlyers acted as if they had sat the alloted time. 1 shall tra" it again this seasoni and $I$ feel confident that it will work all right.

The best suceess $I$ ever lad in raising poults was in a small lot witl very short grass and a very large coop or small building in which they could roost. They were kept sbut in on rainy days and in the mornings until the dew dried off, nntil they were four to five weeks old. Then they were turned out to range, being driven back to their eoops at night. For the first few weeks I find clabber

cheese and green onion tops, pinhead oatmeal and millet seed to be good food for them. A little bone meal and small sharp grit also is put in their food once a day. I find sand and old plaster is good for them and a load of sand is hauled and plaeed where they can run to it. No one has any idea what a lot of sand young poults will eat until he nndertakes to carry it to them as I did one spring.

At this season we always have plenty of milk and so I give them new milk every lay, first boiling it to prevent bowel trouble. When the little poults are just one week old I pull ont all the flight feather's in their wings. $B y$ the time they grow out again the little birds have more strength to stand the strain of growing them. Since following this plan I have har mueli better success in raising them.

1 also go over them once a week and treat them for liee, rubbing a very little lard on top of the head, in the quill feathers on the wing and just below the vent. I lost a great many turkeys hefore I knew that when lice and mites were around the last named place they were most fatal. Remember I said a very little lard, for smearing the body with grease is sure death, as I learned by sad experience. Occasionally I use some good insect powdel instead of lard.

Ifter they "shont the red" and can be driven to the pastures and meadows it is surprising to see how they will thrive and grow with only a little food to induce them to come home at uight. A more beautiful sight in poultrylom than a large drove of Mammoth Bronze turkeys with theix bronze plumage glistening in the sunlight, l eannot imagine.

\section{TLRKLYS AS PEST DESTEOYER}

Fears ago I used to raise the old fashioned mixed turkeys, but iny husband grumbled so about what they destroyed that 1 gave up raising them when he said if I would dn so he would give me his note to pay me as much each fall as a drove of turkeys would bring. So I did not try to raise any for several years. Then a neiglibor wanted to exchange some turkey eggs for some purebred Buff Cochin eggs and I made the excliange to accommodate her, besides I wished to raise a few to liave for Thanksgiving and Cliristmas. I raised five very nice ones and killed two of them, but decided I could not manage any longer without turkeys and so kept a tom and two pullets to raise from the next year. The next fall I sold them all and bought six pure-bred turkey hens and a fine tom and rent at it in good earnest so that the next year 1 had a fine drove.

Near the house we had forty acres in elover and the grasshoppers were so plentiful that the turkeys seldom went more than half way aeross the field unti] they had all they wanted. The result was that when the clover was eut for seed it was found that only the part where the turkeys had ranged was of any account. The grasshoppers had rnined the other part. 'That convinced $\mathrm{my}$ ' husband that turkeys were a good thing to have around, in grasshopler seasun at least. It was wonderful low those turkeys grew.

This season we had our clovel for seed on another part of the farm a mile or more from the honse, and I had a drove of over one hundred turkeys. The grasshoppers ate up all the clover seed. Wvery day my husband would say, "I do wish those turkeys could get to that clover field, for the grasshoppers are ruining it, and $I$ slall have to buy my clover seed." And so he did and he lad to pay a good price fol it. He said that after this experience he woulc? try to have his clover for seed near the house. A prominent turkey breeder told me afterwards that I could have trained the turkeys to go to the field if I had begun to do it when they were first turned out to range. In a case of this lind again, I am going to try jt.

I hope this article may help some farmer's wife, whose husband, like mine did, does not think turkeys pay, and who, like myself, has need of some loose ehange. Jerhaps the husband, like mine, will become convinced that turkess are the farmer's bos's friend. 


\section{SUCCESS WITH TURKEYS}

Time and Method of Makiog a Start-Housing and Feeding Breeders-Nests and Food of Sittiog Turkey, - Care of Poults-LiceFattening Stock for Market-Preparing for the Show Room-Diseases of Turkeys

\section{MRS. BETTIE GLOVEIR MACIEY}

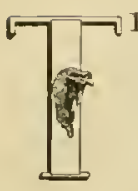

RULY there is more interest talien today in poultry culture than erer before in the his. tory of the American people. There seems to be an awakening to the fact, long proclaimes by a few, that there is money in poultry. The question is seldom asked now, "Does poultry pay?" The form has changed and the question now is, "How can I manage my poultry to get the best returns?"

It seems to me that the poultry business, and especially turkey culture, is one belt which reaches around the globe. America is sending fine turkeys to foreign countries, and the west is furnishing the enst with her best turkeys. I have shipped turkeys and eggs from ocean to ocean, from Canada to Mexico. The turkey is one American bird that will thrive in any land, will grow on any soil, or in any climate, and is considered a luxury by ali, from the king on lis throne to the humblest laborer in his hut.

There are more specialty fanciers than erer before and in no department of poultry culture is there more interest taken than in the turkey department. Of the m any rarieties, the Bronze is the leading one now bred. It is hardy, easy to breed to Standard, has fine style and is a beauty in color. It is of quick growth and will attain immense weight if fed for flesh. The objection is urged that the Bronze is more roving in disposition than other breeds. This disposition to roam is not confined to the Bronze alone, and the roaming turkey is more bealthy than the one which hangs around the back door. Whether any other one will ever supersede the Bronze in popularity remains to be seen. Of one thing I feel assured, and that is that no breed now in existence will ever rival them. What may be produced by a cross we do not know.

While there is general admiration for the turley. and a desire to raise them, there seems to be, among those who hare nerer handled them, an impression that turkeys are very hard to raise, rery expensive to keep, and difficult to manage as to disposition, that is, that they are such a roving and wild nature it is almost impossible to keep them at home or tame them. This last impression has grown out of the first. For years it was the enstom, when turkeys hatched on the farm, to take them as far from the liouse as possible and put them in at place of security from vermin, and the only person who went near them were those taking them food. This was said to be the only way in which they could be raised, for if they were kept near the house they would be sure to become unhealthy and die. I well remember when I thought this true. Of course, turkeys thus raised became timic and ran away from every thing or person they saw. They were generally fed until six or.eight weeks old and then allowed to make their own liring. Naturally of a loring nature, they did not scek quarters near the house, and I have seen them fy to the highest trees whenerer they were approached. They would tear down shocks of corn, for how else were they to get their living? No one thought of feeding them.

\section{WILD TURKEYS IN VIRGINIA}

I do not agree with persons who think turkeys are hard to raise and keep healthy. But they cannot be raised in a haphazard manner. Follow nature as nearly as possible. and the poults will do better.

IVild turkeys abound in warm, woodland countries. In the pinelands of Virginia (my native state) wild turkeys grow in large flocks. This is a mo untainous region, rocky, abounding in springs of erystal water.

The pine trees are in all forests, and it is said that there is more or less of the properties of turpentine in the water. Even in rainy seasons the rocky hills are not very wet and there are such large, sheltering trees the hen turkey can protect her young in the hardest storms. The seasons are mild and the pine trees are said to be a prerentive of vermin. As turpentine is sure death to lice, I think it reasonable that the pine will prevent them. There are abundant seeds and wild food for the fowls, with plenty of insects and grit.

Following this lesson in nature (where the wild turkey thrices and large droves of tames ones are raised) I draw the conclusion that a hilly, rocky slope is a good locality; that turkeys must be kept dry, hare plenty of pure water and fresh air, and at the same time not be allowed to become chilled. Either they must have at place where there is plenty of grit or it must be supplied to them. I do not favor giving poults or chicks hot feed. It is not the natural way and we cannot improve on nature. I have snceeded in raising strong, vigorous, gentle turlieys.

That it is their mature to roam cannot be 
denied. lut this nay be greatly wercome by the treatment

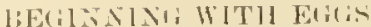

Frenuently 1 am asked which is eleaper 10 hegin h, eggs or stock. This question can be truthfully ered-Fogs and stock. Circumstances and surdings latgely deeide which is cheaper. It you have money buy a trio of turkeys: if not enough for a then a pair: but if you liave not money enough to the turlieys, buy a sitting of eggs. 1 have marle some very profitalle investments in egors.

I have been asked if turkey eggs will hatch after hreing shipped? I reply that where eugs are dightly paeked and fanly lambled there is mothing in the shipping to prevent a hateh. But there is a great deal in the hen under which they are set. From exactly the same lot of eggs set at the same time one hem will hatel serelal hours hefore the other and will hatch every egg, while the other hatch will be very poor. If you breali the eggs deeide whether it is the fault of the egg-an infertile egg will not rot, but will be as clear at the end of the hatch as when set. Turkey eggs are usually better fertilized than clicken eggs.

Follow these directions when setting shipper eggs: \$llow then to rest twenty-four hours after receiving them; longer will not luwt if kept in a cool, dry place; put them under a quiet hen in a quiet place and disturh her as little as possible. If the weather is hy sprinkle the egg's with warm (not hot) water a few days before they are due to luateh; be sure they are clean. If an egg should be broken the others must be washed with a clesu cloth in clear rain water; be sure there is no grease about it, as grease will prevent the eggs from latehing.

\section{BVGINNING WHTH STOCK}

I should adrise the begimer not to bug more than a trio. The mistake of amost all heginners is that they want to start with too many.

When writing for breeding stock state just what line of business you are in. Do rou wish to sell rour stock nu the narket ol as breerlers? Do you wish to raise exhibition birds or simply guod pume birds? Mnch of the mpleasantness between eustomers and arlvertisers would be obviated if eaeh inquirer woull make lis wants clear.

I think from the 25 th of Novembel to the first of February the best time to buy breeding stock. The sooner it is purchased after the first of December. the better, for at that time fanciers have plenty of good liods, while later you may have to take wlut fon can wet. Turkeys always pay, and while it may seem expensive to pay for a tom to ehange blood, it will pay in the vigor of the young turlieys next year.

Do not hunt for the elueapest, but try for the best. rhis is not always the heariest in woight. but the best molied and the best in quality. lum out for healthy. vigorous stoek. Do not wait until the weather is too (old tu have the birls slipped without getting the roup. Fun may think this strange advice when d tell you my inlkeys roost in trees all winter, hut I liave noticed that if you take a tmrey that has been used to the cold and jut it into a wam place aml tlen expose it to the colll it is liable to talie eold. This is what is done when turlieys are shipped in bitter cold wather. They are put imto warm cars and exposer to tle eold after being taken out and changed into a new home. ling your lreeding stoek early and tum it out and let. it get

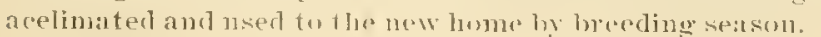

The most inportant part of turkey culture is to start will strung loceding stoek. I will not bleed from afowl of any kint that is delicate. If I lave weakly chicks or poults hatched $I$ am always glad when they die. Tet it is true that a chicken or turkey may take cold and have a sore eye or head for a short time and not he materially injured as a breeder. But when the disease becomes rery bad or cluonic, better kill the bird, for the progeny from a bird with a chronie risease will mever be of any aceount.

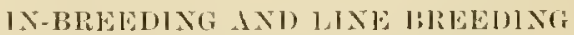

In selecting or buying lreeding stock. do not buy inbred turkeys. If you do you will lose by it. lossibly you may get hetter markings. but can you afford to saerifice the rigor of your flock for these?

I have been asked if I think it will do to breed from the same tom two years. The question, I presume, has reference 10 using a tom with his pullets. There may be cilcumstances where this could be rone to adrantage. In orker to secure certain joints it might be done, yet I think not without loss in the number of turkers raised. Demand, when ordering a trio of turkeys, that the breeder send male and female not related.

I adrocate line breeding and plactice it. But this may be done very easily without close inbreeding. I do it by mating on different farms every year. By looking up every sale and the valu from whieh the stock was taken, I aroid selling related stock. If a pen or trio is wrlered. the tom is taken from one yard and the hens from another. 'lhese are booked, and if the same customer orders again he gets new blood. To introduce new hlond, I luy eggs and nse the toms in one yard, the pullets in another. thus keeping my own line, but introineing new blook. If necessary, 1 import a tom at the ineediug seasun.

One who has common turkers would like to knuw whether it would he best to grade them up or stat with 1holounhreds. I think this is simply a matter of what you wish fu do with them. If only for market, the eross with a full Bronze tom will increase the size and beanty as riell as the rigor of your flock. But why not get the best and sell you toms as breeders to your neighbors? If you have the full blood aud are the first in grour neighborhool to get them, you can more than leplace the cost in the excess of the price over maket turlieys.

Imothel" asks, "How can I get largel turkeys? I have the lironze, but they do not get as large as some I ste adrelised."

Very often those advertised are never seen except in the adverticement. Int it is a fact that the size of turkeys nay be inereased by breeding from not only good individual birds. but from birds of good stoek. The greatest reason for production of smaller turkeys is in lise breding. To save the mice of a tom, a breeder decides to use one from his own flock, year after year. I to not hnow that using the same tom two years would cause the tmokes to degenerate in size. but the labit of inbreceling is injurious.

Igain and again comes the ruestion, "Do you prefer "in old tom or a young tom?" 1 can truly say, yes and ur. 11 all depends (n) the conditions. 1 let the purchasers hare theil choice, but I always give to customers preferring foung toms those which were bred from cither rearling toms or fearling hens, and often both. Where young touns are bred with yealling hens or pullets of harge bone and large ancestors. I see no difference in the size of the young. Still in my own breeding yards l use the old toms, for meople want eggs from the largest stoek to be fommel. 
VIGR, SIZE ANU FANCY POITS

Siveral have written asking which I think is the urst important point to comsider in breeding stock. My reply is, first vigor, then size, and then faney points. The reason I ennsirler strong, vigorous bircis the first pwint to be looked after is patent. If the parent stoek is not strong, the roung will not be so. Mind, I lo not say weight, but size. Turkeys that are not large framed birds may weigh very heary, especially young stock, but after the are fully: matured the bittle boned birds will not weigh so well.

Why do I say I eonsider size first? Simply because the stanciard requires weight and euts laarler for lack of weight than for anything else, and if we have to be groverned by the Standard we must come to consider size in breeling stock. If yon were to ask my personal preference, I might give a diflerent repir. The faneier must eonsider size in order to win in the show room, and then the turkeys are "eut all to piees" on weight which they lose in shipping. Igain, the faneier must consider size lrecause ten eustomers require large turkeys where me requires faney joints. Jut the fanejer minst combine the size and fancy points and this takes study in mating. It is not the rule that the largest turkeys in the fluek seore the highest, be they ever so well bret.

I will never believe that the demand for immense reights required by the Standard and turkey raisers is wise. I have lost the heariest turieys I ever owned simply from being over fat, and I do not feed very mueh for flesh, either. It is not musual for me to lose sales because I camont quote as heary weights as are demanterl, yet $I$ have as large turkeys as any fancier. I know orer-fat stoek is not goorl for breeding purposes, and so does every one who has given the subjeet any [alceful attention, yet a turkey must weigh so many grounds regardless of consequenees. If the would-be jurehaser would be satisfied with Standard weights then there would be some reason in the demands, but I luave often reeeived inquiries in November for fonng toms weighing from thirty pounds up to sixty, "sixty preferred." Now ererybody witl eommon sense knows, or shonld be tanght, that in this climate it is almost inpossible to make a young tom weigh thirty pounds in Norember or eren Deeember, and that to do so is an injury to breeding qualities. From January to Mareh young toms may weigh from twenty-eight to thirty-two pounds without any special effort at fattening them. I prefer a pullet from sixteen to eighteen pounds rather than one heavier, and $I$ know that $I$ voice the sentiments of some of the hest faneiers in the Uniterl States. The orer large hen does not lay so many eggs, nor are those she does lay so fertile.

It will not be many years before this demand for exeessive weights will be greatly modified. Market poultrymen say our Bronze turkeys are too large for their trade, and the market poultrymen must eontrol the turkey trade. If we continue to increase the size of the lironze, some other breed will take its plaee, and when this happens the Bronze turkey fancier who has tried to exeel all others by breeding the heaviest weights will see this error.

I hope I will not be considered as adroeating small turkey-s, for I am not, and I could eall hnundreds to testify that I stand for large boned turkeys. The weights of mine as adults have not been excelled in the west. but what I do plead against is the demand for the pound of flesh, which is far easier to put on the slort leggerl, small lumed turliey, than on the tall, majestic fellow, that will, as a yearling. weigh from thirty-five to forty foutds. The extremely beary weights are fit only for the show room and the funeier's yard, while the medium sized bird is the better turley for all purposes. I do not like to breed from exeessicely large turkeys, neither loes any other fancier, and yet the fancier has ereated the demand for these birds by advertising excessive weights to catch tracle, and the farmer lias eaught the spirit, and withont deally lknowing what is best, demants what he sees adrertised.

If I were a farmer raising market poultry 1 would want turkey pullets weighing from fifteen to serenteen pounds, good large-boned birds, not fat, and young toms weighing from twenty-four to trenty-eight ponnds, or yearlings from thirty to thirty-five. I would hateh my turkers early and in the fall they would be as good market turkeys as amyboly would want. I would keep the pure lironze turkeys, for nothing has ever equalled them. I would not do as some have done-inbreed until I derreased hoth vigor and size of my birds, nor would I sare the late small, runty turkeys to breed from. I wonll sare nice pullets and yearling hens and buy a tom from some fancier every year; or if I were short of money I miglit keep one two years, though I prefer changing stock every year. One tom is sufficient for iwelse hens, and more may be used with perfect safety. 1 wonld keep more hens than most farmers wives do, and instead of breaking them up from sitting, I wonld let then sit on their own eggs, or if preferred. I would set the eggs part under the domestic hen, giving all the young to the turkey hen, and if I did not eare to keep over so many hens I would sell the surplus after they lad laid the early eggs. I raise late turkeys, but if 1 were not a poultry fancier, and were raising market pon]try, I should not raise late turkeys; early ones are mull more profitable, they are mueh hardier during the snmmer, and are not so apt to be affeeted with the disease which takes off hundreds of young turkeys in the fall.

The farmer should learn that he needs good, strong, large-boned, vigorous breeding stoek, sneh as wil] take on flesh when he wishes to market them. Nobody wants i poor turkey to eat and if the ten-pound one is fat and brings more by the ponnd than the twenty pound one it still pays to have the twenty-pound one. but when the marketman say's he ean searcely use the forty-pound ones at any price beeause only hotels and large restaurants want them, the farmer has no need for fortypounrl young turkeys, as some demand.

\section{TREEDING FANCY TLRKEYS}

As to shape of tom and hens to breed from-I select large head and feet, long body, long neck, held well.up, and a broad back and breast, with long shanks. A short turkey will fatten earlier and look larger when not fully matured than the rangy one, bnt the latter will make the weight at matnrity much heavier, and will produce larger turkeys. 1 select hens the same way, yet if they are specially well marked and good in weight I would not diseard them if not quite as tall as I like them to be when pullets. I am sometimes disappointed in pullets, but cannot remember that $I$ ever have been in a tom-pullets sometimes are no larger at two than at one year old. They often stop growing at one year, while a tom never does. Other pnllets grow until they are two and three years old.

Ny method of mating is simply this: Select the very hest tom nossible, and in females do not diseard a rery fine marked one beeause it is not quite as large as desired. By this I do not mean that I breed from small 


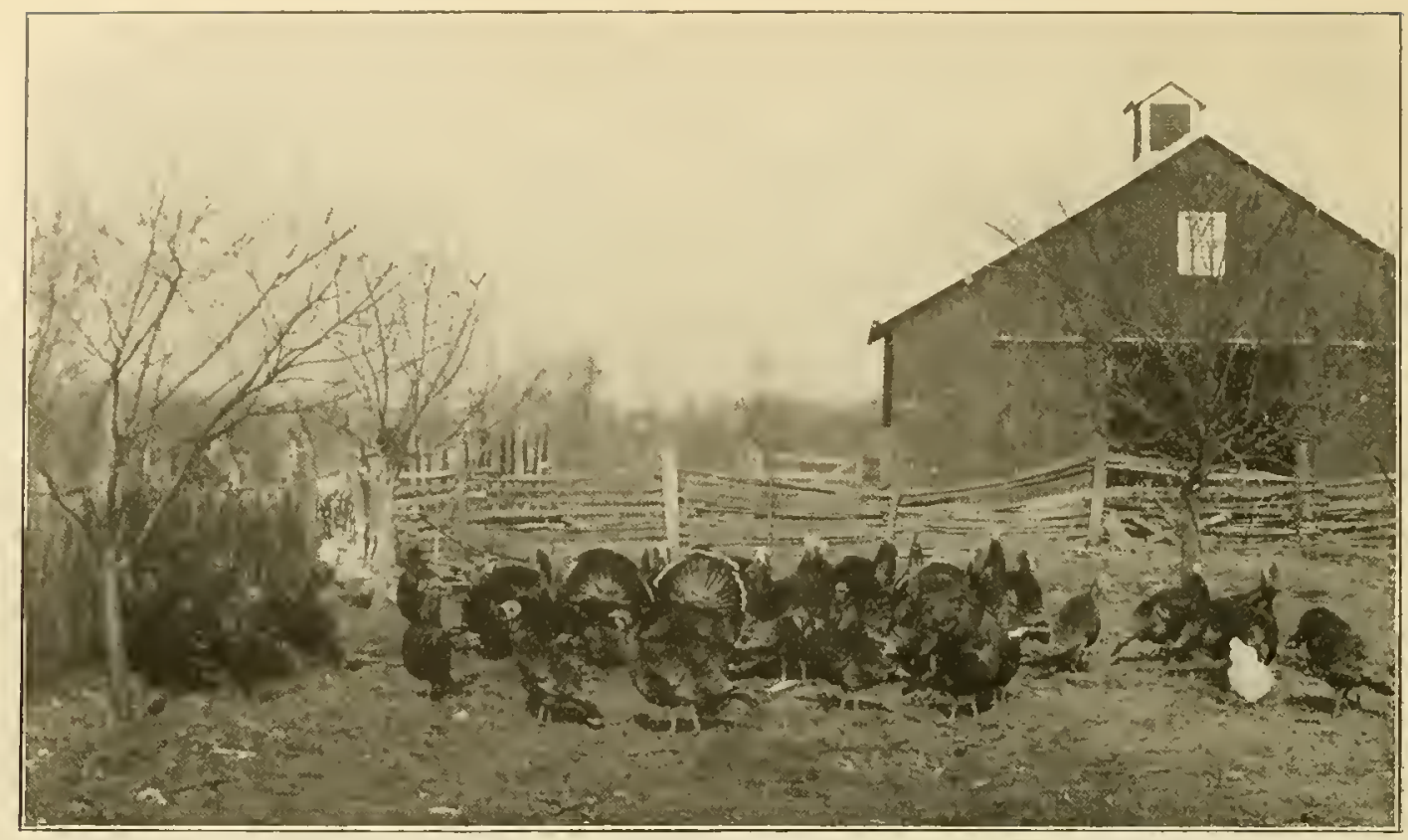

Some of the Fine Ones Raised on a Missonri Farm

A Flock of Turkeys belonging to Miss Addie Brown

boned females. There are some larger than others in all flocks of the same age, and I should not advise the use in the breeding pen of an undersized female, or a runt. Nor should I discard from my breeding yard an extra large female because she is not quite up in fancy points for the reason that the tom will overcome to some extent the defects. The well marked female will produce large stock from the mating with a large tom, and the one not so well marked will produce evenly marked young from the mating with a well marked tom. Yet these must be exceptional cases, for it will not do for a fancier to bave many females in his breeding yard that are not well marked and not very large. By undersized, we mean pullets, for if at two years old a hen is not of average size I should discard her unless therc were some special point I wanted to impress on my flock. I think young turkeys get size from the matermal side, even more than from the paternal. Never should a fancier use a late, small-boned tom, or a poorly marked one. As a rule toms get very thin in summer if mated with hens, and they do not eat a great deal until cold weather. I have known a tom to weigh twenty-six pounds in Norember and thirty-five by January. Turkeys will gain two pounds a week in cold weather, unless there is snow on the ground, then they will stay on the roost and will not eat.

I once had a red legged turkey pullet. She was not large when young, but her legs were almost too deeply colored to be called pink. I bred from her as long as she lived, or, I should say, until she was stolen. I could tell the turkeys from her eggs. They were a good size and invariably bad pink legs when young, though not as deeply colored as were hers. From this hen I got that line of breeding which gives in some of my vards pink legs in young stock. I can tell it wherever I find it. But this is the only female I ever kept that was undersize after she was a pullet. The rule is that the shanks are dark when young. Some of the best hens in size lave dark shanks always, while others get very bright pinkI prefer the pink legs, other things being equal. But I am candid when I say that I make size and not weight the first consideration in breeding stock.

Never breed from a turkey with a natural deformity. 1 once bought a sitting of eggs from one of the foremost lanciers I lnow. The only pullet raised had a crooked toe, but she was so fine I felt I could breed from her. Every year there would be a lot of turkeys. with crooked toes, and these were the very best otherwise. It took several years to get entirely rid of crooked toes.

While there are fewer culls among turkeys than there are among chickens, it is also true that under the present Standard some of the very best breeding birds are not first-class exhibition turkeys. For instance, all turkey raisers know that there is a tendency to brown edging on tail coverts in some specimens, and it is a notable fact that these specimens are usually very strong in wing barring and that they are decidedly larger boned than those which possess the Standard gray and white edging. Now such a bird cannot be sold for cxhibition, but if one is raising turkeys for market and selling toms to other market breeders, what better breeder would he want than this same brown tailed turkey, for as the market poultryman pays for pounds, it is the tom with size that one raising for market must get. Again, one may be poor in wing for exhibition and fine as a breeder. Yet I am sure that at least ninety per cent of the best bred Bronze turkeys can be put on exhibition when fully up in weight, and whether they win a prize or not they do credit to the owner. The main thing in breeding is to select bealthy, vigorous breeding stock of good size and shape, with the rery best markings possible. Don't expect perfection, but try to attain as near it as possible. Patience, perseverance and knowledge will bring success.

\section{CARE OF BREEUING STOCF-EGGS}

When once you have your stock, be sure that you get your turkey eggs. To do this I keep my turkeys penned. $I$ wonld prefer letting turkeys run at large if I could do so with much conrenience to myself. But to follow 
from twenty-five to thirty turkeys to tlieir nests is too great an undertaking for me, and $I$ keep them in a large pen until after they have laid. . Each afternoon about 4 o'clock I turn them out in an orchard of blue grass. After a few days they will come to the gate and call to get out. If I forget, they do not; but they always go back to the pen to roost. I find grass very essential both to the fertility of the eggs and to increase the number, and also to keep the turkeys healthy. If I were so sitnated that I could not let them out to eat grass, I would feed wheat bran with flowers of sulphur in it every other day in small quantities. There mnst be sulphur to insure fertility, but the grass supplies it. Plenty of lime, gravel and grass, with wheat twice a day, is all turkeys need. If too closely confined turkeys will not thrire and I believe that the freer the range the more eggs the turkey will lay, but when they lay where you cannot find the nest and you lose both hen and eggs, as I liave often done, you will prefer to get the eggs they do lay in the pen.

My turkey house is sixteen feet long, eight leet wide and has two partitions, making three rooms in it. It is made of barn boarding sixteen inches wide. Two of these boards are put together at the bottom, but as they go up cracks are left so tliat the air can pass through; however, they are too close for animals to get through. It is one-half foot high in front and three feet in the back and is set out in the orchard where the poults will have a seven acre lange of their own. This turkey shed has proved a success, and my young turkeys hare seldom failed to come up at night. I think the large, airy roosting place provided has had something to do with their coming up, for in small roosting places I was always compelled to drive them in, while all I do now is to turn them into the pen and they go to roost themselves.

The fence is the best I have ever used. It is milde of straight farm fence wire, with stays and locks. The wires are only three inches apart at the bottom, and the distance apart is inereased as they get higher.

I do not like to cut the wings of large turkeys for they often get up in trees and when they fly down they hurt themselves. My show birds are often spoiled by cutting the wirgs. They do not always grow out in time for the show. I do not cut the wings of the toms because they will stay with the hens.

The natural instinct of the turkey is to roost high and in ordinary weather I think it is best for them to be out of doors. My experience is that the first turkey to get droopy is one roosting low in the same place night after night, uiless the droppings are either removed frequently or the impurities counteracted hy frequent applications of either air slaked or quick lime.

I an often asked if one living on a small place ean be successfu] with turkeys. If by small place is meant a town lot, certainly not. If an eight, ten or twenty acre place is meant, you may be sucessful with a limited number; and if you trespass on your neighbors and they allow it, you may be successful with a larger number. It is no longer a question whether turkeys ean be kept on small space sucessfully, for so many overworked women are penning the birds and so getting eggs with mneh less labor, proving that with proper care the stock will be just as rigorous. We do not claim they lay quite as many eggs, but we get more of them.

My experience has been equally divided between a farm and a small place for raising turkeys. I have lived seven years where my turkeys had unlimited range and seven years on an eight-acre place. I give the farm the preference after the turkey's are grown. Until they are six or seven weeks old they do as well on a small place, but from that time until they are grown the larger the range the better for the growth of the young turkeys, and yet the finest turkeys I have ever raised were raised on the small place; but this is not an argument in favor of it, for they could have been raised with much less labor and expense on a larger one.

\section{HOW MANY IIEXS TO A TOM?}

I make twelve hens the number for one tom, as a rule, but once I kept twenty hens with a tom that was two years old in May or June, and never had eggs hatch better. The question of how to manage when more than one tom is desired in the same yard, is a troublesome one. The most satisfactory way in which I have managed it is to let only one tom in the yard at a time. Let one stay in the yard several days, keeping the other where he cannot be seen or see the turkeys in the yard. Then change, putting the one in the yard in confinement and letting the other out. Some advocate changing toms every day where changing is practiced at all, but I prefer letting each tom stay in the yard several days at a time. Where more than twenty hens are kept, two toms should be used as above directed if all the hens are kejt in the same pen. After the hens begin laying one tom may be disposed of if so desired. After the first clutch of eggs is laid I find that all the hens ncver lay at the same time during the season. Some are sitting, some stop laying and begin again, and some earry turkeys, so that one tom is sufficient after the first fertilization. But it is always safe to hare the second one at command if one should die.

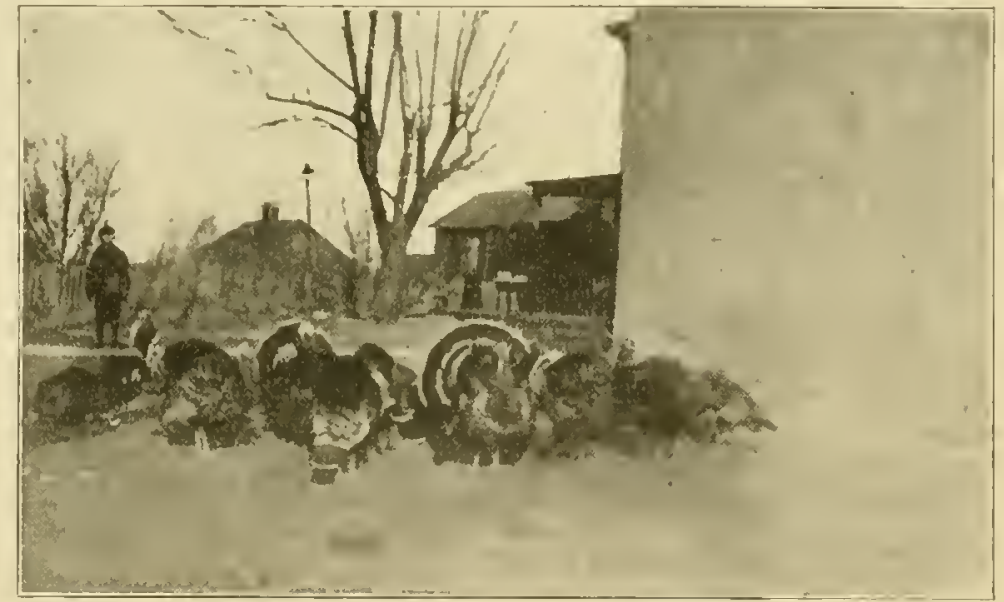

Getting Ready for Thankşivin ś

Notice the fine, white edging on the spread tail of the tom in the center of the group. Miss Addie Brown's Bronze Turkeys.

How long can a tom be used, or when is he too old for service? 1 do not know. I use them two years and have sold yearlings that were kejt three years. I never go to extremes in mating, that is, do not lieep too old or too young breeding stock. 


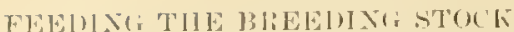

The brecting stock should mever he excessirely fat. ll stock raisers will anee with this assertin. Hlue thing mure prutuctire of soft sbelled amo infertile than over-fat hens and toms.

foed for the production of eggs has been 1 confess that I lave lost faith in hot ither chiekens or turkeys, and 1 never feed

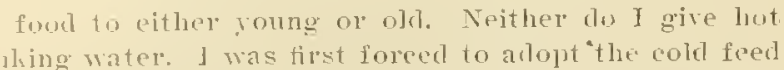
from sicliness. 1 could not get anyone 10 prepare a mash that dirl not make it slopys and 1 som learned whole glaim was fal mrove healthful than sloply food. If 1 un key have free range during laying seasun they eat litile llant you feal them. lief'p grit aud lime on in atumbance and siow whent for them. If it is laid pile they ofton leave it, but if seattered hrodeast they will pick all hay. Turlieys in thejr nolmal condifiom do not sit around during Jaying season; they are active and want to roam and pick as they go. I often seater the foud allel they go to ronst, as lhey are eaty risurs and begin picling before 1 have time to give hluen their bualsast. One thing yon may deprend upom and that is, to have turbeys biy well, and lay fertile eggs, they must lave an egg pumbing diet in some way. If they run at lage they will get this without any tromble to the owner, hut if they ale confinerl it most he given them. One rear I fed soaked oats with excedlent results, lut l would not give onts without soaking them. I mix shipstutt with them so they are not so wet. Wet food sours in the erop.

When should turkesis hegin to lay? The rule in my valls is, about the milale to the last of Mareh. J unce hat turlieys lay the last of February. My mother told me the "old-fishionerl turkejs"-by that she meant the common ones-laid earlier than the bronze. I think the climate may inflnence the habit of earlier or later laying. In a sumthem climate they lay earlier than in the northern.

1f you wall many egos. you must breed from yearling hens and pullets. Old hens do not Jay as many eggs, and extra large ones do nut lay as many eggs as smaller ones. A tall turkey will lay more eggs than a short one. Why? 1 do not Jnow. I think the last eggs laid by the hen before sitting sometimes produce punlts with less vitality than the whers.

Will the eggs from yearling turkey hens hatch as well as those from pullets? I think they will, the greatest Aanger of infertility lying in getting them orer-fat. They must be kept vigurous and healthy, but do not overfeed in orrler to get weight.

I am often asked low many eggs a turliey hen will lay. One of mine last year laid eighty, which is the largest number I ver coull vouch for. of course she was not allowed to sit.

one asks, "Do you think July too Jate to hatch turjeys?"

We have two toms which weighed in March twentyeight. frounds vithout having been fattened; they were hatelied July 3.

July and lugust hatehed turkeys of Jarge vigorous stock make good breeding birds the first year and exeellent ones the second year. but unless senree of breerling stock we usually farm out the late hatelues the first year, and put trem in our hreeding yaris the second. From these late hatches we give our turkey dinnexs during the winter:

1 disjensed with the barrels this year. having only one. I put straw in the loblows and covered them orer with brusli, allowing the turlieys to think they were stcaling their mests. Form twent-six luens 1 got seventeen egus per day, shwwing that antining the luens as I do does mot materially lesson the erg yield. When the egos are lemoned as they are labil, and 1 think it should be lome eqry lay, tither nest egr gourds, chima nest egres on leal eggs shumbl be put in the nest. Few turlieys will comfinue $10 \mathrm{lily}$ in a nest after all the eggs are jeinowed from it. 1 usually put three or four infertile egras in the unes as smom as 1 fimc a turliey has laid in it. This oflen saties much trouble, and yet with all my cal'e every year I lose hoth bens and eggs, for either a rnin washes out a Jole, a wind blows down the fenee or they fly wh after their wings grow out and steal nests.

\section{C.IRE WF SITTIXI IIEXS- HOAB-NESTS}

Ifow many eggs will a turliey hen lay before she sits? Sume lay more than others. but I never had a hen that lajd more than fifteen or sixteen eggs before she wanted to sit and I have many mure that lay only twelve than I have lhat lay fifteen. A turkey hen may easily be broken from sitting if she is taken in time, and by lhis means 1 often get twenty to thirty eggs before $I$ alluw a hen to sit. I hen will lay in ten days after she is stopped from sitting and some times in shorter time.

If you do not wish to make the nest as suggested above. then use not a flour or lime barrel, but a salt barrel. I tum the harrel down on the side, putting it moler a tree or in a shatdy plaee. The turkey will scratcli the nest up for the first fer days, but the barre] is a temptation she cammot resist and she will lay in it. 1 always put (lown several barrels. though $I$ find the turlieys all like to bay in the same une.

If the hen is thoroughly dusted with a good insect powler whem set, and the top outsige of the harel Jiglitly painted with a good lice killer, she will be free from lice when the hateh comes off. Be sure in nsing this that you do not put it where it will tonch the eggs or feathers of sitting hens. If you do you will in all jrobability fail to get a gumd Jatel.

$I$ set from serenteen to nineteen-never more. If the hen is latge and the nest wall made, mineteen eggs may be put under her safely.

Ismally I hav" a turkey and chmestic hen hatch the same time and give all the turkeys to the turkey hen. I luav mot been as successful with domestic as with turkey hens wutil this seison. [ know two other breeders who raise turkeys altogethe with domestic hens, and they are very successful incleed. Is a rule, however, the turkey hen is the bettel mother, especially after the puults atre seven wolss old, for othor hems wean them too early. I think a very good plan is to let both chicken and turliey hens have young turkeys the same age, and when the chicken hens wean those muler their elarge the turkeys will let them fol]ow them and are for them all.

Do not set your 4 urkys where there will be anything to disturb them. Whein they hateh lse eareful to handle them very gently. If 1 find 1 have one cross turkey about to hateh, anrl i have a wentle. kind one not dne to batch, I exchange the sogs and let the gentle turkey latch the broort. I find 10 prolong the period of incubation tmes the lofractory disposition and oflen a turkey that will he fussy at the enil of fonc weelss, will be gentle at the expination of five.

rew people, compalatively spabling, lnnow how to set a turkey ur clomestic hem, "1 how to eatch either a turlicy or elicken. When you lind yul turkey broody, let her alme mulil night. Have ymu nest prepared in some quiet place where sine will be mulistubed by other 
fowls. Nake the nest with eare. I like the gross nest better than allything else, hut as I to not have a bountiful supply of this I use wheat straw. I do not like lay uests at all. Malie then very much the shape, but not so deep, as a wash bowl. [f too deep the egg's will roll orer each other and either be boken or they will uot le kejt of an even temperature during incubation. Malie af full, thick nest, for four weeks" sitting will mash the straw down very much. ['ut two or three hen eggs, as they are not so valuable as turkey egge, in the nest. It night go to the hen rery quietly and put butlo hands vincler lowe. taking her firmly by the leg, close to the body and lift her straight up. Don't trag her out of the nest. Put her head under your an gontly, talking tu leer all the tine. Flace her $a$ the new nest rery gently and set a blind firmly in front of it. 'The next mornmg sou may peep in. It will be an exceptional ease if sle is unt sitting as well as she did on her old nest. I look at loer again about rousting time. If I fincl her restless I let her otf. If she is liept on the nest in this restless, nervous state, she will break the eggs and likely will not sit. at all. She will probably $1 \mathrm{ry}$ to get to her former lust, but as flark approahes she will go to the new me; 01 if she does mot allow her to go to the old une and remove hey as before. I have often hat to to this several times with whe hen. Is a rule, however, the secont time is plough. You may say that it is al great rlesl of trouble. I do not eall it trovble. It is work, and t learned very ealy in life that to he suecessful in anything requirerl patience and work.

After the hen has fully decilled to aeept the nest given lier then put the turkey eggs under her. So many preopie waste hy laste. What difierence will two, three or four days malie in the age of the poults? But what a calanity to lave a sitting of turkey eggs spoiled by a restless lien.

I usually give my turkeys the npportunity of getting off the nest every day. I find this mueh more satisfaetory than keeping them so long without allowing them the ehanee to get off. Often they do not come off for streral days amel I had one hen that mever eame off in four weelis except as I took her off the nest. I then ladd (1) put the blind up in front of the nest and foree her 10 stay off loug enough to eat. I thought that I eertainly wonld lave a good hateh from this hem, but $I$ had why ten pouks from seventeen fertile egrs. She had smothered the turkeys by sitting so close. 'Turker eggs hat (h) hetter than chielien eggs, but they require more moisture.

It the weather is wet I lo not moisten the eggs, but if dry I sprinkle them the last week. When the egg's have been setting until within three or fom days of the time to hateli, put them in clean, warn water-100 degrees is abont right, or if it goes to 104 it will not luurt. Ill the eggs which have live poults in them will move rely pereeptihly. Those which sink to the bottom have deacl puults, ant those which float without any jerky motion are spoiled or infertile. IIowerer, the infertile eggs usually sink.

\section{TIRKEY ETRS IN INCUATORS}

Will turliey eggs hateh in an incubator? They certain!y will. I mee told a lady that from fourteen turkey eggs in an incubator. I got fourteen turkeys. She in all scriousness replierl that "a heu would do as rrell as that." If yom expret more than rne turkey from an egg an ineulntor will likely disappoint yuu. I do not lat tely turkey eggs in an ineubator beeanse I ro not wish to raise the yumng in brooders; but if an egg gets brokeu
I put it in an inculator. Last season the finest young tmikey I had hatched wa from an egg with quite a large piece of shell broken ofi of the large end and I cut a piece of eitton eloth just a little larger than the lasle and made a thou piste, just touched llue edges of the rotton with it and placing it over the eavity, put the egg in an incubator and it hatched in due time. the reason I used cloth was-it is nearer the texture of the shell. Paper is mot purous enough. Flonr paste is better than gine: nse only just enough to make the eloth adhere to the arg. With a elean. damp cloth 1 wiper off all surplus paste after the eloth was put on the egg. This woulici mor have hatched under a hen, as she would have broken the rigg.

lsmally I do mot atre to have turkeys hatch until after the colsl suell in May. Lut it is all right earlier if the weatlee is warm. let if they come out any lime in May they will wet the weight for the December and January shms. This is one advantage southern breeders hate orer westem. Whe ship turkey eggs south as soon as the turlieys loegin to lay. When one las a large numher of early hateheal turlieys I would not artvise the raising of late mes unless they can be entipely separated from other fowis of every kind. Sut if for any reason you have failed 10 have early hatched ones, hateh them late. The! malie fine table fowls.

lears ago I bought a sitting of egges from a prominent turkey fancier. I was sorely disappointer when I openeri them as I had never seen such small turkey eggs. I made amother orler to anothel faucier and never saw larger eggs than I received. The turkeys hatcherl from the small egges grew to be largel at maturity, though of comrse they were not so large when hatched.

One tom from the small eggs rreighed forty-four jounds at two years old and one hen twenty-four. Those trum the large eggs never got so large, though they were fine turkeys. In spealing uf this to an old lady and my surprise at results, she replied: "I don't see why you should be surprised. Natule does not vary much, whether in lower animals, the feathered tribe or the human family. 111 depremls on the blood." I believe the old lady was right. I prefer medium sized eggs, both in turkeys and elickens. I find the very large eggs hateh linge young, but they are not generally as well formed and often are weak legged and while medium sized ones hateh smaller foung tliey seem more rigorons and grow meh faster. Of course there are eggs that are small to defurmity-so are llere those that are large to deformity. Often the last egr laid before a hen goes to sitting will be so small it will have nu yolk at all. It is also true that the largest egrgs are not always laid by the largest liens, thumgly as a rule pullets lay smaller eggs than hens.

Many do mut linow the difterence between an infertile and a rotien egg. A rotten egg is never elear and "tu infertile egg is always elear at hatching time and does not have an olieusive odor. Eggs may rot from age or because they are not suffieiently fertilized and the germ dies belore maturing, and they may rot under lens which sit well, but do not have suffieient body leat to hatch them. Again they may be set where there is too much dampness, which eauses them to rot.

We are often askerl if tanciers do not sell eggs too high. We think not, for several reasons. First, customers often write that from five dollars' worth of egors they sell ten clollars worth of turkeys and have a good breeding pen left. Seend, faneiers are at great expense to bold stock enougli to supply egg orders, and run much rish in holling orer so many turkeys whieh 
he sold in the spring. Third, the customers build their reputations on the fancier's work, and certainly this is worth something. You are not simply buying eggs from the fancier, hut you are bnying the experience of years.

\section{CARE OH POLLTS-IEEDINT-LICH}

I would by all means prefer a turkey hen to carry the turkeys. The natural mother is the turkey hen. She seems to understand turkey nature better than the domestic hen. There is only one advantage gained by letting the domestic hen carry the poults; they do not wander so far from home, though I think this is counteracted by the disposition of the domestic ben to wean them when they need a mother's care as much as when first hatched. And the turkey hen never begins to wander so far until the poults are as old as they are when domestic hens wean them. I find that it is the poults which lead the mothers away; they go and the mother follows.

It is a mistake to give a turkey so many poults; of conrse she may raise them all, but the chances are much better for her to raise all of twenty than they are for her to raise thirty to thirty-five.

When the poults hatch be carefnl in your management of hoth the young and the hen. I try to have the nest fastened very securely so that the little ones cannot get ont, for they will get out of the nest and get chilled. Sometimes they latch a day ahead of time. I look in the nest the night of the twenty-serenth day and if there are any poults I take out the shells and if there are only three or four poults I leave them in the uest; if there are six or eight 1 take them out and keep them in a flannel cloth in a basket in the house, as so many left in the nest will cause the hen to sit off the eggs in a hovering position. If you take out only a very few they may get chilled. In the morning I go again and remove the dry poults and egg shells. By night she will be done hatching, but as some of the poults are weak I just put a few of them in the nest with her so she will not refuse to take them in the morning. In the morning $I$ have a quiet place reacly for her and I give them to her.

I think I lave at last gotten the ideal turkey coop. I found that the large coops with divisions in them were all right when the poults were rery small, but when from five weeks old to the time of going on roosts, they were too crowded in the division coops. I now have coops four feet square, with height of back four feet and height of front five feet. The sides are of screen wire, the back and front of plank, with a tight board roof. These are set in the orchard and are moved to a fresh grass plot every week when the ponlts are rery small, and every two or three days as they grow older. I have hoard roosts put in them as the poults want to go on roosts, and let them roost in these coops until all danger of drowning from heary rains is past. Turkeys must have plenty of air. They cannot stand confinement in close coops. These I now have are, so far as air is concerned, as good as if they sat out, and ther are safe from "varmints."

\section{FELD FOR POLLTS}

I have tried almost every plan I ever heard of and have finally settled down into one way of feeding. I beliere the nearer we imitate natnre the more successful we will be in poultry cultnre. I feed very little of anything to poults, especially very little bread.

I never feed my poults until they are from twentyfour to thirty-six hours old. Then I put them out in a grass pasture in a large, roomy coop, with grass runs attached. The first feed I give is milk curd with onion tops and tongue or pepper grass eut very fine, seasoned with black pepper. I give this morning, noon and night. Is they grow older I add other things to the food Table scraps are splendid for them. If I have infertile incubator eggs later, experience teaches me the raw egg isroken in the food from the first is good food, better than hard boiled eggs. I never use a fresh egg, simply becanse $I$ do not consider it at all necessary. I give milk instead of drinking water when it is plentiful. Milk has all the elements of food for the human or poultry race, hence I feed all I can spare to my poultry. Heat the milk, but do not boil.

I keep grit constantly before them. Wheat is one of the finest of foods for young turkeys, but it must be pure wheat, not cheat. Cracked corn is splendid when they are older. My rule has been to mix grains of wheat in the food from the first. so that when they are old enough to change from curd to grain it will not be hard to change foods.

I have used corn chops and ship stuff, equal parts. jut in the store and made very hot, then pour cold water over it and have found it very good. Still I believe I must have some wheat mixed in. Lime should be kept where they can get it at will, but it should be lime that has been slaked a long time. I believe fresh lime will lilli old and young turlieys.

As soon as they ale old enough to eat whole corn give it to them. for nothing makes them grow faster and gets them ready for the show room quicker.

It is very hard to get a young turkey to change its luabits of eating. If you commence feeding them in a plate it is hard to change to a pan or on the ground. The same liolds true of the diet. Whatever they learn to eat at first is what they want until they are grown. If the food conid be scattered and the turkeys allowed to lum for it, it would be much better for them.

The great trouble is not so much what to feed as what not to feed. Turlieys shonld not be overfed; this is the mistake made by so many amateurs. They think the more they feed the faster the little ones will grow. If it were possible to raise the turkeys and keep them from the clutches of "varmints" (there is nothing more expensive), the rery best way to raise them would be to give them to the hen and let her take care of them during the day and feed them just a little in the evening to keep them gentle and make them come home.

Do not allow your poults to become wild. If when you gro to feed them you will call them and talk to them, they will learn to come to Jou anywhere. My turkeys and my Leghorns are gentle, and will come to me whenever they hear my voice. If possible, let none bnt a gentle hen carry young turkeys. A mild mother makes mild turkeys. "Like mother, like daughter" is certainly true of turkeys.

I find that cracked wheat put into the stove and browned as we used to brown our coffee, with jnst enough cold water or sweet milk poured orer it when taken out of the oven to dampen it thoroughly, makes a very fine food for poults. I grind the wheat in a coffee mill. This I mix with milk curd and fine chopped onions.

Until I have fully tested it I will not give my opinion in favor of doubtful foods, and I confess I was afraid to give the corn chops used as chicken food, though I believed it would be good if fed judiciously. One season I began when the poults were four weeks old giving corn chops at night. I just dampened with cold water and I never saw turlieys tlirive better in my life. Be snre you do not get that ground with the cob. It is not fit to feed either to chickens or poults. 
I used blood meal one season and liked it very much. I think in order to give it I shall feed soft food at least once per week during the year. I am sure that for growing poults and chicks it is very fine. It seems to be of great benefit to them while feathering.

Iftcr turkeys are ten weeks old all that is necessary on a large grain farm is to see that they are protected at night. They will glean their own living from the fields, and while the "gude man" may complain, yet if he will only watch them closely he will be convinced they are a benefit to his crop instead of an injury. Last vear the turkeys saved the corn, but the chinch-bug killed the turkeys in many localities. Turn a flock of young turkeys when from two or three months old or even five or six weeks old in your potatoes and cabbage; they will not hurt them, but will keep them free from bugs. Yet there is one kind of potato bug they seldom pick; if they.do it likls them. But the cabbage worm does them no harm and they do not when young hurt the cabhage. They clean the corn of grasshoppers and glean after harvest in the wheat fields what everything else has overlooked.

Poults will not bear handling. Mine are rery gentle and eat out of my liands, still I never handle them in my hands if I can avoid it. It will not do to try to raise young turkeys in the same yard with other fowls. They are so tender that chickens run over them. One snap flom the bill of a domestic hen will kill a rery young turkey.

What do you do witl your little turkeys during a cold or wet spell?

We shut them up in the house they roost in and let tliem stay there if it is very wet or cold, but if not very cold we let them out on our front lawn. The grass is nerer rery high, and as a rule the lien will hover them and keep them better than in a crowded spot. Keep little turkeys dry and warm, for if they once get wet or chilled they seldom recover. Some hens are more restless than others. If possible to avoid it never let a restlcss hen foster turkeys; howerer, one good feature about them is that they are generally of that spiteful class that will protect their little ones.

It does not hurt them to turn them out soon after a hard rain if the sun comes out warm and bright, but if it is cold and cloudy they will die from exposure and being chilled.

But if at any time they should be canght out and some seen dead when found, make a fire and warm and rub them well. Often $I$ have brought both chicks and poults to life that seemed perfectly dead. Feep them near the fire, but do not let them get too hot, until they are entirely dry. Gire each of them a cracked grain of black, or a seed of red pepper. This warms them and stimulates them.

Do uot put the young turkeys out near ant holes, as the ants if swallowed sting the crop and kill the fowl, and often the ants sting the poults on the body and kill them.

Poults are greatly benefitted by having their wings and tails cut. I find they get about so much better, and if a rain comes up they do not seem to get as wet, or if they do they dry so much faster. It takes so much strength to support the long wing and tail feathers that if they are kept short until the turkeys are two months old they will be much stronger than if the wings and tail are left to grow without cutting. I cut the flight feathers about half, and the tail about the same.

There is very little expense attached to rearing tur- keys, but as a rule there is a great deal of work until they are ten weeks old.

Summing up the requisites for success in raising poults may be done in the following simple words:

First, have vigorous parent stock, not orer fat. 'Take care that the poults are not chilled the first two or three weeks of their lives. Be careful not to orerfeed the poults. They require very little food for three weeks; after that time feed all they will eat three times a day until they are realy for market. If, however, you hare grain fields for range they will eat rery little of your food after they are six weeks old until late in the season. Be sure to keep them free from vermin. It is almost impossible to cure a droopy poult. If one is droopy, try to find the cause and remove it before the entire flock becomes afflicted. Young turkeys will do better with no luman attention than with too much.

\section{FllIITINT LICE ON POULTS AND ADUITS}

I find that whitewasling the house in which my fowls are kept and keeping it thoroughly clean has been a sure preventative of vermin on my young turkeys.

Use tobacco stems and tobacco dust as follows: Smoke the roosting places with the stems and sprinkle the floors with the dust. If the coop in which the hen is put with the poults is whitewashed inside and outside before she is put in, she will not become lousy.

I swcpt the roosting coop every day and dusted it once a week with air-slaked lime. Lime must be dusted sparingly, for if too much is used it will make the feet sore.

When the nest has been well prepared and dusted there are seldom any lice, on the little ones when hatched. But I dust the hen with Persian insect powder when I take her from the nest, being very careful to shake the dust well out so that it will not get into the eyes of the little ones, as it may make them blind.

The turkey lonse is about the color of the poult and is very hard to find by one not experienced in the art of hunting them. They are between the quill (flight) feathers and are often in solid linots, and at first glance will not be liscovered, as they do not move until disturbed. A little clear lard oil will kill them, but it must be rery carefully used. I prefer using it at night. Dnst the hen well with insect powder when you turn her ont in the morning. I know most persons say at night, but I have found the powder gets into the eyes of the poults.

One thing is certain and that is that ponlts must be kept free from lice and mites. Then it is equally certain that if not careful in the use of remedies for these the poults may be killed. A little pure lard on the head, around rent, and on the wings, where the flight feathers come ont, may be used to advantage, but too much is absolutely fatal. I would not advise the use of sulphur in lard to grease the heads. The lard is sufficient and the sulphur takes away proper use of legs; it is also liable to cause blindness. Use clear lard or thick cream Jiquid lice killer is equally dangerous if not carefully used. It may be put on the ontside of the coops or a little on inside after they are a few weeks old, provided it is done in the morning and the coops are aired well during the day. Never put it on the floors, for if the hen sits over it, it will suffocate the poults. This is equaliy true of little chiclis. I have tried it and know from experience. Yet there are no better insecticides than these liquid lice killers it properly used. They will lill mites and chiggers and everything in that line, even hedbugs, which infest hen houses in some localities.

Southern turkey breeders complain that many poults 
are killed hy chiggers, which do more tamage than any other one thing.

We presume this is the little grass chiggre which buries itself in the flesh-at least it does om peopleand is res? hard to exterminate and iery painful to endure. The had never thomght of this. The only remedy kuown to us is grease, and ton much of that is fatal to the ponlts.

In the late fall and winter lice are hard on turkeys -they cannot find good dust baths as they can in sumner, hence it is necessary to use mu best efforts to libll is sentererd than when it is given to them in pans. I hate long since discarderl feerling troughs in my poultry yads. They were a disadvantage to buth old and fonng. In ny rpinion much of the so-alled cholera' is traceable to the feerling lrough. Turkeys especially are naturally juclined 10 take a small quantity of food at a time and when fed in trughs they will fill their crops and du not talie runugh exereise to eause good digestion.

for fatteming I prefer coln to anything else, nn. loss it he crashed coln. Feed whole corn on the ear (1) se:tflep it in straw so they mast work to get it.

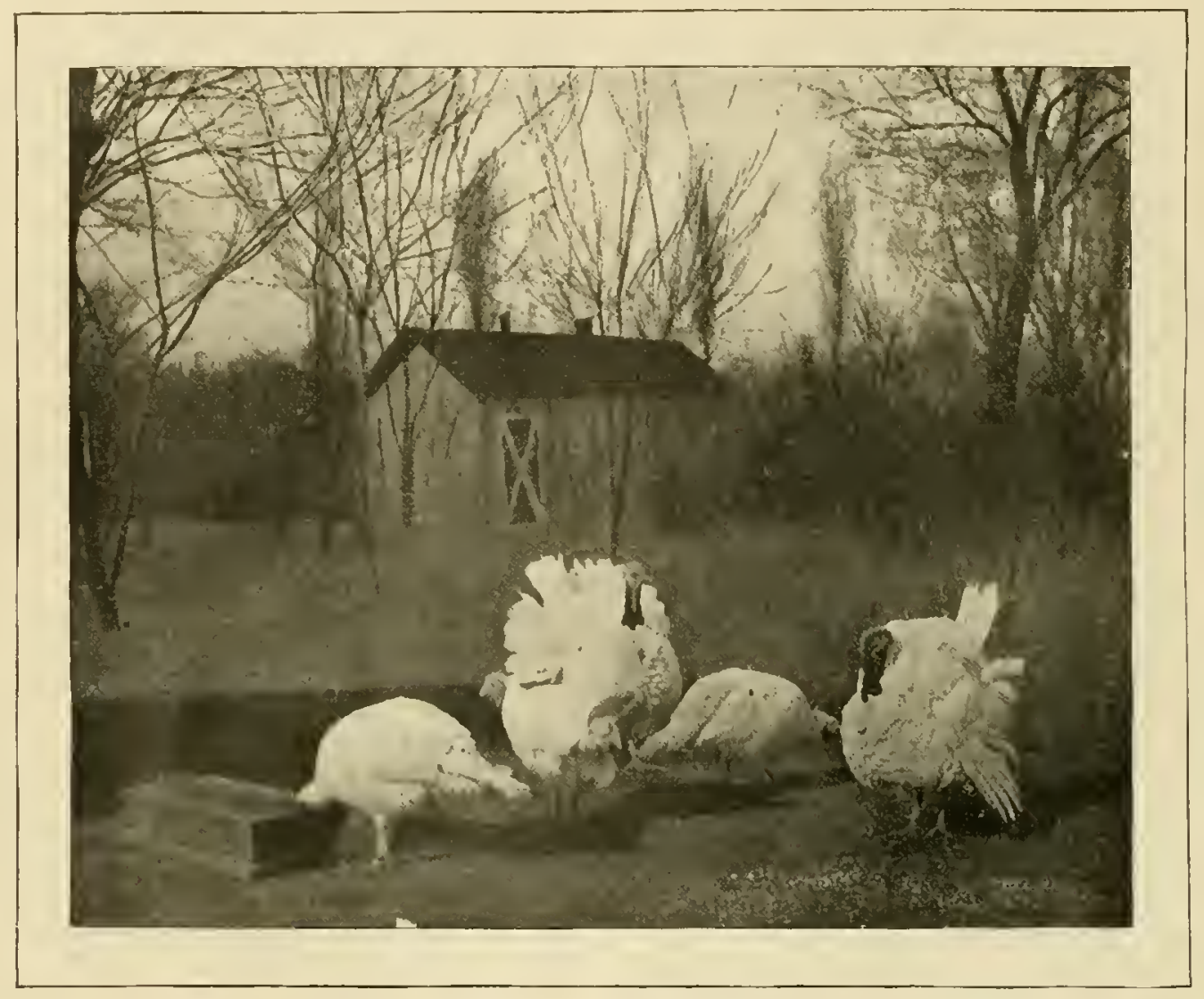

A Group of Hungrian Turkess

the vermin on them. for they eanmot thrive with vermin sapping their strength.

\section{PREPARING TURKEYS JOR MARKET}

Many persons wish to linow when to begin to prepare turkeys for market. The best time to lregin is when they are hatehed and keep up the preparation nntil they are put un the warket. If you live un a grain or stork farm let your turkeys lave free acress to the feeding stalls and wrain shocks and they will take cale of themselves. If ymu, like myself, are limited to a small place, the feeding must be kept up all the year. It will not do to increass the food ton rapidly at first. During the summer feed adnlt turlicys only once a day, lmit about Septemher I hegin fcerling them twice a day, morning and exening, all that they will eat, or lather, as I keepl the prirent stock in the pens. my plan has been to scatter the foud in the morning so that they shall be kept busy all day hupting for it. It niglit i give a full feed wherr they ean get it withomt any tromble, and gradually increase the quantity of ford as the eold weather appurnaches. I find that buth old and yomg turkeys thrive better ami eat murs when the fouxt
If you have nerer noticed the necessity of lime for turkeys wateh them pick whitewasl off the sides of homses. Make this clifference in the treatment of those intended for market and those kept 1 breed from: Fut all the food before the nurket fowl it will eat; make it an lat as possible-but if you get your breeding stock tuo falt, iufertile eggs will be the result.

Le sure you dis not wait until the day before Thanlisgiving to try to sell you stock. The highest prices are usually whtainable the week before the hollday feasts. Is i rule there is a great rush to market with turkeys 1 wo days before Thanksgiving. The rush uften eauses the price to drop just when the most was expected. I have known the highest prices to be obtained between Tlianksgiving and Christmas and in February: Of course the locality has something to do with the price, and there mar. in the same locality be different influences at different seasons. We bave to do as our husbinds do with their stock. Watch and sell at the most popitions time. If I had only a few I would sell all at ence, but if I raised from serenty-five to a lunnAred I sluwld sell at different tintes. ine ean sell the blest first, thus giving the younger ones a elunce. Mlar- 
Fet birds can not be tno fat, but they may be tow heary for the highest prices. I few farmess in our eomby understand this, and do not buy the langest toms to breed from: wthers rim to the other extreme, inbreeding and buying alls until their turkeys are tou small to be jurfitable. I should prefor large loreeding stock to small, even ip 1 sold on the market, for if 1 get a lwwer price the ditterence in pounds would more than make the difference in priec.

How much onght roung toms to weigh at Thanksgiving, is a fuestinn iften askerl me. That depends on when they were hatrhed. In early hatrhed, say one hateherl in May, will weigh from twenty to twenty-four poumls, and some few will go higher. One market poultryman says, that an average of eighteen and twenty pomds is the rule. while those going above that are the exceptiun.

I lave been askerl if $I$ think it better to dress turkey"s or sell them on foot; "which is the most profitahle?" The answer to this (as most answers are) is delentent. I have a friend who dresses her turkeys ahout the midklo of February for the St. Louis market. She says she malies money by so doing. I know others who say it loes not pay them at all.

The cause of the difference of opinion lies in the rlifference of surroundings. The larly who say's it pays her to dross her turkeys for market does the work herself and says she makes fair wages at the difierence in the price between dressed turkeys and turlieys on foot. My opinion is that the average farmer's wife had better sell her turkeys on foot, lont this is a question upon which there is a difference of opinion and one which each ane must hecide for herself.

I nevel sold a dressetl turkey, yet 1 linew how farmers' wires dress them for "mr market, and 1 dress them for ny own table the same way. We cut the heads off and let them bleed well and theil dry pick then and remore theip "utrails: washing them thoroughly with eole or luke warm water. Plump the "areass by pouring boiling watel ner it, then salt and let it freeze before enolsing, if possilule. Very few salt them to put them on the market.

Talk about turkeys eating their heaks off: If a man sells hous at fir rents a pound he thinks he is doing a tine business, says he is getting fifty cents a bushel for his enru, lut when a woman sells her turkeys even at eight rents a punnd she is toing far better and is doing ler husloum a clubble faror; it is a farol to him for her to jay her own and part of his bills; besides she gets eight cents a pound for grasshoppers. which but for her turkeys wond destroy the corn fodkler and injure the hay as well as ruin the eablogge.

\section{PREPARING TLRLELA PUR EXIIIBTTUN}

This one thing I never lose sight of $n$ forget the show room. Not alone for the seures I wish to receive (1) my bircls, but on aceount of the remembranee of what I gain at the shows in point of knowledge and the pleaswre I derive from assoriation with the many noble men and wounen to be met there.

Many timid ones are deterrel from entering the show roum beanse they dread eoming in competition with the moguls of the ponlty business. To such I say, comes! You have nothing to lose by the comparison and you znay be a winner of the prizes. It any rate you wili know what the julges think of your birls, and will learu low to improve your stoek. The show room is an erlucator and we neerl all the eduration we ean get if we in tend to stay in the lusiness. Nor dnes it follow that heeause they fail to win a jrize your stock is ponr. You will learn what it lakes to make a prize bird and what (unstitutes a good breeding bircl. Attend a poultry show or two each year if it is possilule for you to do so.

On large farms it is not necessary to begin heary feeding until the weather begins to get coul. But where une lais limited room they must be fed the year round. Do not select show birks intil they are throngh molting, if old birds are exhibited. I breeder of thoroughimed turkeys, fur sale as fancy stucl. must feed his entire Hock with an aim to getting them in condition for winter shows either in his own hands or in the hands of his customers.

Generally coeks may be defrended on molting true to the marking of the enckerel, but hens often are not as good in markings as they were as pullets. Still, l think turkeys are more regulat in their markings after molting than rhickens.

If a turkey is in a healthy condition the feathers will lie glossy, if nut. they will not be.

1 think that to keep turkeys liealthy and gentle and well fed is alout all the preparation turkeys need. It will nut do to put them in eonfinement longer than ten days. and then it will not do to have them in a strange place, as they will not eat. Give them all the corn, grit and lime ther will eat, with plenty of glass and water, and they will fatten.

llow do I manage to feer nuy turkeys to get them in weight for the shows and nut get the entire flock too fat? I keep only a few turkeys on my home place at one time, not more than lifty to seventy-five in winter and unly isy breeding stork in summer. Is l am continually thipping them I select the best in size and that leaves the smaller ones a better ehance to grow. I "annot separate those intended for the show room from the others, so 1 feed all alike and take the heariest to the show, no matter if they are not so well marked as the others, for it is the heary turker whieh wins in the show room. In faet. I have onty a few times taken my best marked turlieys to a show.

1 hare had rery few persons come to my yarts who knew how to eateh a turkey or ehicken, I can pick my turkeys or ehickens up anywhere in the yad with the assistance of one whom I have trained. In the first place I am very gentle with my fowls. I lalk to them when I feed then. You may wonder what I say. Well, I find they are like t!re human race, suseeptible to flattery, if flattery it may be called; 1 do not intend it as sueh, for I mean erer word of it. I call them pretty things-tel] them they are the pretijest turkeys anywhere aroundtalk to them about going to the shows, and tell them how they must behave to apprar well; in faet, I am nevel at a loss for something to say to my fowls. When I want to ratel one I prefer to go out in the yard, look the flock over while they are out, seleet the one I want, all ny assistant, and wuint wnt the turliey. Then I begin to feed and usually I ean eatch the one $I$ desire while they are eating. Yever rush into the flock or shoo a turliey. Very quietly step up hehind it and eatch it by the legs. Be sure to take hold uf hoth legs as you eateh one, then you can easily pick the hid up and it will not lap its wings and hurt itself. If there are several to atel and you do not wish to put them in different cuops it is better to eatch all yon need before eooping any. I (dhild ean hold a forty pound tom if he knows how. Just lay him flat on his side or hreast and hold his legs ciose to the thighs and he will not attempt to get away. I have often released one after hulding it in this manner, and it would lie still for one or two minutes lefore getting̈ r.p. 


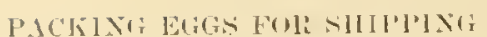

It may sound egotistical, but I believe I can pack eggs that will go around the globe without breaking, that is, with reasonable lrandling: yet last year the only chick eggs reported broken did not go two hundred miles, and hat they not been sent to a relative as a present I presnme I should have lieard about them with no

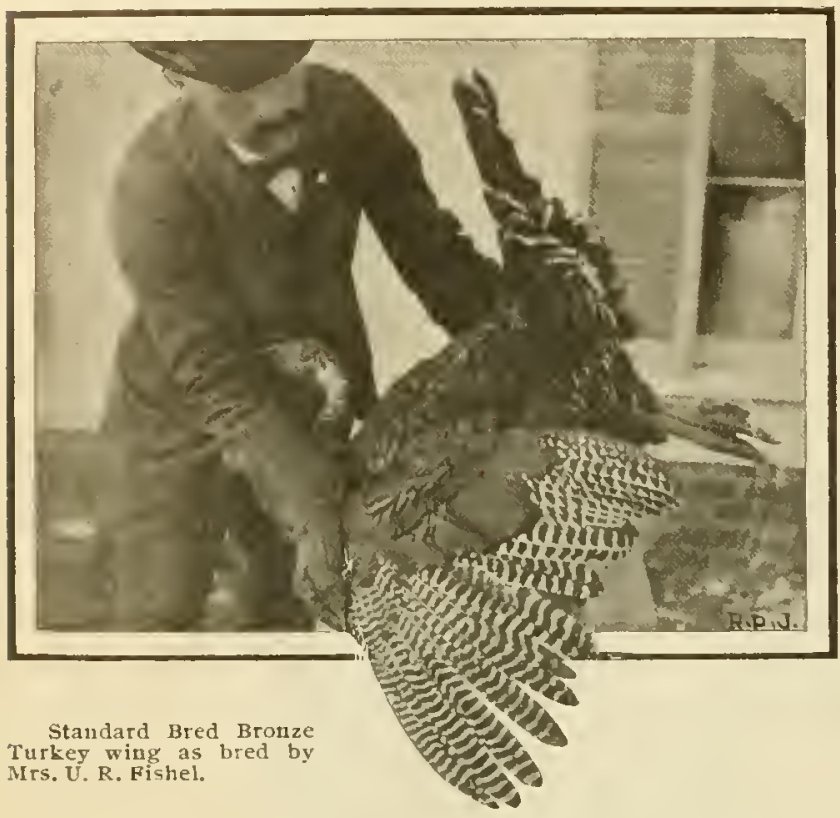

uncertain sound. They evidently had been pitched off the car as baggage and crushed under some heavy body.

First line the basket with paper, then put in an inch of hay chaft in bottom if it is a large basket and many eggs are to go in; if it is only a peck basket, threefourths or a half of an inch will be sufficient, but it must have a soft padding at bottom. Re-line with a good heary paper. Wrap each egg with paper, but do not wrap too tight; use plenty of paper and do it nicely. I always pack with the small end down, becanse the white is in the small end and the yolk will not break if allowed to float upon it, while if the large end is down there is nothing to prevent the yolk breaking from the jar of the travel. Of course if the yolk is broken the egg cannot hatch.

\section{Diseases of Turkeys}

\section{CANIEER}

I receive a great many questions as to what to do for sick poults. I am a poor doctor for little turkeys. I really believe that where the parent stock is not related ог inbred that it is poor management where there are sick poults.

Canker is more prevalent than many persons suppose, and while often a fowl may die before it is discovered, the rule is it becomes droopy and refuses to eat. The discharges become yellowish green, sometimes looking like the yellow of an egg. The canker extends often to the throat and frequently forms on the tongue at the opening of the wind pipe and stops the air passages.

To cure canker I have found Mustang Liniment better than anything else I have егеr used. If this cannot be obtained, wash in a strong copperas water and grease with carbolated vaseline, in which put a few drops of tincture of iodine. This is an effectual cure, but it takes longer treatment and is more trouble. But the fowl, turkey or chicken will need a tonic to correct the digestion and tone the system. I give a liver pill, any that I would use for a person. Give this at night and a two-grain quiniue capsule in the morning. A little copperas and extract of logwood in the drinking water usually cure the trouble. Use whatever poultry tonic or cholera cure you may deem best mixed in foorl. Make into long rolls and put down the throat, then give the water from a bottle. I also put grit in food. Feed only once a day while the food must be given, but when the turkey can pick food, give twice a day and separate from other fowls. If I use Mustang Liniment I put a few drops down the throat, for I think often the canker extends through the system.

If $I$ am sure there is no canker I omit the treatment for that and give the other treatment. Do not let the fowl have anything to eat or drink which is not medicated until you know it is well. The quinine capsule may be given every morning for a week, the liver pill every other day until three are given.

I have never lost a turkey under the foregoing treatment when I have been able to give it regularly. And several customers have reported that under my directions they have saved their turkeys.

\section{GAl'ES}

To prevent the disease ] use a little turpentine in the drinking water. A dash of flowers of sulphur in the fond once is week will be beneficial until they are well feathered. Copperas in the drinking water and onions in the food will generilly prevent gapes. Turkeys having rermin are nore likely to be affected. I have been advised to use sour cream instead of lard to grease young turkeys.

If I fiud the poults have gapes I put Dalmation or Persian insect powder in the food and have no further trouble. I sprinkle the powder into the food just as I would pelper. I have cured several chiclis of the gapes by first puffing the powder in the wind pipe. This kills the worms, and $I$ extract them with a gape extractor made of a piece of soft grass. If the worms are taken out the chicken will recover unless it is injured by the operation. They are casier to take out dead than alive and I find the powder good, but one has to be careful not to get too much in the wind pipe or the poult or chick will not be able to breathe.

\section{AIR PUHE}

One night I noticed that the neck of one of my young turkeys was so badly swollen it could not get its mouth to the ground to eat. I picked it 1 p and found its whole body in the same condition. The skin only seemed puffed. I took a pajr of sharp scissors and clipped the skin in sereral places. The air escaped and the turkey began to chirp. I put it with the others and it ate heartily. I put a teaspoonful of coal oil in the drinking water with a few drops of carbolic acid.

The next morning $I$ noticed its wings drooping down and it was as badly puffed as before. I repeated the clipping and this time I clipped around the neck; I went deeper than $]$ intended and the neck began to bleed freely. I felt that this would kill it, but I knew it would die anyway if not reliered, so I did not griere. I took a feather and dipped it in tar and covered the bleeding wound, then I greased it with pure lard. My husband said: "You hare killed that turkey." I replied: "Yes, I think I hare, but I was trying to save it." To my astonishment it came up that night as lively as any of the others. I cut both wings and in the morning I showed it to my husband. We were both surprised. Ten days after it was as strong to all appearances as any of the others 
and it never puffed afterward. I concluded the bleeding was good for it, yet I would not know just how to advise it to be done, as I did that by accident.

\section{BUMHBLFOT}

Iumblefoot is a hard place on the bottom of the foot which often becomes very sore and contains pus. It is claimed that it is usually caused by the fowls roosting high and coning down on the ground with such force as to bruise the foot. I am incliued to favol this theory, though some high in authority deny it. At any rate, turkeys and chickens are often found with feet in this condition. I wait until the sore becomes soft, open it with a slrarp knife and squeeze it until all the pus and the core, if I can get it, run out. If the core does not come out it will rum out in a few days if the foot is bound up with a good salve.

I find one of the best salves I ever used to be raseline, turpentine, a few drops of crude carbolic acid and tineture of iodinc. I cannot give the proportions because I do not measure or drop by count. I generally make about a teacup full in the fall or early winter and it lasts me all season. A friend told me that resin would add to its merits. I put the ingredients all on the stove and mix them together and the next time I make this salve I think I shall add the resin.

Salre is also good for sole head, but it is better to wash the head with copperas water before using the salve. If you can aflord to buy Mexican Mustang Liniment it is even better than salve, but one often does not have the liniment at hand and can make the salve.

\section{BOWEL TLOUIBLE}

The coops in which the poults roost must have plenty of fresh air as well as be rat proof. If the weather is cold and damp they must be kept in pens, so they can be horcred by the hen If she is at liberty she is liable to walk around in the weeds or grass and the poults will rhill and becume loose in the bowels. And they generally die when this disease is cansed by the above treatment. lluwever, if they are not too much chilled, pen theu up, make a very weak pepper tea and gire this for drinking water. Sweet milk is a good remedy for bowel trouble with pouits.

If rou do not orerfeed your young birds nor give them too mucl water while young, and do not let them get wet and chilled, thereby contracting cold, they will not have bowel trouble. They are not so apt to drink too much where they can run at large as they are when liept in confinement. When running at large I keep water where they can have access to it, but when penned up I give them a drink only three times a day.

Do not let the poults get wet. I am trying to plan a way to have theul roost on a dirt floor, yet not on damp earth. I think the clampness of the ground gives them rhennatism, or makes them delicate, but the hen mashes the poults on a plank floor. I think if the dirt can be thrown up around the coop, so as to keep the ground dry, it will be better.

There milk curd, seasoned with black pepper and salt, is fed for the first ten days, there will be no danger of loose bowels, provided other liealth precautions are observed. Lice will cause bowel trouble, as will too much heat. When caused by heat give a teaspoonful of carbolic acid in a gallon of water.

Keep the drinking fountains clean and fresh. This can be done by washing them out with carbolized water.

Logwood is excellent fol loose bowels. I have used and recommended it for years. There is no danger of using too much and there is nothing better for ordinary bowel trouble either in chicks, poults or grown forvls. It comes by the pound in boxes and sells here at ten cents per pound. I put a lump of it in a glass fruit jar, using as large a lump as I can get into the jar and pour warm (not hot) water over it. Every morning I put just enough of this into the Irinking water to color it and it keeps the bowels in a healtly condition. If fowls are sick I use it slronger.

Overfeeding produces indigestion and indigestion causes bowel trouble. Vermin and overfeeding kill more poults than all other causes. Lice will produce all the symptoms of disease. When a poult dies from overfeeding a post mortem will usually diselose the liver swollen and probably splotehed. When it is in this condition there is 110 chance for the poult. If taken in tine a raclical change of cliet will effect a cure.

\section{HOT MLAHES}

A lasly in Maryland writes: "l can't agree with you that hot mashes cause romp, for in my native lome (Canata) I fed my turkeys hot mashes from the time they were a fow weeks old until they were grown, and so did my neighbors, and we raised large flocks and were never trunbled with loup. Here I have not fed the mash and hive the roup." lioosting in trees may be the cause of roup in her flocks now, as she says they never had it when ronsting under shelter. I agree with her that in extreme climates a shelter is better. She also gives me a preventative for fighting which I certainly shall use. I

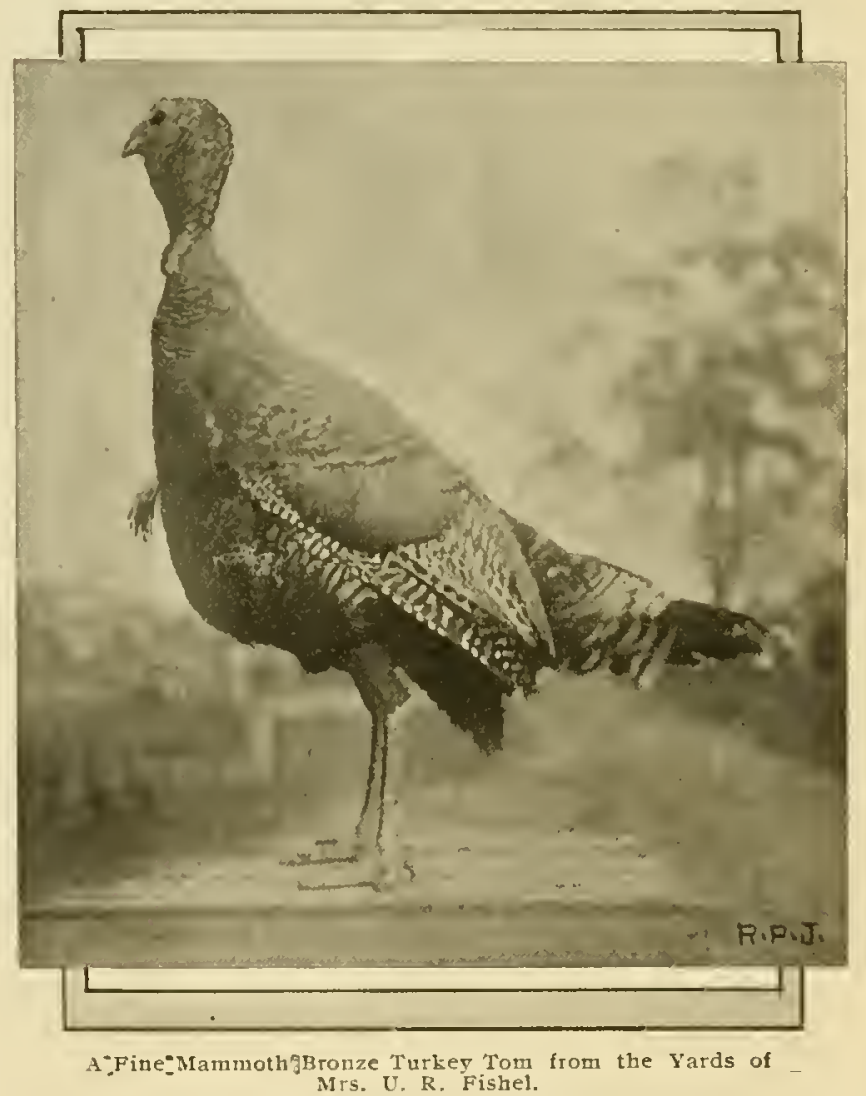

give it to the readers of this book: Tie a small bell around the neek of toms showing a disposition to fight. The noise attracts their attention so they forget to fight.

\section{CROP BOUND}

In the early spring the trouble most to be dreaded with turlieys is crop bound, caused from eating dry grass. No one can prevent this unless they have green 
fields on gain for them to lou in, rye on wheat fields. Exen them snmetimes they will fill their (rops with the dry grass, which forms a harl lall in the crop and unless it cun be matle to juss, it will lill the fowl. Sometimes after ashile without any treatment. cutting the erop. taking the substance the erop. and they say it never fails Jhis ma be trome with experts at the business, but witl ne it is a total failure. I tried it and thought jt was a suevess, hut several weeks afterwarl I discorered that the crops had never grown together where they were ent npen and the threal rotted out. so they died. I have lust some of the finest turkeys l ever wrned from this trouble and have culed others seemingly as bad off.

1 hare not fomnd an infallible cme and the most effecturl cure I have found is very tedions. I give the turkey a lose of castor oil or Epsom salts as soon as I finct it has the trouble. 1 hold it and pour all the water into the crop' I think it safe to gire and I also put a tablespuonful of miea crystal grit in some soft food. make it in long rolis and put down the throat. l'urkeys are easily ehoked and unless the food is made in long, slender rolls they are liable to choke. The reason 1 put the grit in the food is that it is liable to go lown the wind pipe if poured into the mouth alone. 'Then I rerg gently get holel of the ball in the crop from the outside and work it with both hands. having somerne else hold the turliey. I "an generally softrin the ball rery pereptibly the first time I treat the turlier. The grit in the ford gets into the sofrmed parts and helps diride the ball, the oil takes all that it is prossible to get ont of the erop, ont of the system so that it does not elog in the gizzard, as it is liable to do if not worked of immediately. The working must be very gently hone, as it brnises the crop. J repent this process every morning at first and gire plenty of soft fuml and grit sluring the thas.

If 1 discorer, as is olten the case, that the turliey is getting weak, I give a lwo-gmin capsule of qninine every morning. This increases the appetite and gives strength to the birl. I give plenty of mions in the food. The trentment must be liept uj until all the ball has entirely passed out of the system. I do not give the wil more than once a week after the first fer days.

One of the best toms I ever owned, a fuil bother to "Champ Clark:" who senred from 97 to 98 by every judge who saw him. was copp bound, and as I had sold "Champ Clark" I was amxious to sare the brother, which 1 cunsidered just as goorl. I thought he was entirely emred. and he was to all appealnuces well. lle had wained flesh and was as hearty as any birit on the place. I fed him at night and noticed how well he looked. The next morning I found him dead under the roost. He weigher forty pounds and of conrse lowked finer after death than I hac eonsiclerer hin in life. My only consolation was that he had waited until after the breeding season was almost over before he died.

On examination I found tlat a ball cuot a very large me, either) of dried grass had lodgen in the rent, which frevented anylung form passing, and this ealused his death. lle hat been from under treatmont about two montlus and I beliered if I harl continued the oil unce a werk he wonk have lived.

(jun I noticed a turliey with the sanc symptoms, hnt all my treatment avaled nothing and he died. I examined thim and found the gizzand packed with dry guss anci so nothing coulcl lave saved him.

"Mly turkess are affected with what $T$ (all prendant "xop. The crop langes down like al batg, sometimes low mough to interfore with walling and is filled with datk lirpuicl. The turlisys eat, lut are pale about the head. What slabl I do for them?"

Give them a teaspomful of haking powder: sola will not do. This is a dose for one olel turkey. I do not tinol the baking powder an infallible cme. but it is the best thing I have tried. Two doses usually cure. Keep the turlicy inelosed and do not feed until the powder has been in the crop an hour or two: then give soft food. wheat bread made into long rolls, and put down the throat. The roll must not be rery lauge. Do not wive any water mitil the liquich has passed out of the erop. I little salt mixerl in the foud will assist in carrying the impurities out of the srstem. Epsom salts are better than oil for [op-bouml fowls. You will lave to be very carefinl to keep water from them mil they have entirely recovered. or the crop will refill and the second attack is always worse or more stubboun than the hirst. It is very nunsual for this tromble to alise in summer. It is prevalent during the latter part of winter and early spring.

\section{I'HOLER.1}

The "ry of chulera among turlieys comnes to me from many persons, and these are not confined to a given loeality or state. From Mississippi, Wisconsin, Pennsylranja. Juwa and many other states 1 have received let. ters reporling cholera among turleys and often they say there are no synitoms of the tronble among the chiclians. The fact that the turkeys linger for days and sometimes even weeks is one reason fur believing it is not rholera. Another is that in many instances the chickens and turkeys are in the same yark and the chickens are not affecter; then. agrin, abunt the my symptom common to all inquiries is that the droppings are a yellowish green. Some describe the heads as black. saying they mope around and will not eat. Others say the heal is red to the last am they eat up to a few mimtes before they are seizesl with an attack like convulsions, and still others sar they have pontris muler the eyes. while another fock has a white substance fluating ores the eye.

It is a tact that almost any disease of a turliey will cause thr hopplugs to become yellowish green, showing that disease in turkers, like disease in the hmman family. somner or later affects the digestive morgans.

Often indigestion is the cause of the trouble. I am not quite positively certain that 1 erer had a genuine ease of cholera in my yarks. though I well remember when I thought every chicken or turkey that died had it.

I have bern informed he one of the R. P. J. colrespondents that there is a much larger per cent of deaths from what is known as black head than from - Moleris, and that it is infections. He says that what has often been junounced cholera is black head. IJe also informs me there is alssolutely no remedy fur it which can be relierl upon to be eren comparatively a cure, and that the canse is manown. This lye wote me some time since. lle said that Lee's Cremozone is the best remedy known to him. I had some experience with the trouble in the finch of a neighbor, and I decided it was cansed from werifeding while roung, and then turning them ont withut any food; at least $Y$ found when $T$ examiues atter death that the liser was perfectly soft and the gizand twice the size it slould have been.

1 hind numy persons use a great deal of red or rayemue pepper and soda in turkeg ford. Because I had been tanght to dn this I rial like my neighbors when I commenced raising tmreys. but I som began to ase my rommun sense ani 1 womexerl low wn wath anything could lise, especially a wee bit of a 1 melkey with the crop, filled with pepper. soda. suphur. copperas. also custard. 
milk curd aud many other things I was twil I would have to feed to be successful. 1 said: "I shall try a way" of my own," and whenever I have had the sellse to do my. own way I have snceeded in keeping my Hock healthy.

lied pepues is a good tonic tor chickens in culd weather if given in minute quantities.

I find earlolic acid in drinking water, a teaspounful to a gatlon of watel. is one of the best things to lieep their howels in good condition I have ever tried. Epsom salts and salt. a teaspoonful of each to al gallun of water, is also goocl. Too much salt will throw a turliey into fits, so will tou much tobace, but they will recurer from the tolaceo dust as soon as they get the fresh air, while from salt taken into the system they do not recover.

Whenever the droplings lowk yellowish I use my Cholera cure-nut that I believe they have cholera, but the clopplings indicate indigestion.

\section{RIELMATISI}

Several lotters have come in, asling what to do for lameness in little turkeys, describing the poults as being affected with swollen joints. I think this trouble arises from dampmess. Either the poults roost in damp places or excererlingly wet weather has been conducive to the disease. The trouble is donbtless rleumatism and the best remedy I know is elder bark prepared as follows: Get the bark and serape off the outside skin, cut in small pieces and put in apple vinegar. It cloes not matter how much bark rom put ius, but the stromger it is the better. Put in a half gallon fruit jal and adcl a piece of alum ats large as a walumt and the same amount of cupperas. l'ut all the bark in the jar fou can get in, pouring the rinegar over it. Put enough of this liquicl in the drinking water to make it taste of acisl. but not enough to be unpleasant to the taste. I am sure this will mevent the trouble if it does not cule it, and I think it will rure it, provided the ponlts are liept free from campness. I should use Ifustang also or any good liniment that I woull use for myself. I little tincture of iodine in the drinking water is good as a tonic.

I should feerl either a little black or red pepper in the fool for sereral dars. In that time if I found I could not mre the fowl I would kill it. but if it were getting betler I should continue the treatment.

Once I noticed one of my poults could not walk, one leg seemed to be perfeetly straight and the poult held it so that it appeared to be behind it. I rued to bend it and it seemed stiff in the joints. But I bent it several times a day for four days when it was able to walk on buth feet.

\section{ROCP CANKER-SWELLED EIES AND HE.II)}

I have cured several eases of so-called roup in the following mamer., I made a strong salt water just as hot as $I$ could bear my hand in comfortahly and dipped the turkey's head in it. completely immersing the head. I nse an old tin can for this purpose. I let the head stay in the water as long as I thought it safe for the turker. I then talie it out and give it fresh air. press the uostrils between my thumb and forefinger. If there is any secretion, this will start a ruming at the nose. I open the month aud insert a mop made by wapping a soft cluth (im a small stick, into the openiug in the roof of the mouth, dipping it first into salt water; then I dip in conl oil. I make a salve of earbolic acis, a few drops of lard, spripits of camphor, a teaspounful, a teaspomful of tineture of ioline ant anoint the eyes. liear and fill the nostrils and opeuing in roof of mouth. With a clean eloth I wiped the head as dry as possible, (I tried not wiping the heas and fomml it marle the turliey ton enlel) then 1 rubbed it hard mutil it was iry. Put a little salt and Epsom salts in the trinling watter. This will almost invariably ene the renu in its first stages. If a turkey has arrived at an alvances stage of xoup before it is noticed I would kill it as the only sure cure.

For rattling in the throat I find nothing better than (oul wil with a little molasses in it.

sometimes caluker is caused by fighting. I had a tom. for which I hatl paid \$1r, that got to fighting and had "anke' on the sicle of his mouth, eansed by the bite of the wther tom. All 1 dial for him was to paint his mouth with indine. lle was a vigorous, lealthy hird and produced strong poults. I also advise the use of Mexican Mustang liniment, used acenrling to directions.

Sometimes turliegs have a soft, swelled place uniler the eyes. The first thing is to put them by themselves. With the finger press the soft swelling, letting the pressure go towards the hill. The plilegm will go out at the nose in most eases. 'Take a sewing machine oil can and fill with warm water, into which a few dops of tincture of iodine have been dropped; if the water is almost lont it will he all the better. After washing the head in strong salt water as hot as ean he burne, inject the water foum the ean into the mustrils and the opening in the rowf of the mouth. Wake a salve of lard. turpentine. crucle caldulic acid. copperas melted in the lard and Howers "1 sulphur. Auriut with this. If this is dome once a day fur a week the turkey will he well unless it is incumble. If there is pus, an incision made with a shapl linfe to let the pus ont will be necessary. lunt the hird will need something to cleanse the system, and Cushuan's limp cure will be very fine.

Ilwwever, the trouble is likely to return if you turn the turkey out in the cold. If it is worth the trouble it it better to keep it in the house until cold reather is nver. Feed onions, sott fund. corn and plenty of grit. I find Littell's liquid sulplur will do for flowers of sulphur in almost every ase where flower's of sulphur is neederl. I thinle simple remerlies will eure almost any trouble if taken in time. Do not fail to give mions once a week during the fall and thrmenomt the winter. They are a safeguard against roup and any diseases cansed by eoll.

For canker sores try putting a little almm in the dronking water we day and copperas the next.

\section{WORMIs}

"Hy turkeys ate dying fast and I found worms in the droppings. What must I to for them?"

If the entire tlock is sick, give turpentine in drinking water and in the foos - a tablespoonful of turpentine to a gallom of water and a teaspoonful to a quart of food; also add a tablespoonful of Epsom salts to a gallon of water. Give both the turpentine and salts at the sane time. If only one turliey is thus afiected I would eatch it and give it a teaspumful of castor oil. intu which put five or six drops of tmpentine; then feed as a tonic eholera cure.

\section{MISCEILANEOIS}

I quote from an ols number of the Ii. P. I. from an article on "lurkeys as llatchers":

"Then I first latel in an English pouttry book of the French methor of nsing turkeys to hatch and eare for chickens, I had mo inculater and coneluder to try the plan. Late in the fall 1 sent ont in the eomutry anul bught a late hatehed hen turkey for very little money In February we prepared a box (with plenty of chaff wer a layer of horse manure) that could be shnt up to exrhule the light. Did not give either wine or whiskey but 
in two or three weeks she was sitting quietly on the china eggs and when taken off the nest to be fed would roluntarily refurn. I then filled the nest with hens' eggs, remoring them as soon as they began to pip to keep the turkey from wanting to leave the nest and putting in other eggs. After sitting three months slue was put in a vard with chiekens for the rest of the summer. We put ehiekens of different ages with her anil she reeeired them all with equal kindness.

"This year we have two turkeys besides an ineubatol. and after hatehing three sittings of eggs we thought best to take them off the nest, but one watched her ehance and went baek on the nest till I filled it with eggs again, so I let her stay. The other is laying and will be ready for work later if needed.

"They make earelul, patient mothers, are equal in that respeet to any hen, and it is a wonder that farmers do not make more use of them than they do.

$$
\text { C. H. A." }
$$

\section{FARMING OUT TURKLS:}

I am often asked if I find it satisfaetory to farm out my turkeys. It is perfeetly satisfaetory, beeause I have no one to raise turheys for me who is not in all respeets reliable; besides tliey hatch them earlier than I ean, as the twenty-five or thirty hens kept at home do not lay eggs any faster than I have ealls for them from the time they begin laying until the first of June. I have young turkeys now out on the farms that one lias to look at the seeond time to be sure whether thev are hens or young turlieys. Farm-bred turkeys do not get very fat, eonsequently do not weigh as heary when $\mathrm{I}$ take them as I would make them weigh to please those who demand the pounds of Hiesh. but the frame is there. Be sure you know with whom you are placing your stoek and you will have no diffieulty.

Eacli seasun teaches us sone lesson that is profitable to us for the next. I have learned to take only one floek of hens and pullets and another of toms on the plaee at one time. When two or more flocks are brought in at the same time they fight so they will not eat and do not fatten. I find it better to pay board for a few flocks on the farms than to hring them together on the home plaee. I eould not raise all my stock at home and fnrnish pairs and trios not related, nor eould I ship as I now do to the same eustomers every year and insure a change of blood.

To those persous who have written me, asking if I think it will pay to raise turkeys, I can only say that I have never heari any me who has given it a fair trial say that it does not pay. Still I would not advise one to un dertake to raise turkeys who is not willing or physieally able to expose himself to all sorts of weather, both hot and eold. Turkeys must be kept dry while young and gotten home early in the afternoon.

How shall foul succeed with turkeys? The best way to snceeed is to keep on trying. If yon fail this year. get more in rarnest and try again next rear.

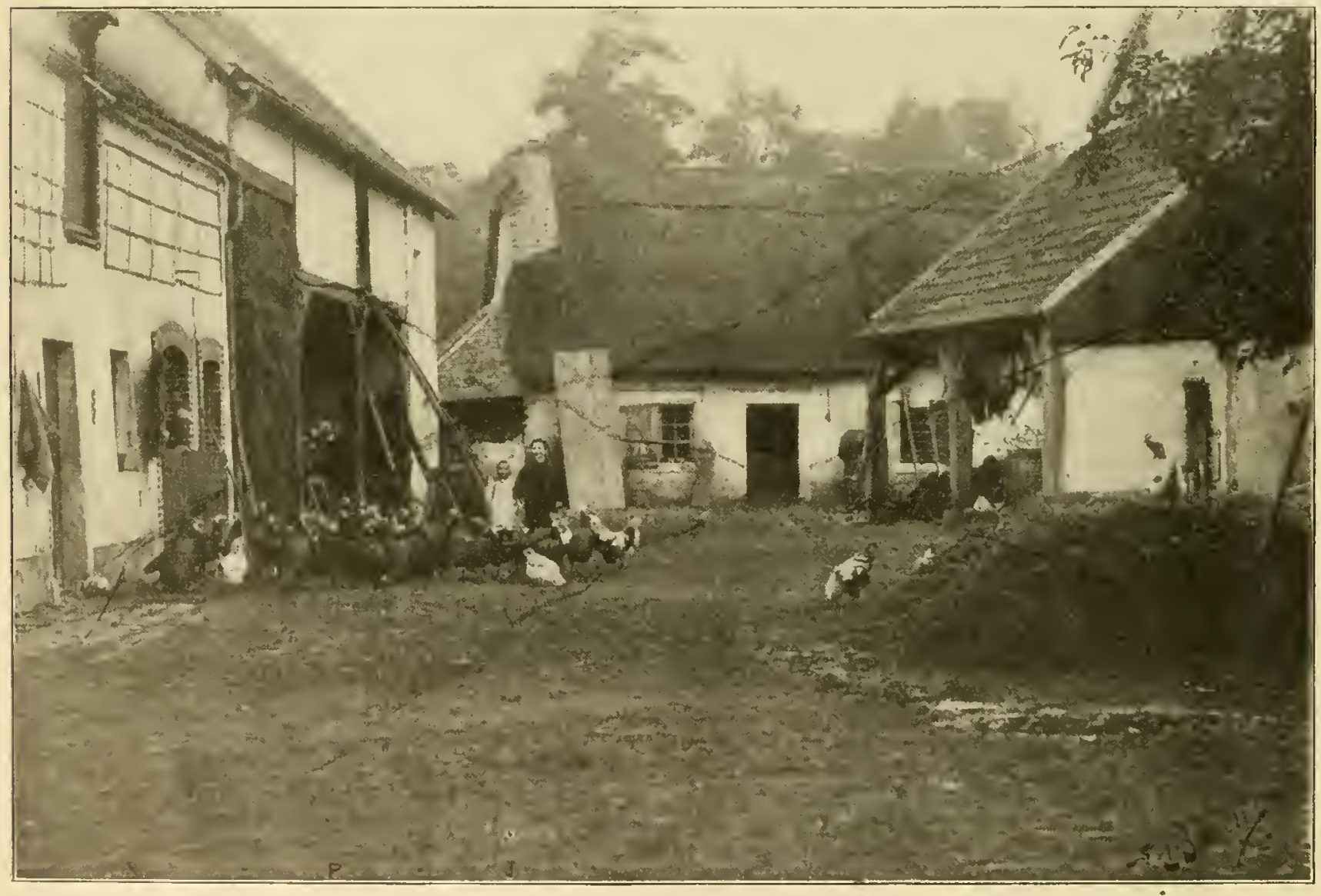

A flock of Black lutkers and Faverolles in a quaint old French Barurard. 


\title{
THE METHOD OF A SUCCESSFUL BREEDER
}

\author{
Introduce New Blood Each Year-Keep Poults Dry And Free From Lice-Feed Carefully-Do Not Crowd
}

\section{MIRS. II, R. SCHLOTZHAUER}

HE first lesson that should be learned by every turliey breeder is that it does not pay to inbreed. New bloorl must be infused every year, otherwise the flock will lose strength, size and rigor and be more subject to disease. We generally get our new blood by buying egrs from the breeder of the best stock we are able to locate. We hare to pay one dollar per egg or ten dollars per dozen. In this manner we do not inbreed and we find that the vigor and size of our flock is maintained without trouble. We have lad young to $\mathrm{ms}$ that weighed forty pounds when nine montlis old a nd pullets that weighed twenty-five pounds when the same agre.

\section{liREEDERS}

We have fencerl in our orchard and in this is kept onr lest breeding pen. which consists of a fine fifty pound, one year old tom and five nice, large, one year: old hens. $\mathrm{By}$ keeping them confined in this manner we are able to find every egg that they lay.

Do not try to fatten turkeys dur. ing hot weather. If

they are on free range or in a good orchard where they can find plenty of nature's food, just feed them at night and let them forage during the day. In this manner they can be kept in good breeding condition.

\section{TCIING AND FELING TIE POULTS}

It is much better to lieep the turkeys away from the other poultry.

Just as soon as we get fifty eggs, we set them under one turkey hen and three chicken hens and as soon as we get forty more, we do as before.

At this writing, June first, we have eighty nice, strong, little poults doing fine. The first hatch of fortyfive we gare to one turkey hen which is confined in the orehard and through which she takes her brood from one end to the other. The second hatch is with another turkey hen and is kept in the front yard.

We have a rat proof house, $8 \times 10$, with a window for each brood. We keep them shut in until the dew is off the grass in the morning and on rainy days they are kept shut in all day. I dust them every week with a good insect powder.

The little poults get their first feed when they are about thirty-six hours old. This feed consists of stale light bread, that has been soaked in sweet milk and mixed with a little lettuce or onion tops chopped fine and seasoned with a little pepper.

After a week or so, they get some cottage cheese mixed with rolled oats. When they are about two weeks old, we mix in some clean wheat, gradually changing. until they are getting all whent.

We put them on free range when they are about one montls old, but see that they come up to the orchard

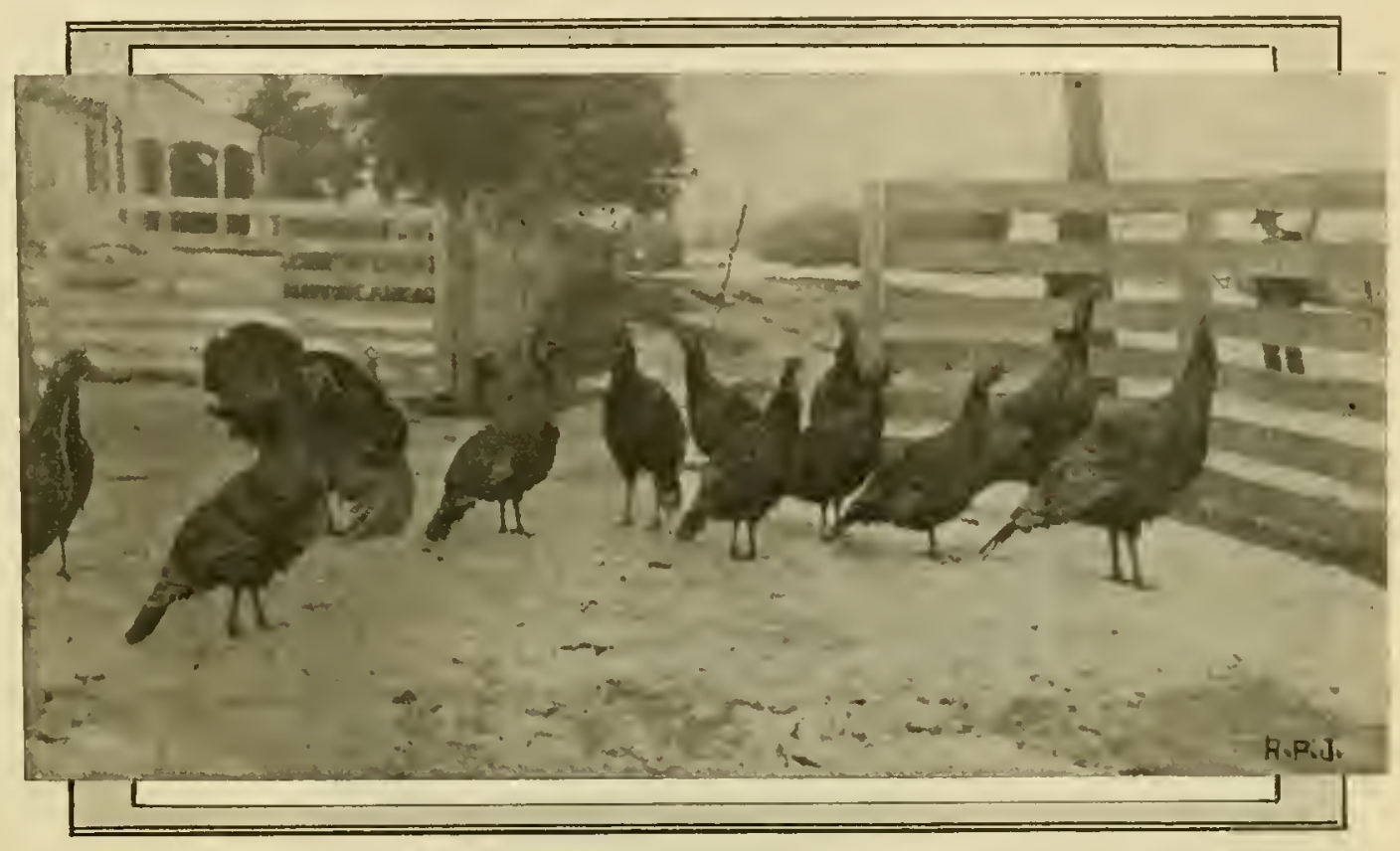

MAMMOTII IRONZE TURKEYS ON THE FARM

every night to roost.

Good grit, oyster shell, charcoal and fresh water should not be forgotten as an important part of their ration.

It is a pleasure to see them grow, and when Thanksgiving eones, we cannot lielp but feel proud of our tnrlieys.

We raise from fifty to one hundred each year and sell a good many for breeding purposes. We also sell quite a lot at market prices and consider that there is a good profit in raising turkeys for market.

We send some of our best ones to the poultry shows and State fair eacl year. If one sends turkeys to a fair or show, they should be sent in cages or coops, about $4 \times 4$, as the coops furnished by the show associations are not large enough, as a rule.

When cold weather comes on it is safe to feed them a little heavier and if possible get them to standard weight and a little above. First get the frame and then you can put on the meat.

We trust that our methods may be of benefit to some amateur and help him to snecess. 


\title{
THE POPULAR BRONZE TURKEY
}

\author{
Improvement-A roid Extremely Large Ones As Breeders-Selection of Breeders-Feeding-Varmints-Lice- \\ Feeding Poults-Selling and Shipping
}

FMSET F. PILLIN, Secretary-Treasurer, National Iironze Turlkey Club

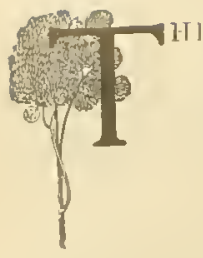

Jate of war first comnection will the Bromze "lumlety is lust in the haze of early revollection. We first hegan hreesling pure strins of this breal in 149 ;.

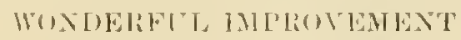

There has lowen consiclemble ind prosement in falley puints since the

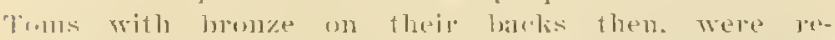
malliable, now we oxosimually see frullets almost as rich in that sertion. We see better tails and wings, lessi green and hrasis. and mole bronze in tail proved. In our opinion. the partical points have not

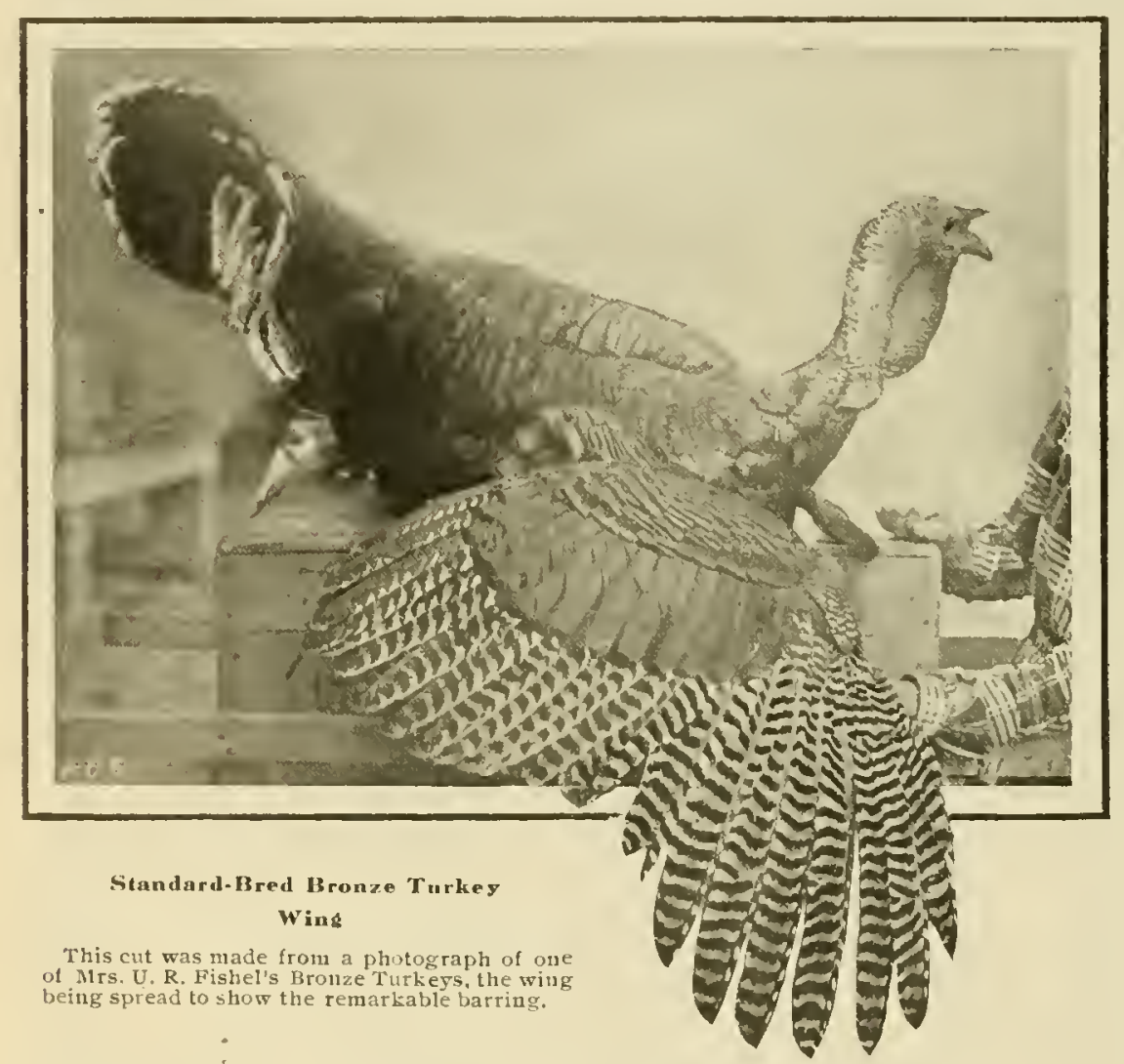
corets. 'l'he whita tijs have also bon comsilerably im-

more lind to mature than the melinm sized ones. The furmer ire seldon rea dy for the Thanksgiving market, the most protiable time to sell, becase thus far they have repuirtil sry litile grain. From then on to Christmas walliet they must be ferl liberally. Mnch more emuld be witten under this heading. but we think the present will suffice to slum the folly of onging to extremes.

\section{SELETTIA TIE IBELUER}

Is the futwe usefulness of the breed rleprous largely

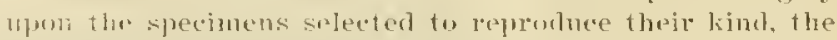

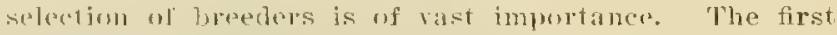

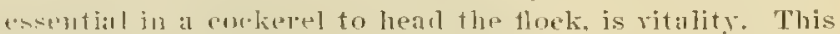
is inflicated ly a full breast, wille bark at butts of wings and a grout depth from back to puint of hreast bone. I willinguess to tisplay lis monze and vocal ability at a slight provoeation are furthre eriinuce: abrill slugerals. Choose those with snaj). Jears of experience con vinces the writel that the weiglt de. mamed hy the present standare] is sufficint. Iroin extremes.

The simu gentral principles hoh? gond in solesting pullets as in coreks'els. Choose those that are well de veloped, having plump, well-romuded loolies. Tf the aim of pom selection is to probluce prize winnel's as well as marliet fows. the eomplieation of your undertaking is inereased many times. Sulcess in this firection re. gruiles long experienee, a stury of the Stumrlard, and some acquaiutanse with the laws of inheritance. If the thuory that like protuces like, were infallible. plain saling would be assured. Wut it is not. There is a constant variation, othelwise there amid be no improment. The breselel with alsility to propery value the immortane of evely section, has acemmplished a fine art, but he who call take tlose that are of a high uass and mate them so they will prodnce a large perrentage of bean implower. Is a market fowl the bronze turker. leaves nothing to be desirerl either in appearance or merit.

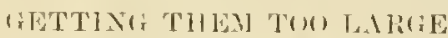

The whe thing that has threatened to roh the oreed of its unirersal popularity has been the craze to increase its weiglit. which is already in excess of aly uther hreed. Iixtra latee toms ofter wound aud sometimes kill wutright, finales in the breerling season. Extra large hens profluce a smal] percentage of eggs that will hatels. [1]shaperl,thin ar suft shelled eggs are invariably the profluct of large, geuerally very lax ge liens. Thus you see, nature would eliminate the overgrown. They are not in faror in market circles, the final testing of the great majority. The young that survive from the extra la ro stuck, require

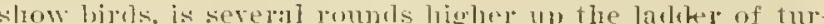
liey fame. They will stant a limited amount of inlureeting with aroul results. Thuse that prove themselves remark-

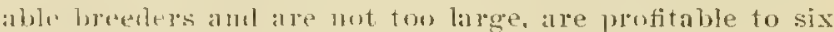
(1) eight years ull.

\section{FElloli:}

The tenciency in the corm belt is to get breeders too fat. We think beter results would follow if no eurn at all were aliower. Wheat. oats, buckweat, peas and the like, make good feed, which shoull be given rather sparingly. 'They' unst luare gravel and oyster shell in the lating seasun.

REMETHES TUR TLRlEEV PWTS their elnsive smartness is hard to mateh. Our remedr is
In some localities crows are a great nuisince and 
to take a few hen eggs, break a hole in one end, take out palt of the contents, put in a small yuantity of stryeltnine or arsenjc ausl stip well. t'lace where the turkeys are not liahl. to find then, or the woug birks may get the dose.

A small handtul of some gomd lice or insect puwder should be put in the nest, or better ret, on the hen il that ean be done without too murh hinger of breaking the egres. For lice on the gomme we think the following ly far the best. 'Jitle a bottle and till ome-fourth full with fish berries, finish with aleohol and let stancl twenty-four hours; apply with a small hushs, I small cuantity is sufficient and sule deitls 10 line.

\section{CALINE FOR THE lOLLT.}

Provicle a pren or sume grassy spot about sx10 feet, ? feet high. eovered with wire netting for the broml. The first feed may be hard boiled eggs with onions elupped fine. Inother splendid feed is dried bread moistened in whole milk, squeezed almost biry; to either feed. some powdered ehareul should be adderl, whith serves as grit and prevents sommess of the eroj, the ranse of many deaths. Later, cracked wheat and nther suall grains sueh as chiekens thrive on may ly, userl. little eare will be required through the summer seasom. It will not be out of place to offer them some grain in the erenings when they refurn from their foraging expedition. They
Jicl the tirlus of large quantities ol weed seed and injurious insacts. When the supply of these becomes short in autunu, nothing is better than corn.

\section{SELLJNA I ND SHIIPPINA:}

(Hur niethud is to sell on the marliet all stock which we think umwortly to be used as breeders. In shipping breeders, we prefer to use narow boxes without crachs, except on top; the sides may he lined will praper to prevent muthe mussing of the wings.

On long joumeys, il feed box and water resiel should he placed in the front end. In such crates, we have shipperl to the l'acific coast. Where turkeys arrived in splemdicl slape. We lo nut take any special pains to prepare specimens for shows. I long pole supplied with a leg look is used in catcluing them. We have probally prodnced some of the largast toms of the breed, ane weighing fifty-twn and one-lialf pounds, another weighing fifty-une and taling first in one of the large shows, where we refusen a high price for him. Howerel, we hate learneci a guni many things about extra large turkeys since then.

Gther delicacio's may have their hay, hut a Christuas without a Christmas tree or a bourth of July withent iee erenm womkl be no more likeking than a "lhanksgiving withont turkey, when from the newsboy in the street to the Presilent in the White IIruse this is the most popular birl in the ['nited States.

\title{
TURKEYS FOR PROFIT
}

\author{
Turkeys in Demand-Varieties-Enclose the Breeders-Fencing-Mating and Housing-Overfeeding-Late Hatched Turkeys-Green \\ Food for Growth-Freeing From Lice-Results of Line Breeding-Supply Grit Observation \\ and Care Necessary to Success
}

\section{IIRS. GIIA LRES JONES}

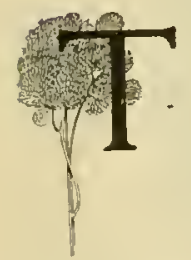

LRKEYS have lwoll raiser longer than the memory of those now living can trace and still the business is in its infancy. People are realizing eacoh year that it is ome of the most profitable arops of pomltry that ean be raised un a farm from a marliet stamlpoint. From the fanciers" ontlook they are maling such great strides in size, weight and plunage, and command such high prices that they are toubly profitable.

If the exhilits of Tronze lurlieys at the Chicago show are any eriterion, the business of raising Bronze turkeys has reached a point that nearly eelipses all other departments of poultry raising. When one yearling tom will bring $\$ 50$ and a pair of young turlieys $\$ 75$ it proves the ralue of the goorls, and these wore the prines asked and paid for some fine sperimens at Chicago not long ago. Immerliately breeders put up prices on eguss from 50 eents to one doliar apiece. From these faets one ean safely eonclume that the limonze turkey business is booming, especially when the last year has seen more turkeys shipped to foreign aontries than ware erer sent before. The turkey has beell basely slandered and has heen eonsidered to be about as stupid as a mule. I have never harl iny experience in tring to feach a mule to keep his hiud feet on the mround when his hest friend stoon behini him, but I bave tanglit 1urkoys in respeet my wishes and stay on one plantation.

Seeing a fomr-horse lond of turlitys unging to mathet gathered form four farms. I said, "surely 1 must go and
Wake "lu liip Van Winkle, sn that re may see what the lespised Oll Woman's hen business' is now." When he went to sleep ahout twelve hens and one rooster was the poultry efuipment of a farm, and turkeys were wild in the forest. If perchance a hunter brought one down for Christmas or thanlisgiving that was all the penple of 1huse days expected.

The newsings of Chiengo were presented with orel. two thomancl turkeys for one Thanksgiring feast, ancl I really do not know which to pity most, the turkeys or the newshoys. 'The poultry business at Swift's poultry parking houses in Chicago pomises to equal, if not exceed, the hug patking intustry.

As our population increases the great traet of land nsed for grating will be taken $n$ p into farms and the great dreres of cattle now raised on them will he a thing of the past. Pork is not good for a steady diet, am the people will clemand an immense number of turkeys, chieliens, ducks and geese to meet the defirit caused by the lack of cattle.

\section{WHITES, BLACKS, JUER AND REDS}

I am frequently asked how many varieties of turkeys we lave bred. I have only bred the old-fashioned serub and the Exomys. I prefer the linonze to any other variety I have erer seen. as it wrows su rery much larger, is harly and it is such a pleasure to have a flock of these brillinut beanties around. I think it is easy to get a grood libonze near to standald requirements in molkings, brilliant plumage and weight, although there has boen 
added punul after pomnd to the weight clanse, and one has got to get them almost as large as a calf to answer the requirements in weight. I think the weight is too high, as a turkey will shrink from one to two pounds while en ronte to the show. I have had them weighed in the show room where they have shown a shrinkage of orer three pounds. It is a settled fact that the Bronze turkey matmes slower than other varieties, as they grow until four years old. I think the Black turkey comes next as a desirable turkey; they nearly equal the Bronze in size and beauty. I breed the Bronze now for size and beauty as well as for their popularity. There is a great demand for them. The White Holland comes next in popularity. They are liked by people who bave small range, as they are what one may eall a domestic tnrkey, not given to extensive wandering, and possess very little of the wild spirit. I am quite partial to white fowls, but on acconnt of hardiness and great weight, as well as beautilul plumage, 1 prefer the Bronze.

I once owned a trio of Black turkeys for a short time. In one of my orders for turkeys to go to Europe I had a call for a trio of Black turkeys and a trio of Buffis, and as 1 did not breed them I had to find some goorl enough to ship across the pond. I sent to a well known Oriv judge and he sent me a Black tom that had nerer been beaten in the show room, a pullet that tooli first premium at the Ohio State Fair, and another equally as good. Well, that trio was so dazzlingly beautiful that it almosi shook my allegiance to the lironze. If ever I should change my breed of turkeys it would be to take up the Black turkey. I also got a rerg fine trio of Buffis from a reliable breeder in our own state and those with the trio of the best of my Bronze birds made a shipment that any turkey brecder miglnt be prond of. The honor did not all belong to me, howerer.

\section{MATING AND HOUSING}

l am in receipt of a very interesting letter from a lary in Ohio in regard to the Bourbon Red turliey. She has bred them only-one year. Her tom and hen were both young and to that she attributes the weakness of the poults, but as only one died a natural death it goes to show that they are quite hardy. They were very large when first hatched and very pretty. They are about as hardy as the lironze when raised under sinilar conditions, and make beantiful birds when grown. They are marked something like a peafowl, are very quiet and not much inclined to wander and want to be left entirely alone to attend strictly to their own bnsiness. My correspondent thinks that for a market fowl a cross of the Bronze and the Bourbon Red would give good results.

I am often asked which is the best way to mate tur. keys-young toms with hens or old toms with pullets. I like an old tom, but sometimes one suffers a serions loss among the heus, resulting from injnry caused by a vigorous male. I always make cots for the spur's the same as a finger cot, and wire them on the legs with a fine copper wire. If the spur is very sharp we saw the sharl point off and cnt the toe nails iery blunt. 1 find this an indispensable treatment if onc expects to escape loss.

correspondent aslss how many turkeys she ought to keep, and how many beus and toms she should buy to begin breeding on forty acres of land. She is building a house for them. I wrote and told lser not to build a house for turkeys, an open shed is all they ever need. A high shed covered with prairie hay or anything that will keep out rain and sun. I think when the Ever Rnling Hand made turleys He make the sky their covering. I really do like an open shed for rainy or stormy days and when the terrible blizzards sweep over the country, but you might as well try to chain the lightning or hold a cyclone in the hollow of your hand as to attempt to make turkeys break the laws of nature that made a roost on the topmost branch of the tree an ideal place for them to spend a cold night. While we cuddle down in a warm bed. they ale taking a constitutional on the tree top, sway ing in the blast and they come down full of vigor and with an appetite that almost equals the ostrich. I nerer try to control them as to their quarters for the night unless we have a severe ice storm, or one of our terrible blizzards. 'The rest of the time they are left to "paddle their own canoe" at night. When the Creator put into turkeys the instinct to sleep in the open air He knew more about raising turlieys than I do.

As to the number of birds my correspondent shonld begin with, I would under no eircumstances get more than ten hens and one tom. I stitrted with three thoroughbred hens and a tom, eren thongh I had raised turkeys for some years before this. I always advise inquirers to begin upon a small seale in any branch of poultry raising. One may work into the business and will not then lose the money invested, nor think the business is unprofitable. One turkey hen will lay two litters of eggs in a season, and this is all it is profitable to have her lay, for if she laid a third litter it would be too late to bother with them. She usually lays about thirty eggs in two litters, sometimes more, sometimes less. If this lany raises one bundred and fifty turkeys from ten hens she will be doing well, as the eggs ivill not all hateh and the poults will not all live. There are always some that are weak when first hatched. One hundred and fifty turkeys will be as many as should be kept on forty aeres, for they are not like chickens, they must have range and must lunt for the larger portion of their food if it is desired to raise them to perfection in size, rigor and llumage, and of course it is.

Turkeys raised on a large range are best to use as breeders, as they develop on nature's plan-bone, muscle and frame. and that is what we want instead of heavy weights and small framcs. Some people think weight is the criterion of excellence in turkeys. I wish I conld take them out with me in my morning rambles and show them the points of excellence my birds are developing by roving around and picking up the food that natnre contributes so lavishly for their benefit. The large, long legs and well proportioned bodies with the morning sun glaneing from their brilliant plnmage make a sight worth secing. Fxercise and the right kind of diet go a long way towards making a perfect turkey.

The Bronze turkey does not develop until four years old, and it stands to reason that a bird which develops slowly and liealthily will make a better breeder and produce lrealthicr and larger stock than those which are pushed to maturity, and which attain great weights simply by over-feeding and lack of exercise. First secure good health and a large frame, then let nature put on weight at maturity. If this course were followed we wonld not hear so much about diseases and non-snecess in raising turlieys. They were created for a special purpose and inteuded to be healthy and when we undertake to run against nature there is war at once and we have to pay the penalty.

\section{YAIDING AND TRAINING TURKEYS}

I raise turkeys and like the business and attribute much of my success to keeping my turkeys yarded through the breeding season. People generally think it a great expense to build a fence that will keep turkeys 
in, though I do not find it so. A three-foot woven wire fence with barbed wire above to make the fence four or five feet high will keep them confined if the flight featlers of one wing are cut. I keep the young turkeys yarded in the same yard until they are six weeks or two months old, which makes it convenient to protect the young poults from the wet and I can look them over once a week for lice, and never have to be luunting up my turkeys.

People ask me if they are not hard to raise. I raise a larger pel' cent of those hateled than I do of chickens. is generally enongh. I have had them caught that way and hang until dead. I use the breeding yards for the young turkey's until they are large enough to drive out on the range, putting fifty in each yard. It six weeks or two months they are driven onto their summer range, in'iving them home at night until they have learned the tricl of coming home to roost. There is consiclerable work getting them started to run out on the range and corne home at night. If you ailow them to run at large and stay ont at night they will wander away to neighbors and sometimes go miles from home. but if they are

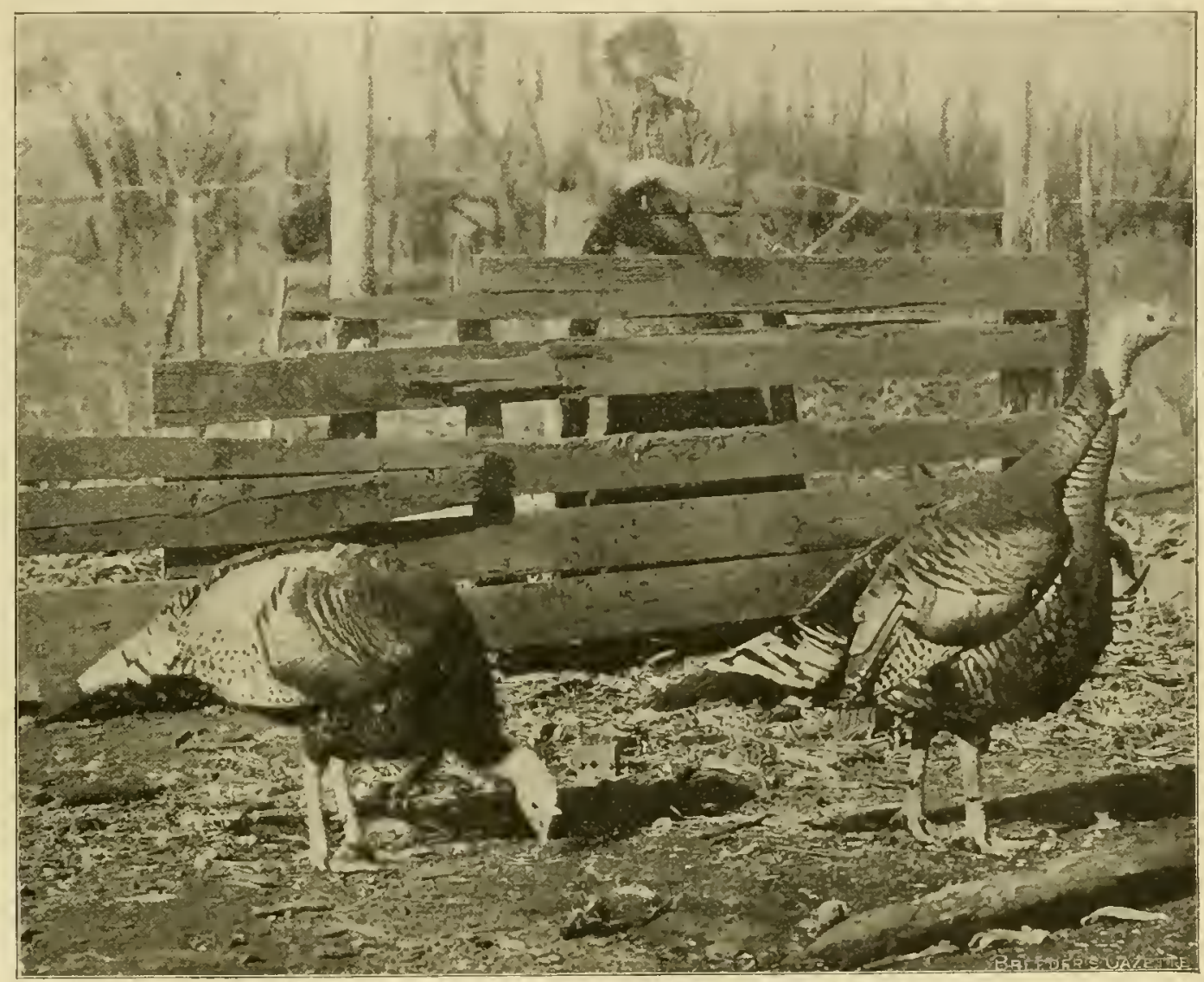

A Pair of Mra. Chas. Jones' Prize Winning Bronze Tarkeys

For the last two years I have raised over 95 per cent of all turkeys hatched.

I have found that fifty turkeys in a yard or field are enovgh to do well. If you keep more than that together. they are apt to pile in together and smother after they are about a month old. When I get a flock of fifty I start another drove in another field. I set four or five turkey hens and at the same time give to domestic hens as many tnrkey eggs as I think the turkeys can take care of. If possible I set an incubator with chicken eggs. When they all hatch I give the turkeys all the poults and the domestic hens all the incubator chicks, and that makes business lively all around, and keeps me very busy.

I raise from three different flocks of turkeys, ten hens and one tom, in each flock. We hare from one acre to three acres fenced in with a three-foot wire netting. three-inch mesh, with barbed wire at the top, making the fener five feet high. Turkeys will never try to fly over a barbed wire fence. They will crawl nnder if the wires are not close together, but they will never try to fly over it. If they ever attempt it they are almost sure to rum a barb through their foot and one experience of that kind driven hone niglitly for a week or two they will soon come home of their own accord, and then your work in the tnrkey yard is ncarly over, as they can take care of themselves, only you must watch that they do not forget to come home.

Turkcys like a large range as they grow older, but while young. one to three acres malies plenty of range. You wiil soon find out when they get dissatisfied with their quarters, as they will crawl out or fly into your garden or yard, showing that they are anxious to start on their foraging expeditions. If the hay and oats are cut so that they can get around without trampling things down, or finding too much to hide in, we turn them out.

Turkeys can be made to go almost anywhere their owner wants them to by driviug them to the farthest fields when they are first started ont. but they must be brought home nights until they learn to come home. I bonght a telescope to save steps and I find it a very great help, especially as I have to watch my turkeys on account of the railroad track. In the early dry part of the season I had a great deal of trouble with my turkeys wanlering so far that they could not get back at night. We 
discurered that they invariably went where they found water last year, and we concluded it was water they were after, so we took large dishes and put out where we wanted them to run, and then they only went abont onehall mile away and stiyed on onr own place. Their going where they found water last year shows that turkeys have memories. I beliere animals have much more intelligence that we give them eredit for. Only their language and way of giving expression to their wants is all Greeli to us.

To show how turkeys measure time our turkeys inrariably start for the house in time to reach the west (') of the pasture at four o'clock, and it takes them urijl about sundown to reach the house near where they loost. Now, how can they tell the time of day, which the seem to do as well as we do?

I did not learn in a day nor in a year the art of raising nearly all the turkeys hatehed, nor until I had lost hundreds each year, I acting as pall bearer and chief monrner, and I assure you I filled the position of mourner admirably, weeping copiously over buried hopes (and those hopes were of a well filled purse).

I hope I shall not have to meet those turkeys in the next world anil be held accountable for my unpardonable ignorance, but perhaps, by sincerely repenting my past mistakes the sin of ignorance will be forgiven me. If I can be of any help to those who raise $\$ 50$ and $\$ 75$ turlieys it maly lielp condone the past. May our great American Thanksgiving bird soar still higher and grow bigger and reach the thousand-dollar mark. He is sure to lave his praises sung in foreign tongues, and the fun of it all is, llow is he ever with his stupid brain going to learn those foreign languages, when they call him to breakfast, dinner and supper? How will he know what it all means?

\section{XDIGESTION}

A turkey grows very fast and has an appetite like an nstrich, but without an ostrieh's digestive ability. As the natural way for a turliey to eat is to pick up a grain bere ant there in sueh a manner as to give the digestive organs a grain at a time to digest, then the digestive mill grincis slowly without being clogged. This method of feeding keepe up a steady circulation and the turkey leeps powing larger and stronger, the digestive organs leing developed as the turkey grows, and they are therefore better able to do their work when more food is required to be ligested to build mp a large frame. On the other land, when the poults are overfed, the machinery is clogged and there is a general smash-up, the effect heing similar to that caused by throwing a bushel of ("olm into al coln slicller. 'l'he machine will do its work all right if ted slowly. so will a turkey's digestive organs. 1 turkey is a roracious eater and will eat as often as you feed it.

There are other causes that will bring death with rery nearly the same symptoms. One is lice and one is lack of sharp grit. A turkey cannot grind its food without grit any more than a miller can grind wheat without millstones; we might as well try to chew our food with-

neighbor told me that her turkeys were dying and I sent her word to come ancl get some Nica Crystal Grit and give them, as 1 knew slie was not giving them any grit. I advised her to put a little in the fond every morning. She did so and her turliegs are no louger fying. It was the absence of sharp grit that eansed them to die.

I have adopted a treatment for turkeys and chicks that has proved a great success. If I see them arot as though they were not feeling well I give a calomel pill.
These I buy from the druggist, eaeh pill to contain a tenth of a grain of calomel. I give the pills one a day for three days, then follow with quinine pills twice a day until the hirds are well. If noticed and treated when first they show symntoms of not being well I have never failed to effeet a cule. The calomel stirs up the liver and gets it to work, as most cases of sicliness among poultry commence with a disorlered Jiver. After the system has had a thorough eleansing the quinine aets as tonic to bnild the birds up and gives them appetites, then nature does the rest. By this course of treatment you ward off what might terminate in serious sickness and death. I have used similar treatment in the human family and saved a great many doctor's bills, to say nothing of long spells of sickness and sullering.

\section{OVERFEEDING CAISES DEATH}

Orerfeeding is a common cause of loss in young turkeys. I feed cnly three times a day for the good reason that I could not possibly find time to feed oftener with the large number I raise. I find it suffieient. They take nore exercise if fed less, then when they are fed they are hungry. The time between feeding, too, allows the food to digest and gires the digestive organs a little rest.

I feed more green food than most people do, as I find it has the same effect on turkeys that it has on ducks. It produces a large frame. I chop dandelion leares for them in the morning and at night chop up onions, tops and all. L notiee there is never a scrap of the green food left when they are through eating. They make rapid growth when fed this way, besides it is a eheap way to feed them.

I give a little sharp grit in their food erery morning. I use grit and oyster shell, the larger part grit, as turkeys to be healthy must have it. I have lost humdreds of turkeys I lnow by not having plenty of grit with which to grind thejr food. If they get a little sharp grit in their food every morning it keeps their grinding ap. paratus in perfect order. Very ronug birds do not find the grit of their own accord, and as they grow older they are liable to gorge themselves with the grit as soon as they discover it, thereby elogging their digestive orgaus, while a small quantity in their food each morning keeps them in excellent condition.

I have my little poults so they will fly over a board a foot high when but one week old. There are more turkeys killed ly over feeding and lice and want of grit than all other things combined. If you do not keep them near the house so that you can run them under cover when a heavy storm comes up you are liable to lose a large per eent. I find a large shed with a board floor is fine to run them in in ease of sudden storms. Of course you must stay close at home to meet all these emergencies. It is not more contining than other oecupations. The merchant, lawyer, loctor, mechanic and farmer have to confine themselves closely to busiuess. and the poultry raiser, whether for the fancy or market, must make it a business and work on business prineiples.

\section{EVILS FlRON LAK OF EAERCISE}

I learned something about exercise for very young turkeys this year. I latehed some under hens quite early; it was wet and cold and of the two evils I decided 1 would not tirn them out to run through the day, so I kept them corped a week or more. When I went to feed them I found one that did not seem to have the use of its left side. J thouglit it had got hurt in some way and wonld soon be all riglit. It got no better and I still kept them eooped, as it was so cold and wet: then another got that way. 'They would push themselves around with 
their right foot as they lay on their left siste. When the third one was taken sick $\mathbf{I}$ deeirled it was paralysis of the left sirle, bronght on by lacli of texereise, ant so I turned them out. Those that has been atiected died. It was still cold and wet when my other turkeys began to lateh, and I kept the first lot of chicks eooped perhaps five days, when one of them acted in the same way as the early hatcherl birds. I turned them out to run through the day and that was the last of it. This convineed me that it was paralysis brought on by lack of exercise. The peculiar part of it was that it was always the left side affected. My turkeys are making rapicl growth out on the range. I feed them a little grain when they come up at night, and we lave such quantities of apples that I put the small ones in a box and chop them up with the spade and feed them to all the poultry, and they do enjoy the cool juice these hot, dry days, and the apples keep them in such good health and are so much better for them than green food or even grassh'pplers exclusively.

The only road to success with turkeys is to keep them healthy. Give then plenty of exercise, commeneing to let them run through the midlle of the day at three or four days old; keep the lice off and give a little grit in their food every morning, with good, elean water to drink and they will have very few diseases. Excreise they must have, but very roung turkeys can have sufficient exarcise on an acre or two, and a great many young turkeys (an he sured by enjoying this exereise under your control. (oor) at night until they begin to want to roost.

\section{PUNCHING TIIE POULTS}

I always mark my young poults when I put them out on the range, as otherwise they would be forgotten or neglected. With carc there will be found web enough to allow a good marls and it will not grow together if, as sometimes is the case, you cut into the edge of the web, It will do no harm and will alray's show the mark. It is different with ducks, the mark will grow together if marle in the edge of the web, but if sereral punch marks are made yon can always see the scars, as the webs of their fcet ale very transparent. Sometimes I make so large a hole in a duck's foot that it does not grow together and I often find them with a weed run through the hole. In their efforts to release themselves they get twisted and lang there until they die if not released.

\section{PLLLANG WINA FEATIERS}

1 : In alsed if I pull the wing feather's of sick poults to improse their kealth, and I reply-No, not to improve their health, but to prevent too mueh strength being takeu from their systems by the extrene growth of flight featliers. I usually pull the first tlight feathers on the wing when the turkeys are from three to six days old, as it that time they come ont so easily that it almost seems as if nature intended those feathers to be pulled. Sometimes I cannot get the time to attend to it, and I notice the quill feathers are maling sucl rapid growth that they hang down, almost drag, and the turkeys appear much weaker than those that have had their feathers pulled; after this jeriod, too, they are much liarder to pull and the poults hare lost all the strength that it bok to grow them. They should be pulled almost as soon as they start to grow, then your turkeys will put glowth into the body and the other feathers.

This [recitly increases our chance of suceess.

A thought rais sugrested at one of the Chicago shows. Dues the sccond growth of flight feathers"malio as finely markerl a wing as the first, or is the reverse the tase? I had never thought of it in that light before and shall cxperiment this summer and let the readers know. 'l'his much I do know after year's of experience, the little turkers certainly are strunger and stand a better chance of living if the first flight featlers are pulled when they ale from three to four days old, and they come out so easily at this time that it has no evil effect.

\section{IICE INII MITE UESTROVERT}

Anotler correspontent aslied about carbolineum, 
painting perches I prefer the carbolinenm, but I like the lice killer best for painting a box in which to place the lirds. I use lice powder for the very young birds.

\section{SONE DISEASES OF TLRKEYS}

$\Lambda$ lady wrote that she hatched sixty-six little turkeys and had only ten left. Her turleys had a diarrhoea, a thin yellowish discharge. This might be from lack of grit.

$A$ s the cold rains and cool nights come, colds that take the form of roup often attack turkeys, though I have very little if any trouble of this kind since I learned morc about turkeys and their ways and since I feed them just clear, dry grain. When 1 used to feed mashes often hot or very warm, both chickens and turkeys had roup, but now it is almost an unknown disease on our place.

I saw a remedy recommended which I think worth trying. It was to bathe the swollen head, mouth and throat with turpentine. It is said to work a speedy cure.

A lady telephoned me recently that one of her hens was suffering from a peculiar trouble. Although it had a good appetite it could not get its head to the ground to eat. The trouble appeared to be in her neck. I advised rubbing her neck with turpentine and putting her food up high where she could reach it, and thought she would get over it as she appeared to be very hungry, which proved that her digestion was all right. A few days later the lady reporter tliat the hen was all right.

Several cases have been reported to me in this vicinjty, of sick turkeys whose droppings are yellow. I have recommended linseed oil, or what has proved much better, olive oil. A lemon extract bottle of the smaller size holds about three doses. It should he given about twelve hours apart, and ahout six hours after the last dose of the olive oi] gire a capsule of quinine. Give quinine twice a day until the turkey has regained its strength. Quinine is a very strong tonic for turkeys, and I am never without it. But never doctor poultry if it can be avoided, as poultry, like people, are better kept well than doped to make them well. They, like ourselves, are machines. If they have the kind of food nature intended them to liave and they have exercise to grind that fo.d, it goes to build up the system and to repair the waste that is constantly taking place. We must all exercise the muscles that do the grinding.

The Bible says that man must earn his bread by the sweat of his biow. Working until the sweat shows on the brow means hard physical Jabor and that promotes health. Of course we have thousands of men today who have the get-rich-quick idea in their heads, who are determined to avoid earning their bread by the sweat of their brows. The result is that our prisons are full and thousands of men are broken in heaJth. Let us Jearn a lesson from our birds and be wise. Animals of all kinds eat and exercise to digest their food, but man alone covets ease and luxury without physical labor. We always have among us men broken down in health and in mind who fill early graves because they are not willing to submit to nature's ways and so retain their vigor and lealth.

\section{TINCTURE OF IODINE FOR LICE}

I have been in the habit of using tincture of iodine - for lice. I take a feather (but intend getting a small brush) and brush the top of the head and across the quills of the wing feathers, under the wings, and the fluff below the vent with the tincture of jodine. It is a fact that $I$ have proved time and again that those treated with iodine for lice ontgrew those treated with other remedies, the only objection being the expense, but if one will send and get a large bottle at wholesale price it will not be expensive.

When turkeys are malking very rapid growth, I find the lice arc making rapid growth also. When I take the old turkey off the nest I paint a box with lice killer, put her in and leave her for two hours. I do not shut her in an air tight compartment, only close enough for the lice killer to thoroughly fumigate her feathers. 'This kils all the lice and nits. I grease the heads of the little turlieys to lestroy the large head lice; I also dust them thorouglily with a good lice powder and paint their coops with carbolinenm, but with all the precautions $I$ find 1 must look orer them once a rveek for lice. One of the most essential things during July is to Jreep the turkeys free from lice.

The first of July generally ends the turlkey egg business. Occasionally turkeys lay a third clutch of eggs after that time, but $I$ never consider them of much value, as they do not hatch well and the young turkeys never grow very large. I remember one exception to that rule. I had a brood of young turkeys come off about the first of August, and a pullet from that flock weighed sixteen pounds on the 10th of December. I took first premium with her at Dixon, Ill., before the weight was raised in the Standard. That was one pound above standard weight on a pullet ten days over four months old.

The work for August in the turkey yard is very light as the turkeys are, or should be, out on the range on farms. I only feed them a little in the morning so that they may be induced to run out in search of food, and a little at night to get them to come home. After they have started out, all I have to do is to bring them home at night and keep on the watch for lice. They go through a corn field and I have noticed the old turkey and young ones stop and wallow in the loose aurt to dust them. selves, so I hardly ever have much trouble with lice when they are out on the range.

In November I have watched them with a great deal of interest to see how they make up their bill of fare for breakfast. They work lively, for they have voracious appetites and have nearly cleared the place of grasshoppers. Now they make their breakfast of weeds or grass seeds with occasionally oats that have been left lying on the ground. I notice as the fall advances they spend a lot of time in the corn ficld, picking corn from ears that have been blown down.

The following is a good story, although I do not rouch for its truthfulness: $A$ farmer in Kansas has started a novel plan, based upon the prevalence of grasshoppers. He has about one thousand turkeys. After his neighbors saw the way his fields were cleared of grasshoppers they proposed hiring one hundred turkeys by the day to eat their grasshoppers, so he divided them into flocks of cue hundred and hired them out at $\$ 2.50$ per one hundred for a day's work, which made $\$ 25$ income a day for the use of one thousand turkeys, and what turkeys those turkeys will be this fall. This of course settles the grasshopper question in Fansas and Nebraska. If they can settle the rainfall question as easily, the two states will never hold the emigration that will rush there.

\section{INBREEDIVG AND NEED OF RANGE}

Turkeys deteriorate quicker by inbreeding than any other animal. Inbreeding indiseriminately for a long time weakens their constitutions. Turkeys, like horses, in their wild state, elected their leaders, or rather the leaders elected themselves by their prowess. When an old leader began to show signs of feebleness a young 
turkey tom challenged him to mortal combat. If the old chief was equal to the combat the young aspirant was compelled to fall back to the rear or remain where he fell. When the old chief showed renewed signs of feebleness another young aspirant for royal honors stepped out of the ranks and the old tom rarely came off conqueror. One of our hunters who goes west every year to hunt has often told me of seeing the footprints of an enormons wild turkey that he had tracked and had occasionally got a glimpse of. He described him as being as large as a calf. That old tom lad evidently ruled supreme for many years and had grown too smart to be

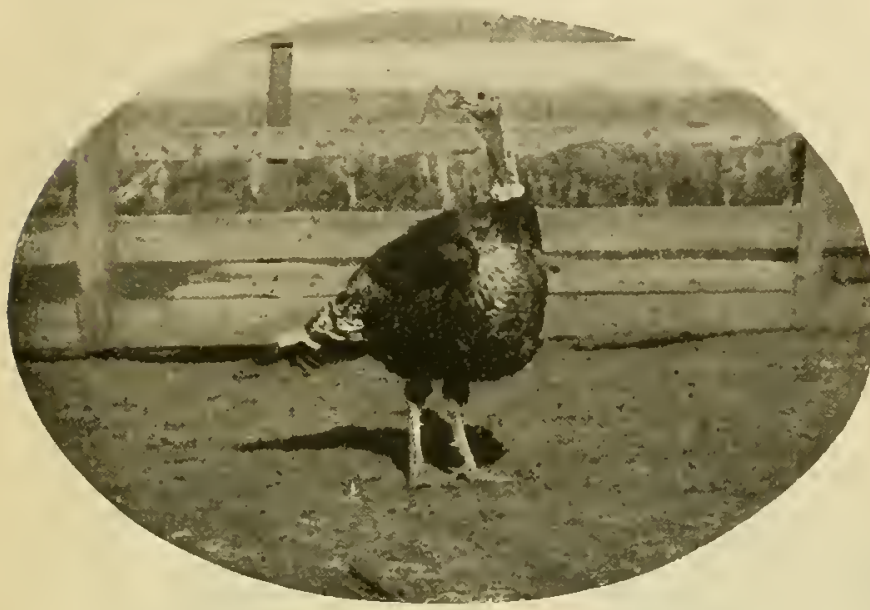

A Winner from the Yards of Mrs. Chas. Jones

caught napping, so the hunter could never get a shot at him. Turkeys in their wild state range in large flocks, but when they are domesticated it is necessary to keep them in small flocks. I think eighty acres little enough range for 150 turkeys. They could be bred in and left to run in flocks of three hundred if they had a range of three lundred acres. The reason large flocks cannot be kept on small range is that they do not find sufficient insects and the thonsand other things that they pick up to make their bill of fare. Fifty can be kept on from one to three acres until they are six weeks or two months old, then one just simply cannot keep them in a small enclosure, as they will erawl under or through or get out some other way, for they are growing fast and must have what nature demands. I always make a virtue of necessity and turn them out on the range.

I change males every year. I do not go ont of the strain I am breeding, but take another branch of the same line of bloorl, and have found that I do not impair their rigor in the least, but am building up strong, healthy birds with plumage that for years has kept my whole flock above a score of 93 , and that in a flock of one hundred and fifty birds. Last year 94 was the lowest. While I have inproved them in shape and plumage I do not find one sick turkey in twenty-five throughout the season.

\section{LINE IBREEDING}

At one of the great Chicago shows two things were very strongly impressed on my mind; one was strain or line-breeding of turkeys. The two leading strains exlibited there have been line bred to my certain knowledge; one at least ten or twelve years (perbaps longer, but I am speaking of what I know), the other from information gained in different ways $I$ an led to believe has been line lred the same length of time. They have formed two distinct types; both strains very large birds and beautifully bronzed, but with this difference in color of plumage-in one strain the bronze or gold band across tail coverts, and in fact throughout the whole plumage was a greenish golden color; in the other it was just the color of gold without the greenish hue. From what I know these two strains have won most of the premiums in our leading shows from Madison Square to Chicago. Upon comparing the plumage after the premiums were awarded the exhibitors were convineed that the birds represented two distinct species of the same bird. The strain that had the pure gold color had the gold band the entire length of the back. This was absent in the other strain.

The prevailing idea in looking over this Chicago show was that the old avoirdupois way of mixing blood was out of date, and if we expect to get to the front, the blood must be weighed by apothecary weight, or better. still, on the alchcmist's scales, although the alchemist, I believe, has never been able to brew in his caldron ingredients that turned out gold. One hreeder proved beyond a doubt that he could put a clear, even gold band on Bronze turkcy's, and the inference is that he has been for years using the alchemist scales to reach this much to be desired point of excellence.

If the exhibits of lronze turkeys continue to grow 1 am afraid there will have to be erected a new Coliseum for the turkey exhibit alone.

If we all hred Plymouth Roeks and there was only one hreed and one club, the poultry business would be tame and we would lose our incentive to strive for our ideal in the variety that met our fancy. Now if the admirers and hreeders of each variety of turkeys were to organize a club to push the interest of their particular breed, to look up their origin and write up the good qualities that commend them to breeders the turkey business would be pushed to the front in a way that could not be accomplished by an indiscriminate pushing of all varieties combined.

\section{TURKEYS VS. GRASSHOPPERS}

In looking over a Chicago paper some time ago. I saw an account of a liansas farmer who was starling turkey raising on a large scale. His idea was a good one as they are raising large fields of alfalfa and the grasshoppers are proving a great detriment to that crop. Alfalfa has been a great boon to the drought-stricken parts of our country. Irrigation, the raising of trees and then the great crops of alfalfa have made the desert blossom like the rose. But the grasshopper lays its eggs, and the young when liatched feed on this alfalfa, the best paying crop of these districts. They eat off the blossoms and so make the raising of seed very difficult as the second crop is the seed crop that is saved, and that is the very crop that is ready when the grasshopper season is at its height. The seed is valuable. We paid vine dollars a bushel for enough to sow three acres.

I have always thought that if Kausas farmers would go into turkey raising on a large scale, they would do away with the grasshopler plague to a great extent. I liave watched fields where grasshoppers were thickest and $I$ found that as a rule they are not migratory in their habits. I know that in the early days of the settlement of Kansas and Nebraska they were said to go in swarms, but here when they are thick in one field one year they are usually thick in the same field the following year. Along the railroad they are thick every yeir, because nothing is allowed to go on the track for fear of it being lilled. And so they lay their eggs there and they hatch and the young thrive, and this is repeated 
year after year while in adjoining fields there are cummatively few grasshopjers.

If each liansas and Nebraska farmer would raist from one to lwo hundred turkeys each year he would find his farms cleared of grasshoppers, and the weel seeds that are so great a detriment to farming woulc go into the crojs of the turleys and what had been an injury to iarmers vould be turned into many do\}]lars for their use.

I have been told that the alfalfa in western Nebraska was full of grasshoppers when cut, and that they smothered. During the winter the chickens scrateh preserved grasshoppers ont of the hay. Turkeys would fint there their natural foot all cut and dried for them, except the exercise of scratehing to get it. lt is a good story and it has an advantage wer some told of that country, for this one might be true.

No one need be afraid of overproduction of turkeys is the demand will always exceed the supply. In the states where both alfalfa and grasshoppers grow, farmers will raise three crops in one-the hay for the stack and the grasshoppers for the turkeys. And so the states that have had sis harl a struggle to produce paying crops year atro year. ma ret become the greatest money making states in the union as they are also in the great corn brlt. Look baek across the years when the first Thankswiving turkeys were killed to feed the staring l'ilgrims and note the marvelous changes that have taken place. "The greatest nation on earth was born and kejt from starvation by wild turkeys and wild game with the meagre supplies sent across the ocean by slow sailing vessels that took months to reach our shores. If ever in the futme our supply of turkeys shonld exceed the demand, our fast going steamships will take them to foreign markets in six to eight days where there will be an unlimited demand for anything so delicious to the taste as a properly grown turkey.

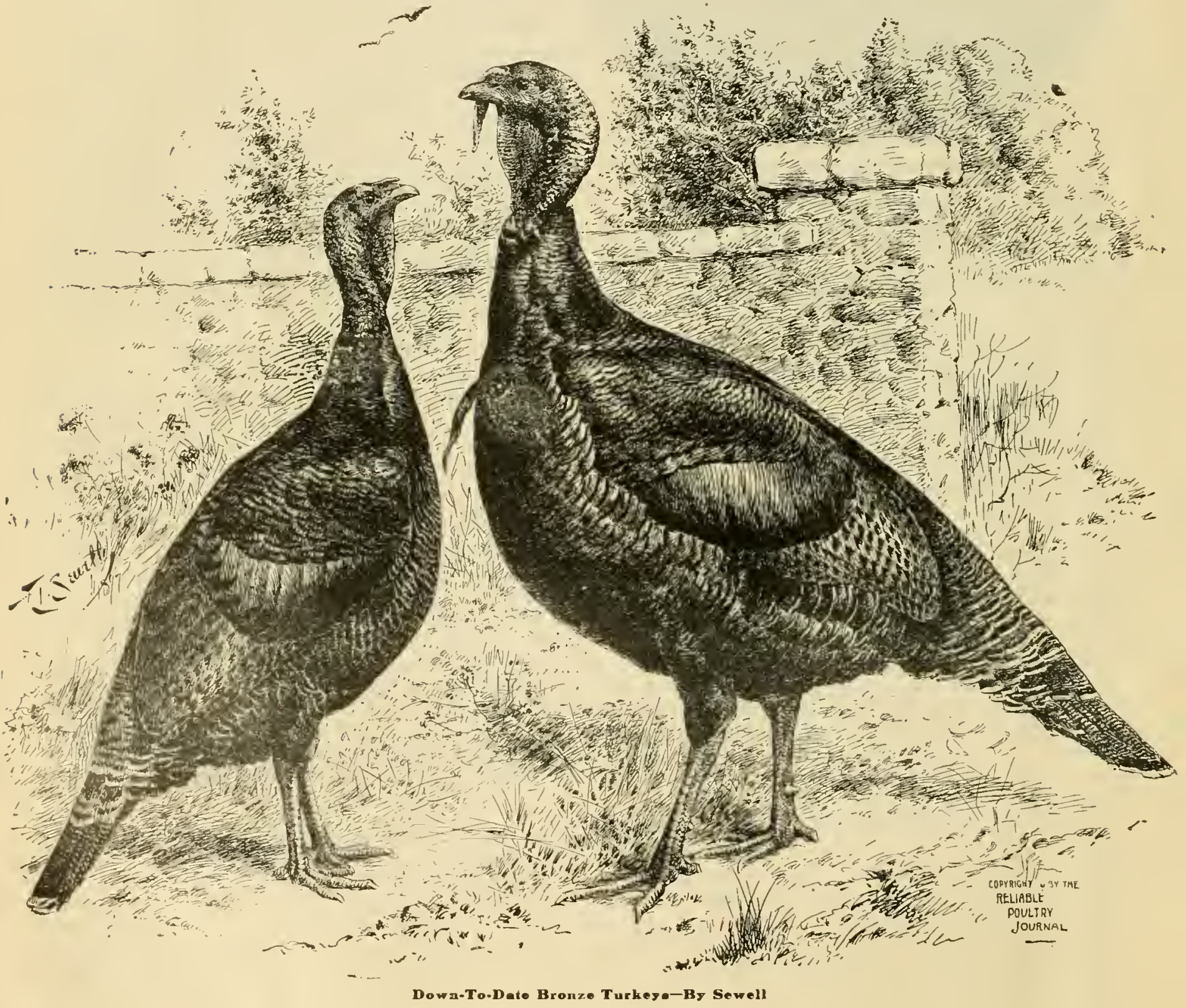




\title{
THE WATCHWORD OF SUCCESS
}

\author{
Experience, Watchfulness and Common-Sense are Necessary to Raise Prize-Winning Bronze Turkeys-Something About Coops for the \\ Mother and Her Poults-Do Not Overfeed
}

MIRS. NELLIE BULLOCK

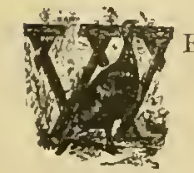

ERE I to begin the breeding of fancy turkeys and conld hare the benefit of my present knowledge, I think I should buy stock, the rery best my purse wonld allow, even if I had to limit my flock to a pair. IVe bought egrgs at different times from three noted fanciers, but something went wrong each time, either the eggs were infertile, or not strong enough to hateh, or the poults would manage to die. So I think the quicker way to sccure a good flock wonld be to purchase birds. Turkeys are hardy after they are half grown, and most persons would sell cheaper then than after they are grown. It would not be a bad idea to invest in half-grown birds.

I should advise any one who has not raised turkeys to get the cheaper grade of some thoroughbred variety you faney, and learn with them. Then if you have losses it will not bankrupt you, and when you have mastered the details necessary to raising these successfully jou cat invest in birds of fine plumage and other fine points possessed by fancy fowls, to the extent of your much enlarged purse-nerer forgetting, howerer, that there is always something to be learned.

For those who have had success in raising commol: turkeys and who wish to start with some special variety of thoroughbred turkeys, I shonld advise them to get a pair, trio or pen of the best your purse will afford and apply to them your knowledge of care and feeding gained while raising the common birds.

\section{CARE OH l'OHITS}

Raising the poults is the hard task for most beginners, and some of the more experienced ones have their hands full when they try to raise a large per cent. Practical experience, watchfulness and plenty of common sense applied to the varying circumstances, are necessary to success. Our plan is somewhat as follows: First, we require a roomy coop with a dry floor, covered with timothy or elover chaff. Confine the mother, either a chicken or a turkey hen, on rainy days. On dry, sunshiny days, tether her to an apple tree limb, having the coop near. Clean the floor twice a week at least. If the earth is dry, it will serve very vell as a floor, otherwise, a raised board floor would be better. Dust both the mother and the poults thoroughly twice a week with Persian insect powder. For dusting the poults, I keep a two gallon, flaring carthenware crock. We put a handful of powder in the erock, then hold the poult by the feet over the crock and dnst it until it looks yellow all over. J do not have so much trouble with lice as I did when I put the powder on in spots. Keep the water dishes clean and full.

We try not to overfced. and neither do we starve them, for one is as bad as the other. We console ourselves if occasionally a poult dies, or several of them die at onc time, with the thonght that our neighbors, too, lose poults and that very few, no matter how much knowledgc they have on this subject, can raise all that hatch."

\section{TURKEYS AS IIATClIERS}

There was an interesting item in the Reliable Poultry Journal some years ago orer the initials C. H. A., which we reproduce:
"A great deal is being said lately about using turkeys for hatching hen eggs, so I will give iny experience. It lhas been really comical to see the look of dombt on the faces of people when told that we had turkeys which had never laid any eggs, sitting. Too polite to dispute the statement, their looks plainly said, 'Does he expect me to believe that story?'

"When I first read in an English poultry book of the French method of using turkeys to hatch and care for chickens, I lad no ineubator and concluded to try the plan. Late in the fall I sent out in the country and bought a late hatched hen turkey for very little money. In February we prepared a box (with plenty of chaff over a layer or horse manure) that could be shut up to exclude the light. Did not give either wine or whisky, but in $t w y$ or three weeks she was sitting quietly on the china eggs and when talien off the nest to be fed. would roluntarily return. I then filled the nest with hens' eggs, remoring them as soon as they began to pip to keep the turkey from wanting to leave the nest and putting in other eggs. After sitting three months she was put in a yard with ehickens for the rest of the summer. IVe put ehickens of different ages with her and she received them all with equal kindness.

"This year we have two turkeys, besides an incubator, and after hatching three sittings of egg's we thought best to take them off the nest, but one watched her chance and went back on the nest till I filled it with eggs agrin, so $I$ let her stay. The other is laying and will be ready for work later if needed.

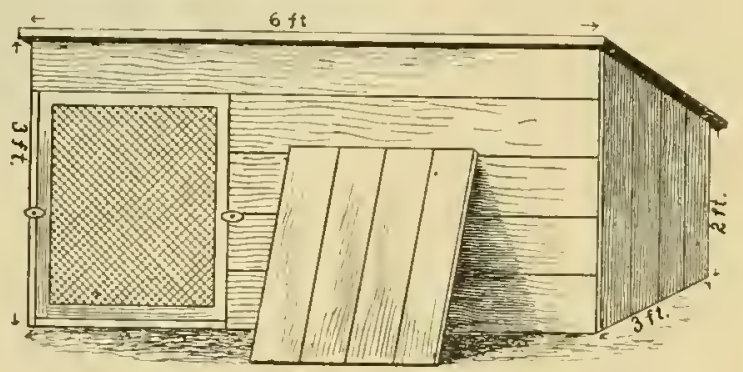

Ideal Turkey Coop for Hen and Pouls

"They make careful, patient mothers, are equal in that respect to any hen, and it is a wonder that farmers do not make more use of them than they do."

\section{DESCRIPTION OI' IDEAL (OOI'}

We have a coop for turkeys and poults which we find almost ideal. It is two feet high in the back and three feet in front; six feet long and three feet wide. The door is large enough to allow a turliey hen to walk in and out without inconvenience and the coop is large enough to allow a turkey hen and twenty poults to walls around when they are confined during a rainy day. We use two doors, one made of lumber for stormy times, the other of inch mesh wire netting for warm nights. Thus plenty of fresh air is admitted and small rats or larger animals are kept out. 


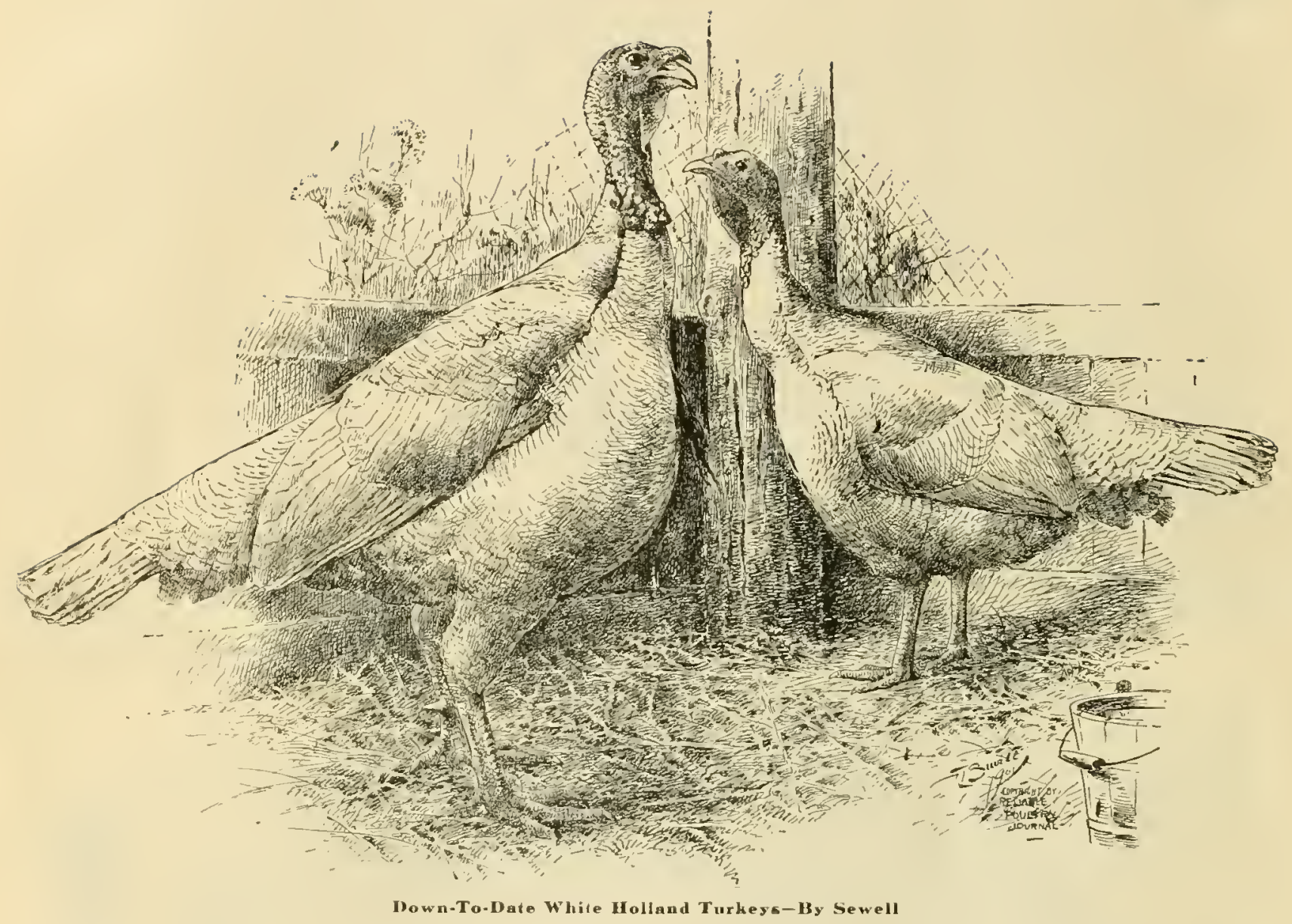




\title{
WHITE HOLLAND TURKEYS
}

\author{
Beautiful in Shape and Chaste in Color, They Form an Excellent Foil for the Brilliant Hues of the Bronze Variety, While Their Many \\ Excellent Qualities Make Them Worthy Rivals
}

\section{JOHN R. GARBEE}

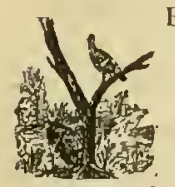
and we counted ourselves among the lucky ones if we, or rather I should say the old turkey hens, raised sixteen or twenty a year. If the young turkeys weighed when dressed in November eight or ten pounds they had done well. fever." I have been a reader of the Relial)le Poultry Journal ever since it came into existence. I have a complete file of it down to date, which fact is explained when I say

I also lead other poultry and farm papers, and soon I was convinced that better poultry and turkeys ought to be raised on farms and that turkeys could be managed so that there should be a good profit in them. Hunters were killing our common turkeys for wild ones because they wandered so far from home, thereby causing us considerable vexation and loss.

We had never seen a pure white turkey, but we read about their. gentleness and that they did not roam like the other varieties. So we sold all our common ones and purchased a trio of White Holland turkeys from an R.

A flook of White Hollands The Property of Mr. John R. Garbee
EAlis ago we raised only the common turkeys Alung about 1890 I deveioped a severe case of "poultry that I consider it the leader among pouttry papers.

hen) or are put in an incubator. We get successful hatches either way, but we never have had success when we put the poults in a brooder. It may be the fault of this particular make of brooder, as I never have thought well of it, though it is a high priced one. So we give the poults to hens. Now, it is easy enough to hatch the poults, the main trouble is to raise them. I am free to confess I do not know it all, but some things I have learned from experience. I know I have lost more poults from lice, over feeding and chilling than from all other causes combined. Lice are the poults' worst enemies, and next they suffer from overfeeding. Our rule for feeding clicks is "any sound, wholesome food, fed a little at a time." 'l'his rule applied to poults worlss equally well. We are most successful when the weather is fair and the food is given to them three times a day, and not faster than it could be digested. We find cottage cheese is good for them and they like it, but judgment must be used in feeding it. I repeat that any clean, wholesome food fed in moderation is good for them. We find a varied diet-corn bread, cracked corn, wheat, chopped vegetables, table scraps, even corn dough ocP. J. advertiser, paying $\$ 7.50$ for them and $\$ 2$ expressage - which seemed a big price then. Since then we have paid more than that for a single bird. These first birds were rather small, though pretty. Up to this time I never had seen a standard, but I soon bought one and learned that my birds were under weight, and feed them how I would, I could not get that trio up to Standard weight.

I soon learned where I could get large white Holland turkeys, and I bought some more, still keeping the little, plump hens. The next season the young poults were larger than their mothers-the result of using a large tom. 'The results have been about the same whether I used a large young tom or an older bird, provided the young males were big boned, blocky fellows mated to good blocky hens or pullets. Still, I preter a tom from two to fire years old. I wish to state here that when 1 began breeding this variety of turkeys the toms at their best weighed only sixteen pounds and the pullets and hens eight to ten pounds, but during the past three or four years, by following iny own rules of mating as given here, my turkeys have doubled these weights, so that now my young toms and pullets weigh from fifteen to twenty-four pounds.

I use hoth pullets and hens as breeders, though I am careful to select the best shaped ones-those that are blocky and in first class health. The first eggs that are laid are given to domestic hens (eight or ten to each casionally-works all right, while some breeders claim success on one straight diet.

After the second and third clutches of eggs are laid we set the turkey hens. We always prefer to move them to a suitable coop or barrel nest in the yard or near a poultry house, so they can be protected and cared for better. They can be moved with but little trouble when broody. They are confined to the nest for a few days by a slat coop, after that they get off and on at will, food and fresh water being kept near them. Remember always that lice are the great drawback to suceessful turkey raising, and try to have your sitting hen absolutely free from lice, mites or jiggers when the eggs hatch, and then keep her free. Watch the poults, too, and do not let them suffer from lice. $A$ clean coop and pure water are essential to success.

Do not overfeed nor underfeed either. Provide a comfortable place for the hen and poults, so that the latter may not get unduly chilled, and give the heu all the fond she will eat, so she will not be restless, but put her food out of reach of the poults. Note how the latter will grow with this eare. By the time they are feathered and large enough to roam they will be but little care and they will get a large share of their food trom the fields, but if you follow the method I have ontlined they will always come home for supper and will be very gentic. 


\section{ADVOCATES WHITE HOLLAND TURKEYS}

Their Beauty and Market Qualifications Make it Bath Pleasant and Profitable to Raise Them-Preferred Weight of Turkeys-InbreedingBlack Ticking on Feathers

\section{A. LELAND}

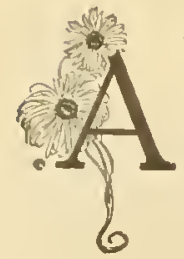

FTER several years of experience with White Holland 'Turkeys 1 have come to the conelusion that there is no better variety for beauty and utility. The standard weight for adult toms is twenty-eight pounds, for adult hens eighteen pounds, for young toms twenty pounds, and young hens fourteen pounds. These weights are often exeecled. but not as a lule to the adrantage of the breed, although turkeys are never housed, nor should they be, except for convenience in handling. but we consider it best to have them roost some place sheltered from serere winds and storms.

I would ehp the flight feathers of one wing so that an ordinary five-foot fence that they could not get through nor under, wonld eonfine them.

We would not consicle it profitable to raise large numbers of turlieys in small enclosures as they require

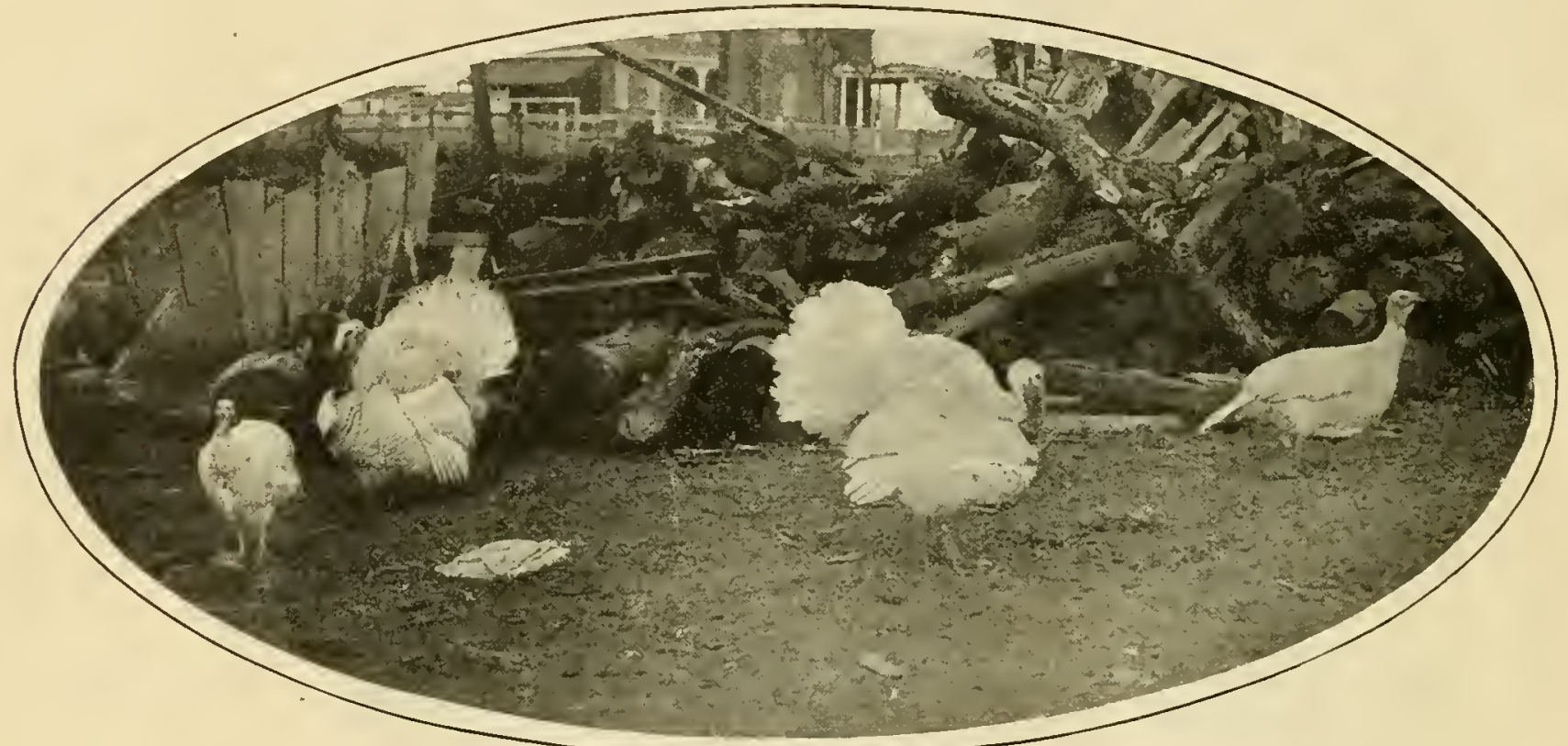

White Hollands, as bred by Mr. J. A. Leland

the majority of fanciers try to produce the lieaviest birds possible for show purposes. In our experience young stock nust reach these weights when abont six to eight months old if they erer attain standard weight when mature. Very heavy specimens are not prolific breeders and stock weighing standard in breeding condition is generally to be preferred.

Inbreeling is a thing that turkeys canmot stand, therefore, it is imperative that new hlood be obtained each year if we wish to raise a large number of hardy, heary boned fuwls that will top either the market or show room. As to color I have nerer seen a White Holland turkey that did not show some black ticking in its plumage during some period of its life. However, there is a great difference in speeimens in this respect and we should breed from stock as free from this fanlt as possible, if we ever expect to correct it. We believe an ideal White llolland should have a very full, round body (an egg with large end forward gives a good idea), neck of good lengtl, rather long tail and pure white plumage. They should have stout legs, the shanks should be bright pink or flesh color, the former much to be preferred from a beauty standpoint, and rather large feet. My a large range, where they obtain the greater part of their food at no cost. If all food were bought the eost of production would be too great and turkeys do not thrive in close confinement.

Abont the midale of Marcli we place boxes and barleels for nests in out of the way places about the farm lmildings. The hons find them and soon begin to lay. If turlieys are not furnished suitable nests they are apt to choose them in places exposed to clows and vermin. A clow will watch a hen lalf a day to get an egg and generally finds the nest, while $I$ liave found hens dead on their nests, killed by minks or skunks. If their first clutch is taken away they will lay another and sometimes n third. The broody hens should be confiled a few days if their eggs are taken, as they sometimes will sit on their nests all the rest of the summer and may die while molting in the fall. It is often a good plan to set the first clutch under domestic hens, as the conditions in early spring are frequently unfavorable to outdoor incubation, and these hens are more easily handled in confinement. It is best to let the turkey hatch her second laying, as the third comes too late, if at all, and early hatched turkeys are most desirable. 


\section{BREEDERS AND POLLTY}

Ordinarily I mate six to twelve hens with a tom and find the eggs are very fertile, but I think that as many as twenty might safely be mated to one male. Only one ton should run with the flock cluring the breeding season, but it is well to keej an extra one to use in case of acciclent.

My breeders have the run of the farm and get only what they pick up abont the buildings, which amounts to considerable in winter, but to almost none when good weather eomes and then they glean the bulk of their food iu the fields. 'Turkey eggs are very fertile and hatch in twenty-eight days. At hatching time the hen should be closely watched and, if necessary, the poults talien away whel dry until all are batched, in order that she shall not leave the nest with them and so chill the othel. eggs.

During incubation and at hatching time the hen should be frequently dusted with some good insect powder, so you may be sure she is free from lice, which, with filth and dampness, are the worst enemies of young fowls. Should this be neglected and the poults become infested, a mixture of kerosene and lard-just a few drops of the former, as it is so strong, will usually rid them of the nuisance. Aplyly it aromd the heat, under the wings and about the vent.

After the poults are hatched place a coop with a good roof and slatted end over the hen. This will allow the poults to range about, but keeps the mother from tiring them out or leading them through the wet grass. When the dew has dried the hen may be given her liberty, but should be carefully watched and driven to her coop in the evening, or in ease of showers. These coops should be moved each day, so that the young will roost on clean ground. The first feed may consist of infertile eggs boiled hard and chopped fine, or a little craeked grainoats or wheat preferred. A mixture of eoarsely chopped or ground grains with a little millet sliould be fed until they are from four to six weeks old, when they will be able to eat whole grain. From now on, in goor weather, they will need only a little grain in the evening, which will serve to bring them home at night and keep them tame. They will get their food in the fields until frost comes, after that they should be fed all the corn they will eat to prepare them for market.

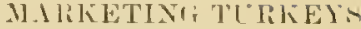

Young turkeys command good prices by the first of November or eren earlier in oul large cities, and all the heaviest, old and young turkeys, should be marketed between a few days before Thanksgiving and Christmas, because after that time heary stock is at a discount. Through .Tanuary the demand is usually only fair, but it is a good time to dispose of any lealy turkeys that were not in coudition to market earlier. Let us add right here that marketing thin poultry is throwing money away, as we miglat almost say that the lifference between thin amd

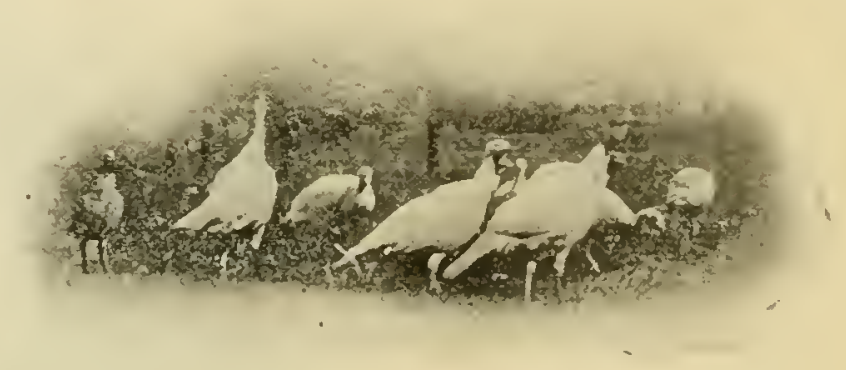
White Hollands at Woodside Farm, Mr. N. A. Leland

The two at the left are old birds, wianers of 1st prize as pair at the Illinois State Show. The others are young stock.

prime stuck is the profit. From March on the only demand is for medium to small turkeys, and that is when spring luens can be marketerl hest, fol they are then scarce and consequently bring a good price. It will pay well to dress them if the work is properly done.

As with other poultry, good, healthy stock must be used, it must have good care, be fed regularly and constant aftention must be given to every detail of the business. Given good stock and suitable surroundings suceess depends Jargely on the owner ol caretaker. Common sense must be relien ou to carry us over the hard places.

In closing I will say that $I$ believe there is no more hardy and profitable turkey than the White Holland. They meet all market requirements and their dressing qualities, flesh and beanty are unexcelled.

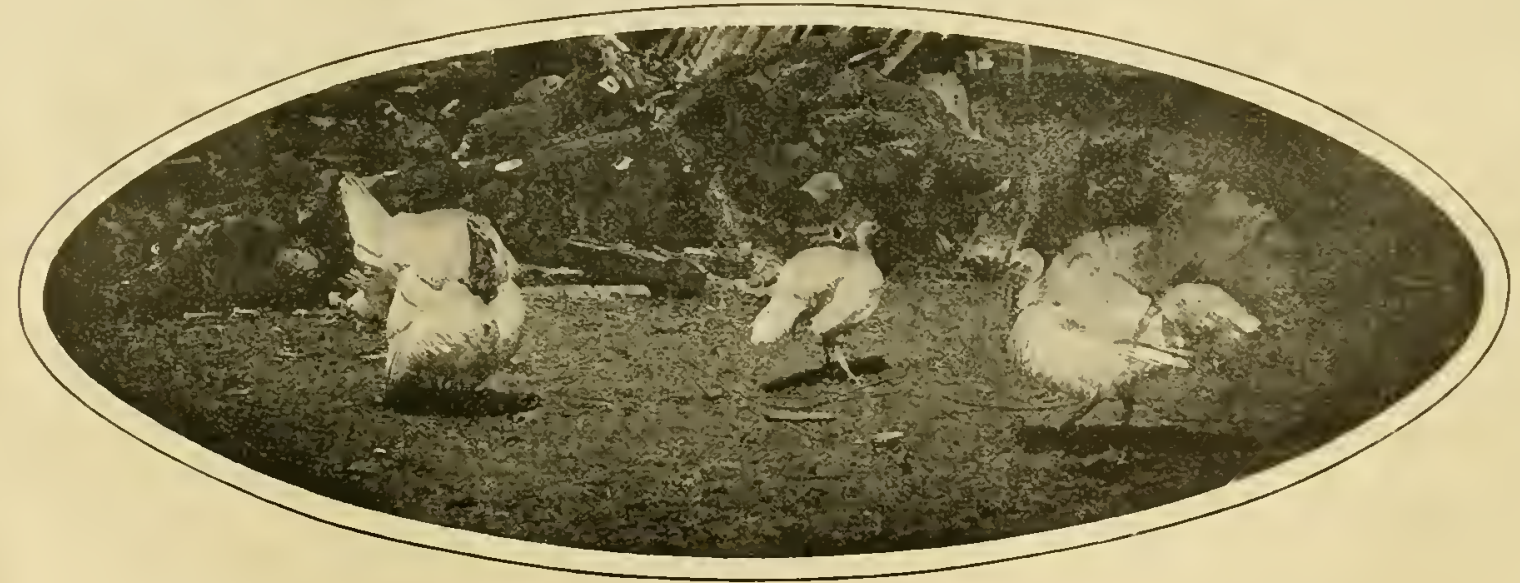




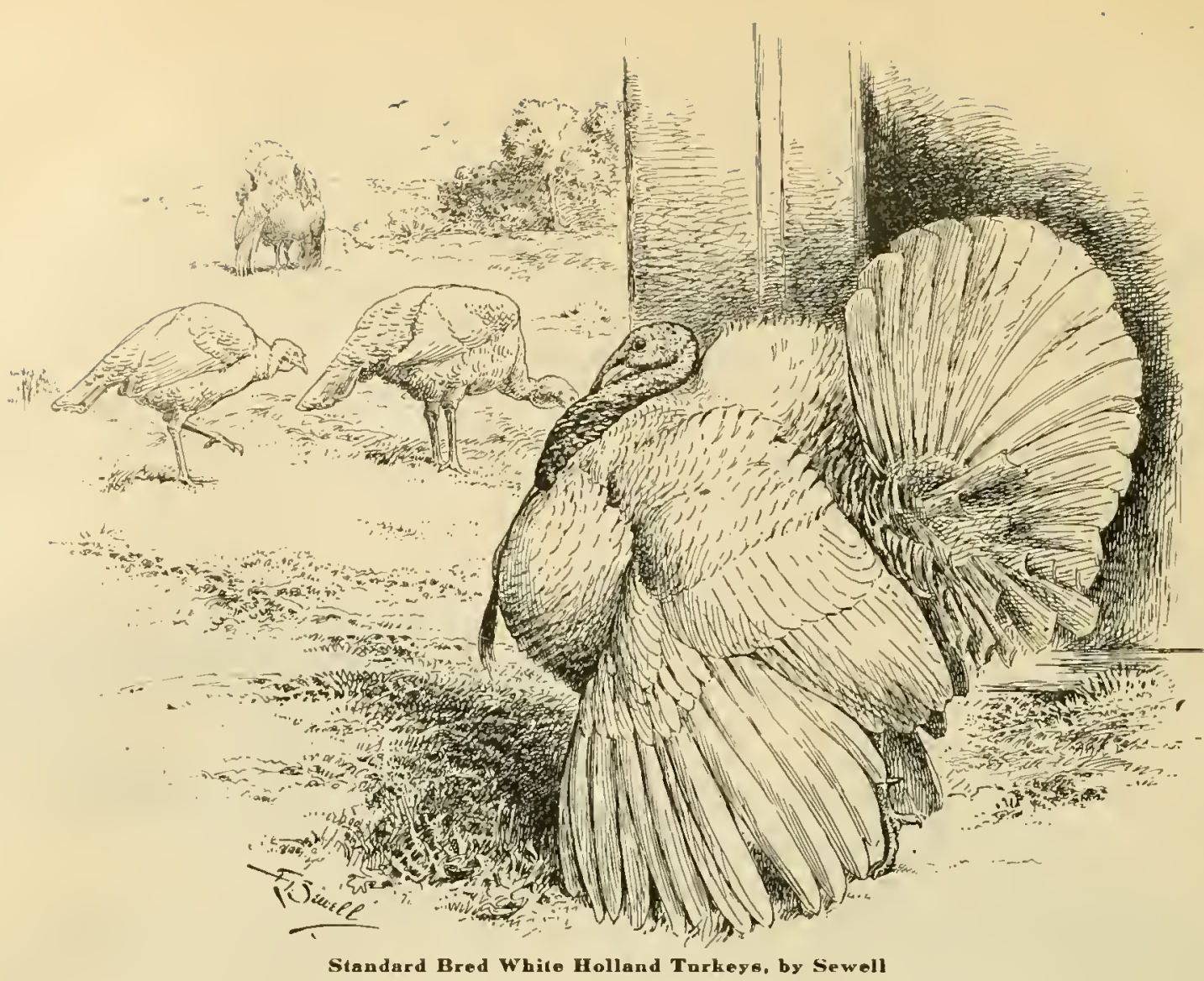

WHITE HOLLAND TURKEYS

\author{
Can bz Grown to Weights that Rival those of the Bronze Variety-May be Raised on a Small Place-A Clever Plan of Hatehing- \\ Feeding the Poults
}

\title{
A. E. BLAKER
}

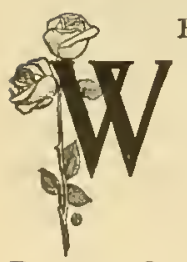

E HAVE handled White Holland Turkeys for many years and the longer we keep them the better we like them. They are the stay-at-home turkey and a large flock can be raised on a few acres of land. Those now bred by the leading breeders are rery closely approaching the weights of the Bronze. One of our head breeders for this season weighs over forty pounds, so I am inclined to think that those who have small birds only, have an inferior strain. Forty pounds is fourteen pounds abore standard weight, bnt it shows what can be accomplished by selection and breeding.

The White Hollands are the best layers of all the turkeys. They will lay all summer long if not allowed to sit. We have had them lay four clutches of eggs in a single season. Onr breeding Hocks are yarded and boxes and barrels are placed about in out-of-the-way places for nests and when a hen wants to sit we set her in those places. The fronts of these boxes and barrels are generally covered with brush and hay or straw put inside. We use about an acre of ground for the breeding flock, but one cau yard them in a very small place if necessary. We yarded a small flock one year, before we built our present yards, in a yard about five rods square and we never had eggs hatch better nor turkeys do better than llat spring. Out of 108 hatched we had eight accidentally killerl and raised 96 to maturity.

\section{UATCHING AND FEEDING}

We raise our turkeys altogetler with turkey hens, yet we have them to lay out their second clutch before we let them have the young ones. We started here in
Kansas six years ago with only two hens and a tom and the way we managed them is illustrative of what can be done with them. We sared up the eggs until the hens became broody. Then the eggs were set under chicken bens and we "broke up" the turkey hens. They began to lay again in about fire days and were ready to sit by the time the eggs hatched. Althongh they had been sitting but a few days they were ready to take the poults and mother them just as if they had gone the full time.

The poults hatch out very strong. Give us a few days of sunshine after they are hatched and we will bring nearly all of them through all right. We never feed the little ones corn chop, for we think it is too heary a food. The first feed is good sharp grit and we keep it before them all the time. The first few days we feed stale bread soaked in sweet milk and squeezed dry with the hands and plenty of green food such as dandelion, lettuce, onion tops or whatever we have handy. Boiled rice is an excellent food, so are boiled eggs, but I think one can feed too many boiled eggs and so cause liver trouble.

The poults are yarded for the first few weeks, but after we think they are old enough we turn them out and let them roam over the farm, being always careful that they come home every night. They require very little food and when grasshopper time comes they do not require any at all, but we always feed a little when they come in at night as an inducement to have them come home. They roam over the fields at their own sweet will in the day time, but they are made to understand from the start that they must come home and go in their yard every evening. 


\title{
BREEDING WHITE HOLLAND TURKEYS
}

\author{
Methods Used by a Successful Breeder-Selecting Breeding Stock-Preparation for Shows-Exhibiting-Diseases
}

\section{C, C. HERRON}

T PIESENT we are breeding White llolland Turkeys as we think they are the best turkey raised today. We have bred the Bronze, the Slate and the Bourbon Reds and have found the White IIollands to beat them all in many respects.

In our opinion, there is nothing as stylish as a well developed White Holland, with its pure white plumage, pink shanks and feet and bright, red head. They are of a very gentle disposition, make excellent mothers, will stand confinement better than any other variety we have tried and will mature quicker and lay more eggs.

They are the most tholoughly domesticated of any turkey raised today and by careful breeding the size has been improved until they today get to be as large as any turkey on the market. I have raised young toms that would weigh 24 pounds at Thanksgiving and never saw those weights beaten by any other breed or 'variety.

They can be successfully raised in confincment, the same as chickens, until they are able to take care of themselves and they will come home at night to roost, the same as a flock of chickens.

\section{BREEDING STOCK}

I am very careful in selecting my breeding stock. I select four to six yearling hens with long backs; broad, deep breasts, good plumage and all around shape. These I place with a

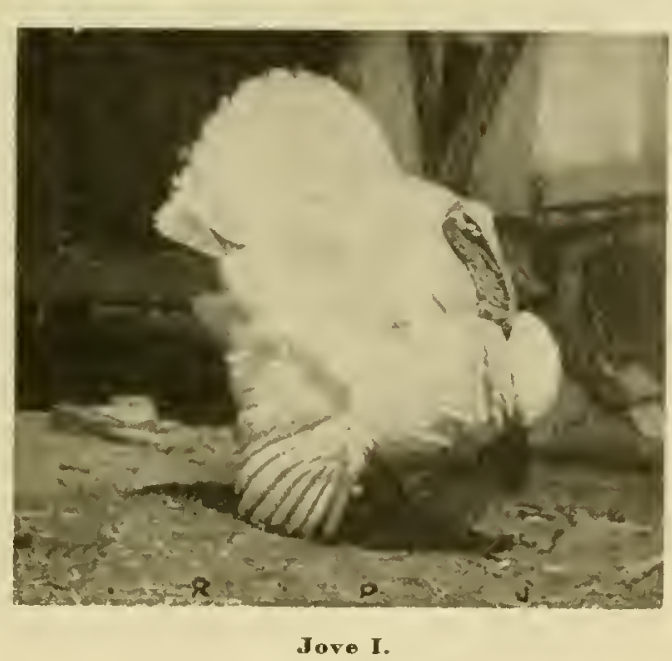

A forty-five pound White Holland Tom from the yards of the Royal Farms her free from lice. When the little poults are hatched, $I$ place them in a large roomy coop and let the ponlts have free range, after the dew is all gone in the morning. When they are three or four days old I give them a good dusting with lice powder and turn them and their mother loose upon free range.

\section{TIIE FARMER'S FRIEND}

There is no fowl that is as profitable for the farmer ac a flock of turkeys. They will destroy more insects than any other fowl and eat but very little grain until cold weather comes. Turkeys bring from $12 \mathrm{c}$ to $15 \mathrm{c}$ per pound in this section and wil] hring from $\$ 2$ to $\$ 3.00$ each, so there is a large profit to be made in breeding turkeys

\section{FANCY END IS NEGLECTED}

I think that the greatest tronble in the turkey industry is that they are neglected in the show room. They are not given near the attention that other poultry is, and for that reason they are not bred by more fanciers. I exhibit at some of the leading shows and as a rule the turkeys are placed in some back corner where they will not be seen by any one but the judge.

\section{CONDITIONING FOR THE sllows}

In July I start my old birds to moulting, then I put them up for about thirty days before they are ready to start. It is at this time that $I$ handle them and large, heavy-boned, vigorous, young tom, and I find this is the best mating I can get. I can get a larger per cent of fertile eggs and hatch ont large boned, vigorous, young poults and can raise almost every one. I think a large per cent of the loss is due to the parent stock.

I keep from five to six breeding yards each year and raise from two to three hundred. In the fall $I$ cull ont all the bad ones and place on the market about Thanksgiving time, and save none but the best to ship and breed from the coming season.

I aim to keep breeders that are show birds and at the same time are excellent breeders. When I find a good breeder, I keep it as long as it lives, for I think they never get too old.

I select my breeders and place them in a lot abont one acre in size, for each pen. I have a nest for each hen (a sugar barrel makes a good nest). Place the nest in a quiet place where they will not be bothered; it is best to conceal it a little and let the turkey think she is stealing her nest. I gather the eggs every evening and place them in a cool, dark place; turn each day after the first day, as they will keep longer when handled in this manner.

The first hens that want to sit, get the eggs. I place from fifteen to seventeen eggs under each hen and aim to set her on the ground, if possible. Be sure and keep get them tame and in condition. When they get so tame that I can handle them, I turn them out for a day or so and then place them back in confinement. This makes them very gentle and so I can handle them with ease, without their losing flesh, which they will do if kept shut up all the time. A turkey needs lots of exercise and will not stand steady confinement without losing in flesh.

I have my birds fully feathered and in good condition and as they have their new soat of feathers they are clean and ready for the show, except a few stains which can be easily removed with a damp cloth or sponge.

$$
\text { SHIPPING TO THE SHOW }
$$

I place them in a good tight crate with plenty of straw. This keeps them clean while on the road. Be careful not to leare any cracks in the crate; it is one of the rorst things you.can have to muss up the feathers, as the birds will be restless and move around more or less.

\section{DISTASES AND PREVENTATIVES}

'Turkeys are an easy fowl to raise, yet are subject to several diseases such as cholera, roup and black-head. While I am never bothered much with any of the above diseases, I think they can be prevented by keeping your birds healthy, with roosting places in the open air, alsn by using clean food and fresh water. 
I think the most common disease in turkeys is cholera and the greater part of that is brought on hy the way they are fed. In the first place nerer allow the turkeys to drink stagnant water, such as they get in the fall when streams are low, or around the stable, ete.

Do not over feed. During the seasons when bugs and inseets are plentifu], feed very little grain, just a little in the morning and night. Too mueh animal food will get their bowels too lose and this is the first stage of cholera. Cholera is an easy disease for me to cure as I use my own remedy and it has never failed yet.
There is not as inuch disease as there used to be and there would be still less if the farmers and breeders would use a little more judgment and caution in their feeding and breeding. Jubreeding is almost a sure sign of failure in the turkey business.

\section{GET TILEN LARGEI}

There is one thing we all want to work for and that is to get more size and that is what you will not get if you inbreed; so, let us work together and build np our turkeys until they will be true to the name-Nammoth IV bite IIollands.

\title{
RAISE MORE TURKEYS
}

\author{
A Western Breeder of Turkeys Thinks the Farmer Who Does Not Raise a Flock of Turkeys Makes a Mistake-She Finds Them Easy \\ to Raise-It is Essential to Have Good Pareot Stock
}

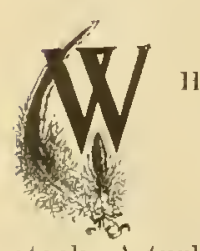

\author{
$11 \mathrm{lN}$
thi
en
tu
} LN one decides to raise turkeys the first hing to do is to invest in good, somnd parent stock. I do not believe mueh in buying turkey eggs to set, as so many persons are ot careful enough abont the breeding turkey that has been eured of roup or any otlue disease will not make a good breeder and the young wil not be as sound nor do so well as you expect them to do. I would advise beginner's to buy good stoek.

In seleeting my own birds I always piek the largest boned birds that $I$ have. If both the hen and the gobbler have large extended broasts the young will be strong and healthy.

I feed my breeding turkeys just the same as I do my breeding chickens and they lay around the barn or hen house and do not wander far away.

Ten or twelve lens may be liept with one gobbler and almost every egg will hatch if the gobbler is vigorvus. He should be a year or a little older. I prefer that the heus be cne or two years old as they are stronger and lnow better how to care for their young.

$I$ always set the first laying of eggs under good, old Plymouth Rock hens and then break up the turkey hens. In a few days they will be laying again. This second laying the turkeys are allowed to hatch and they will rear them so that they will make fine birds hy Thanksgiving if they have any show at all.

As we live on a farm we give the turkeys free range. As the grain ripens, the alfalfa is green and the grass huppers are plentiful, sn with plenty of fresh water at hand, the turkeys do not need my care-except at nightfall-aiter they are old enough to allow them to roam.

\section{FEED AND CARE OF YULNG TLRKEYS}

'The young poults are kept in a large coop until they are two weeks old, at which time they are strong ani? ready 1.0 follow the rikl turkey. She knows when they have goamed far enough and sle will hover them when they need it.

Great care slrould be taken not to feed the young poults too much at one time. This is the rock, if I may be permitted to use this figure of speech, on which the frail barks of thousands of ponlts have struck and gone down, together with the plans and lopes of their zealous but misguided nwners. The natural habit of turkeys is to hunt for their food and they do it slowly and rleliberately all the long day. Thus the process of eating and digesting are sinultaneous; but when they are fed with a lavish hand they gorge themselves and in a few weeks fall vietins of their own greed.

I prefer the White Holland because they do not roam nearly so far as the Bronze. If you mate them well they will grow very large. 'The first feed the poults liave is hard-boiled eggs. They are boiled a long time so that they will be erumbly when mashed with a fork. Eggs so coolied are easily digested, and they should be sprinkled with black pepper. This is all I feed for two days, giv ing them fresly water to drink. Then they are fed Dutch cheese, peppered well, and prepared chick feed with green unions chopped fine.

There are no floors in my turkey coops, but the coops are removed cvery day to new ground. A large shingle is kept on whieh the little turks are fecl. It must be kept elean, for when it gets dirty they will not eat their food from it. They are fed four times a day while they we cooped, but only twice while they roam, that is in the morning and al night. Some feed small turks too often. Their digestive apparatus seems to be very delicate at first. Overfecding causes the death of a very great muy lithle turks. If one fed them every time they come ruming they would be eating all the time and they (ammot stame it.

\section{BENEFIT TO GROWING CROH'S}

Turkeys by nature are prone to wander over the fields for a great share of their living, thereby galning a healthy, robust constitution and at the same time ridding the fields and meadows of grass and weed seeds, grasshoppers aud other insects that are harmful to growing erops. This certainly is converting evil into good. They will do this in the fall of the year when the eorn is ripe and never disturb the ears of corn. Nine do, but I always feed my turkeys at home some.

Put the turkey coops near the alfalfa field if you ean and all the day they will roam through the alfalfa lumting bug's. It is interesting to watch them and hear them chatter away while at work.

The turkess that are not fit for breeders are drynicked with the head and feet off and sent to market. Out here 1 received twenty eents a pound and furnished the hotels with then. I sell as higly as one hundred and fifty pounds to a lotel at a time, so it is easy to get rid of all the smpolus. I think that the farmer who does not Iaice a flock of tur.ikeys is making a great mistake. 


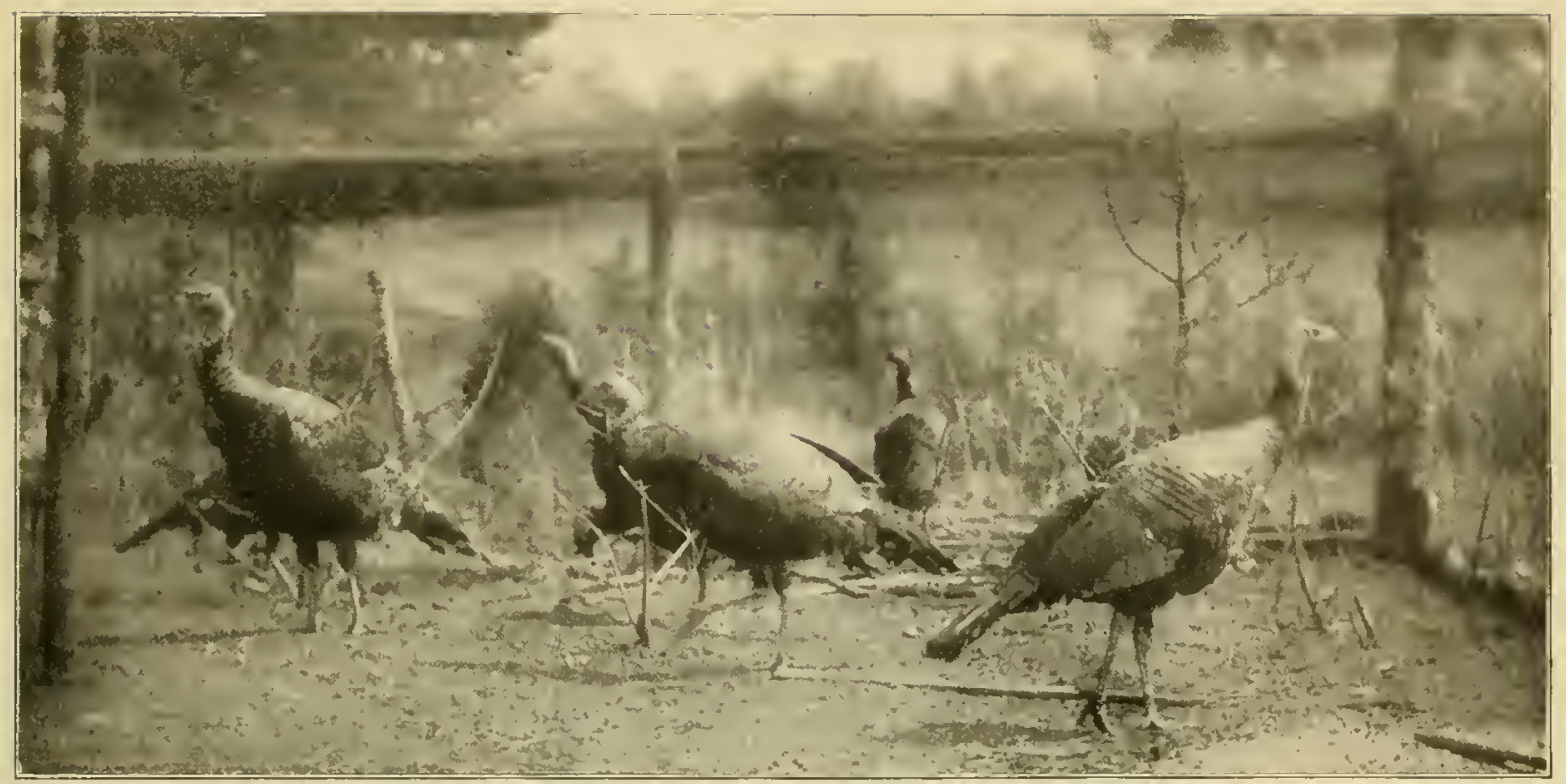

Seven llardy and Vigorous wild Cocherels

\section{WILD TURKEYS}

The Hardy Nature of the Turkey has Suffered Irom In-Breeding and Too Inlimate Association with Domestic Fowls-Relief Found in Return to More Normal Conditions and the Infusion of Wild Blood

\section{RORERT LEE BLANTON}

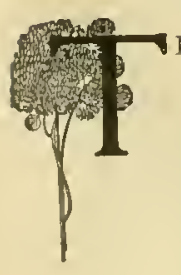

$11 \mathrm{~F}$ turkey raising industry has recently suffered greatly from a multiplicity of cliseases that have infested these fuwls. The losses have bcen chiefly among the ponlts. For many of these diseases, no sure remedy has heen diseovered, and many persons who hitherto found this brameh of poultry eulture quite luerative, have given up the lusiness in despair.

It is almost certain that the originally hardy nature of the turkey in the wild state has suffered most from too much inbreeding and from too intimate association with barnyard fowls. 'Those familiar with the nature and liabits of wild turkeys are well aware that these birds are the hardiest and most virile of the gallinaceous speeies. They hare for several centuries struggled with man, heast, birds of prey and the elements so that their existence has depended upon the surviral of the fittest. Thus it is that only the fittest survive.

For years I have made a careful study of wild turkeys in their mative haunts. I know where they feed, what they eat, how and where they seek their nesting places, how they rear their young and how they eseape the huntes:

I have never seen one that seemed to have died from any lisease, and it is a mistake to believe that the young turkey camnot be raised upon damp ground. I have observed that they prefer the ereek and river bottoms, and I hare repentedly seen Hoeks of yomg wild turkus retreat from the rising waters of cleeks and rivers after. prolonged rains, and noticed that ther returned to the swamps as the water receded. The roung feed almost entirely upon inseets, and swamps with nearlyy fields and swoodlands abound in this lind of food.

Not only is the wild turliey the lardiest of our ma- tive gallinaceous birds, but it is also the largest and most handsome. No one who has ever seen a magnificent gobbler strutting in the sunlight, his rich bronze feathers reflecting colors of gold, green, red, purple and blue, will forget the sight. I have sten males that appeared to be eight or ten years old, judging fiom the length of their beards and their spurs. The older they are the richer their plumage beermes. I reeall shooting one some years ago that had a beard fifteen inches long anc spurs an inch and a quarter in length and almost as sharp as those of a game cock. I suspect that I have killed as many of these splendic game birds as anyone of my age.

Some years ago I coneluded to try an experiment in domestieating them. I succeeded in capturing five young ones only a few days old. These I raised with a domestic turkey that had just hatehed her own brood. Fortunately, one of these I eaptured was a male. When they were three months old and hegan to show indications of longing for their kindred in the woods, I enticed them into an enclosure that I had constructed for their future home. This enclosure was made with six-foot poultry wire and was covered with the same material. I made the pen thirty feet wide and a hundred and fifty feet long, constructing a roost at one end of the enclosure twenty feet high. The following year the hens laid and I set the egg under domestic turkeys and raised quite a flock snceessfully. I then began to enlarge'my enclosure, and to construet other's similar to the original one. This I have done from time to time until now I have three aeres thus enclosed. The pens are well set in grass and clover and are furnished with abundant shade by vines and shrubbery. I have now sheds to protect them in bad weather. The first birds capturerl had no protection from the weather. 
I hare added to mr stock from year to year by capturing other birds and finding eggs until $I$ hare all the rarieties except that found in Central America. Onr Virginia rarietr is the largest of all the rarieties. I have one gobbler that weighs thirtș-eight pounds, and my friend, Mr. Y. F. Wood, the taxidermist for the Smithsonian Institute, agrees with me in believing that this bird is likely the finest specimen in existence. Only one other of which I hare read approximates this one in size or markings, and that one is described by A udubon. That one weighed thirty-six pounds.

By judicious mating, I hare increased the size of my birds each year. And as I hare $\mathrm{ms}$ pens divided in sections, I can mate the birds as I please.

I keep the feed bins well supplied at all times with corn, oats, kaffir corn, grit and charcoal. They nerer lack food. drink or shelter. $\mathrm{BF}$ kind treatment I can now turn out on free range all $\mathrm{my}$ birds except those most recently captured.

I do not allow $\mathrm{my}$ wild hens to hatch the roung, as I hare learned that enrironment is worth more than heredity in dealing with both the roung of man and other animals. I always select the gentlest domestic turkeys to do the incubating, and $I$ raise the roung on free range. I feed them just the same as I would the domestic turkeys, and I hare learned that it is best to feed young turkess very sparingly; in fact they seem to get along very well making their own living. The bug or grasshopper that can escape the keeu eye of a young wild turker is indeed fortunate.

$\mathrm{By}$ careful experiments I have found that the wild turkeys are not subject to many of the diseases that in fest their domestic cousins. But I am careful to aroid

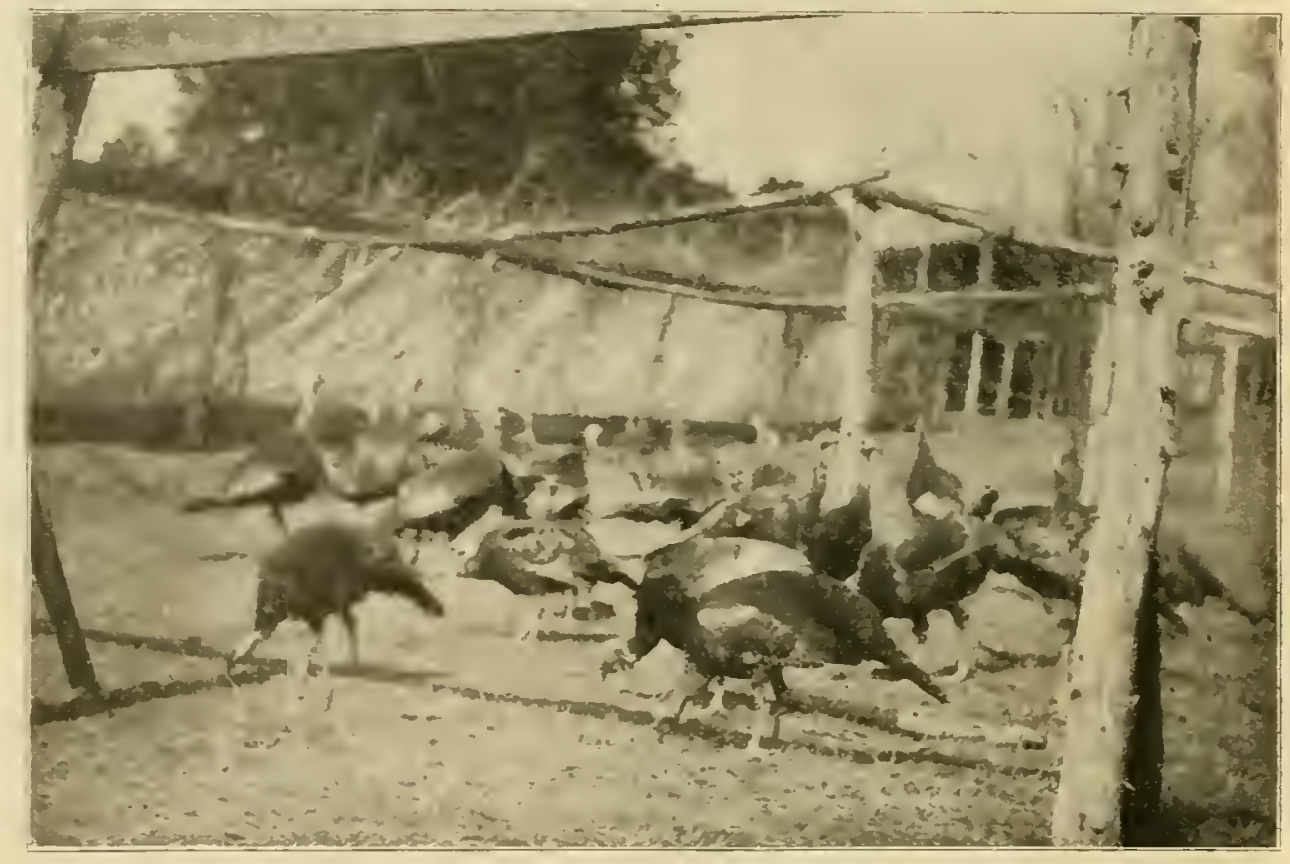

Section of Enclosure Showing Portion of Flock

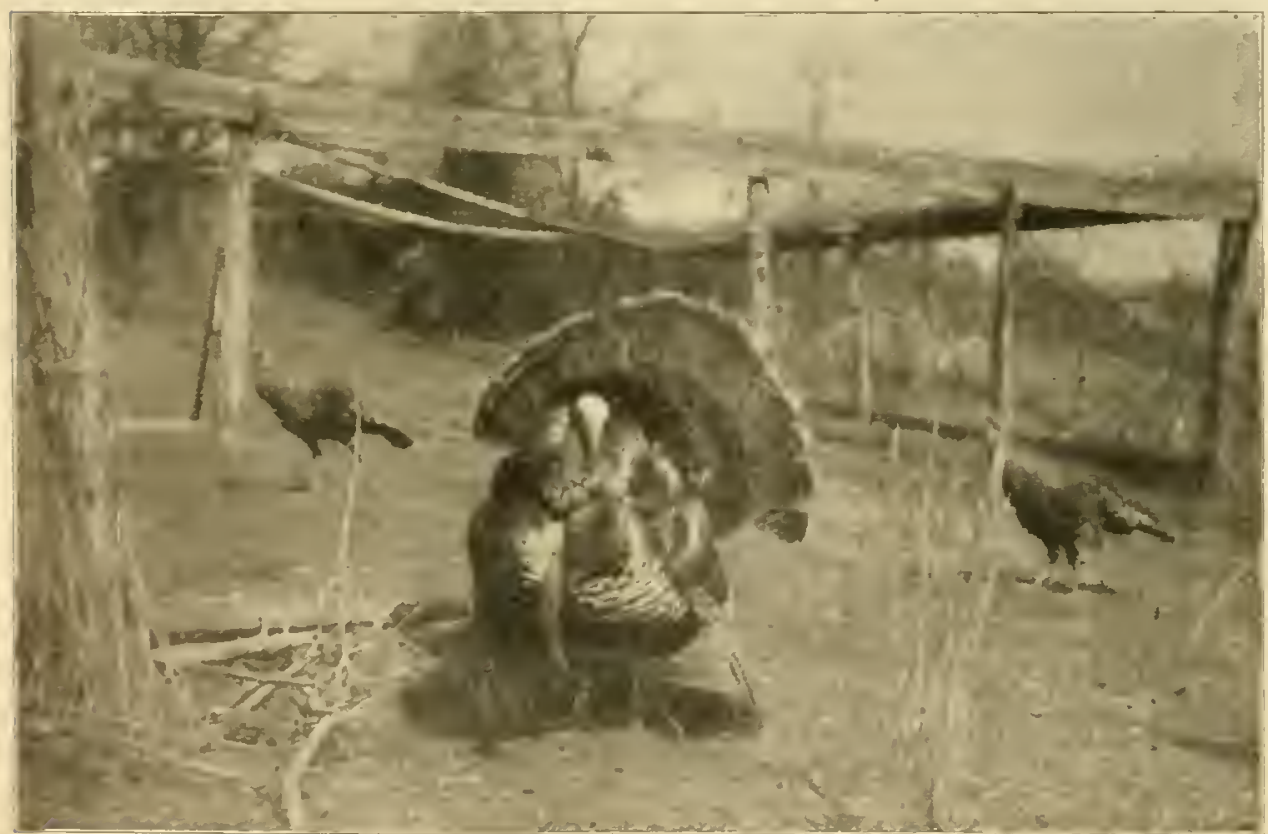

A Wild Tom inbreeding. Every year since I began breeding them, new blood has been added.

On the fifth of April I set twenty-one eggs, and twenty-eight days after this, twenty healthy poults were hatched. They are now giring every indication of surriving the long rainy season we usually hare in May. I have two hundred eggs that are due to hatch the last of this montl (May).

The demands for my stock and eggs are so great that I can not fill all the orders. I am shipping birds to foreign countries. On the eleventh of this month I shall send a pair to Italy.

The wild turkey can be crossed with any domestic turkey and the infusion of wild blood is sure to add vigor to the stock. I would, howerer, advise all those who intend purchasing wild birds or eggs to be sure that they get genuine wild and not some that hare either lost their virility by long inbreeding or by continued erossing with the same domestic turkeys.

It is $\mathrm{my}$ firn belief that the hope of the turkey industry depends upon the breeding of wild turkeys or upon crossing them witl the domestic turkey. 


\title{
THE GREAT MARKET TURKEY
}

\author{
The Chaims of the Narraganselts to this Distinction-Inbreeding-Care of Poults-Nine-Year-old Breeders-How to Begin
}

\section{S. T. JONES}

BFEED all varieties of turkeys, the 13ronze, Narragansett, Buff, Slate, White and Black. The Whites are the easiest to breed to standard requirements an account of their color and the Narragansetts are a close second, because they breed so true to color. I find the Bronze are the hardest to breed up to the standard, as it is rery difficult to get a good color throughout and when the birds are under a year old they are not matured. They are tall. leggy, and look light in the breast. If you breed what the public demands, and you must do that, you have to breed the leggy kind, because four out of fire letters inquiring for young Bronze turkeys demand size. That is the cry-size-size-size. "We want them good in wing and tail color and great, big heavy weight fellows." If you breed the plump, early maturing kind you cannot make forty or fortyfire toms out of them. You must breed the big, tall, leggy kind, and when the toms are two and three three years of age you wil find that they will weigh forty, forty-fire and even forty-eight pounds, and then, truly, you have the most magnificent bird in America. But the Narragansett, Buff, White and Slate varieties are the best market turkeys, for they mature early. The Narragansett heads the list and is usually ready for market at five or six months of age. The Buffs and Whites are next in order. The standard weights for Narragansett males (thirty, twentyfive and twenty pounds) are too high.

The cocks and cockerels should weigh the same as the Buff and Slate tur-

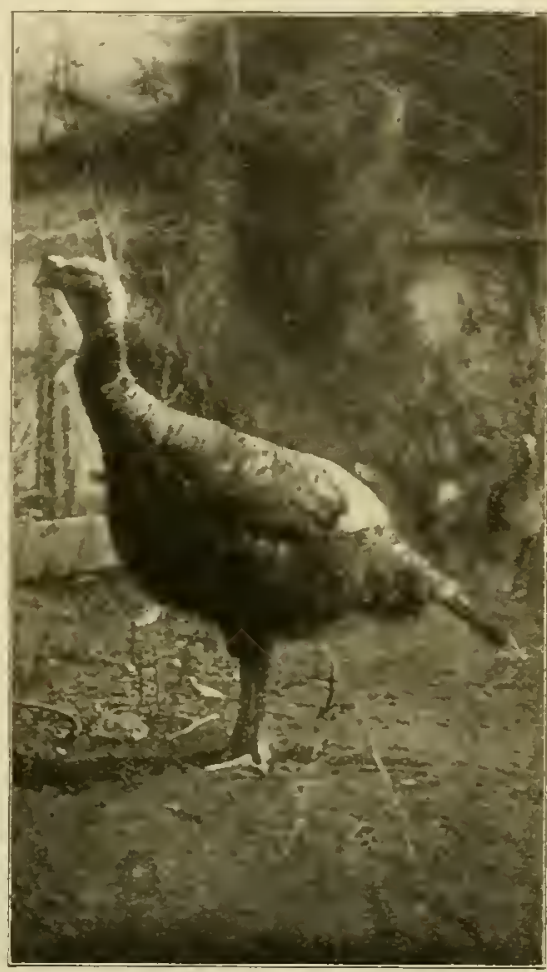

A Young Mexican entire farm. 'Turkeys that are hatched in the spríng will lay the following spring and different turkeys will Iay a varying number of eggs. The Narragansetts lay more than any other variety and the Buffs are next. I harc lıad turkers that laid the entire season and did not offer to sit, while others will lay from ten to fifteen eggs and hecome broody. We keep from five to eight hens with one male, as we think that we get better results as a rule than we do if we have a greater number of females, though we have had from twelre to fourteen hens with one male and the eggs were all fertile. Probably 90 per cent of all turkey eggs are fertile unless the turkers are orerfed, and consequently are too fat. Let them get their own focd by roaming orer the pasture and stubble lands.

\section{CARE OF POLLTS}

It takes from twenty-seven to twenty-nine days to hatch turkey eggs. We have not tried hatching them under hens. For the first twenty-four to thirty-six hours after they are hatched we feed very small grit or gravel, and then we feed clabber cheese dry and some corn meal. a little millet seed or small cracked wheat. We keep the hen and poults in a small pen for eight or ten days and then put them ont on pasture land. They need rery little food from this on, and should not be fed more than once or twice a day for the best results. Turkeys get nearly all their food from the fields in summer and fall.

Pasture and stubble land are the best places for them to keys, riz.: Twenty-seren and eighteen pounds, for they are short legged, plump and mature early.

An excellent illustration of the Narragansett turkey appears on page nine of this book.

\section{INBREEDING-RANGE}

I introduce new blood into my flock every two or three years. I do not think it necessary to do so oftener, as I keep from two to six flocks of each rariety, but I never inbreed turkeys, as I find it will not do. I breed all the rarieties for exhibition, and when getting new blood I aim to improre in all sections, both in shape and color. The breast, body and back are the most important sections in shape and the rings and tail the most important in color. We do not raise turkeys in confuement. They must have a large range if we are to attain best results. I never house my turkeys, as I think they do better when raised in the open. The nearer we come to raising them in the natural way the better it is for them. I do not try to fence against them. but gire them unlimited range. We keep only one ra. riety on a farm and give that variety the run of the run. In the fall begin feeding corn, or, if you are feeding cattle or hogs, the turkeys will get all the food they need, for they always manage to find the feed lots. The main secret in successfully feeding turkeys is to give them their food regularly, but be careful not to sive too much. More turkeys are fed to death when they are young than die from any other cause. Nine out of ten breeders feed their poults until they kill them. I have had persons tell me what they feed young turkeys ind then say: "Afy turkess do not seem to grow well, and I know I feed them well." I do not see how ther manage to raise any at all. I am sure I could not if I fed as the do. Remember to feed lightly, always using the best of food and never feeding any damaged grain at all. A bushel of corn will feed a turkey from sixty to serenty days if it has the range of the farm. The dealers want turkeys weighing from ten to sixteen pounds and not orer tirenty pounds.

\section{A PREMIUN ON NARRAGANSETTS}

There is a difference in the quality of turkess and I claim that the Narranasett is king. There are turkeys 
that can beat them on weiglit, but when it comes to quality, no other breed can be compared to them. I sell most of my ruarket turkeys here at home, and sell them alive if 1 can. One firm liere buys most of my turlieys and they always engage all the Narragansetts 1 have to spare and asli me why I do not breed them exclusively. I get a preminm of 2 to $21 / 2$ cents per pound on Narragansetts. The Buffs are my next choice.

Iny turkers that are off in eolor or the least bit out of sliape and all of the late hatched and under weight turkeys are elassed with our market turkeys, Befure marlieing I feed all that they will eat in order to have them fat, and market all that are leady at 'Thanksgiving time and the balance of them at Christmas. As a rule, yearlings make the hest breeders, but I lave kept some ineeders mutil they were eight or nine years old.

A turkey is most delieate from the time it is hatehed until it is six or seren months olk. If I were to name the two principal eanses of the mortality among turkeys I should say overfeeding and lice. They should never be allowed to live on low, swampy ground. It is not fit for turkeys or any other kind of poultry. We raise from three hundred to a thousand.

If I were to embarle in the business of raising turkys and had the benefit of nly present experience, I should buy from some reliable breeder a tom and four to six hens and should insist upon getting good ones. I should not begin by buying eggs. I should also insist that the tom and heus be not related, and I should never in breed.
Writing for the Reliable Poultry Journal on the subject of turkeys, a prominent eastern poultryman said the following about our favorites:

"We have always had a partieular liking for" the Narragansett turkey. It is nearly as large as the Bronze and equally as good for the table. Its plumage is very striking, giving one the effect of a black and white barred plumage; and as a resident of Rhorle Island, the writer feels that the state which has the beautiful Narragansett Bay ought also to breed quite largely the beautiful Narragansett turliey. But it loes not. Patriotic as Rilode Island is in other respects it does not let its patriotism extend to any great extent to its seleetion of turkeys.

"The Narragansett tools its name from the Indians who once dwelt here, and was at one time more extensively bred in lihocie Island than now. We are reactionay to the extent of wishing for a return of the good old times in turliey laising when the Narragansett turliey was the favolite breed, altluough, gentle reader, we will confess that any litode Island turkey, onee bred and fattened here, if stuffed with Providence River oysters nnd nicely roasted, lus a very satisfactory effect upon our palate. It may not equal a genuine Rhode Island clam-bake, but it comes when elaw-bakes eannot he had, and it is so good tlat one can say, after eating of such a lish:

"Set the world do its worst, l have dined today." "

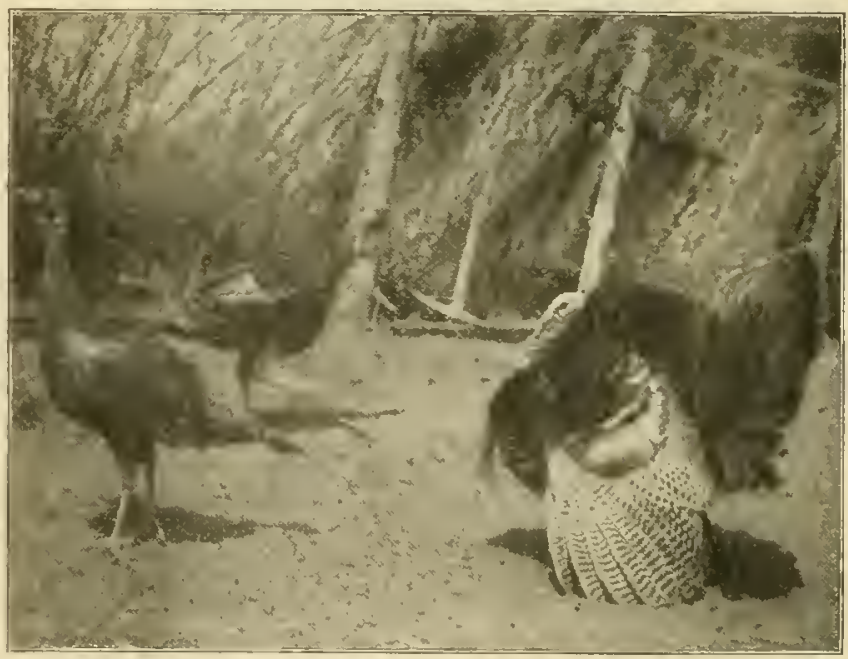

A Wild Tom

This bird is believed to be the largest wild turkey in existence. weighs thirty-eight pounds and was two years oid at the time the photograph was taken, Note the perfect wing. See page 80 . 


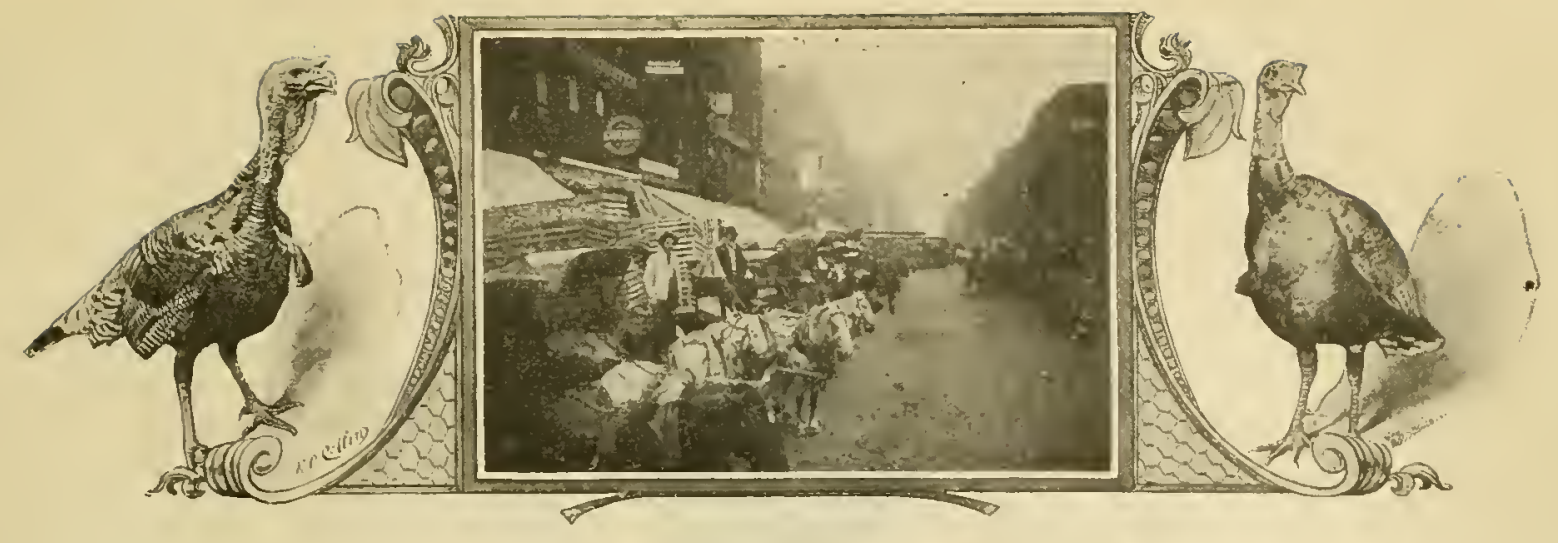

\title{
MONEY IN TURKEYS FOR THE HOLIDAYS
}

\author{
Great Magnitude of the Business-How the Commission Men Obtain the Birds-The Care of Turkeys on the Farm-Methods of \\ Fattening-Steady Rise of Prices in Recent Years-The Melhods of Killing and Dressing
}

\section{FRED HAXTON}

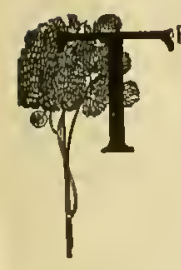

E turliey is king. In November the "Great American bird" lolds undisputed sway in every butcher shop from Maine to Oregon and from Canada to Mexico. Not until a week after New Year's day does his rule expire.

'There is money in raising turkeys for the holiday, trade-lots of it. Going into South Water street, Chicago, on an aflernow as early as Yovember 1 and seeing drayloal after drayload of turkeys unloaden, with seemingly no cul in sight, the spectator departs with the impression that enough tinkeys are grown in the middle west alone to supply every man, waman and ihild with one for every meal and leave a few thousand for the Fiji Islanders and other benighted heathen.

\section{MIISITTHE OF" TIL IBLSINESS}

Juring the boliclay rush or preceling it $678,000 \mathrm{tur}-$ keys, ralued at $\$ 1,356,000$, are received in Chicago, according to estimates made by a number of prominent pouttry dealers. Tlue bulk of the business is so grent that exact figures are impossible, but an idea of its magnitude may be secured when it is stated, in the words of the largest buyer, "The cars required to contain the turkeys shipped to Chicago for Thanksgiving, Christmas and New Year's dealers, ete., would make a train seven miles long."

"It will surprise sume people to learn that on bundreds of farms in Iowa, Illinois and Missouri turkeys constitute almost the principal "erop," said a large dealer. "Trips of buyers through the turkey country show that it is common for one farmer to have 300 turlieys, and flocks of 700 or $\$ 00$ are not extraordinary. As ligh as $\$ 1,000$ has been paid for a single consignment of turkeys. Nearly 25,000 have been disposed of in Chicago .in a single day."

While warn weather lasts a large part of the shipments of turlieys received in Chicago are lire birds, but when the temperature becomes low enough to insure the safe keeping of the meat, the fowls come dressed and packed in barrels. The production in the middle west is about equal in al] the states near Chicago, but Missouri is the greatest producer in the world. During resent years Texas has made remarkable advances in turkey raising, the climate during the spring season being especially farorable. Marketmen are depending on this source of supply for a large inerease during the next few years.

Chicago is a strategic point in the turkey trade, for a large proportion of the birds sold in New York and otler eastern cities as "Vermont" and "Rhode Island" fowls are shipped from the west. Desperate campetition rules among the fourteen firns which ship stock east, as each is trying to "corner" the market. One of them almost succeeded a few years ago by a norel plan. To each dealer or farmer. who shipped to him he allowed a guess on the highest price which turkeys would bring at any time before New Year's and to the winner he awarded a $\$ \%$ wagon. Many of the comnission men offered prizes for the same sort of contest later, one of them putting up as stakes checks for $\$ 100, \$ 75$ and $\$ 25$.

\section{HOW TTIKKYS REACH THL MARKET}

"How do we get the turkeys?" repeated the proprietor of a store in front of which were stacked coops containing nearly 500 birds. "I'll tell you: We have a couple hundred regular shippers, some dealers and some farmers, in country towns. Each spring we write them letters pointing ont to them that the raising of turkeys is the most profitable business a furmer can engage in, and urging them to be sure to hatch more turkeys than ever before. Ilien late in the summer we write to the men, asking them how many turkeys they can provide for the loliday trade, and to be sure we will hare our fair share of the birds we send our buyers out on trips, some of then s00 niles long.

"The buyers visit certain towns where the turkey production is enormous, contract wherever possible for the purchase of all the fowls, and then drive to the farms and see the farmers themselves-or ratuer the farmers' wives, for we have found that the women are the ones who really hare the "say" as to when and where the stock will be sold. My head buyer the other day handed a Missouri woman $\$ 563$ for her flock, and she said she was saving the money to buy another farm to raise more grain to fatten more turkeys with, so as to 
buy another falm, ete. She finds there is more money and less trouble in turkeys than in hogs."

\section{METIODS OF REARING}

Letters received by commission men from some of their largest growers of turleys tell the story of their success. Some of the hints gleaned from them are:

Do not try to raise the fowls in small quarters. Wherever possible turkeys should have free range. An excellent place for the fowls is an orchard, with a high fence. They will keep the trees almost clear of insect pests and secure a good deal of their food in this way. An orchard is an excellent place to keep them when the grain is ripcning and they would do damage. Be sure thebreeding stock is large and healthy. To avoid close breeding exchange toms with a grower who has different stock, or buy fine males. Have one tom for every dozen fowls or less.

Turkeys should be allowed free range the year around, if possible, except when the grain is ripening, or even then if they can be kept out of the fields. Turkeys like to bide their nests, and if they do this there is a strong chance that a sudden rain will catch the poults and kill them. For this reason the hens should be set where they can be kept shut in after the poults are hatched. Many breeders let the fowl select the place for lier own nest and then, to protect the turkey from rains and the young birds from storms, place a $V$-shaped roof over the nest. In early spring the eggs should be removed daily while the bird is laying, to prevent chilling, but a nest egg should be left.

After the eggs are hatched care should be taken to prevent the chicks from being wet or going out in the wet grass, until they have grown considerably. Many make runways about eight feet long and four feet wide, with the top and sides covered with wire netting. With these a coop four feet long and two feet wide is used, having a wooden bottom to prevent the poults from being flooded out in case of sudden storms. As the runway keeps the mother from wandering it also protects the young chicks. This device is in general use in the "turkey country."

Most of the growers permit the turlieys to roost the year around, principally because the birds never were taught to roost in sheds or houses, but the most successful erect lean-tos against the sicles of barns and place roosts under them. These are shelters without fronts, attached to the buildings at an angle a little greater than the middle line of the letter $\mathrm{Z}$.

When turkeys are allowed free range they do not require a great deal of grain or other food in summer, as they eat thousands of grasshoppers and other insects. The process of finishing them for marlset generally is begun along in August, when some grain is fed. The grain feed gradually is increased, until in September the birds are given all the corn they will clean up twice a day.

"The finest turkeys we get," said a dealer who makes a specialty of fancy birds, "come from farms in Missour. where they are penned up about the first of October and just stuffed with corn, skin milk and any other feed they will relish until about a week before Thanksgiving when they are dressed. The yard is about a quarter of an acre in size and from 300 to 500 turkeys are fattened in it annually. The owner tells me that the corn he puts into the turkeys bings him about three times what it would fetch in the market; this is in added weight alone, not connting the extra price per pound paid him beciuse of the fine condition of his stock."

Comparatively little of the turkey crop is killed and dressed by the farmers. Most of them actually drive their stock to market, taking a flock of a conple hundred or morc turkeys and conducting them to the wholesale purchaser in the nearest village or to a point where crates are waiting to take them to the nearest large city. When the grower is ready to market his stock he generally notifies his dealer in Chicago or elsewhere, and the latter immediately sends by express enough coops to contain the shipment. These are taken any distance by the express companies for only 10 cents apieee, which is much cheaper than the making of new coops for each shipment would be.

\section{IIOW I'REPARED FOR MARKE'T}

In late November and December most of the turkeys are dressed in the country. Each of the dealers demands that the fowls be prepared to suit hing; if they are not, le sometimes refuses to purchase them at all. Following is the "lettcr of instruction" sent to each large turkey grower by Geo. McCutcheon \& Co.:

"Keep from food twenty-four hours. Kill by bleeding in the roof of the mouth or by cutting a vein in the neck; never take off the head. Hang by feet until through bleeding, and leare the fcet on. Nerer scald a turkey. Dry-pick while the fowl is still bleeding. Do not wait until the body gets cold. Be careful not to break the skin; do not draw entrails or crop; remove all the feathers from the wings. Remove pin feathers thoroughly. Hang in a cool place until the animal heat is entirely out. This is very essential.

"Wrap head of turkeys with clean light brown paper. I'ack sluugly (to prevent moving about) in boxes or barrels lined with clean paper. Boxes holding 100 to 200 pounds are best for all fowls.

T'urkeys show up hest if the body and legs are straightened out. Mark weight plainly on cover, and secure box carefully to avoid breaking open in transit. It should be noted that dry picked turkeys or other poultry is best for shipping in warm or doubtful weather. Poul1ry frozen will not commiand as good prices as that which is not. Old and heavy tom turkeys should be marlieted beforc the holidays, as later the demand is for round, fat hen turkeys only."

Another dealer gires this advice:

"Turkey feathers should be pulled out with a twist. A straight pull will 'set' them. Dressed turkeys, when dry-picked, always sell better and command a higher price, as the appearance is brightel and more attractive. Broken ice should be placed all through the barrels-that is, a layer of turlkeys and a layer of ice broken to the size of a fist. Fill the barrels in this manner and then on top of the turkeys place a large cake of ice. If turkeys are shipped alive, strong coops should be used, as they get especially rough handling during the holiday rush, and they should be high enough to allow the turkeys to stand up. (Bc careful not to orcrerowd). 
FEA CHERS HAVE A VALUE

"Save the feathers. They are valuable. We offer the following prices per pound:

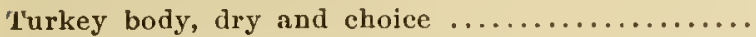

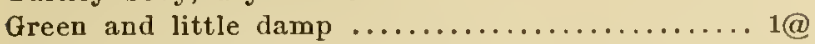

White turkey body, dry prime $\ldots \ldots \ldots \ldots \ldots \ldots \ldots . \quad 50$

Tail, choice and clear ..................... 40

Tail mixed with skirt feathers ...............20@25

Wing, from first two joints ................ 20

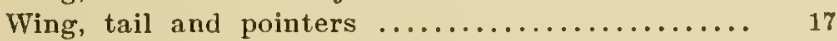

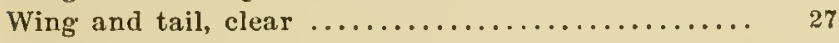

Wing and pointers $\ldots \ldots \ldots \ldots \ldots \ldots \ldots \ldots \ldots \ldots, 13$

Pointers .. ........................... 7

"Despite the fact that all dealers agree more turkeys have been raised this year than ever before, the prices are unnsually high. The ten pound Thanksgiving dinner that $\$ 1.25$ would buy a few years ago at a shilling a pound was retailed at $\$ 2.25$ to $\$ 2.75$ this year. The high prices are explained by a turkey expert as follows:

"For some time before the Thanksgiving demand came the retail butchers catering to select trade were placing their orders for turkeys at 23 cents a pound, dressed. This means the wholesale price, and as the retailers figure out a profit for themselves of 2 or 3 cents a pound, the consumer had to pay 23 cents a pound for turkeys delivered on these orders. Only the finest birds were pre-empted at this high figure, but the average range of prices was around 21 or 22 cents.

"There is an obrious reason for the "kiting" of the price of turkey meat. The current explanation in South Water street is that the big stockyards packers and other large purchasers go into the country early and succeed to a large extent in 'cornering' the turkey market by the expedient of buying up the entire visible supply through agents in the choicest turkey raising districts. This is declared to have happened in many states, especially Kentucky, Missouri and southern Illinois. It is common gossip among the South Water street commission merchants that the leading packer in the socallèd Chicago 'big-four' combination sent his agents into Kentucky a few years ago and purchased virtually all the 'turkey futures'--the Thanksgiving erop-in the great turkey-producing district kuown as "the territory north and south of the Ohio river."

The great Thanksgiving rush begins the Monday before Thanksgiving, but preparations for it are made for weeks, the birds being killed as fast as received, the surplus after the daily sales going into coolers. One hundred and sixty meu were engaged last year in dressing turkeys alone, several large establishments being in the business of killing and dressing poultry for other dealers. These are known as poultry slaughter houses. More than 500 turkeys a day are dressed during the rush season for each of the large commission houses.

The grower of turkeys is sharing in the prosperity brought by high prices, but investigation shows the wholesale dealer and the retail butcher get a large share of the profits, together sometimes making almost 10 cents a pound, although their profit generally is around 6 cents. One of these dealers, talking of the high price of poultry, said:

\section{EXIORT TRADE INCREASING}

"The export trade has grown to immeuse proportions in the last few years, turlieys leading in the foreign demaud. The home trade has grown by leaps and bounds at the same time with the foreign business.

"All the finest American ponltry goes to Europe.
The big packers are the great exporters of American turkeys."

The immense business done in poultry hy the "beef trust"--amounting to millions of dollars a year-has a great effect on the turkey market. Swift \& Co. filled a contract for 55,000 pounds of turkey for the United States army.

The price of turkeys raries more than any other kind of poultry. In summer the birds sometimes sell as low as 13 cents a pound, live weight, and in winter they occasionally reach eighteen cents, alive. Immediately after the New Year's demand is supplied there is a slump in prices, and it is then that the speculators buy their stock of thousands of birds to be placed in cold storage and sold the next summer. The "good prices" for turkeys, as the dealers call them, begin to come around Norember 1 , when the birds hring about 16 cents a pound, live weight. The prices will keep up well this year, probably equalling those of last winter. Even last August, when turkeys generally are at about their lowest point, live birds brought 15 cents a pound.

During November and December there is a great demand for young turkeys, which dress about three to five pounds. These bring fancy prices, and the demand is not filled. Few are seen in the wholesale markets because the growers generally contract directly with butchers to take oft their hands all they can raise. Such stock has sold for 22 cents a pound, dressed. The smaller of the baby turkeys, as they are called, were used as "fryers," and those that weighed four pounds or more were roasted. The bulk of the old turkeys that come to the market weigh about 12 to 15 pounds apiece, but sereral that tipped the scales at more than thirty-five pounds were seen in the stores last fall. The extremely large turkeys, howerer, are not in great demand, as they are too heavy for family dinners and difficult to roast when bought by hotels.

\section{A FAMOUS GROWER}

The most famous grower of turkeys in the United States is Horace Vose, of Westerly, Rhode Island. Mr. Vose last year followed his annual custom of sending a Thanksgiving turkey to the president of the United States, a custom which he began in Gen. Grant's first term. He has autograph letters of thanks from all the presidents since then. Mr. Vose goes to a great deal of trouble to get the president's Thanksyiving dinner. Besides growing turkeys he deals in them, and after the chiclis have been hatched a month or two he makes a tour of the farms for miles around. If he sees a particularly fine chick be secures an option on it, and directs that it be given special care. He makes other visits later in the season and bids for every fine turkey that he sees. When Thanksgiving approaches the Rhode Islander has control of practically all the finest birds for miles around. He is the largest shipper of turkeys for the New York market. This is Mr. Vose's philosophy:

"The object of fattening a turkey is to produce firm, finely flavored, luscious flesh. Therefore it should be fattened on whole corn-not meal-as the corn gives a firmer consistency to the flesh. It should never be stuffed artificially or confined in close quarters. If sweet apples are available they may be fed, as nothing will give a nicer flavor to the flesh."

"In July and August growers near fashionable resorts sometimes sell turkey 'broilers,' weighing from $11 / 2$ to 4 pounds each, for $\$ 3.50$ to $\$ 4$ a pair," writes Helen W. Atwater, government food expert.

The last gorernment report shows there are 6,599,- 
367 turkeys in the Linited States, of which only 529,993 are in the North Atlantic states-Rhode Tsland. Naine, Vermont, etc. The bulk of the turkeys in the country are in the nortl central states, which have $3,072,456$, while the far western states have only 304.950 .

\section{MACIINE FATTENING TURKEYS}

The Lonilon Boarcl of Agriculture reports great success in fattening turkeys with a eramming machine. I

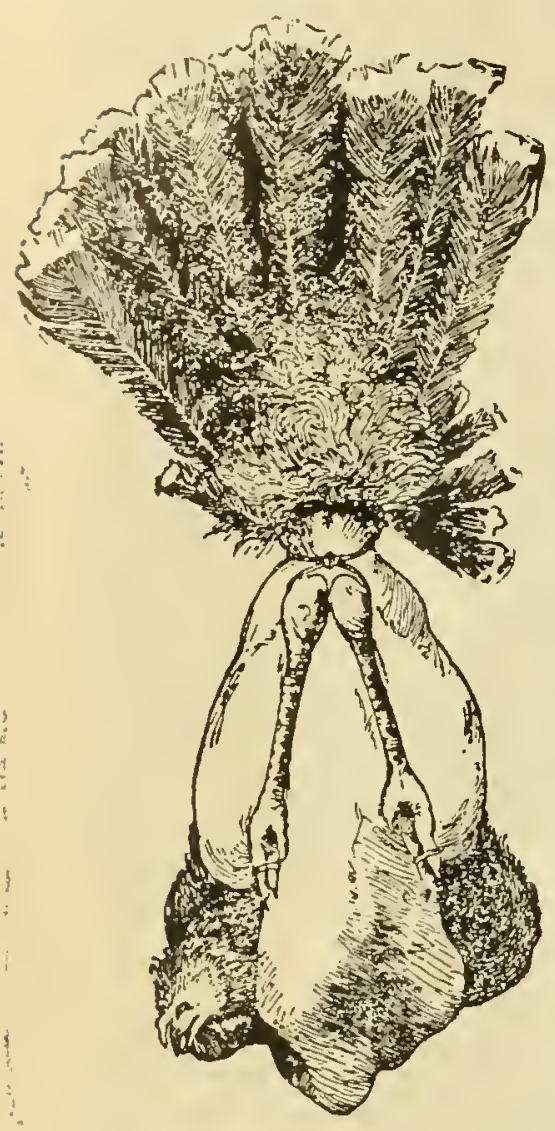

Fig. 2.-Breast riew showing method of tying legs and pushing head under wing. mash of equal parts of gromud barley, corn and oits, with a small ammont of melted fat and linseed meal was used, enough skim milk being arliled to make it the consistency of cream. At first there was difficulty in feeding the turkeys, owing to their size and strength, but the operator finally overcame this by placing the fowls on a low stand so that their heads were on a level witl the nozzle of the cramming unachine. It is stated that "after" a day or two the turkeys became aceustomed to this manner of ferding. and when meal times enme they showed much eagrriess to mount the stanrl and receire their share of the food." "The feeding period coverer three weeks: the birds were hatchesl in the spring and weighed an average of serenteen pounds apiece, and made an average gain of four pounds four

ounces. This was done at a cost of 41 cents per head.

Proof that turkeys fatten much better when kept in pens has been secured by the Vanitoba experinent station. It took two lots of birck, exactly alike and gare them the same rations for six weeks, two parts of wheat, one of oats, and one of barley. At the encl of the test it was found the turkeys in the pens had gained an average of a trifle orer four pounds each, while those alloweit their liberty adderl only a little more than $13 / 4$ pounds each to their weight. Irost of the gain was macle in the first three weeks. The penned turkers when dressed shrank 5 per cent less than the others and were more attractice in every way.

\section{TLliKEYS SENT TU ENIIAND}

Canada does an immense amount of business in exporting turkeys to England. The Canadian commissioner of agriculture gives the following description of the proper way to prepare the lirds for the liritish market, which is extremely exacting in its requirements:

"The bird is hung ul by the legs, the wings being erossed to prevent struggling. Next it is given a sharp blow on the back of the head with a stout piee of wood, which renders it insensible. The knife is then in. serted into the roof of the mouth, so as to pieree the brain, cutting it along the entire length. The bird is left hanging by the legs for a few minutes to allow the b]ood to drain out. J'luck at once, while still warm. Feathers sloould be left on the neck for about 3 inches from the head; also a few feathers on the tail and tips of wings. Do not tear the slin in plucking, and do not under any circumstances clip the bird into water. Remove the intestines from the rear. Care must be taken not to break: the gall bag. All the rest may be left inside. Twist the wings on the back of the bird (Ill.1). A string, which, however, should not eneircle the body, may be useal to keep them in place. is soon as the feathers are off, hang the lirel up loy the feet to cool. Do not lay it down or hang it by the head. The blood should drain toward the hearl and lecome coagulated there. One dealer says to lay the birls on their breasts on a setting board, pressing the rumps square, letting the heads liang down until the body is set, when the birds will always retain their plump shape. Cleanliness is necessary. The feet and legs of the birts should be clean also. The legs of the dresserl birds are often tied $u p$ as in illnstrations 2 and 3 If the lirds are to he displayed in a shop the head shunls be pushed up under the wing. The birds shumld be thoroughly cooled (not frozen), and they should lie cold through and through before being packed in cases.

"I'ack in any one case only birds of nearly the same weight, graderl to within two pounds. In no ease shouls any hird be lighter than the lightest weight or hearier than the lieaviest weight marked on the package. Pack the cocks and hens in separ. ate cases. Mark the cases at botl cncls plainly. Wrap every bird neatly in paper. The hearl of each bird should he wrapped with a quantity of thick paper, to absorb any b]orrl. Spread a small quantity of wood pulp or dry. clean straw in the bottom of the ease. Put paper on the bottom and top of the birds to keep them clean. I small quantity of wood pujp or dry, clean straw may be put on top, directly under the corer. Paek the birds with lacks lown. with heads at one sirle. Put from twelve to twentyfour birls in a case. Every case should. he packerl quite full and close to prevent damage rluring transit. Do not export any old. tongh biris. Every hird should show a gurd, headunderwing. plump, whife. broat breast."

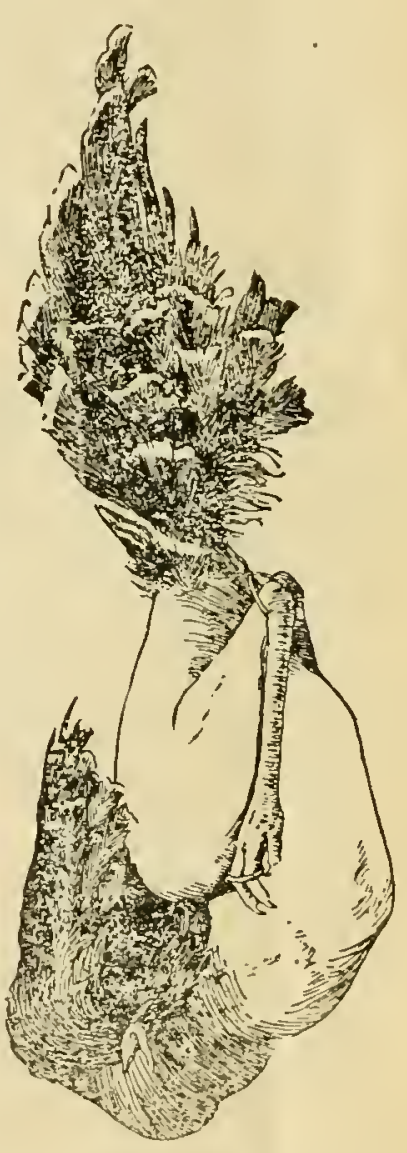

Fig. 3.- Side view showing method of tying legs and pushing

PRUE'TTABL

There is mole money in raising turkeys now tian there ever was before and there will be more next year, for the trent of prices is irresistibly upward. market experts decline. 'The figures for sereral years, furnished the lielialule Poultry Jonrnal by Howarel. Bartels of Co.. official statisticiaus for the Clicago pouttry dealers. point out reanly the great adrance in the wholesale mar- 
ket prices of turkeys in the last ten years. In the table below the prices from April to October, inclusive, are for live birds, as hardly any dressed turkeys are shipped in summer owing to the danger of spoiling. Where there is a wide variation in prices during the month the bulk of the birds were sold nearer the higher figure than the lower. Prices quoted for Jamuary, February, March, November and December are for dressed turkeys:

The quotations in the accompanying table are for the common run of stock, fancy turkeys being disposed of at special prices. The following table will show the gradual rise in prices for a ten year period. The figures for 1907-8 were unobtainable: nearly all of the $4,000,000$ pounds went to the New England markets and to the smaller eastern cities.

As a rule the birds grown in Kentucky are not of large average size, W. T. Seibels of the Packer says, and for this reason they are most desirable for buyers of large lots for holiday distribution by commercial concerns and large factories, to their employees. The average size of the hen turkeys is about $S$ pounds, and toms run from 10 to 12 pounds. Ten thousand pounds are put in a refrigerator car, and whole trainloads are shipped at once.

The lientucky association each year meets to fix the price which it will demand from the wholesale buyers,

\begin{tabular}{|c|c|c|c|c|c|c|c|c|c|c|c|c|}
\hline Munth & 1906 & 1905 & 1904 & 1903 & 1902 & 1901 & 1900 & 1899 & 1898 & & 1897 & 1896 \\
\hline anu & 17 to 18 & 17 to 19 & 16 to $17 \frac{1}{2}$ & 17 to 18 & $8 \frac{1}{2}$ to 12 & $7 \frac{1}{2}$ to 9 & 9 to 10 & 8 to 11 & 10 to $11 \frac{1}{2}$ & & to $12 \frac{1}{2}$ & 8 to 12 \\
\hline sar & 18 to 19 & 19 to 20 & 16 to $17 \frac{1}{2}$ & 18 & $9 \frac{1}{2}$ to $14 \frac{1}{2}$ & $7 \frac{1}{2}$ to 9 t & $8 \frac{1}{2}$ to 10 & $S$ to 11 & 9 to 12 & 8 & to $12 \frac{1}{2}$ & $13 \frac{1}{2}$ \\
\hline Iarch... & 16 to 17 & 19 & 16 to 17 & I5 to IS & 10 to 15 & 7 to 12 & 8 to 12 & 8 to 13 & $9 \frac{1}{2}$ to $12 \frac{1}{2}$ & 8 & to 13 & 13 \\
\hline pril.... & $12 \frac{1}{2}$ & 14 to 15 & 11 to 12 & 12 to 13 & 9 to $12 \frac{1}{2}$ & $6 \frac{1}{2}$ to 8 & $7 \frac{1}{2}$ to 10 & 8 to 10 & 8 to 12 & & 9 & 8 to 12 \\
\hline May.... & 11 to $12 \frac{1}{2}$ & 14 to $] 5$ & 11 to 12 & 10 to 12 & $9 \frac{1}{2}$ to $12 d$ & 6 to $S_{2}$ & 6 to 9 & 7 to 10 & 6 to 9 & 6 & to 9 & $7 t$ \\
\hline ... & 10 to 12 t & $13 \frac{1}{2}$ to 15 & 10 & $10 t$ & 10 to 12 & $5 \frac{1}{2}$ to $7 \frac{1}{2}$ & 5 to 7 & 6 to 9 & 5 to 8 & 5 & to 7 & 6 to 9 \\
\hline$\sqrt{2}$ & 11 to $12 \frac{1}{2}$ & 14 to 15 & 10 & 10 to 11 & $11 \frac{1}{2}$ to 12 & 6 to $7 \frac{1}{2}$ & $5 \frac{1}{2}$ to 7 & 7 to $8 \frac{1}{2}$ & 6 to 8 & 6 & to 10 & 7 to 10 \\
\hline$A$ & 12 to 18 & 15 & 12 & 11 & 12 to $12 \frac{1}{2}$ & 6 to 8 & 6 to $7 \frac{1}{2}$ & $7 \frac{1}{2}$ to 10 & 6 to 10 & 7 & to & 8 to 11 \\
\hline 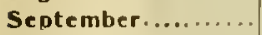 & 13 to 16 & 15 to 16 & 12 to 14 & 011 & 13 & 7 to 9 & 7 to $s$ & 8 to & 7 to 11 & & $\frac{1}{t c}$ & 3 to 11 \\
\hline$\cdots$ & 13 to 16 & 13 to 17 & 12 & 11 to 14 & 11 to 13 & 7 to $8 \frac{1}{2}$ & 6 to 9 & St to 10 & 7 to 11 & 8 & to 10 & $7 \frac{1}{2}$ to 9 \\
\hline ........ & $16 \frac{1}{2}$ to 21 & 16 to 18 & 15 to 18 & ] 5 to 18 & 10 to 16 & 7 to 10 & 6 to $10 \frac{1}{2}$ & 9 to 11 & 8 to $11 d$ & 8 & to $10 \frac{1}{2}$ & 9 to 11 \\
\hline December. & & 16 to $17 \frac{1}{2}$ & 14 to 17 & 10 to $17 \frac{1}{2}$ & 13 to 18 & 9 to $11 \frac{1}{2}$ & 8 to $9 \frac{1}{2}$ & 9 to $10 t$ & 8 to 11 & 8 & to 18 & $10 \frac{1}{2}$ to 11 \\
\hline
\end{tabular}

Think of live turkeys selling in the Chicago market at $5 \frac{1}{2}$ cents a pound, after express had been paid on them for hundreds of miles, and figure out what would be left to the grower! This was done in June, 1901. Think of dressed turkeys bringing only $i$ cents a pound, which occurred in November, 1900, and figure how much less would be left to the shipper! In fact, 1901 was a "black year" for turkey men, the highest price on dressed stock being only $11 \frac{1}{2}$ cents, and the average for the year not more than a dime a pound. 'The prices given in the table are those paid to shippers, and not those at which the wholesalers sold the stock to dressers and meat markets.

The change from 6-cents-a-pound dressed turkeys was especially marked two years ago, when on November 13-before the Thanksgiving demand was hardly more than started, dressed turkey's were bringing the country shippers 16 to 18 cents a pound when even in fair condition, while choice stock commanded its own price. A 20cent marlet was expected by many, and this means that the butchers would have to pay 23 cents upward for their turkeys and the city consumers fiom 26 to 29 cents a pound.

"Baby" turkeys were in especial demand that fall, and not one-tenth of the call for them could be met. 'These weighed around 5 pounds, some even reaching nine pounds, and found a ready market at 20 cents up, at wholesale.

\section{KENTTCKY TLRKEY ASSOCLATION}

One thing that is increasing the price of turkeys was the formation of the lieutucky Turkey Association, in 1906, with headquarter's at Lexington. This is composed of about fifty of the largest dealers in turkeys in the souther" "turkey country." a single one of whom handles more than 250,000 each Thanksgiving season and the smallest one of whom handles 65,000 pounds each fall. from meagre proportions the turkey industry has grown to such size in the country around Lexington that 4,000,000 pounds of the birds were contracted for to supply the holiday trade in 1906. Dressing in Kentucky for the 'Thanksgiving' demand was begun November 10, and and during the year of 1906 disposed of the entire lot to Armour \& Co., of Chicago. The association also tries to fix the price to be given the farmers, a frank admission of this fact being made in this statemeut after the meeting:

"The association met also to set the price that the buyers should pay for the turkeys. Nothing definite was given out, but the principal line of talk was that the farmers would be paid 10 cents a pound, live weight. With a stronger demand this might be increased to 11 cents in the conntry, which would mean about 12 or 13 cents at the pens (the points where the turkeys are confined until they are shipped alive or are dressed.)"

The farmer gets it in the neck every time, even from the "turkey trust." Oklahoma is coming to the front as a turkey raising state, the crop of 1907 amounting to 5,000 head, fur most of which the farmers got 12 to 13 cents a pound, live weight.

"Poor stock is what keeps the market down on all kinds of poultry, but especially on turkeys," said Mr. Seibels. "If a shipper sends a lot of poor birds in with a large shipment of extra tine ones, the whole consignment will bring 2 or 3 cents a pound less than it would if he lad kept the bad stuff at home. Dealers lay stress on the point that only good stock would be marketed, and agree that it is best to keep the poor, stringy birds in the country and fatten them up until they are fit to appear in the best niarkets and meet the highest class demand. Mlost of the regular shippers know this and act accordingly, but some lose their better judgment and send stock that has no business being shipped.

\section{LIVE POLLTRY PREFERRED}

"The whole poultry business is being revolutionized, I believe, by the present cold storage trouble. Within a short time, present indications are, the bulk of the poultry sent to market will be shipped alive and will be bought alive lyy the butchers, who will kill the birds to order thus proving to the customer that they have not been in cold storage. Oving to fear that the city health commissioner, Dr. Charles J. IThalen, woul, cause trouble for them, few of the dealers put turkeys in storage this 
year, and as a result nearly all the stock sold for the Thanksgiving market came directly from the farms."

1 commission of 5 cents on the dollar is charged by dealers in almost every city for selling stock for country shippers, and if the birds are scnt alive a charge of 10 cents a crate is made for hauling them from the train to is nailed round both ends and the middle of the coop to keep the other strips from loosening.

For packing turkeys to go into cold storage or for the enstern market the style of box which is most in favor is 24 by 26 by 15 inches. This will hold twelve young toms, or six young toms and eight hens, or 16 hen tur-

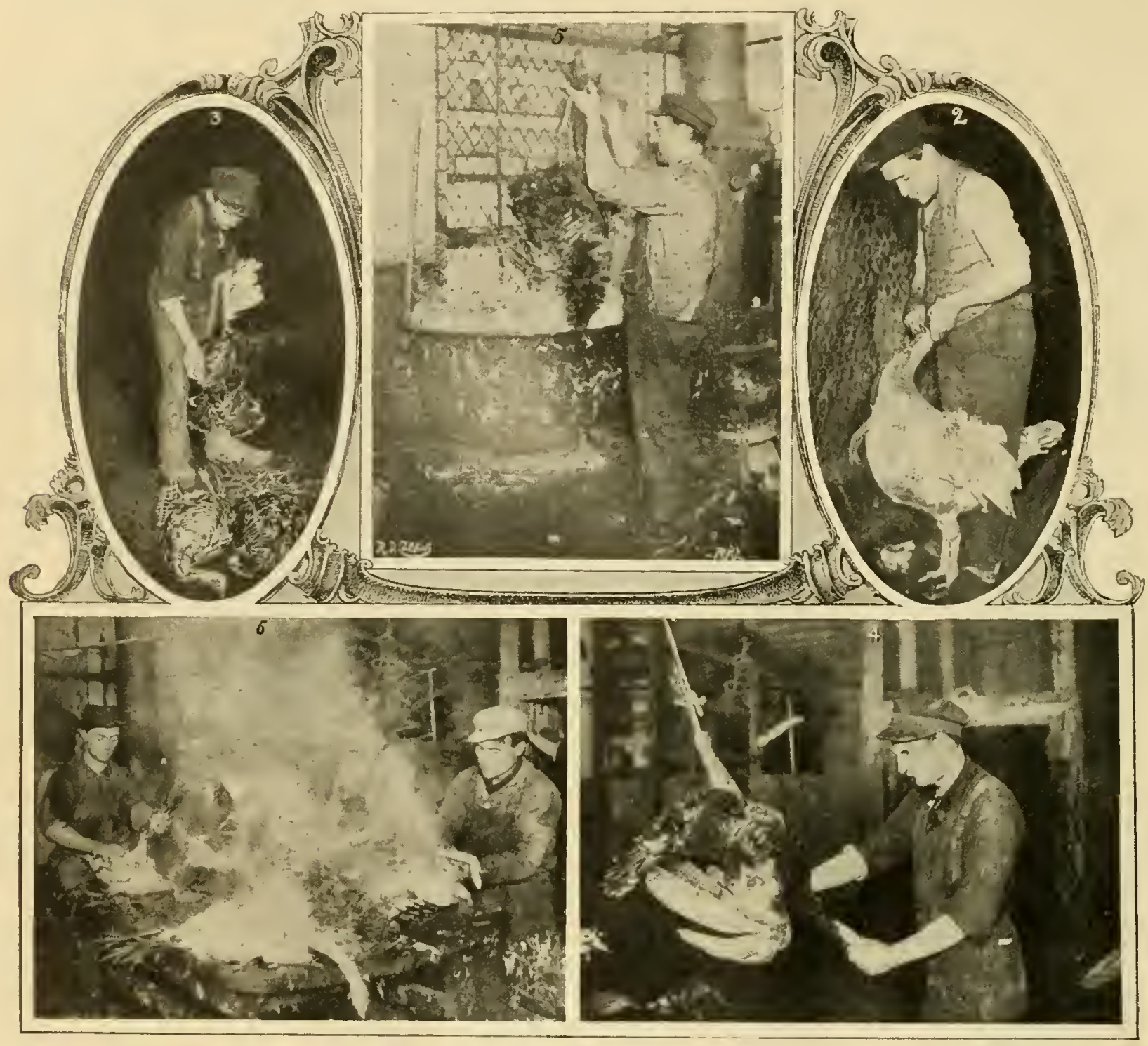

Methods of libllins and Pluching Turkeys

2-First stage in the operation of dressing. Operator holds the bird between his legs. pulls neck upward and back, and cuts a vein in the neck with a razor-edged knife. 3-Another way of killing by wringing the neck. "This to $\mathrm{t}=$ done succesfully requires a knack that comes only hy long practice. The birds wings are drawn together over 1 ts breast and the body is held between the knees. A sudden twist and jerk disiocates the neck and the fowl is dropped to the floor. 4-This operation follow's that shown in illustration 3. The dresser is dry-plucking the tur. key. Great care is required in the operation in order that the appearance of the fow 1 be not damaged. 5 Dressing a turkey by scaldung. The birds are dropped two at a truse into a metal vessel holdug a barrel of water. This method is quicker than dry-picking but destroys the value of the feathers. $6-$ The dressing tables to wlich the turkeys go after bening scalded.

the wholesale market. 'The standard ponltry coop, used in all the murkets in the country, is four feet long, 30 inches wide and a foot high for chickens and ducks, and 15 to 18 inches high for turkeys and geese. For broilers it is two feet wide and 10 inches high. The crates must be built snbstantially. Picces two inches square should be used for the corncr posts, and half inch boards should be nailed on the bottom, which is tight. strips of lath a half inch thick and two inches wide are used for the sides, top and ends, being placed an inch and a half apart. Two laths arc left loose on the top for a door, and lath lieys. The boxes should be lined with clean white or jarchment paper and the stock should be carefully yraded, and classified as No. 1, No. 2, Fancy, Culls, etc. For storing ponltry a quarter of a cent a pound is cliarged for the first sixty days or less and after that time an eighth of a cent a pound for each month. Eighty per cent of the value of the goods put in storage will be adranced to the owner by the warehouse company or by lonks.

Baby turlieys, 3 to 6 pounds each, should be marketed from Augnst 1 to Oet. 15 . 


\section{PLUCKING AN1) DLESSING}

The pluckers of turkeys are paid high wages, some of them earning $\$ 20$ a week. Many of them are paid regular wages, but most work by the piece, getting generally 5 cents a head. There were only twenty-five women, against two or three hundred men, dressing turkeys in C. icago the season of 1907. The women are all Italian or Bohemian immigrants or negresses. Sereral years ago, Z. E. Stewart stated, it was customary to employ women altogether, but when the Poultry Pickers' union came into existence it issued a dictum against it and every man refused to work with a woman picker. The union's existence has ceased, but women are not wanted. As the president of the union said:

"Dressing poultry by wholesale is no fit work for any woman. Where scalding is done none of them can endure it. Standing in water all day in a room filled with steam and then going on the street in the cold is not exactly what you would call health promoting. The men al] get sick at it, and they're a pretty tough lot of fellows, too. Nobody can stick to it more than two years."

In the room where the turkey plucking was done in one of the largest plants the women wore wooden shoes to protect their feet from the water used in scalding other poultry, and their dresses and hair were corered with feathers. The women were Italians and said they were paid $\$ 14$ a week each and handle 800 chickens or 200 apiece daily, although they do not do all the work. The men, called tippers, talie off all the heary feathers and pass the fowls to the women for finishing. The latter do the "pinning," as it is called, taking off all the down and small feathers. If they find it impossible to remove a refractory feather without tearing the skin, they cut it off close with a razor-edged knife. For pinning a dry picked turliey the cmployees get 3 cents each, and of ten finish 1 no in a day. For pinning a chicken, if they are not working by the week, they get $1 \frac{1}{2}$ cents each.

\title{
KILLING, PLUCKING AND MARKETING TURKEYS
}

\author{
The Money Value of Attractive Appearance in Market-Manner of Killing and Plucking-Saving the Feathers for an Added Profit- \\ Cooling and Cleaning the Carcass-Packing for Shipment to Dealers-Dressing and Packing for the Family Trade- \\ High Prices Obtained from Private Customers-Advantage of Knowing the Market
}

\section{H. A. NOURSE,}

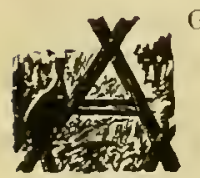

GREA'T deal depends on the manner in which turkeys are killed and prepared for market. Frequently it makes the difference in price between the highest and lowest quotations. Be the live specimen ever so fat and well fleshed. if it is carelessly picked and improperly packed it is often passed by for a bird not quite so well fattened, but presenting a better appearance when it reaches the market stalls. Obviously no producer can afford to send to market any bird that is not in good condition.

It is not difficult to properly fesh and fatten healthy turkeys. If they can be confined in a covered pen of good size, without becoming worried and losing their appetites, they will take on the most flesh, for the grain fed, in the shortest time. But young ones that have been accustomed to a wild life mpon a large range do not take kindly to confinement and can seldom be improved if enclosed.

As the supply of bugs and other food gets short in the fields the old hens will lead the young birds to the feeder and a good ration of whole corn each day for two or three weeks will put them in good flesh, with sufficient fat to give the meat and skin a bright, attractive appearance.

There is a flavor belonging to the meat of a range fed and fattened turkey that cannot be found in onc raised in confinement or one that has spent its days near the buildings eating with the chickens. The diet of grass, roots and berries not only produces flesh it less cost per pound, but improves the quality.

Before killing, the stock should be kept for eighteen hours in a clean, airy place where no food can be obtained. Tliey may have water up to within eight hours of the time of killing, for water gives a liealthy look to the slsin and assists in cleansing the digestive organs of matter which would become sour and taint the flesh. I short, stout club, a long, sharp steel blade, a strong arm and a quick hand are required for the operation of killing.

THE MANNER OF KILLING AND PLUCKING

The bird should be suspended head downward with its feet in a noose of strong cord, far enough from the walls of the house and other objects so that it cannot injure its wings when it struggles-as most of them do at some time. After stumning by dealing a sharp blow at tlie base of the skull with the club, pass the left arm around the body of the fowl under the wings, which usually drop down when the bird is stunned and the muscles relax, holding the side of the breast towards you. Grasp the head in the left hand and forcing the bill open with the thumb and fore fingers, thrust the knife blade in through the mouth to just back of the brain and make a sharp cut directly across the roof of the mouth, severing the arteries. Then holding the bird firmly with the left arm and hand in the same position, hegin at once to remove the feathers with the right hand, beginning at the juncture of neck and breast and working up over the breast and body, then giving the lird a turn which presents the back to the operator, begin at the neck or between the wings and pluck towards the tail. The short feather's of wings, tail, shanlis and neck are picked next and the long feathers of the wings and tail, if remored at all, are plucked last. As a rule the feathers of the last joint of each wing are left on and are much appreciated by the purchaser of the bird to use alout the kitchen in place of bruslies. The long feather's of the tail are removed or not as the market for which they are intended requires.

While the skin of a tmokey is less likely to be torn when removing the feathers than that of a chicken or duck, it is needful to be careful and none but experiencel pickers can safely attempt to hurry the work. The thumb and forefinger do most of the work by filmly 
grasping a few feathers and removing them by a quick jerk which begins upward toward the tail and terminates outward, which morement is accomplished by a quick twist of the wrist. This motion first loosens the feathers in their sockets by starting them the way they grow and then removes them at an angle which is least likely to tear the skin.

A well grown turkey is very powerful and requires to be held fimly yet with due care, for if the wings are

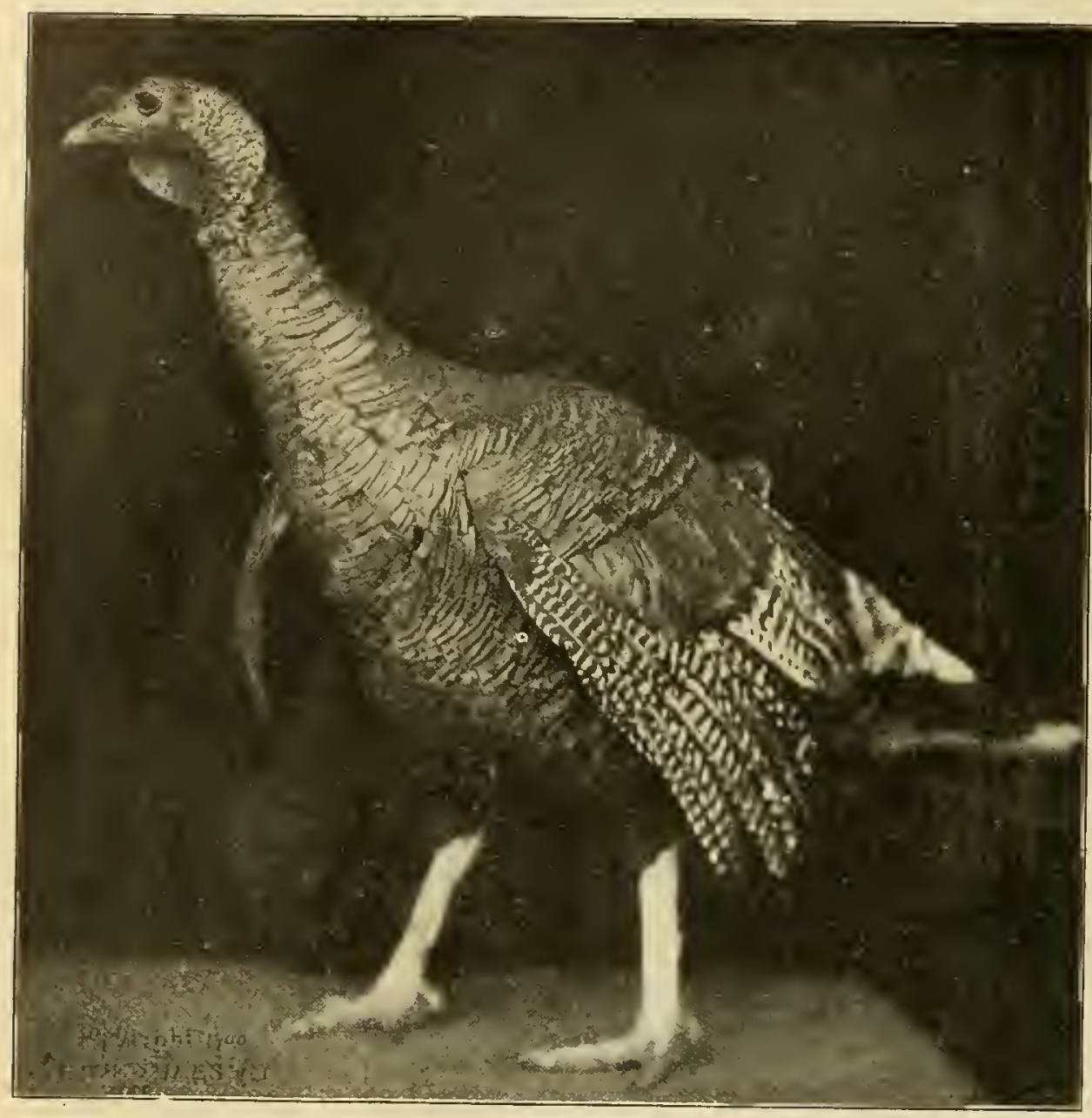

Mokinley

A Superb Bronze Turkey, that was sent to President Mckinley by Horace Vose, who for more than thirty-five years has each season presented the President of the I'nited States with a Thanksgiving Turkey. temperature is low.
COOLING AND CLEANING THE CARCASS

Narketing is usually done in the cold weather of late tall and during the winter the cooling can be done by hanging the picked turkeys in the open air, ont of the sun, long enough to allow the escape of all animal heat, but not long enough to freeze or become stiff if the

Most markets do not require the turkeys to be drawn, while some will pay less per pound for stock so prepared. It is always best to find what your market wants before killing, for if drawn turkeys are shipped where undrawn stock is wanted the loss on a consignment is considerable. Feet and heads should be washed clean and wiped dry and all blood removed from the mouth and throat. If care is used when killing and handing it will not he necessary to wash the body of the bird and the skin will retain its bright, yellow appearance longer than it would if clampened or if cooled in water rather than by the air.

\section{I'ACKING TO SIII'}

Pneking is as important an operation as picking, but not so tedious. All consignments shonld be packed tightly, not jammed, in clean boxes and suffieient packing put in before the corer is nailed on to prevent shifting emronte. Birds of different sizes, but not of different qualities, may be packed in the same box and the contents of the package should be correctly deseribed on the outside of the cover. If the deseription says "Ten young toms and ten young liens" and the dealer, on opening grasped by their extrenities or are held tou firmly in any position the bird may struggle and break or wrench them out of joint, making the carcass unfit for sale.

Careful handling after picking is rery desirable, for a bruise will cause discoloration which is very detrimental to the appearance of the flesh in marliet.

\section{SAVING THE FEATHERS}

If many birds are killed it pays to sare the feathers, especially those of the tail and wings. Those of the tail proper and the two lower joints of the wings are salnble at fifteen to thirty cents per pound and can be saved by no more extrn labor than is required to toss them into a clean receptacle when picking and later dry them by spreading upon the floor of a loft where there is a good circulation of air. 'The shorter and boly feathers selflom eommand more than 4 to 6 cents per pound and most turkey men do not eare to save them for so little remuneration. the box finds one old tom and perhaps some old hens, The of conrse loses confidence in the shipper and does not dare 10 recommend his goods. But if the contents of the paekage nerer fail to tally with the description the goods are satisfictory to handle and the returns as a rule are better. Large boxes are inconrenient to handle and less desired by small dealers than boxes weighing from one lmndred and fifty to two hundred pounds and the smaller packages reruire to be packed less solidly and the contents show less evidence of hard pressure in the box. If the market catered to favors drawn stock it is easiest done before the bird is hung up to cool. The incision made should be as small as possible. A sharp linife should be used to eut the slin close around the vent and eut away the fat around the intestine, making an opening into the calvity.

Through this the entrails must be drawn earefnlly. the operator reaching with his fingels into the earity to 
free the upper end from its attachment. Nothing else need be remored.

\section{DRESSING AND PACKING WOR I'RIVATE TRADE}

If the stock is intended for a high price family trade. all the birds should be picked and handied with extreme eare, the intestines drawn and the shanks and feet and the head removed. When cutting off the heads comsiderable blood will frequently be foumd clotted in the neck and unless removed it will turn black ancl show through the skin. If it happens that there is any food left in the crop it is wise to remove it before eooling. This is aceomplished by pushing bark the skin of the neck and working the erop out under it with the thumb and fore finger, takin! eare not to tear the crop in sepalating it from the tissues surromuling it. Removing the erop does not leave the breast looking quite so well as when the crop is enpty and left in because its absener allows the skin to sink deeper iu front of the breast bone: but if the food remains it will show black through the shin and mal the appearance of the bird. The slin should be drawn well nver the end of the neek and tied with a clean string. Each earcass when thoroughly co oled should le wrapped in clean wrapping paper. and packed in excelsior in a clean. new wooden box to be shipped to the consumer's kitehen door. I'ilper without mueh color should be user or at the end of the journey the color will be found to hase deserted the paper to eling to the shin of the turkey, which will give it more the appearance of the "tattoned man" in a circus than that of the mainstay of a family feast.

The family trade is usually rery profitable, paying well for the extra labur and other expense involved. One establishment, noted for the show room quality of it: turleys, las been furnishing private customers in ser aril states with Thanksgiving and rhristmas turkeys of the finest grade for several years. These are prepared and shipped in the manner rleseribed alhore, the weight is taken as soon as the feathers are off and the bills for them call for thirty-five cents a pound. Xo exceptional ability is needed to figure that there is money earned by properly growing and fattening. and carefully picking, packing and shipping turkeys at that price.

\section{FIN]SH TLLLING A'T NEW YEAR'S}

It is well to kill all stock unsalahle for breeding ol exhibition at $a$ before the New Year. Oecasimally, howerer, the poutryman will be caught with a few rery late hateherl punts presented by some wily old hen that hicl her nest so well and was so eautious in her "comingm: and goings" that it was not diseoverel until she brought off a browl antrary to her owner's wishes and int'ntions. Some breserlers lill these late hatched mes on sight. believing that it is nothing but time wasterl to look after thenl, (thers allow them 10 run with the hen nutil cold weatler and then house them with the chickpns. griving them the same care. They appear to do better when confined in cold weather than in warm, but

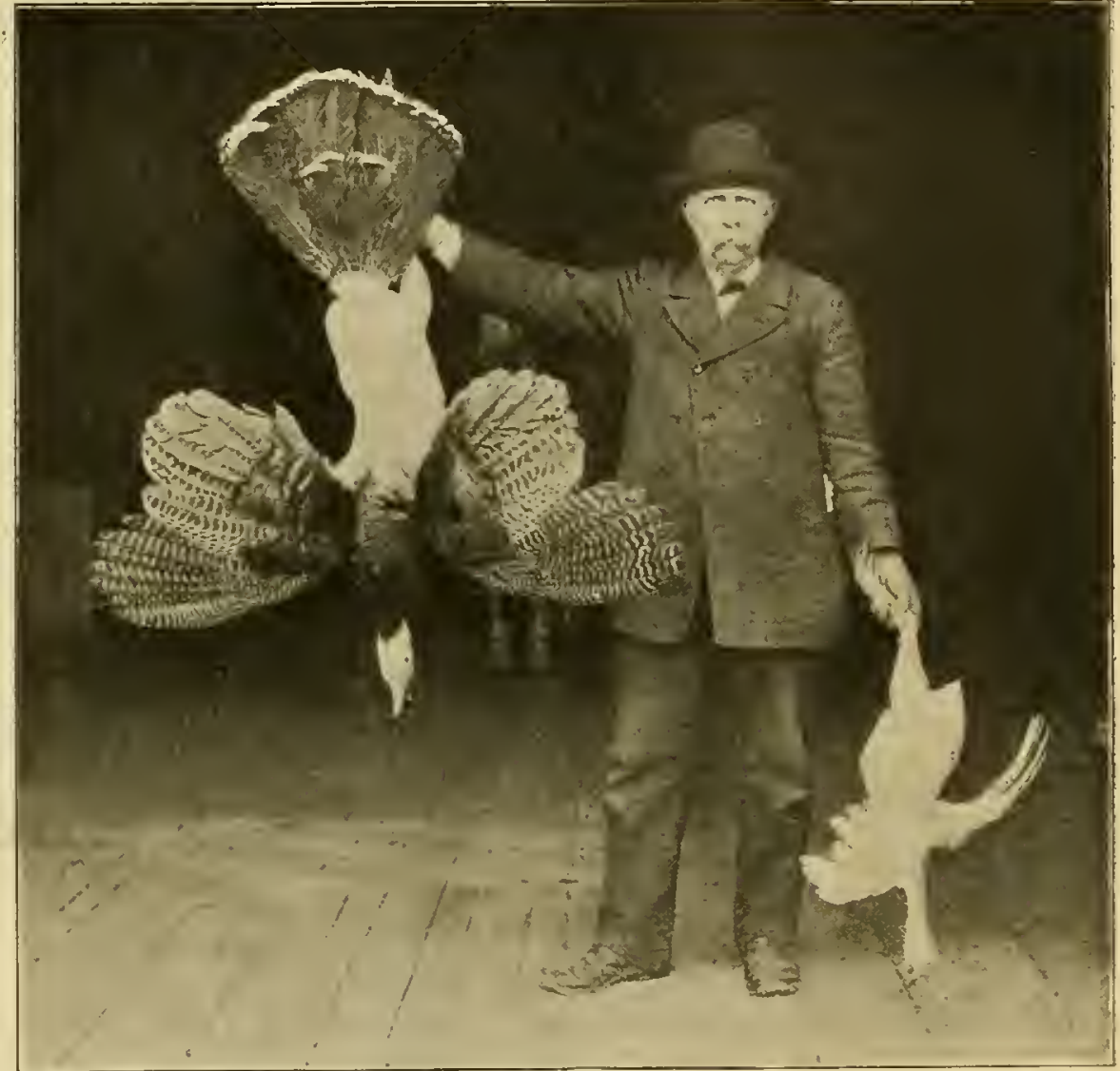

The Thankediving Turkey

Illustrated on the opposite page, dressed and ready for shipment to President Mckinley. Mr. Vose, the assist in halauciug the weight of the larger one. them sepm to hreesl live faster than chicks and must be contimully Ansted tor borly liee and their heads and neelis creased fropuntly to diseourage the head lice. If the youmsters take kindly to confinement they will make rels groul wowth and seli readily in the spring to the trad, calling for sunil sized turkeys. "These birds should never he lint for breeding, for they seldom make very strong binds and do not molt in the proper season.

Every turlisy misel who malkets any consicierable number cach rear can well afford to study his market closely; to tind just what it wants and when it will pay most for it, and then bend his energies to furnishing the right strels at the right time.

Iarketiun olitan determines the protit. 


\title{
CATCHING, HANDLING, AND SHIPPING TURKEYS
}

\author{
Bullding a Trapping Pen for Separation of the Flock-Using the Catehing Net-Training for Exhibition-Coops \\ for Local and Foreign Shipments
}

\section{H. A. NOURSE}

1 IS wise to separate from the flock in the fall the birds intended for sale, as constant raiding of the flock for birds to ship not only keeps the breeders wild and suspicious, but malies it extremely difficult to make an intelligent selection.

The best device for "rounding up" that I have seen is a covered yard or trap about thirty feet long and twenty feet wide. Sometimes this may be built between two of the farm buildings, using the buildings for the two sides, thus avoiding the necessity of setting posts and erecting sides of the enclosure. The poultry netting which forms the top and one end of the trap may be stretched between the buildings and fastened to them, supported by several pieces of heavy single wire drawn tightly from one building to the other. The other end, which is the entrance to the trap, is left open and prolided with a drop which will be described later. The turkeys will not distrust the farm buildings and will more readily enter a trap between them than one separate from them. A wing should be constructed of poultry netting five feet high to extend from one corner of the entrance to a distance of fifty feet outward or away from the trap. to form an extension of the side, unless oue of the buildings happens to be so extended. 'The turkeys may be driven gently along the side of the building towards the entrance and wing, and an occasional handful of corn may be thrown down to occupy their attention until they are at the entrance to the trap. Here the wing on the far side of the entrance prevents them going beyond and they may be quickly turned into the enclosure.

Constructing a trap in an open lot with no building is quite different. Four strong posts should be set up to form the corners of a space say thirty feet long and twenty feet wide and no other wood should be used. The posts may well be old ones, or those not carefully trimmed, and with the bark left on, so that there will be little about them to attract attention and arouse the turkeys' suspicions. It is not best to use bright wire or to turn up much earth for the same reason. The posts should stand five feet ahove the ground and have a heavy single wire like stock fence wire, stretched around their tops and also diagonally across the tops from corner to corner to support the wire netting which is stretched over it in forming the top of the trap. More netting is stretched around the sides and one end. This is tightly wired to the top and its lower edge is firmly pegged to the ground. One end is left open to serve as an entrance and is rigged with a drop. A piece of netting large enough to cover the open end is looscly wired to the strand of heary stock fence at the top of the entrance. At the opposite side of this netting, which reaches to the ground, a heary cord is attached, put through pulleys at the base of the entrance posts and carried to a distance of sixty or seventy-five feet dilectly in front of the entrance. By pulling these cords the drop will be liauled from a position on top of the trap down over the front, closing the entrance. Two wings will be required for this trap, for there is no building to assist in guiding the turkeys in. These wings, or leaders, as fishermen would call them, should extend from each side of the entrance, spreading laterally to form a sort of funnel into the large end of which the turkey's may be toled and then driven into the trap.

The posts supporting the structure must be set deeply in the ground and all the wire stretched very tightly or it will be pressed out of shape by the flock running against it when trying to get out. Sometimes the trap may be built in a grove of trees and the trunks of trees used in place of posts, at the same time securing the benefit of the branches and possible low brush as a screen to partially hide the trap. If it is convenient the turkeys should be given their daily allowance of grain in this pen and when it is necessary to handle them the drop can be closed and the flock confined, thus avoiding the necessity of driving them in; but if they are trapped too often they will not go in, and cannot be lriven or coaxed. Three times in a season should be enough to do all the selecting necessary.

\section{CATCH1NG TIIE J:1RDS}

For the actual capture a net of heary twine eighteen inches deep hung on a stout iron ring eighteen inches in diameter, which is attached to a handle seven or eight feet long, is the best contrivance $I$ know of. This if put suddenly over the head of the bird and quickly drawn back will hold it so securely that it cannot struggle and damage its feathers. Always grasp the turkey by the shanks. If by mistake you talse hold of the thigh almost every feather will be stripped off. After obtaining a firm hold, guickly remove the net and swing the bird clear of all objects until it stops struggling; then, retaining the hold on the shanks, take the turkey under one arm in such a way that its wings will be held tightly against its sides. This has no application when the bird is tame enough to be easily handled, which, however, is not often the case with turkeys on wide range.

\section{PREI'AIRING FOR EXHIBITION}

The preparation of the turkey for the show room consists principally in taming and training the subject to appear to the best adrantage in the coop. If the birds are wild it requires some days to teach them to pose. For this purpose large coops covered with canvas, or in some manner constructed so that the hird cannot cut or bruise its head trying to get ont, should be provided in a light, well rentilated room, without drafts, where the temperature langes but few degrees higher than outsicle.

Fronts of strong slats or rods having no sharp edges or rough surfaces, witl doors of generous size, are better than those of wire because they offer more chance to make friends of the birds confined and less opportunity for the oceupants to injure themselves by dashing against it, as they frequently do when introduced. A little patient work with the birds will win their confidence, but the attendant should be careful not to frighten them when feeding or when cleaning the coops or the good work will be undone. If the specimen will allow the handler to turn it around in the coop. with the 
hand or judging stick, without becoming nervous and retreating to the far colner of the cage, it is fairly well trained and will show for what it is worth under the judge. Too long confinement tires the bird and detracts from its appearance, if it cloes not make it actually sick. The wisdom of this coop training is evident to any one who has studied the turkey exhibit at the large shows. Frequently a bird is so frightened at any person apIroaching the coop that it will crouch in a corner or lash against the top of the cage, making it practically impossible to faily estimate its quality. Young toms are more prone to nervousness than females or old toms.

\section{COOPING FOR TRANSPORTATION}

Coops for shipping to exhibitions should be large enough to allow the bird to stand upright, without rubljing its head against the top, and either so narrow that the occupant cannot turn around or wide enough so that it can turn without breaking its tail. I believe in the wider coop, for it is less likely to damage the plumage by constant friction. Coops for this purpose can be used season after season and should be solidly constructed of three-eighths inch lumber over frames of inch squarc stuff; it need not be heavy, but it must be strong. The top may be hinged and prorided with hasp and staple to he hooked or locked. Ventilation may be provided in the back of the cover by an open space one inch widc and as long as the coop, and another space of equal size along the front of the coop two or three inches below the top. These will admit plenty of air for birds shipped in cool weather, will not make a draft and the turkey cannot get its liead out and get hurt. Handles conveniently placed should be on all large coops of this kind to facilitate handling by the expressmen and in a measure protect the birds from the rough handling to which large coops not so equipped are sometimes subjected.
For shipping breeding stock to points within a few days' journey a wood coop, with solid sides and slat top for cold weather and slat sides and top for warm weather, three feet long, three ftet high and fifteen inches wide, is right for toms and large hens, and one six inches less in height and length will suffice for small hens and pullets. Coops of this size allow the birds to stretch to their full beight and they arrive in much better condition than when closely hemmed in. Shipment to long distance points and to foreign countries should be in more roomy quarters. Foreign consignments should be forwarded in coops three feet long, three feet high and three feet wide for each bird, with a little extra lengtlı added when large toms are to go in them. These coopss should be made with solid sides if they are to go ou deck when crossing the water, with a space an inch wile left for ventilation near the top of the front. but may have slatted sirles if to go below decks. The only dorr should be at the bottom of the front, just wide enough to admit the turkey turned down on its side, and should extend the leugth of the side and be hinged at the top to open ontward. Cleaning and feeding may be done through this loor with but slight chance for the turkey to escape. The water dish should be placed well up in the coop with provision made for filling it through the sicles.

Unless special arrangement is made, a bag of grain and a few heads of cabbage should be forwarded, marked the same as the coops. Very good care is accorded consigminents on hoard vessels and if the shipper supplies food and utensils he may rest assured that the caretaker will do his part. These instructions apply only to consiguments forwarded in cold or cool weather; it is not safe to attempt long distance shipments in the hot weather of midsummer.

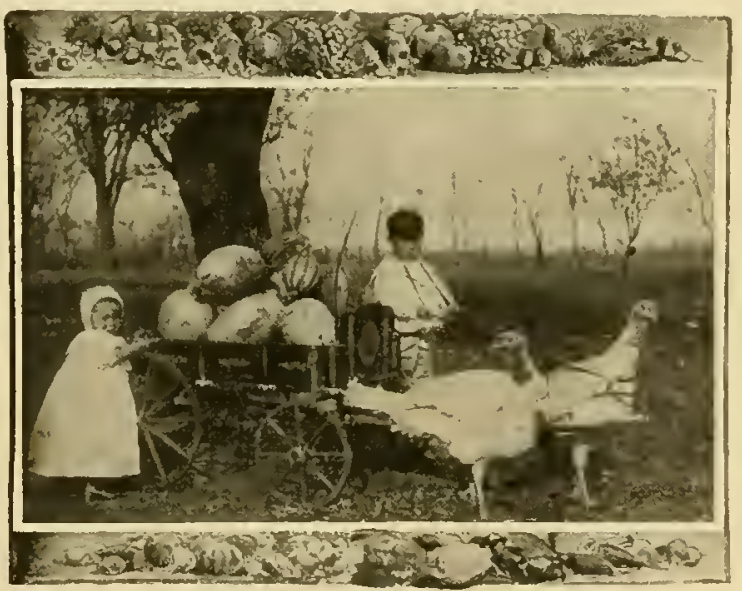




\title{
HOW TO DRY-PICK TURKEYS
}

\author{
Good Turkeys Properly Dressed Always Sell Themselves-Badly Butchered Ones Hard to Sell
}

\section{GEORGE SIXEAS}

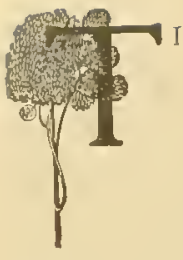

IIIS article deals with the method I use in handling dry-pieked and dry-paeked turkeys for express slipments to the easter'n city markets. I have handled as many turkeys as any one of my age and have a recold of never losing une pound of dressed poultry by spoiling in transit.

Ciond turliegs properly dressed always sell themselvesbitlly hutchereal turkeys are land to sell at atuy price.

i pen the turlieys for twelve lumrs so that their (pops will be empty; if they are killed with full erops they quiekly sour and turn black. But I do not starve the turkeys so that they will lose weight or have a gaunt look. When realy to kill, I hang the turkey by the legs in a string attached to 1he eeiling so that the turkey's hearl eomes within about four feet of the Hoor. Then I loek the turkey's wings so that one ean have better eontrol over it in sticking and pieking. To lock the wings bring one over the other and eateh the tip of the upper wing under that of the Jower. I always aim to bleed the turkeys well so that they will shorv up bright and rellow and keep long.

To stick the turkey I use a long, keen, sharp-pointed knife. I open the turkey's mouth and quiclisy plunge the knife down its throat, drawing it twice towards the bill so that I screr the jugular rein on each side of the throat, then quickly push the linife nu through the jouf of the mouth into the brain, giving the knife a slight twist. In making this thrust $I$ aim to slightly trmch the turkey's brain with the point of the knife so as to paralyze the turkey and make it loosen its hold on the feathers. If you cut too much of the brain awa it will tighten its grip on the feathers and you eannot piek it without tearing the skin. I had stuek ten thousand turkeys before I learned the art of sticling, and often in the holiday rushes when the picking gang is getting tired and their fingers are sore they have hergerl mo to do the sticking, saying that when I stick they can b]ow the feathers off.

Is soon as the turkey is stuck I hegin pulling the feathers off, and the quicker the hetter. Aim to gret the turkey picked before it is dead. The piekers are not allowed to remove a turkey from the string until it is clean, and they are nerer allowed to scrape the pin featlyers out with a knife. Is soon as the turkey is picked I plunge it into a barrel of cold water for about an hour. Then take it out of the water. eatch the turkey by the feet and hold it so that its head renches nearly io the ground. Give it a quick jerk so that the blood that has aceumulated in its throat will be jerked out. l'lace a string around its feet and hang it up to dry and eool. It is then rearly to pack for shipment as soon as it is thoroughly dry and all the animal heat has left its body.
Ten years ago most turkeys were shipured in boxes of all sizes, shapes and conditions. No attention was paid to uniformity, and second-hand shoe, hat, coffee and eanned goods and sucl other boxes as were available were used, together with burrels of varying sizes and conditions, from the little western apple barrel up to the eoffee and sugar barrels. The result of this method of packing was not altogether inviting to the eye of the buyer. Gradually more attention was given to the matter and a steady improvement has been made until at the present time boxes are made especially for the purpose. liarrels to some extent are also used at the present time, but not nearly so commonly as in year's past. The size of the parkagres has also changed. The rule used to be to get as large a box as possible, cramming in as many turkeys as it wou?d hold without splitting.

In some ways this made business good for the wholesale and jobbing houses, as there were many small dealers who were unable to handle full packages, who latd to pay an extril profit for the privilege of selecting such birds as they neerled.

Jt is a ruestion, howerer, if on the whole there was much grin to the wholesale landlers, as there were generally enough odds and ends left to serionsly detraet from the profits as a wholc. The denund for smaller packages eane to be felt by sluippers as well as wholesalers and commission men and steps were taken to supply the want. At the present time the boxes rarely weigh more thin 150 to 200 pounds each, and great numbers are packed in boxes hulling from ten to fiftecu selected birds, while it less number hold from eight to twelve. This malses it possible for' the suall marketmen and provision dealers to buy a full paekage without any extra cust for brealrage or selection, and at the same time does away with a great deal of work and with much of the rvaste whiel was prevalent in the old metlod of saeking and shipping.

The common metlod of packing birds is to make onc layer of fom turlieys in the botton of the boxes, while the upper layer is made up of temales. This gives a selection of sizes, and is better for the retailer than where they run pretty nearly one sizc throughout. The best shippers are known by their private shipping marks and it is understood just how the birds may be expeeted to turn out. Generally the case is marked so many hens, so many toms, and if any old hens or old cock birds are in the package, they are specified on the outside so that the buyer may know just exactly what he is getting. In the long run honesty in packing makes returns in dollars and eents and there is no other one thing which tells better for a shipper than a reputation for honest methods of boxing. 


\section{TABLE OF CONTENTS}

\begin{tabular}{|c|c|c|c|c|c|}
\hline Mammoth Bronze Turkeys to Date & - & - & F. L. Sewell - & \multicolumn{2}{|c|}{ Frontispiece } \\
\hline Introductory & - & - & - & - & \\
\hline How the Turkey Got Its Nane & - & - & D. E. Hale & - & - \\
\hline Turkeys and Their Management & - & - & Chas. McClave & - & \\
\hline Standard-Bred Bronze Turkeys & - & 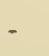 & D. E. Hale & - & \\
\hline Turkeys-Tlieir Care and Managen & uent & - & S. B. Johnstou & - & \\
\hline Successful Turkey Raising - & - & - & \multicolumn{2}{|l|}{ Mrs. M. L. Singleton } & \\
\hline Breeding Manmoth Bronze Turkey & & - & Janles F. Lord & - & \\
\hline Turkeys On Fisher's Island - & - & - & \multicolumn{2}{|c|}{ E. M. and W. Ferguson } & \\
\hline A Typical Forty-Pound Bronze Tur & rkey Cock & & Illustration & - & - \\
\hline Care and Management of Turkeys & - & - & W. J. Bell & - & \\
\hline Hatching and Rearing Bronze Turk & reys & - & Ralph S. Mosely & - & \\
\hline Some Practical Hints - & - & - & O. Fi. Skinner & - & \\
\hline Points on Turkey Breeding • & - & - & J. F. Crangle - & - & \\
\hline In Nature's Way & - & - & B. F. Ulrey - & - & \\
\hline Turkeys Raised Withont Housing & - & - & B. F. Hislop - & - & \\
\hline Mating Standard-Bred Bronze Turk & eys & - & J. T. Thompson & - & \\
\hline The Farmer's Best Friend - & - & - & Mrs. J. M. Randolph & - & \\
\hline Success With Turkeys & - & - & Mrs. Bettie Glover M & ackey & \\
\hline The Method of a Successful Breeder & & - & Mrs. H. R. Schlotzha & auer & \\
\hline The Popular Bronze Turkey & - & - & Emmet F. Pullin & - & \\
\hline Turkeys For Profit - & - & - & Mrs. Charles Jones & - & \\
\hline The Watch Word of Success & - & - & Mrs. Nellie Bullock & - & - 71 \\
\hline Down-'To-Date White Holland 'T & kes & - & Illustration & - & \\
\hline White Holland Turkeys & - & - & Jolnn R. Garbee & - & -73 \\
\hline Advocates White Holland Turkeys & - & - & J. A. Leland - & - & \\
\hline White Holland Turkeys & - & - & A. E. Biaker - & - & -76 \\
\hline Breeding White Holland Turkeys & - & - & C. C. Herron - & - & \\
\hline Raise More 'Turkeys - _ - & - & - & Mrs. W. N. Jewett & - & -78 \\
\hline Wild Turkeys & - & - & Robert Lee Blauton & - & -79 \\
\hline The Great Market Turkey - & - & - & S. 'I'. Jones & - & \\
\hline Money in 'Turkeys for the Holidays & & - & Fred Haxton - & - & \\
\hline Filling, Plucking and Marketing $\mathrm{T}$ & 'urkeys - & - & H. A. Nourse - & - & \\
\hline Catching, Handling and Shipping " & T'urkeys & & H. A. Nourse - & - & \\
\hline How to Dry Pick Turkeys - & - & - & George Sixeas & - & \\
\hline
\end{tabular}




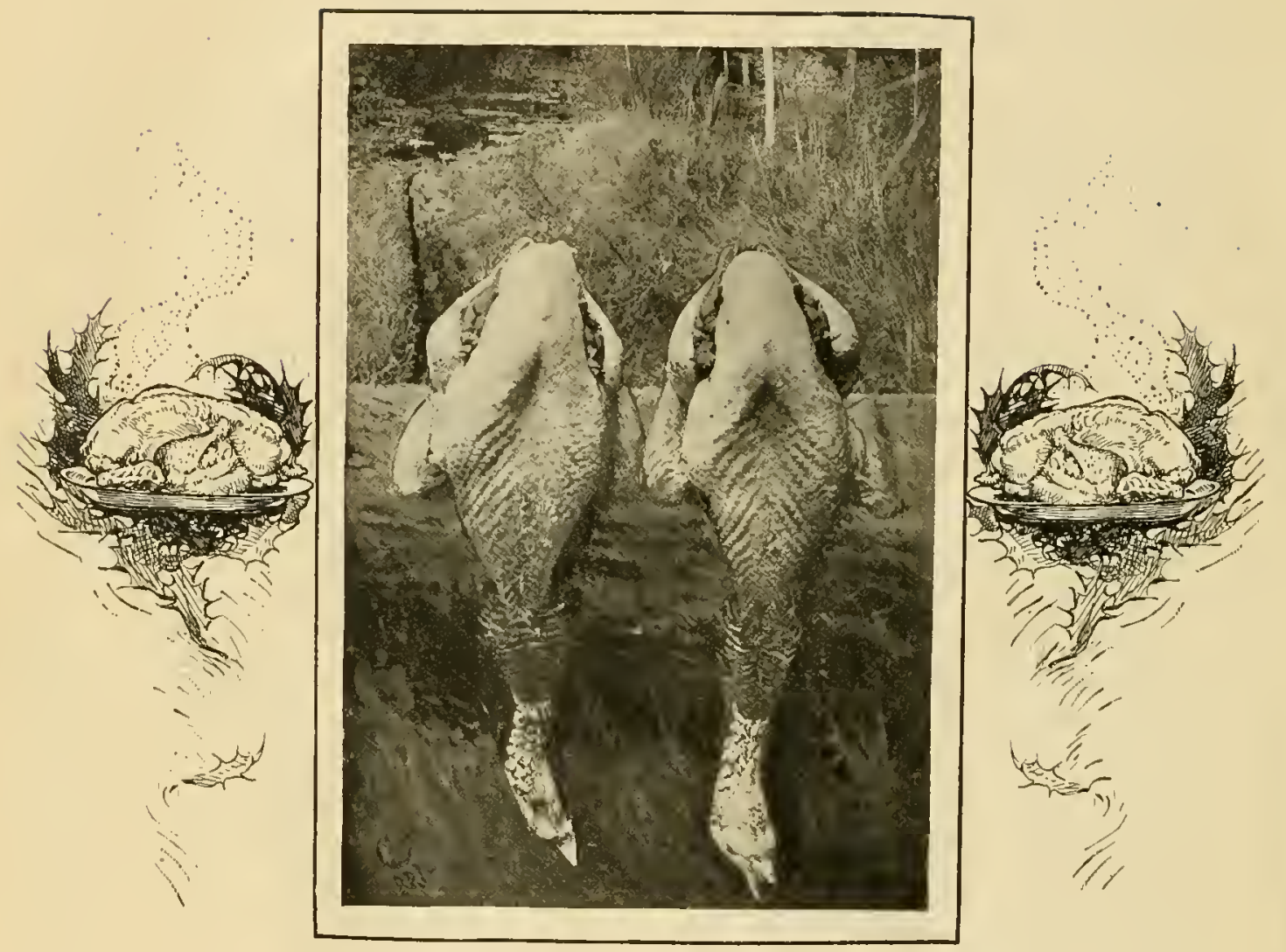

The Find 


\section{MONEY=MAKIN G POULTRY INFORMATION}

It does not make any difference how you are conducting the poultry business-on a town lot, farm or special plant-

\section{RELIABLE'S POULTRY LIBRARY}

contains valuable ideas for you. You are in danger of losing money if you do not know how the business of the most successful poultrymen is conducted, how the fowls are selected and fed to produce an extra supply of eggs during the winter, how their houses and appliances should be built, how the chickens, ducks, geese and turkeys are reared on a money-making plant of similar size to your own. All this valuable information and more is contained in the thirteen reference books of Reliable's Poultry Library.

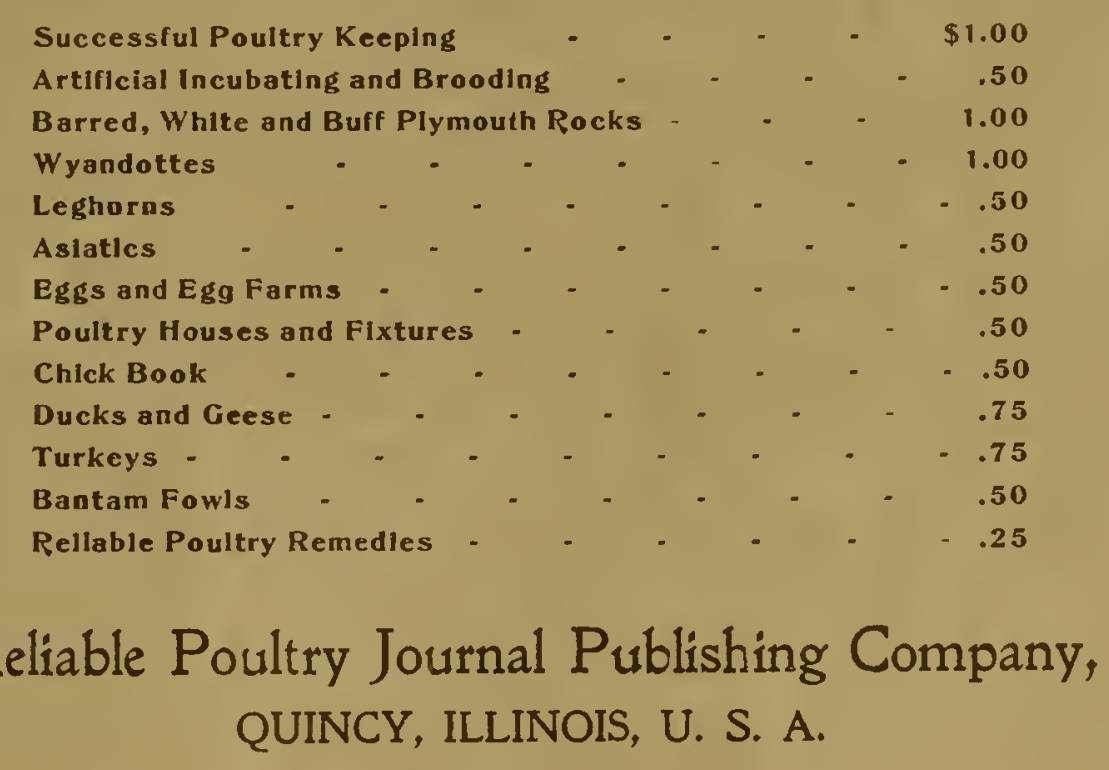


